UNIVERSIDADE DE SÃO PAULO

PROGRAMA DE PÓS GRADUAÇÃO EM ENERGIA

INSTITUTO DE ENERGIA E AMBIENTE

\title{
TALUIA CROSO
}

“Análise do planejamento setorial para o setor de gás natural: o caso do PEMAT $2022 ”$

SÃO PAULO

2015 
TALUIA CROSO

ANÁLISE DO PLANEJAMENTO SETORIAL PARA O SETOR DE GÁS NATURAL: O CASO DO PEMAT 2022

Dissertação apresentada ao programa de Pós-Graduação em Energia da Universidade de São Paulo para a obtenção do título de Mestre em Energia.

Orientadora: Prof. Dr. Hirdan Katarina de Medeiros Costa

Versão Original

SÃO PAULO

2015 
AUTORIZO A REPRODUÇÃO E DIVULGAÇÃO TOTAL OU PARCIAL DESTE TRABALHO POR QUALQUER MEIO CONVENCIONAL OU ELETRÔNICO PARA FINS DE ESTUDO E PESQUISA DESDE QUE CITADA A FONTE

FICHA CATALOGRAFICA

Croso, Taluia

Análise do planejamento setorial para o setor de gás natural: o caso do PEMAT 2022/ Taluia Croso, orientadora: Hirdan Katarina de Medeiros Costa - São Paulo, 2015

$137 \mathrm{f} .: \mathrm{il}: 30 \mathrm{~cm}$

Dissertação ( Mestrado - Programa de Pós-Graduação em Energia) IEE da Universidade de São Paulo

1. PEMAT 2022. 2. Gás Natural. 3. Planejamento 


\section{DEDICATÓRIA}

Dedico este trabalho aos meus familiares pelo apoio, auxílio e paciência. À minha mãe pela ajuda e ao Angelo e à Olívia, meus filhos, pela motivação. Também ao meu amado marido, Edmilson, por me inspirar, ensinar e ajudar durante o desenvolvimento deste estudo. E a minha amiga e orientadora Hirdan, que mostrou-se incansável em seu auxílio e compreensão. 


\section{AGRADECIMENTOS}

Agradeço a todos envolvidos direta e indiretamente nos meus estudos ao longo deste ano, meus colegas do Programa de Energia da USP, aos funcionários e professores do Instituto de Energia e Ambiente.

Em especial ao Professor Edmilson Moutinho dos Santos por ter me auxiliado desde a escolha do tema até a conclusão deste estudo, sempre enriquecendo os meus trabalhos com suas observações brilhantes.

À minha orientadora Professora Doutora Hirdan Katarina de Medeiros Costa por sua dedicação, amizade, auxílio, sem os quais seria impossível a conclusão deste trabalho.

Ao professor Doutor Murilo Tadeu Werneck Fagá pelos ensinamentos, conselhos, atenção, amizade e respeito demonstrados durante todo este tempo em que convivemos.

Ao Doutor Alberto J. Fossa pelos ensinamentos, confiança e amizade.

Ao Programa de Recursos Humanos da ANP para o Setor Petróleo e Gás - PRHANP/MCTI n.04 da Agencia Nacional do Petróleo, Gás Natural e Biocombustíveis ANP pelo suporte financeiro à minha pesquisa.

Ao Sr. Paul Poulallion pelo conhecimento compartilhado, atenção e auxílio no desenvolvimento deste estudo.

Ao Sindigás, em especial Sr. Adriano Horta Loureiro e Sr. Aurélio Antonio Ferreira pelo suporte e apoio ao desenvolvimento deste estudo acadêmico. 


\section{RESUMO}

CROSO, T. Análise do planejamento setorial para o setor de gás natural: o caso do PEMAT 2022, 2015, 136 f. Dissertação (Mestrado em Energia) - Programa de Pós Graduação em Energia da Universidade de São Paulo, São Paulo, 2015.

Este trabalho é uma análise crítica de estudo de caso do Plano de Expansão da Malha de Transporte Dutoviária (PEMAT 2022), desenvolvido pela Empresa de Pesquisa Energética (EPE), a fim de identificar as premissas e etapas da metodologia, assim como os seus resultados.

É escopo, deste estudo, apresentar críticas ao PEMAT 2022, apoiadas em revisão bibliográfica e em comparações com estudos provenientes de outras fontes de informações. Inicialmente, parte-se de uma revisão dos marcos legislativos do planejamento setorial, desde da Lei do Petróleo até a Lei do gás, que contém as diretrizes para a elaboração do PEMAT. Em termos de comparações, foram confrontadas as projeções realizadas pela EPE e adotadas no PEMAT 2022 com as projeções do Plano Decenal de Energia (PDE), também realizado pela EPE, com as de estudos internacionais; do International Energy Outlook 2013 do Departamento da Informação de Energia dos Estados Unidos (U. S. Energy Information Administration - EIA) e do World Energy Outlook 2013 da Agência Internacional de Energia (International Energy Agency - IEA). A avaliação dos resultados do PEMAT 2022 trouxe a constatação da manutenção do quadro de incipiência no que concerne à infraestrutura de gasodutos no Brasil. A partir desse cenário, propõem-se alterações necessárias para que o PEMAT, em suas futuras versões, apresente resultados mais expressivos para a expansão da malha, constituindose, assim, em um instrumento de um planejamento mais amplo, pautado em diferentes modais de transporte, que direcione incentivos para os agentes da cadeia produtiva do gás natural no Brasil.

Palavras chave: PEMAT 2022, Lei do Gás, Gás natural, Planejamento. 


\begin{abstract}
CROSO, T. Analysis of sectoral planning for the natural gas sector: the case of Pemat 2022, 2015, 136 f. Dissertation (Master in Energy) - Pos Graduate Program in Energy, University of São Paulo, São Paulo, 2015.

This paper is a critical analyis of the case study: Expansion Plan pipeline Transportation Loop (PEMAT 2022), developed by the Empresa de Pesquisas Energéticas (EPE - Energy Research Company) in order to identify the assumptions and steps of the methodology, as well as their results .

It is scope of this study, criticize the PEMAT 2022, supported by literature review and comparisons with studies from other sources of information. Initially, there is a review of legislative frameworks of sectoral planning, from the Petroleum Law to the gas law, which contains the guidelines for the preparation of PEMAT. In terms of comparisons, the projections made by EPE and adopted in PEMAT 2022 were confronted with the projections of the Ten Year Energy Plan (Plano Decenal de Energia - PDE), also conducted by the EPE and the international studies, the International Energy Outlook 2013 of the US Energy Information Administration (EIA) and also the World Energy Outlook 2013 of the International Energy Agency (IEA).

The evaluation of the results of PEMAT 2022 shows the maintaining of the incipient framework regarding the infrastructure of pipelines in Brazil. From this scenario, it proposes changes necessary for the PEMAT in future versions, present more significant results for the expansion of the grid, becoming thus an instrument of a broader planning, based on different modes of transport, direct incentives for the agents of the productive chain of natural gas in Brazil.
\end{abstract}

Keywords: PEMAT 2022, Gas Law, Natural Gas, Planning. 


\section{LISTA DE FIGURAS}

Figura 1.1 - Evolução da Malha de Gasodutos de Transporte no Brasil ......................... 18

Figura 1.2 - Malhas de Gasodutos de Transporte - Visão Comparativa........................... 18

Figura 1.3 - Projeções de Gás Natural - Plano Estratégico da Petrobrás 2030 ............... 19

Figura 2.1 - Estrutura do Mercado: A cadeia do gás natural .......................................... 25

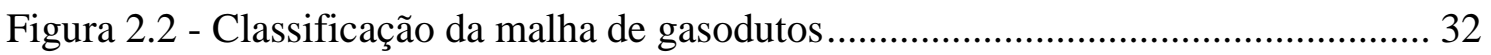

Figura 2.3 - Cadeia de valor do gás natural e do GNL ................................................. 38

Figura 2.4 - Etapas do processo de entrada de agentes no segmeto de transporte de gás

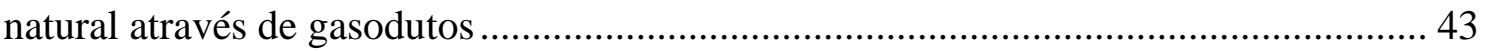

Figura 2.5 - Relações contratuais - transportador x carregador: transportador x poder

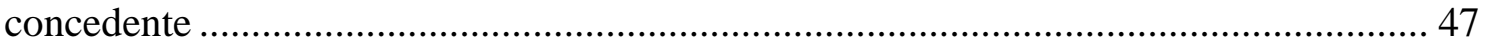

Figura 2.6 - Mapas das concessões de gás canalizado ............................................... 49

Figura 3.1 - Arcabouço Institucional da Lei do Gás...................................................... 59

Figura 3.2 - Processo de avaliação pela EPE de requerimento de provocação de terceiros

Figura 3.3 - Processos de definição das alternativas de gasodutos de transporte nos estudos

Figura 3.4 - Participação no consumo potencial de gás natural por classe

Figura 3.5 - Representação esquemática do processo de estimativa de demanda de gás

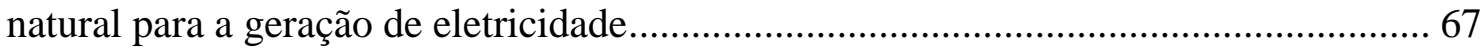

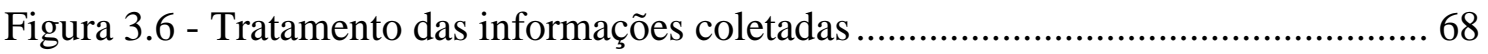

Figura 3.7 - Demanda de gás natural no sistema interligado em 2022 .......................... 69

Figura 3.8 - Esquema da definição da oferta potencial disponível de gás natural (seco)70

Figura 3.9 - Esquema da definição da produção líquida de gás natural (úmido) ........... 71

Figura 3.10 - Previsão de produção bruta potencial nacional de gás natural .................. 73

Figura 3.11 - Previsão de produção nacional de petróleo.............................................. 73

Figura 3.12 - Previsão de produção líquida potencial nacional de gás natural ............... 74

Figura 3.13 - Esquema simplificado da absorção em UPGNs ..................................... 75

Figura 3.14 - Infraestrutura de importação de gás natural no Brasil ............................. 78

Figura 3.15 - Infraestrutura existente de gasodutos de transporte no Brasil em 2012 ... 80

Figura 3.16 - Sistema de gasodutos de transporte da Região Nordeste.......................... 81

Figura 3.17 - Sistema de gasodutos de transporte da Região Sul/Sudeste/Centro-Oeste81

Figura 3.18 - Representação do Pipeline Studio de um duto e seus principais

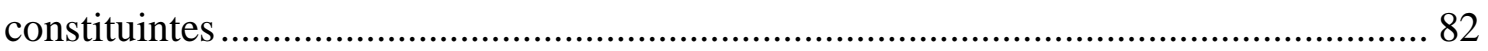

Figura 3.19 - Mapa de Unidades de conservação no Brasil .......................................... 85

Figura 3.20 - Composição do preço final de gás natural ao mercado ............................ 88

Figura 3.21 - Critérios para a tarifa de transporte estimada ........................................ 89

Figura 3.22 - Custo Médio de gasodutos no Brasil ....................................................... 93

Figura 3.23 - Custo Médio de gasodutos nos EUA em 2011-2012 ............................... 94

Figura 3.24 - Resumo do fluxo de informações envolvidas no processo de avaliação de gasodutos. 
Figura 3.25 - Alternativas estudadas de interligação de origem-destino 96

Figura 4.1 - Projeção para a produção de gás natural brasileira no cenário de referência

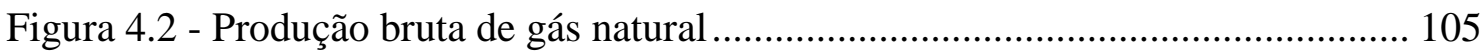

Figura 4.3 - Comparação entre as projeções de oferta de gás natural (2017 - 2022) ... 109

Figura 4.4 - Comparação entre as projeções de demanda de gás natural (2017-2022) 109

Figura 4.5 - Demanda brasileira de gás natural por setor no cenário de referência ..... 111

Figura 4.6 - Demanda brasileira de gás natural por setor no cenário de referência ..... 111

Figura 4.7 - Gasodutos na Europa .......................................................................... 115

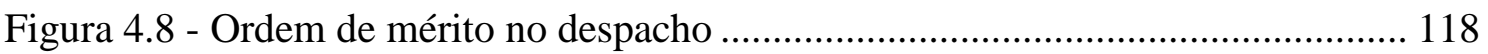

Figura 4.9 - Crescimento do consumo energético 2012/2011 .................................... 121

Figura 4.10 - Matriz de geração elétrica 2011/2013 ................................................... 122

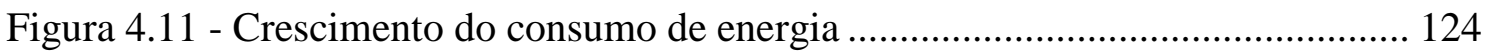

Figura 4.12 - Mercados residencial, comercial e industrial: GLP, óleos diesel e combustível, gás natural, energia elétrica industrial e residencial (R $\$ /$ bep) ................ 126

Figura 4.13 - Consumo de energia pelas famílias em 2011 ..................................... 127

Figura 4.14 - Consumo de energia pelas famílias em 2012 ....................................... 128

Figura 4.15 - Consumo de energia pelo setor industrial em 2011 ............................. 128

Figura 4.16 - Consumo de energia pelo setor industrial em 2012 ............................. 129 


\section{LISTA DE TABELAS}

Tabela 2.1 - Transportadoras de gás natural em operação no Brasil ............................... 46

Tabela 2.2 - Quadro resumo lei do petróleo versus lei do gás....................................... 50

Tabela 2.3 - Histórico da participação do gás natural na matriz energética brasileira ... 52

Tabela 2.4 - Consumo de gás natural por segmento ....................................................... 53

Tabela 2.5 - Balanço de gás natural no Brasil ................................................................ 54

Tabela 2.6 - Preços referência no Brasil - outubro/2014 ................................................. 55

Tabela 2.7 - Preços PPT .................................................................................. 55

Tabela 3.1 - Demanda potencial não termelétrica de gás natural por região geográfica e

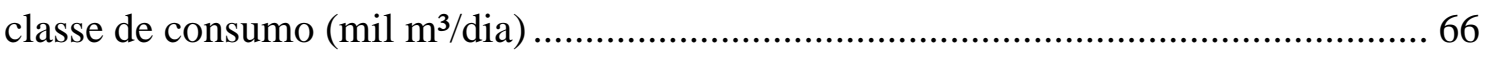

Tabela 3.2 - Demanda potencial de gás natural no sistema integrado (milhões $\mathrm{m}^{3} / \mathrm{dia}$ ) 69

Tabela 3.3 - UPGNs existentes e seus respectivos índices de rendimento...................... 77

Tabela 3.4 - Capacidade de importação por gasoduto e por GNL no horizonte do estudo

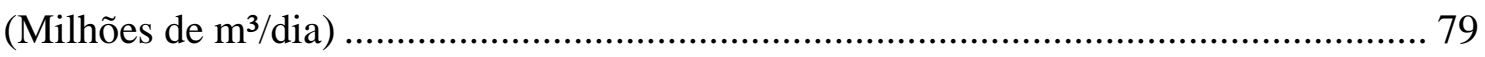

Tabela 3.5 - Operação de gasodutos de transporte por transportadora no Brasil ............ 80

Tabela 3.6 - Balanço de Demanda e Oferta potencias de gás natural no sistema

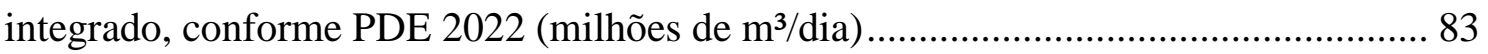

Tabela 3.7 - Preço de oferta do gás natural especificado ........................................... 90

Tabela 3.8 - Preço máximo do gás natural no citygate para cada distribuidora considerando 1005 de competitividade com o óleo combustível ................................... 90

Tabela 3.9 - Premissas adotadas pela EPE na análise econômica ................................. 91

Tabela 3.10 - Custo de capital próprio (\% ao ano), taxa de juros e custo médio

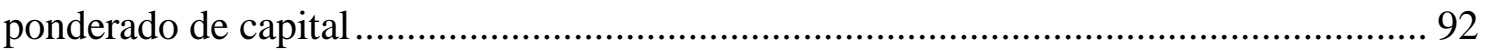

Tabela 3.11 - Caracterização básica das alternativas identificadas nos estudos do PEMAT 2022

Tabela 3.12 - Estimativas de custos de investimento e tarifas de transporte das alternativas identificadas nos estudos do PEMAT 2022 - EVTE Simplificado ............ 98

Tabela 3.13 - Análise de viabilidade técnica e econômica.......................................... 100 Tabela 3.14 - Avaliação das alternativas identificadas para aprofundamento nos estudos do PEMAT 2022 pelos critérios de balanço de oferta e demnda e tarifa de transporte -

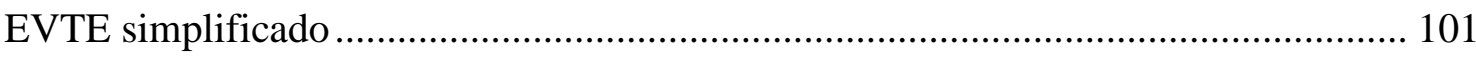

Tabela 4.1 - Projeção da oferta potencial máxima de gás natural ................................ 105 Tabela 4.2 - Projeção da oferta de gás natural no período entre 2014 e 2022 (milhões de

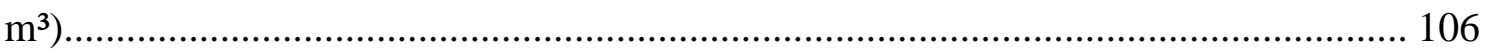

Tabela 4.3 - Projeções de demanda de gás natural (milhões de $\mathrm{m}^{3}$ )............................. 107

Tabela 4.4 - Demanda potencial não termelétrica de gás natural (milhões de m²/dia) 108

Tabela 4.5 - Demanda potencial de gás natural ( milhões de m³/dia) .......................... 108

Tabela 4.6 - Centrais elétricas de serviços públicos .................................................. 123 
1 Sumário

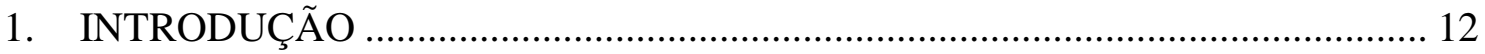

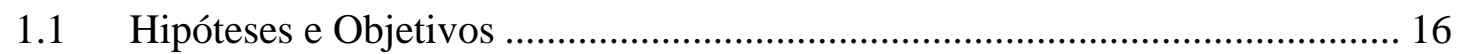

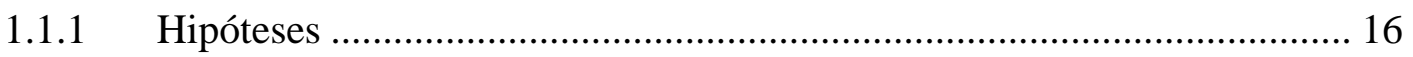

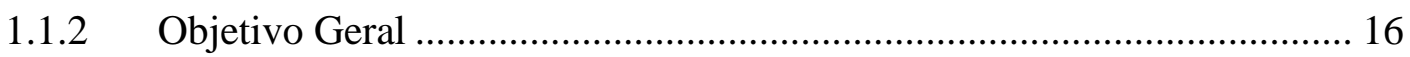

1.2 Justificativa, relevância e motivação ................................................................ 17

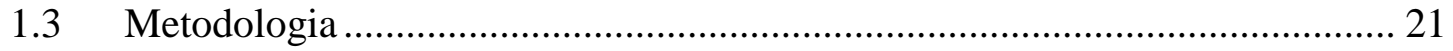

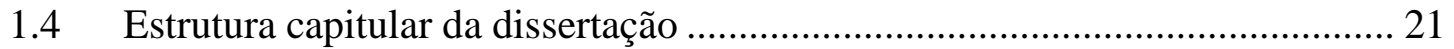

2 LEGISLAÇÃO DO SETOR DE GÁS NATURAL E O PLANEJAMENTO

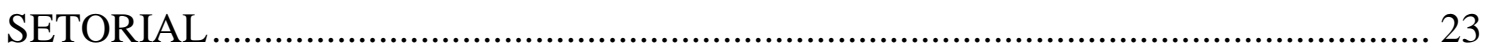

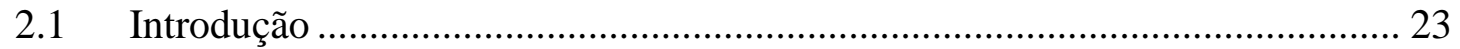

2.2 A Lei do Petróleo e o setor de gás natural ........................................................ 24

2.2.1 Dos princípios da Política Energética Nacional (PEN) .......................... 26

2.2.2 Os órgãos setoriais na Lei do Petróleo .................................................. 27

2.2.3 Do Upstream ao Downstream: o gás natural na Lei do Petróleo ............. 31

2.3 Mudança de paradigmas: projetos de Lei do Gás ............................................. 34

2.3.1 Projeto de Lei n ${ }^{\circ}$ 226/2005 e o seu substitutivo ...................................... 34

2.3.2 Projeto de Lei ${ }^{\circ}$ 6673, de 2006 - MME ................................................ 36

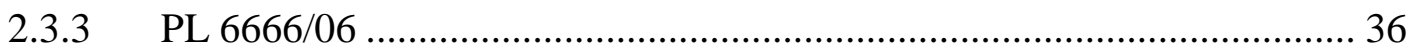

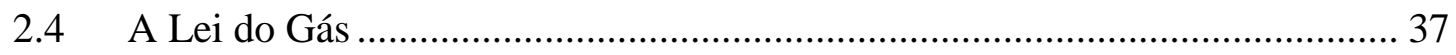

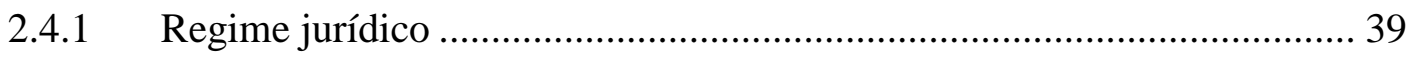

2.4.2 Funções do MME ................................................................................ 43

2.4.3 Dos agentes na Lei do Gás ................................................................ 45

2.4.4 Distribuição e comercialização............................................................. 48

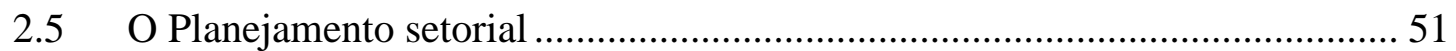

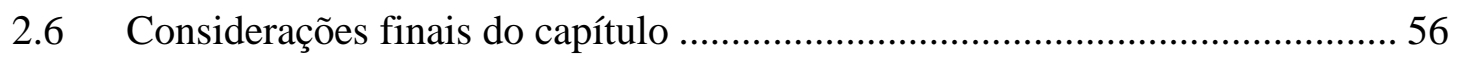

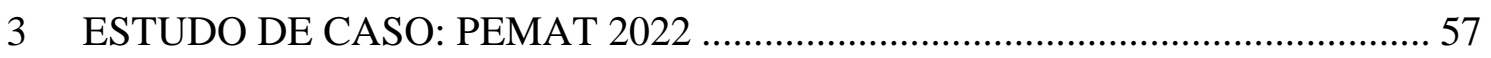

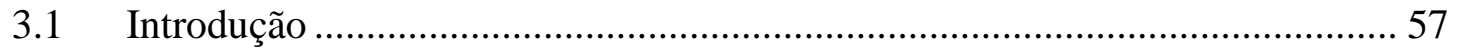

3.2 A Empresa de Pesquisa Energética (EPE) e o planejamento setorial .............. 57

3.3 Avaliação das proposições por terceiros....................................................... 59

3.4 Critérios para Avaliação de Alternativas para o PEMAT 2022 ....................... 61

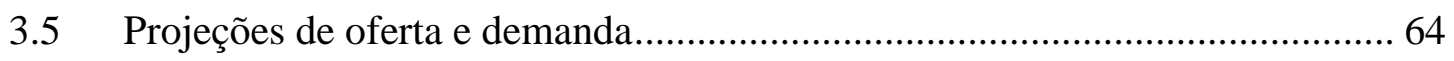

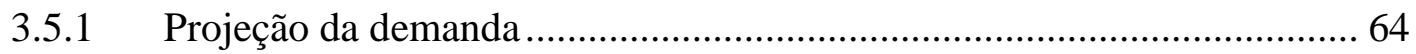

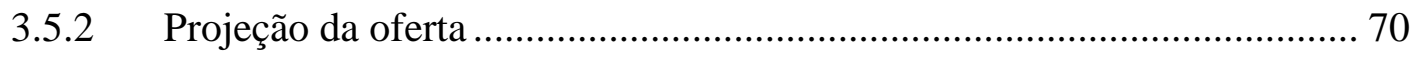


3.5.3 Balanço de demanda e oferta simulação termo-fluído-hidráulica 79

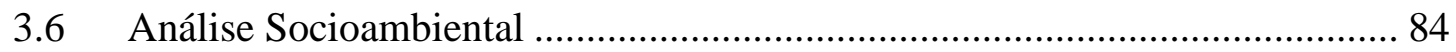

3.7 3.6 Análise técnico econômica (EVTE) simplificado e detalhado ................. 87

3.8 Análise das proposições - "resultados do PEMAT 2022” .............................. 95

3.9 Considerações finais do capítulo .................................................................. 101

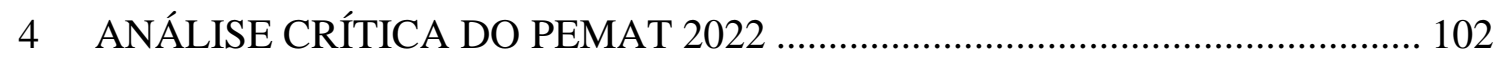

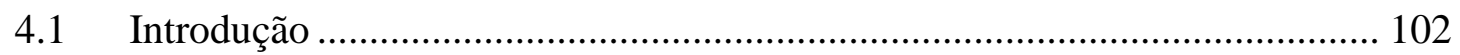

4.2 Comparativo entre as projeções de oferta e demanda do PEMAT 2022 e outros estudos

4.2.1 Projeções de oferta........................................................................... 102

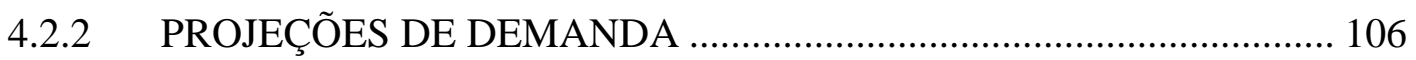

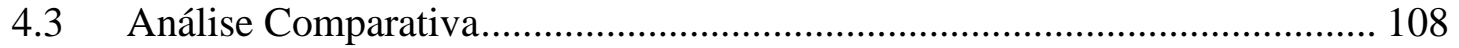

4.4 Considerações finais sobre oferta e demanda .............................................. 114

4.4.1 Oferta de gás natural e desenvolvimento de malhas............................. 114

4.4.2 A autossuficiência de gás natural ...................................................... 115

4.5 Crítica do modelo de inserção do gás existente no PEMAT 2022 ................ 117

4.6 Consumo de energia no Brasil: o crescimento da geração termelétrica a gás

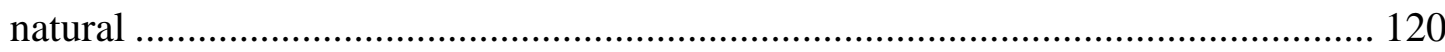

4.7 Considerações finais do capítulo e proposição de um novo modelo de planejamento para o mercado de gás natural ......................................................... 130

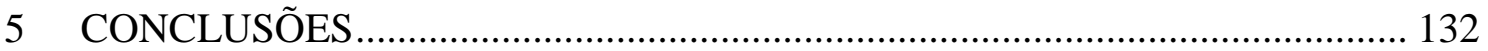

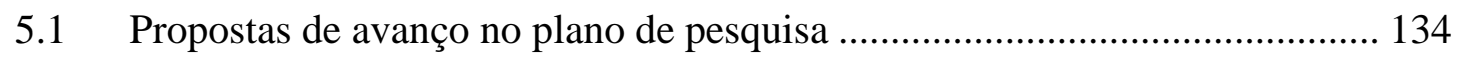

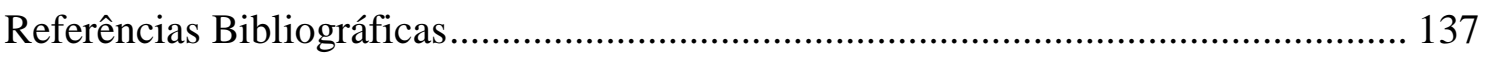

\section{INTRODUÇÃO}


O Plano Decenal de Expansão da Malha de Transporte Dutoviária (PEMAT 20132022), foi aprovado em 19 de março de 2014, depois de ter sido submetido ao processo de Audiência Pública a partir de 10 de janeiro de 2014. A concepção e aprovação desse documento de Planejamento Setorial cumpriu uma obrigação governamental sancionada em 4 de março de 2009, quando foi aprovada a Lei nº 11.909 (Lei do Gás), a qual foi regulamentada pelo Decreto $\mathrm{n}^{\circ}$ 7.382, de 2 de dezembro de 2010 (BRASIL, 2014a), (BRASIL, 2014b).

O PEMAT 2022 contém as bases para a expansão da infraestrutura de gás natural no Brasil. Como resultado do exercício de planejamento, o PEMAT 2022, nas duas primeiras linhas de sua introdução e na sua primeira nota de rodapé, estabelece como sua hipótese de trabalho que:

A indústria de gás natural se caracteriza fortemente como uma indústria de
rede, na qual ofertas e demandas devem ser conectadas por uma rede física -
no caso, a malha de gasodutos (...) as exceções são o atendimento por gás
comprimido e por gás liquefeito; alternativas que, em geral, só apresentam
competitividade em relação às fontes substitutas para o atendimento do
consumidor final em condições bem específicas. Por conta disto, a maior parte
da movimentação do gás natural é realizada por meio de gasodutos. (EPE, 2014
p.11)

Com essa hipótese de trabalho, o PEMAT 2022 foca, exclusivamente, na opção logística de gasodutos, para o transporte de gás em território nacional. E, dentre as opções sugeridas e estudadas, foram identificados, no PEMAT 2022, sete projetos, os quais totalizariam um adicional de malha de transporte de cerca de 4 mil quilômetros de extensão, incrementando a capacidade de transporte total de 32,5 milhões de $\mathrm{m}^{3} / \mathrm{dia}$ (admitindo a operação em plena carga dos sete projetos concebidos). Sempre de acordo com o PEMAT 2022, esses projetos demandariam investimentos da ordem de R $\$ 13,5$ bilhões. O projeto mais significativo entre as sete opções sugeridas seria a expansão do trecho sul do gasoduto Brasil - Bolívia, totalizando um investimento de R \$ 4,6 bilhões, para uma extensão adicional de 1,17 mil quilômetros (EPE, 2014).

Entretanto, nenhum dos projetos analisados pelo PEMAT 2022 foi considerado viável e apto para ser levado à licitação para eventual concessão a operadores públicos ou privados. Além disso, não foi identificada a disponibilidade de gás para ser transportado nos dutos ${ }^{1}$.

\footnotetext{
${ }^{1}$ O único gasoduto que foi considerado viável e que, segundo o PEMAT 2022, deverá ser licitado, é o gasoduto Itaboraí (RJ) - Guapimirim (RJ), proposto pela Petrobrás, e que fará parte do sistema de
} 
O PEMAT 2022 contém as bases para o "planejamento decenal da expansão da infraestrutura de gás natural no Brasil”. Desta forma, os resultados apresentados conduzem à conclusão de que a incipiência da infraestrutura de gasodutos no Brasil será mantida

A ausência da malha de transporte, conforme apresentado por Moutinho dos Santos et al. $(2002)^{2}$, inviabiliza o desenvolvimento dos mercados de gás e dos projetos de produção, seja em atividades offshore, seja junto a autoprodutores em áreas onshore. Portanto, o resultado final apresentado pelo PEMAT 2022 deve ser interpretado como fator limitante para o crescimento da produção de gás natural e para que este recurso esteja disponível para a sociedade. Percebe-se que o efeito direito da escassez de infraestrutura de transporte é o comprometimento dos cenários de expansão dos usos do gás no Brasil e, sobretudo, da captação desses recursos nas zonas de produção, já que o sucesso na exploração não garantirá a comercialização do gás.

Dessa forma, a presente dissertação de mestrado parte da premissa de que a aceitação pura e simples dos resultados inicialmente publicados pelo PEMAT 2022 condena a indústria do gás ao seu confinamento e à falta de escala e de competitividade. No entanto, tais resultados e o próprio PEMAT 2022, bem como suas implicações, não receberam a devida divulgação junto aos diferentes grupos de interesse, incluindo os especialistas e as autoridades governamentais, as quais, como será visto ao longo deste texto, permanecem confiantes em cenários que indicam a expansão da indústria do gás no país, mesmo com a carência de investimentos nos sistemas de logística tão necessários.

escoamento de gás natural do pré-sal da Bacia de Santos para o Comperj. Este gasoduto tem capacidade de transportar 17 milhões de metros cúbicos por dia. Contudo, este projeto não será discutido nesta dissertação, pois se considera que se trata de um projeto integrado e dedicado ao Comperj, não devendo ser tratado como uma infraestrutura independente e com potencial de compor uma logística de gás natural a suportar um mercado abrangente e de usos difusos do gás. Assume-se que, em respeito a esse gasoduto, e a tantos outros, com características similares, que, por ventura, venham a ser propostos no futuro, não se necessita de um "planejamento", conforme estabelecido pela Lei do Gás. Essas obras estão integradas dentro do planejamento de algum projeto integrado maior.

\footnotetext{
${ }^{2}$ Dentro de uma perspectiva histórica sobre Brasil, Moutinho dos Santos et al. (2002) já constatavam a dificuldade de se expandir o acesso ao gás importado da Bolívia, já que não havia uma malha de transporte e distribuição a jusante do gasoduto internacional, GASBOL. Dias (2004), então representando a Agência Nacional de Petróleo, Gás Natural e Biocombustíveis (ANP), ao discutir sobre as possibilidades de "Regulamentação do Acesso ao sistema de Transporte de Gás Natural no Brasil", reconhecia a dificuldade brasileira de se promover mercados mais pujantes e com ambientes de negócio mais competitivos, devido à ausência de infraestrutura adequada. Mais recentemente, monitorando os potenciais de desenvolvimento do "shale gas", a KPMG (2011) identifica a ausência de gasodutos como a principal barreira para que outras experiências de sucesso possam ser replicadas em regiões fora dos Estados Unidos. Ou seja, trata-se de problemática recorrente dentro do mundo do gás natural,
} 
Diante disso, pretende-se realizar uma análise crítica deste instrumento fundamental do planejamento setorial para o setor de gás natural. Esta análise crítica deve ser elaborada diante da evolução da legislação, conforme descrito ao longo do texto, pois essa traduz os princípios que têm balisado as políticas que incentivam o desenvolvimento da indústria do gás e o uso desse recurso energético no mercado brasileiro. Essa história legal resgata os princípios, relacionados ao gás natural, publicados na Lei do Petróleo ${ }^{3}$, em 1997, e chega à compreensão de como a Lei do Gás surgiu como uma solução legal para o eventual "destravamento da indústria do gás", sendo que o momento mais esperado, e, de certa forma frustrado, desse processo, foi a edição do PEMAT 2022.

Em seu olhar crítico, a autora desejou fundamentar-se em hipóteses de trabalho ainda mais abrangentes, propondo discussões alternativas basilares sobre o planejamento setorial da indústria do gás natural. Partindo das boas práticas do Planejamento Integrado de Recursos (PIR), a autora desejou incorporar novas dimensões ao Planejamento Logístico Integrado (PIL) da indústria gasífera. Uma visão multimodal desse planejamento promete gerar resultados mais interessantes, que poderão melhor adequarse aos objetivos pretendidos pelos legisladores.

No entanto, desde o início desse exercício de maior fôlego, a autora deparou-se com debates iniciais e desconhecimentos em respeito ao PEMAT 2022, os quais comprometiam, metodologicamente, a elaboração de uma análise crítica de fácil entendimento, e que pudesse ser absorvida como instrumento útil pelos diferentes grupos que têm interesse no desenvolvimento da indústria gasífera nacional.

Desta forma, com apoio de sua orientadora, a autora definiu fatiar suas reflexões e agenda acadêmica em dois momentos, os quais, individualmente, já encerram desafios próprios e relevantes, que justificam uma dissertação de mestrado e tese de doutorado. Nesta dissertação, foca-se, prioritariamente, na análise crítica do PEMAT 2022, propriamente dita. Trata-se de rever, criticamente e de forma abrangente, os princípios que regem esse instrumento de planejamento setorial. Acredita-se que tal leitura facilitará aos eventuais leitores desta dissertação compreender o PEMAT 2022 e seus principais resultados, bem como as intrincadas hipóteses que conduzem aos mesmos.

A autora transfere para um segundo momento de sua agenda de pesquisa, a ser elaborado dentro do Curso de Doutorado no Programa de Pós-Graduação em Energia do Instituto de Energia e Ambiente da Universidade de São Paulo (PPGE-IEE-USP), despir-

\footnotetext{
${ }^{3}$ LEI N ${ }^{\circ}$ 9.478, DE 6 DE AGOSTO DE 1997
} 
se das amarras conceituais e metodológicas propostas pelo PEMAT 2022, para, então, elaborar propostas alternativas (e talvez mais audazes), que possam enriquecer o planejamento setorial da indústria dos gases combustíveis no Brasil.

\subsection{Hipóteses e Objetivos}

\subsubsection{Hipóteses}

Esta dissertação parte da análise da legislação do setor de gás natural e propõe uma crítica ao planejamento setorial publicado no PEMAT 2022. Assume-se como hipótese de trabalho que os resultados apresentados no PEMAT 2022 limitam o desenvolvimento do mercado do gás natural no país.

O planejador deve, portanto, focalizar em soluções alternativas, as quais podem encontrar-se no plano dos arranjos institucionais e legais, bem como na extensão das oportunidades logísticas a serem propostas e exploradas, deixando de sinalizar tão somente projetos de infraestrutura de gasodutos.

\subsubsection{Objetivo Geral}

A dissertação propõe, como objetivo principal, a análise crítica do planejamento setorial do setor de gás natural, através do estudo de caso do PEMAT 2022. A perspectiva a se examinar é: “como os resultados advindos do plano setorial, através da metodologia adotada, pode influenciar a política governamental de desenvolvimento do mercado de gás natural no médio prazo”.

\subsubsection{Objetivos Específicos}

Entre os objetivos específicos destacam-se:

(i) Resgatar dentro da ótica do planejamento, a evolução da legislação do setor de gás natural brasileiro, desde a promulgação da Lei do Petróleo, em 1997, até a publicação da Lei do Gás, em 2009, focalizando os elementos críticos que afetam os temas associados o setor de transporte de gás natural;

(ii) Detalhar e criticar os elementos fundamentais da metodologia do PEMAT 2022, apontando as escolhas realizadas pelos técnicos governamentais e como essas conduzem aos resultados devidamente publicados; 
(iii) Examinar os dados do setor de gás natural a partir de outras fontes e confrontálos ao PEMAT 2022.

\subsection{Justificativa, relevância e motivação}

A incipiência da infraestrutura de gás natural tem sido um entrave para a oferta deste insumo nos diversos setores da economia brasileira. Mesmo em momentos de oferta abundante de gás, como ocorreu no final dos anos 1990 e início dos anos 2000, quando o gasoduto GASBOL, conectando a Bolívia ao Brasil, acabara de ser construído e ainda permanecia com elevada capacidade ociosa de transporte, os diversos usos difusos do gás natural não se desenvolveram. As carências logísticas a jusante do GASBOL impediam uma estratégia de massificação da demanda em diferentes segmentos de consumo, principalmente na substituição da eletricidade, como propagado por Moutinho dos Santos et al (2002). Assim, por exemplo, a substituição da eletricidade por usos diretos do gás teve papel insignificante entre as estratégias adotadas pelo governo da época, para reduzir os riscos ou, posteriormente, mitigar os efeitos do racionamento de eletricidade de 2001.

Apesar da expansão da malha de gasodutos no país, quase dobrando entre 2000 e 2012, principalmente em virtude do Plano de Massificação do Gás Natural, adotado pela Petrobras no período (vide Figura 1.1), há de se constatar que a logística de transporte de gás no Brasil permanece "acanhada" quando comparada com aquelas de nações com as mesmas dimensões territoriais, populacionais e econômicas (vide Figura 1.2). 


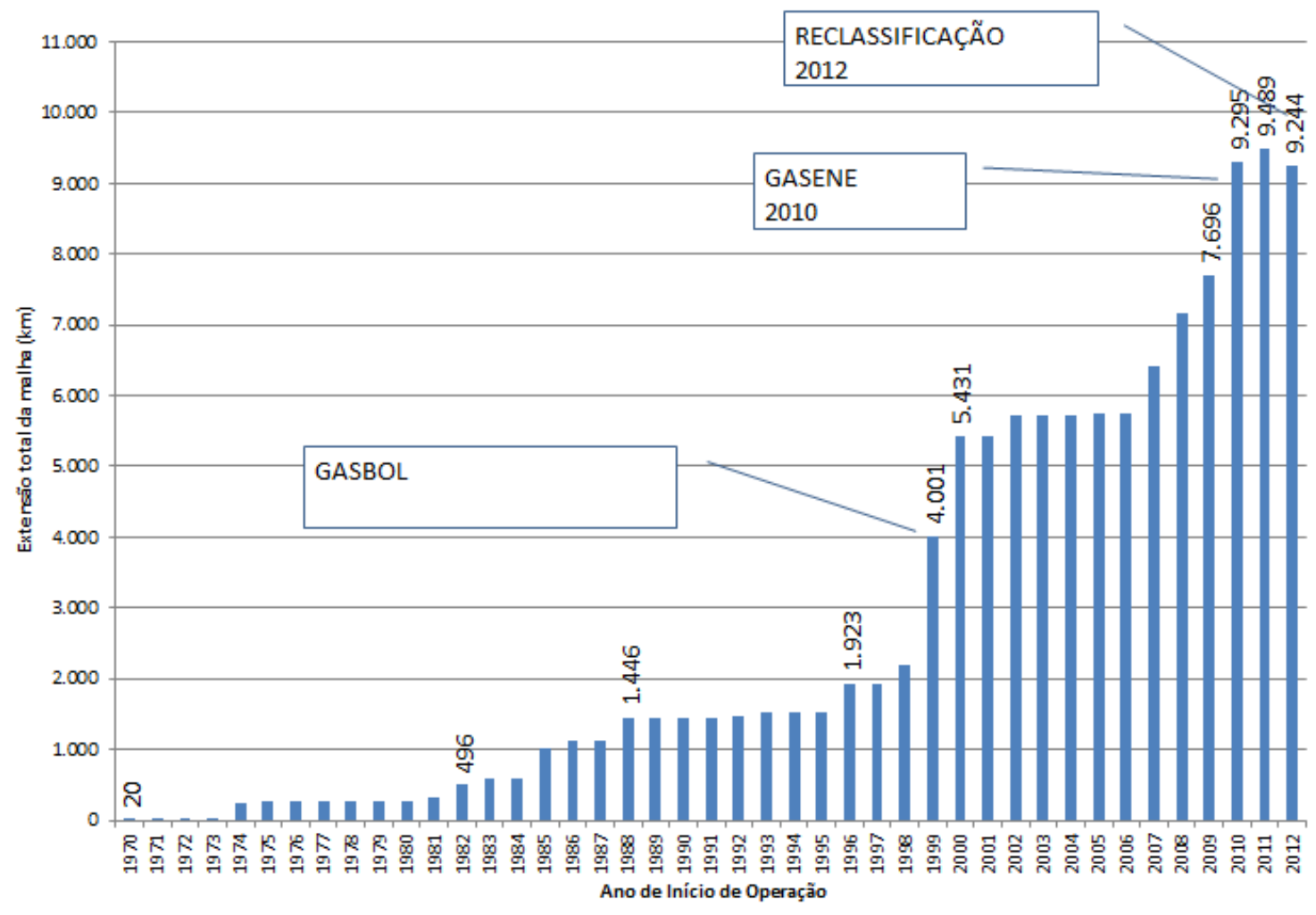

Figura 1.1 - Evolução da Malha de Gasodutos de Transporte no Brasil

Fonte: EPE (2014)

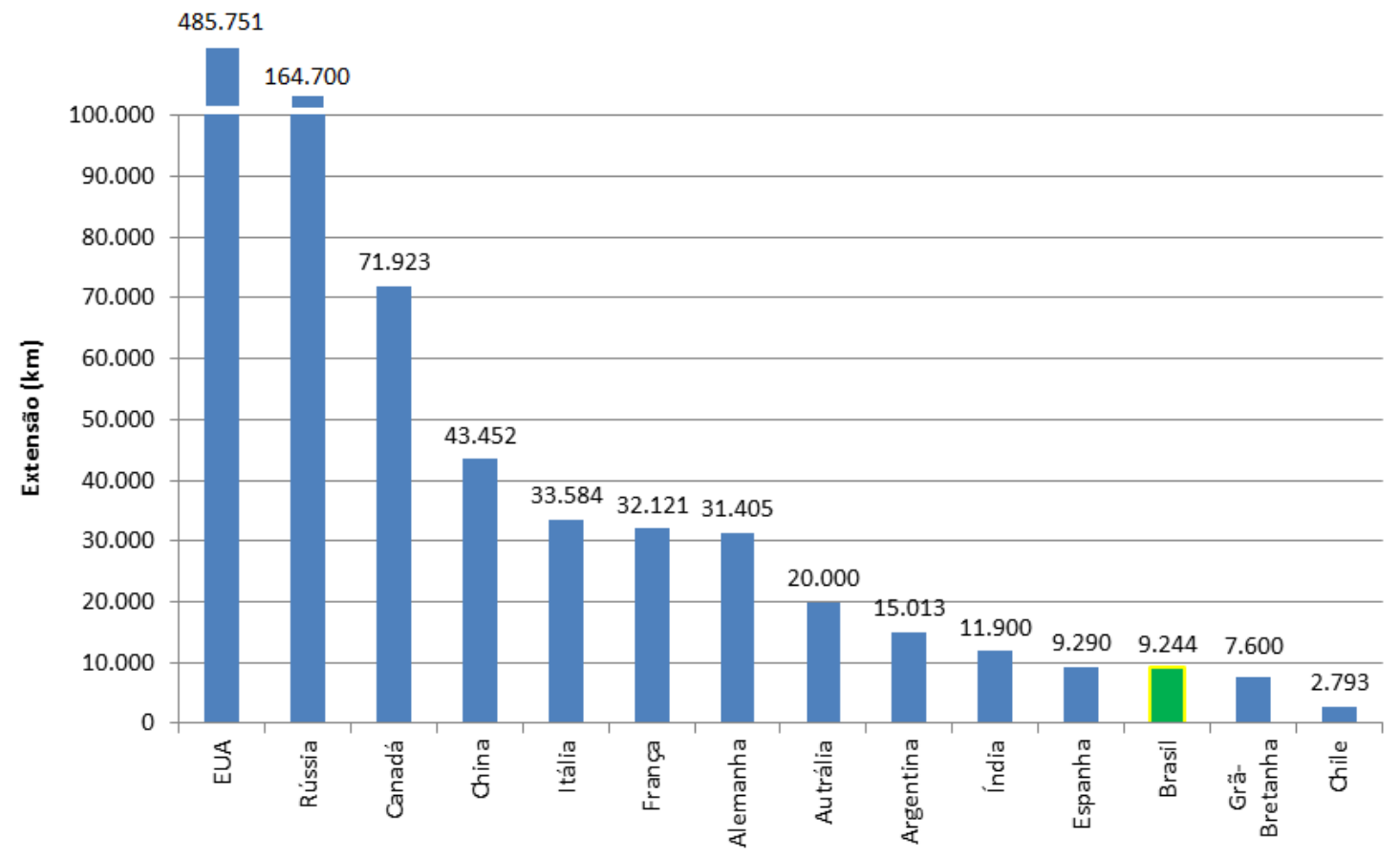

Figura 1.2 - Malhas de Gasodutos de Transporte - Visão Comparativa

Fonte: EPE (2014) 
Os resultados do PEMAT 2022 trouxeram a constatação de que, em um horizonte de decenal (2013 a 2022), não se pretende modificar esse quadro. Uma das limitações apontadas pelo Plano para a expansão da malha encontra-se a demanda de gás natural, que não é suficiente robusta e densa para promover o interesse de agentes privados em investir na ampliação da malha. Em momento algum o planejador propõe medidas alternativas que poderiam disseminar o uso de gás, principalmente em substituição da eletro termia, aumentando a demanda e promovendo o interesse de agentes privados em promoverem a ampliação da rede de gasodutos.

A outra limitação repousa em uma parente ausência de oferta doméstica de gás, que não suportaria expansões maiores de consumo. O pressuposto de oferta doméstica é considerado essencial para justificar um planejamento que indique a necessidade de disseminar o acesso ao gás pelos consumidores. Curiosamente, o planejador parece ter elementos para não considerar projeções de oferta futuras de gás natural, publicadas, por exemplo, pela Petrobras, e que apontam um crescimento significativo da oferta doméstica, além das demandas estimadas, já a partir de 2015. O descolamento entre oferta e demanda aparece em cresimento até 2030, como pode ser observado na Figura 1.3

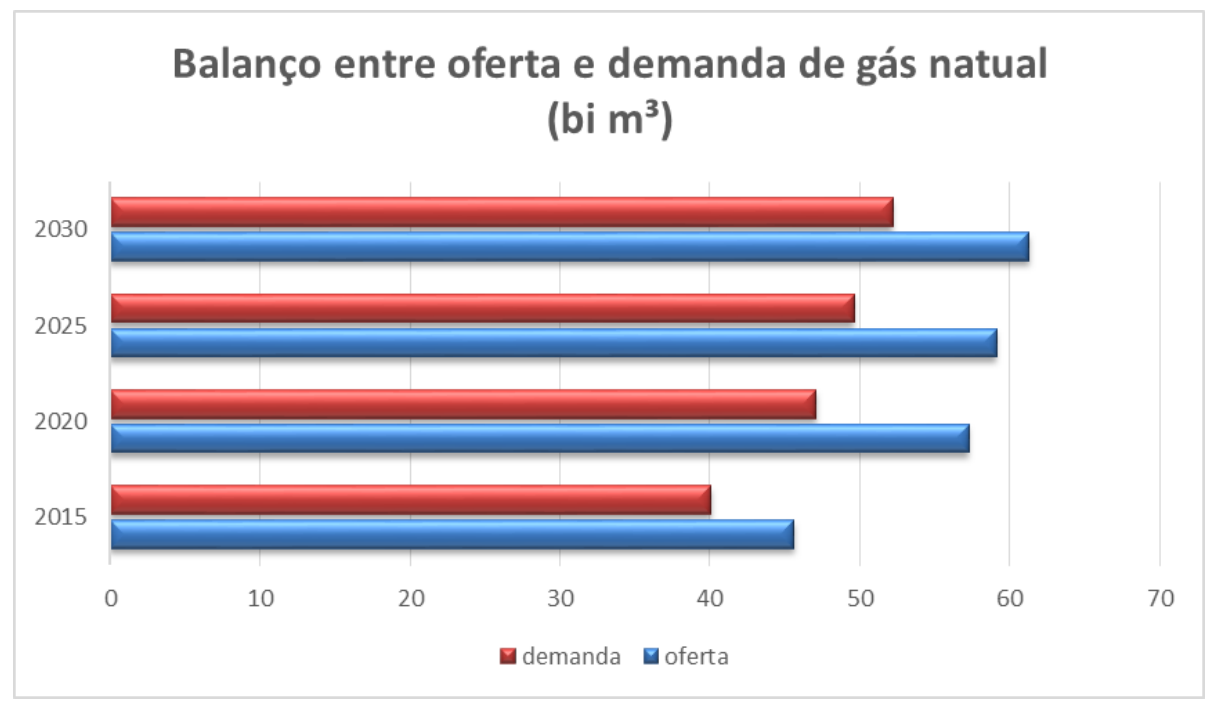

Figura 1.3 - Projeções de Gás Natural - Plano Estratégico da Petrobrás 2030

Fonte: Plano Estratégico Petrobrás 2030, (PB,2013). 
O incremento na oferta de gás natural está relacionado principalmente com as descobertas de Pré-sal, e pelo volume de gás associado que se espera. O desenvolvimento de um mercado cativo de gases combustíveis e a disseminação do uso de gás são meios de agregar valor a este recurso e possibilitar opções de escoamento do gás associado do Pré-sal.

Outros modais de transporte, por exemplo, na forma de sistemas a granel de GNL e GNC, que poderiam ser propostos e utilizados, sem a necessidade de ampliação da malha de transporte dutoviária, são descartados pelo planejador. Sobre essa questão, autora pretende dedicar a sua tese de doutorado no IEE-USP.

Como resultado dessas premissas, considera-se que o PEMAT 2022 representou um verdadeiro "balde de água fria" sobre as pretenções de todos os grupos de interesse que procuram soluções alternativas para fazer deslanchar uma indústria de gás, cujas perspectivas para o futuro sempre parecem auspiciosas, mas se deparam, no curto prazo, a barreiras que parecem instransponíveis.

Através do planejamento setorial, acreditava-se que uma atitude pró-ativa do governo poderia materializar-se, descrevendo possíveis arranjos institucionais, jurídicos e de propriedade, que pudessem viabilizar projetos de infraestrutura de escoamento do gás proveniente das áreas de produção. Explicitar-se-iam alternativas do tipo supplydriven que pudessem impulsionar o mercado do lado da oferta.

Do lado da demanda, aguardavam-se sinalizações sobre políticas que pudessem promover a expansão de uma cultura de uso do gás, gerando cenários críveis e sustentáveis de expansão da demanda, que pudessem incentivar investimentos privados na construção de gasodutos ou qualquer outro modal de transporte de gás, com a certeza do retorno do investimento. Por fim, por meio de um olhar logístico mais abrangente e integrado, esperava-se que o planejador pudesse considerar diversos cenários, contando com modais de escoamento diversos.

Nenhuma das expectativas prévias parecem ter sido atendidas pelo PEMAT 2022. O planejador deixou de ousar e aprisionou-se nas estritas diretrizes propostas pela Lei do Gás. É nessa visão crítica que repousa a maior motivação desta dissertação. Esta reflexão justifica-se e ancora-se na esperança de que o planejamento setorial do gás natural possa ser revisitado, redescobrindo sua importância e, mesmo, relevância, como ferramenta para se observar e se entender as etapas futuras de uma "políticas gasífera nacional", que precisarão amalgamar os diferetes atores do mercado de gás natural. 


\subsection{Metodologia}

A presente dissertação utiliza a metodologia do estudo de caso, através do exame minucioso do PEMAT 2022. Confrontam-se os dados e o conteúdo do PEMAT 2022 com a revisão da literatura proveniente de dados oriundos de fontes oficiais de informações e da legislação (documentos e fontes de domínio público), de artigos, teses e livros de estudiosos do assunto.

Após a revisão da legislação do setor de gás natural, a partir da promulgação da Lei do Petróleo, de 1997, parte-se para verificar o marco atual de planejamento do setor de gás natural, considerando as diretrizes impostas pela Lei do Gás, de 2009. Com isso, encara-se o papel assumido pelos atores governamentais no planejamento.

Seguindo essa visão geral do setor, utiliza-se o estudo de caso para se verificar a concatenação entre o disposto na legislação e o realizado no PEMAT 2022, incluindo os seus resultados, e os confrontando com os princípios que regem o setor de gás natural.

Finalmente, por meio dessa metodologia, pretende-se apontar alternativas para que os resultados de futuras versões do PEMAT estejam mais alinhados com a expectativa dos agentes do setor de gás, e possam, realmente, direcionar o planejamento do mercado de gás natural.

Em particular, assinalam-se as diretrizes que fundamentarão a continuação do plano de pesquisa da autora, que se propõe a encarar opções logísticas e tecnológicas bem mais abrangentes, e que podem ser atrativas para que agentes privados possam efetivamente contribuir com investimentos na expansão da malha de escoamento dos gases, incluindo diversos tipos de modais de transporte e se desprendendo da abordagem restrita do PEMAT 2022, que se concentrou exclusivamente nos gasodutos de alta pressão.

\subsection{Estrutura capitular da dissertação}

A dissertação é composta por três capítulos, além dessa introdução e da conclusão. No primeiro capítulo é traçado o resgate da legislação do setor de gás natural, a partir da Lei do Petróleo de 1997. No segundo capítulo, detalha-se o PEMAT 2022, em seus aspectos metodológicos e nos seus resultados. No terceiro capítulo, são feitas as considerações críticas dos resultados e das metodologias adotadas no PEMAT 2022. As 
críticas aqui apresentadas assentam-se nos princípios jurídicos buscados pelos legisladores e na visão de uma cultura gasífera que agregue a potencialidade energética do gás nos diversos usos finais. 


\section{LEGISLAÇÃO DO SETOR DE GÁS NATURAL E O PLANEJAMENTO SETORIAL}

\subsection{Introdução}

Nesse capítulo apresenta-se a legislação do setor de gás natural a partir da publicação da Lei do Petróleo. Através da legislação setorial é possível visualizar o papel desempenhado por cada ator governamental, assim como pela iniciativa privada, no sentido de viabilizar a construção de um mercado de gás natural competitivo e eficiente.

Dentro dessa lógica, por competição, o trabalho entende que se trata de uma estrutura de "mercado em que grande número de compradores e vendedores independentes competem por mercadorias idênticas e negociam livremente entre si."

E, por eficiência, a dissertação igualmente adota o conceito do Dicionário Michaelis de Português, que compreende "1 Ação, capacidade de produzir um efeito; eficácia, 2 Rendimento", e em que por eficácia se entende "1 Qualidade daquilo que é eficaz. 2 Qualidade daquilo que produz o resultado esperado; eficiência.” (MICHAELIS, 2014).

Assim, além da visualização das competências governamentais, a legislação fornece subsídios para as ações de planejamento do governo, e que nesse sentido, balizam a segurança jurídica almejada pela iniciativa privada no setor de gás natural, com características de capital intensivo e custos afundados.

As especificidades físicas e econômicas do setor de gás natural devem estar insertas na legislação, sob pena de que a incongruência entre lei e mundo fático criem insuficiências, incoerências e ineficiências, maculando toda potencialidade de crescimento de um setor em específico.

É nesse sentido que se reveste a importância da norma, que é regular relações, proporcionar efeitos harmônicos no mercado e, sobretudo, do ponto de vista do investidor, trazer segurança jurídica e transparência para um mercado extremamente exigente.

Com isso, o item 2.2 traz o conteúdo da Lei do Petróleo no setor de gás natural, começando pelos princípios da Política Energética Nacional. Em seguida, apresentam-se o histórico dos projetos de lei que culminaram na atual Lei do Gás, em que se ressalta a perspectiva dos agentes econômicos que provocaram o governo no sentido de criar 
condições jurídicas, regulatórias e contratuais para o desenvolvimento da indústria do gás natural.

No item 2.4, apresenta-se a Lei do Gás, suas perspectivas e suas regras voltadas ao planejamento setorial. O tópico 2.5 adentra ainda mais nessa função de governo, definindo o que é planejamento, qual seu papel e sua função e o que a sociedade pode esperar do governo quando exerce a atividade de planejamento. $\mathrm{O}$ item 2.6 traz breves considerações finais do capítulo.

\subsection{A Lei do Petróleo e o setor de gás natural}

A Lei do Petróleo foi resultado de um amplo debate ocorrido no Congresso Nacional desde das discussões que permitiram a mudança Constitucional decorrente da Emenda n. 09, de 1995, que flexibilizou o monopólio da União no setor de petróleo e gás natural.

Em 1988, quando promulgada a Constituição Federal, o Brasil estava saindo de uma ditatura militar, em que a indústria de petróleo e gás natural era encarada como de interesse estratégico nacional. Por tal motivo, o texto original da Constituição trouxe todo o caráter nacionalista e inseriu a indústria de petróleo e gás natural entre as atividades de monopólio do Estrado brasileiro.

Todavia, a partir da década de 1990, com os movimentos de privatização e de redução do papel de intervenção direta do Estado na economia, por meio de empresas públicas ou de participação em sociedades de economia mista, a Emenda Constitucional n. 09, de 1995, reformulou o texto original e estabeleceu a possibilidade de a União contratar com empresas estatais ou privadas a realização das atividades da indústria de petróleo e gás natural, conforme lei a ser editada. Essa Emenda flexibilizou as atividades do upstream ao downstream, excetuando a atividade de distribuição de gás natural canalizado.

Em relação à distribuição de gás natural canalizado, coube à Emenda Constitucional n. 05, de 1995, flexibilizar o setor de gás canalizado, de competência dos Estados federados, com a previsão do uso da concessão por qualquer sociedade empresária brasileira, privada ou pública, ou por meio da exploração direta. Anteriormente, somente empresas estatais poderiam explorar essa atividade. 
A Figura 2.1 apresenta a resultante estrutura de competências governamentais na indústria de gás natural, ressaltando as etapas onde é possível a criação de estruturas regulatórias concorrenciais; e, os estágios onde existem um monopólio natural decorrente da especificidade da indústria de redes, do qual o transporte e a distribuição se enquadram.

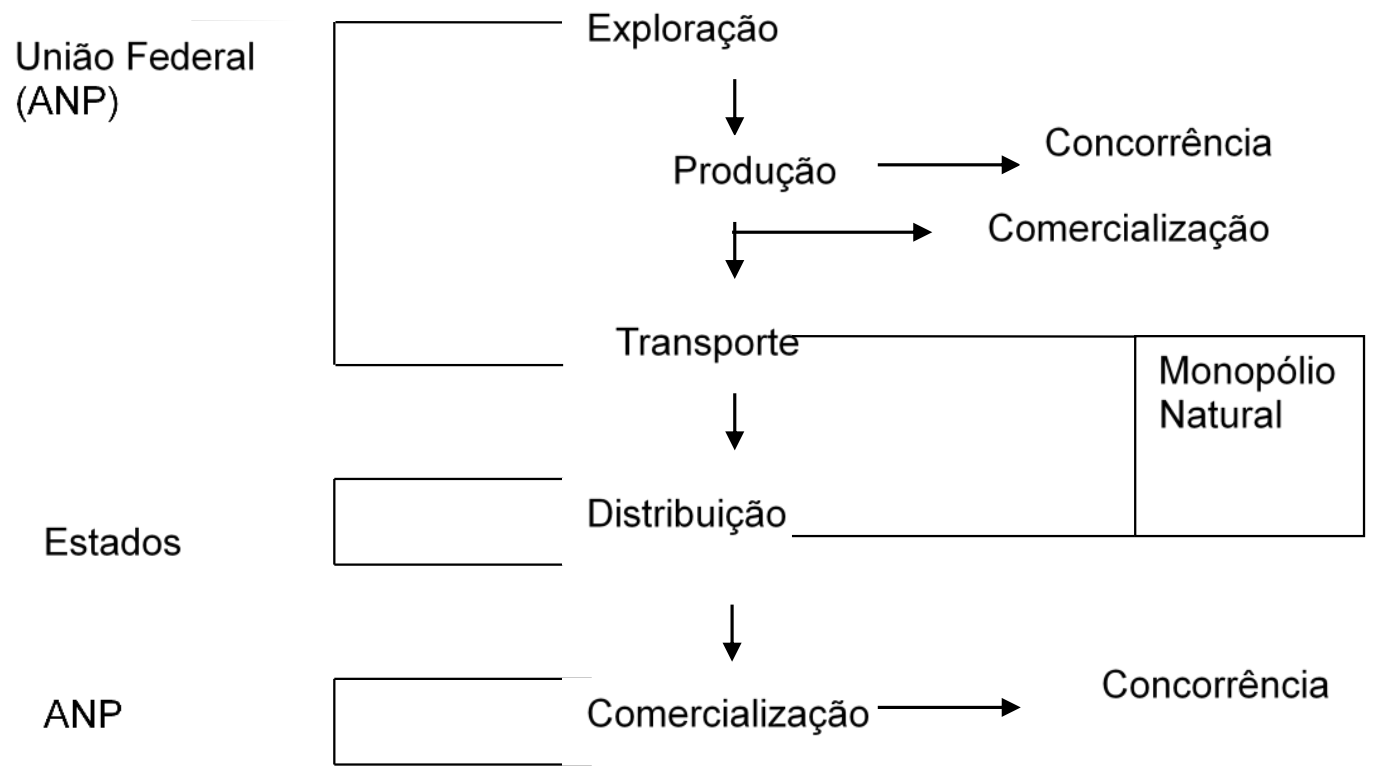

Figura 2.1 - Estrutura do Mercado: A cadeia do gás natural

Fonte: Adaptações feitas por (Costa, 2006), a partir de (PFEIFFER, 2004, p.78).

Conforme explicado e dado tais mudanças no plano Constitucional, o Congresso Nacional tinha a tarefa de promulgar uma Lei Ordinária para delinear o setor de petróleo e gás natural, com exceção da atividade de distribuição local de gás, sob competência estadual.

Em 06 de agosto de 1997, o Congresso cumpriu esse escopo preliminar de continuidade de mudanças legislativas, e promulgou a Lei Federal 9.478, conhecida como Lei do Petróleo, composta de 83 artigos e que iniciou um novo capítulo na história da indústria de petróleo e de gás natural brasileira, conforme tratado nos itens 2.2.1 e seguintes. 


\subsubsection{Dos princípios da Política Energética Nacional (PEN)}

A Lei do Petróleo não é somente uma lei do setor de petróleo e gás natural, ela possui um caráter mais amplo, o que pode ser visto logo no seu primeiro artigo que traz os "Princípios e Objetivos da Política Energética Nacional."

O efeito dessa afirmação decorre da aplicação da Lei do Petróleo para diversos tipos de energia primária e secundária, seja eletricidade, seja os derivados de petróleo e gás natural.

Os objetivos da Política Energética Nacional (PEN) compostos de um elenco inicial de 11 incisos, hoje já compreendem 18 incisos, que foram acrescidos aos longo dos últimos anos com a promulgação da Lei n. 11.097, de 13 de janeiro de 2005, que dispõe, dentre outras matérias, sobre a introdução do biodiesel na matriz energética brasileira; e, a Lei n. 12.490, de 16 de setembro de 2011, que dentre outros assuntos, altera as Leis nos 9.478, de 6 de agosto de 1997, e 9.847, de 26 de outubro de 1999, que dispõem sobre a política e a fiscalização das atividades relativas ao abastecimento nacional de combustíveis(BRASIL, 2014d) (BRASIL, 2014e).

No que toca à indústria de gás natural, pode-se separar os objetivos da PEN em de efeitos "direitos" e "indiretos", considerando a redação do texto em si, bem como o direcionamento de políticas com teor mais específico. Dessa forma, os objetivos de efeito “direitos" referentes à indústria do gás natural em si, concentram-se, basicamente, no inciso VI do artigo $1^{\mathrm{o}}$ que pugnam pelo incremento, em bases econômicas, da utilização do gás natural.

Os objetivos de efeitos "indiretos" possuem o caráter bem mais geral e podem ser identificados com outras fontes de energia primária, como os incisos I (preservar o interesse nacional), II (promover o desenvolvimento, ampliar o mercado de trabalho e valorizar os recursos energéticos), III (proteger os interesses do consumidor quanto a preço, qualidade e oferta dos produtos), IV (proteger o meio ambiente e promover a conservação de energia), VII (identificar as soluções mais adequadas para o suprimento de energia elétrica nas diversas regiões do País), IX (promover a livre concorrência), X (atrair investimentos na produção de energia), XI (ampliar a competitividade do País no mercado internacional) e XVIII (mitigar as emissões de gases causadores de efeito estufa e de poluentes nos setores de energia e de transportes, inclusive com o uso de biocombustíveis) (BRASIL, 2014c). 
Dessa maneira, enxerga-se que o PEN contempla, desde a promulgação da Lei do Petróleo, a importância de direcionar políticas públicas através de técnicas de planejamento para o incremento do uso do gás dentre os energéticos disponíveis na matriz de oferta brasileira, seja com a menção no texto de forma "direta", seja de maneira "indireta."

Tal postura traz um dever do Estado, quando agindo em seu papel de planejador, de atuar no mercado, incentivando e criando condições para o investimento no setor de gás natural.

Do que se extrair a importância da Lei do Petróleo no planejamento energético do setor de gás natural por meio dos objetivos da PEN, e também dos órgãos setoriais, igualmente, criados e/ou regulados nessa Lei, conforme tratado no item a seguir.

\subsubsection{Os órgãos setoriais na Lei do Petróleo}

O setor de gás natural é composto por diversos tipos de órgãos governamentais. Destaca-se o Ministério de Minas e Energia (MME), órgão direto da Administração Pública; o Conselho Nacional de Política Energética (CNPE), órgão de assessoramento da Presidência; a Agência Nacional do Petróleo, Gás Natural e Biocombustíveis (ANP), autarquia sob regime especial prevista na Constituição Federal; e, a Empresa de Pesquisa Energética (EPE), empresa pública federal.

Esses atores foram criados por diversas leis, que serão abordadas ao longo dessa dissertação. Nesse momento, focaliza-se, sobretudo, nos dois entes criados pela Lei do Petróleo, quais sejam, CNPE e ANP. Basicamente, essa lei trouxe os parâmetros de institucionalização desses agentes com a previsão de posterior decreto regulamentador. Nos tópicos seguintes, abordam-se as funções de cada um desses entes descritos nessa Lei. 


\subsubsection{CNPE}

$\mathrm{O}$ artigo $2^{\circ}$ da Lei do Petróleo criou o CNPE, vinculado à Presidência da .República e presidido pelo MME. As atribuições do CNPE estão elencadas ao longo de onze incisos $^{4}$ (BRASIL, 2014c).

Enquanto órgão de assessoramento do Presidente da República, o CNPE terá a função primordial de opinar em assuntos relacionados a políticas nacionais e medidas específicas destinadas a:

(i) promover o aproveitamento racional dos recursos energéticos do País;

(ii) assegurar, em função das características regionais, o suprimento de insumos energéticos às áreas mais remotas ou de difícil acesso do País;

(iii) rever periodicamente as matrizes energéticas aplicadas às diversas regiões do País, considerando as fontes convencionais e alternativas e as tecnologias disponíveis;

(iv) estabelecer diretrizes para programas específicos, como os de uso do gás natural, do carvão, da energia termonuclear, dos biocombustíveis, da energia solar, da energia eólica e da energia proveniente de outras fontes alternativas;

(v) estabelecer diretrizes para a importação e exportação, de maneira a atender às necessidades de consumo interno de petróleo e seus derivados, biocombustíveis, gás natural e condensado, e assegurar o adequado funcionamento do Sistema Nacional de Estoques de Combustíveis e o cumprimento do Plano Anual de Estoques Estratégicos de Combustíveis;

(vi) sugerir a adoção de medidas necessárias para garantir o atendimento à demanda nacional de energia elétrica, considerando o planejamento de longo, médio e curto prazos, podendo indicar empreendimentos que devam ter prioridade de licitação e implantação;

(vii) estabelecer diretrizes para o uso de gás natural como matéria-prima em processos produtivos industriais, mediante a regulamentação de condições e

\footnotetext{
${ }^{4}$ Além desses incisos, $\mathrm{o}$ art. $2^{\circ}$ conta com os seguintes parágrafos: "§ $1^{\circ}$ Para o exercício de suas atribuições, o CNPE contará com o apoio técnico dos órgãos reguladores do setor energético. $\S 2^{\circ} \mathrm{O}$ CNPE será regulamentado por decreto do Presidente da República, que determinará sua composição e a forma de seu funcionamento."
} 
critérios específicos, que visem a sua utilização eficiente e compatível com os mercados interno e externos;

(viii) definir os blocos a serem objeto de concessão ou partilha de produção;

(ix) definir a estratégia e a política de desenvolvimento econômico e tecnológico da indústria de petróleo, de gás natural, de outros hidrocarbonetos fluidos e de biocombustíveis, bem como da sua cadeia de suprimento;

(x) induzir o incremento dos índices mínimos de conteúdo local de bens e serviços, a serem observados em licitações e contratos de concessão e de partilha de produção;

(xi) definir diretrizes para comercialização e uso de biodiesel e estabelecer, em caráter autorizativo, quantidade superior ao percentual de adição obrigatória fixado em lei específica (BRASIL, 2014c).

Como se percebe, a partir da leitura de suas funções, o CNPE terá papel fundamental no tocante ao planejamento do setor de gás natural. Além de competências específicas, como a de definição de diretrizes de programas específicos de uso do gás natural, incluindo-o como matéria-prima, o CNPE opinará na estratégia e na política de desenvolvimento econômico e tecnológico da indústria de gás natural.

Dentro dessa perspectiva, considerando o planejamento do setor em análise, o CNPE enquanto órgão de assessoramento poderá ser o diferencial para a indústria do gás natural quando deefende uma visão mais ampla de usos, incluindo a adoção de diversos modais de escoamento com vistas a, por exemplo, criação de clusters de consumidores de gás que alavanquem posteriores malhas de gasodutos.

É bem significativo o poder potencial do CNPE, quando da adoção de uma cultura de uso e de massificação do uso do gás, que com certeza, pela leitura da Lei, ao se pugnar por tal papel, pode significar a expansão ou a retração dos investimentos públicos e privados.

\subsubsection{ANP}

A Lei do Petróleo também instituiu a ANP, submetida ao regime autárquico especial, como órgão regulador da indústria do petróleo, gás natural, seus derivados e biocombustíveis, vinculada ao MME (BRASIL, 2014c). 
A ANP tem o objetivo de promover a regulação, a contratação e a fiscalização das atividades econômicas integrantes da indústria do petróleo, do gás natural e dos biocombustíveis (BRASIL, 2014c). Dentre suas diversas funções delineadas na Lei do Petróleo, atualmente, no tocante ao setor de gás, existem as competências incluídas pela Lei do Gás (Lei n. 11.909, de 2009).

Na redação original da Lei do Petróleo, as competências da ANP voltadas ao setor do gás natural estavam particularmente vinculadas ao setor de petróleo. Dessa forma, genericamente, à ANP caberia implementar, em sua esfera de atribuições, a política nacional de petróleo, gás natural e biocombustíveis.

Com a edição da Lei do Gás, a Lei do Petróleo passou a conter atribuições da ANP bem específicas com o sentido de fazer valer as novas regras do setor do gás, o que inclui novos instrumentos jurídicos como o da concessão do transporte, a chamada pública para a alocação de capacidade, regras sobre livre acesso, dentre outros.

Assim, a ANP deve:

(i) autorizar a prática das atividades de refinação, liquefação, regaseificação, carregamento, processamento, tratamento, transporte, estocagem e acondicionamento;

(ii) regular e fiscalizar o acesso à capacidade dos gasodutos;

(iii) promover, direta ou indiretamente, as chamadas públicas para a contratação de capacidade de transporte de gás natural, conforme as diretrizes do MME;

(iv) registrar os contratos de transporte e de interconexão entre instalações de transporte, inclusive as procedentes do exterior, e os contratos de comercialização, celebrados entre os agentes de mercado;

(v) informar a origem ou a caracterização das reservas do gás natural contratado e a ser contratado entre os agentes de mercado;

(vi) regular e fiscalizar o exercício da atividade de estocagem de gás natural, inclusive no que se refere ao direito de acesso de terceiros às instalações concedidas;

(vii) elaborar os editais e promover as licitações destinadas à contratação de concessionários para a exploração das atividades de transporte e de estocagem de gás natural; 
(viii) celebrar, mediante delegação do MME, os contratos de concessão para a exploração das atividades de transporte e estocagem de gás natural sujeitas ao regime de concessão;

(ix) autorizar a prática da atividade de comercialização de gás natural, dentro da esfera de competência da União;

(x) estabelecer critérios para a aferição da capacidade dos gasodutos de transporte e de transferência;

(xi) articular-se com órgãos reguladores estaduais e ambientais, objetivando compatibilizar e uniformizar as normas aplicáveis à indústria e aos mercados de gás natural (BRASIL, 2014c).

Pelo que se infere dos pontos específicos incluídos pela Lei do Gás na Lei do Petróleo, no que toca ao planejamento setorial, a ANP terá um papel de executor das diretrizes do MME, por exemplo, quando celebra contratos de concessão de transporte, ou quando promove chamadas públicas para a alocação de capacidade em gasodutos de transporte.

A ANP também tem os deveres de (i) informar a origem ou a caracterização das reservas que suportarão o fornecimento dos volumes de gás natural contratados; e (ii) para isso, poderá requerer tais dados do agente vendedor do gás natural (BRASIL, 2014c).

Considerando tal aspecto, percebe-se que o CNPE bem mais do que a ANP irá exercer papel significativo no planejamento setorial. Além disso, ressaltam-se as funções do MME, que com a Lei do Gás ficarão bem mais claras e expandidas, que serão abordados no item 2.4.2.

\subsubsection{Do Upstream ao Downstream: o gás natural na Lei do Petróleo}

Costa e Santos (2006, p. 04) já ressaltaram que o tratamento dado pela Lei do Petróleo ao setor de gás natural foi bastante precário, o que motivou a posterior edição da Lei do Gás, em 2009. Para esses autores, é relevante entender que o setor de gás natural apresenta características referentes à indústria mineraria, na medida em que a exploração e produção oferecem riscos próprios a essas atividades, conduzem ao esgotamento da jazida, bem como proporcionam rendas econômicas superiores ao nível de lucro normal da atividade industrial. 
Contudo, após a extração do poço, o gás natural apresenta peculiaridades, existentes em indústrias de rede, haja visto o fato de que ele necessariamente precisa de estruturas físicas que detenha a volatilidade própria dos gases. Para melhor entendimento desses conceitos, a Figura 2.2 apresenta-se os tipos de malha de gasodutos e as respectivas áreas de concessão.

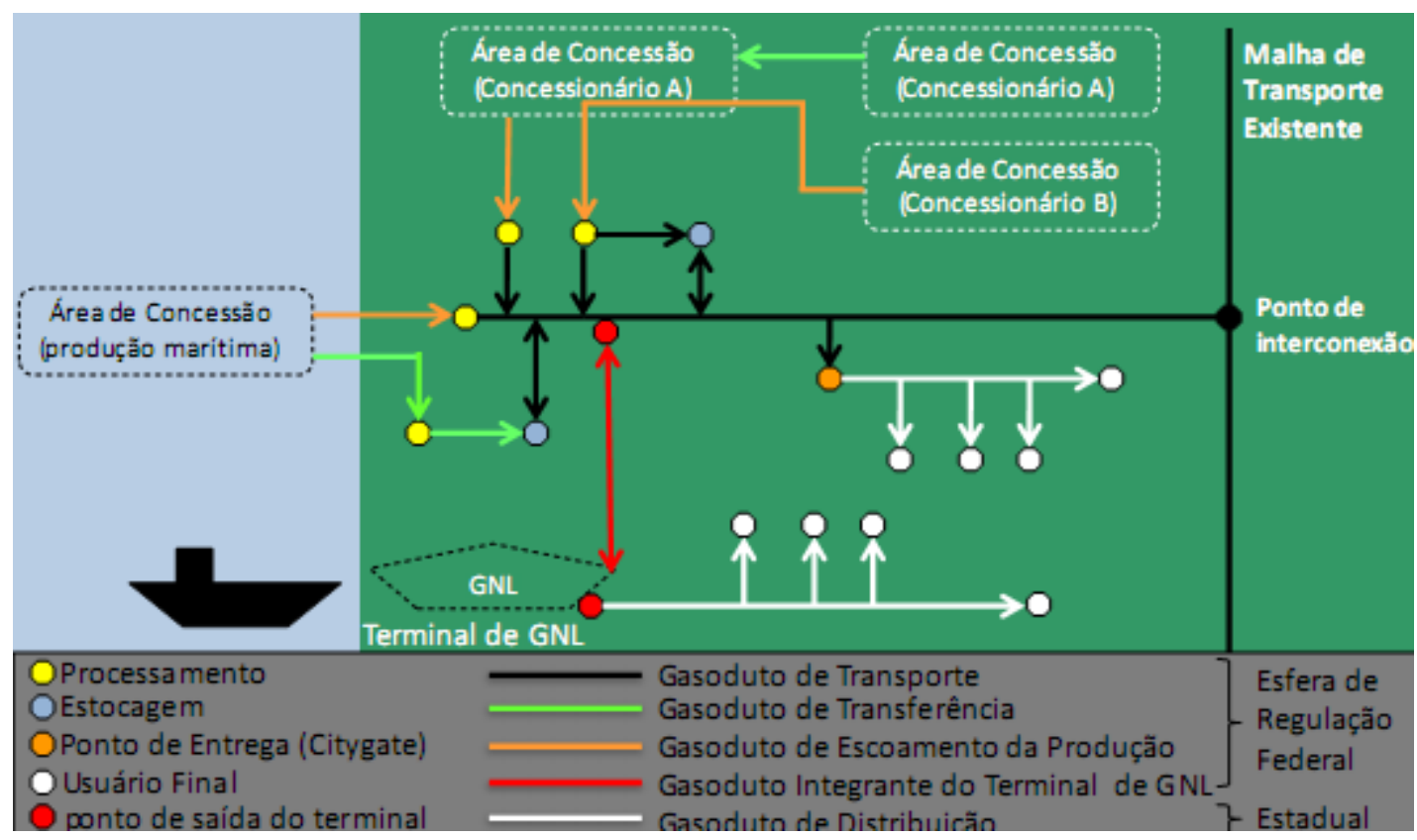

Figura 2.2 - Classificação da malha de gasodutos

Fonte: FIDELIS (2011).

Conforme notam Costa e Santos (2006, p. 03), fora os inúmeros dispositivos que agregam a exploração, o desenvolvimento e a produção do petróleo e do gás natural, como por exemplo, as definições técnicas comuns (Capítulo III - Seção II, art. $6^{05}$ ); os artigos sobre a exploração, o desenvolvimento e a produção, bem como o edital de licitação prévio à assinatura do contrato de concessão e de partilha de produção e as respectivas

\footnotetext{
${ }^{5}$ Veja também o Art. $6^{\circ}$ da Lei do Petróleo: "Para os fins desta Lei e de sua regulamentação, ficam estabelecidas as seguintes definições: I - Petróleo: todo e qualquer hidrocarboneto líquido em seu estado natural, a exemplo do óleo cru e condensado; II - Gás Natural ou Gás: todo hidrocarboneto que permaneça em estado gasoso nas condições atmosféricas normais, extraído diretamente a partir de reservatórios petrolíferos ou gaseíferos, incluindo gases úmidos, secos, residuais e gases raros".
} 
participações governamentais, constantes no Capítulo V (arts. 21 e seguintes); os demais artigos dão pouca atenção ao gás natural.

Para fins de ilustração, o próprio conceito de transporte ${ }^{6}$ é bem genérico ao apontar que se trata de "movimentação de petróleo, seus derivados, biocombustíveis ou gás natural em meio ou percurso considerado de interesse geral." O dispositivo foi alterado pela Lei no 12.490, de 2011, para incluir menção aos biocombustíveis (BRASIL, 2014e). Todavia, não faz menção aos diversos tipos de modais que podem movimentar o gás natural.

No Capítulo VII, encontra-se o regime jurídico que irá revestir a atividade de transporte de Petróleo, seus Derivados e Gás Natural. O art. 56 adota o regime de autorização para construir instalações e efetuar qualquer modalidade de transporte de petróleo, seus derivados e gás natural, seja para suprimento interno ou para importação e exportação. Sendo que esse artigo prescreve o regime de transição com a ratificação de titularidade e direitos, no prazo de cento e oitenta dias, a partir da publicação desta Lei, de empresas proprietárias de equipamentos e instalações de transporte marítimo e dutoviário (BRASIL, 2014c).

$\mathrm{O}$ artigo 58 traz o livre acesso às instalações de movimentação mediante contraprestação, excetuando-se terminais de Gás Natural Liquefeito (GNL). Com redação alterada pela Lei do Gás, o parágrafo primeiro do art. 58 definiu que a ANP fixará o valor e a forma de pagamento da remuneração adequada com base em critérios previamente estabelecidos, caso não haja acordo entre as partes, cabendo-lhe também verificar se o valor acordado é compatível com o mercado (BRASIL, 2014c). Previsto no parágrafo segundo do referido artigo, a ANP regulará a preferência a ser atribuída ao proprietário das instalações para movimentação de seus próprios produtos, com o objetivo de promover a máxima utilização da capacidade de transporte pelos meios disponíveis (Costa e Santos, 2006).

Observa-se que para o segmento de transporte da cadeia de gás natural deveriam ter sido definidas normas específicas, aproveitando-se as normas comuns concernentes à

\footnotetext{
${ }^{6}$ Outro conceito tratado pela Lei do Petróleo é o de transferências. Veja: "VIII - Transferência: movimentação de petróleo, seus derivados, biocombustíveis ou gás natural em meio ou percurso considerado de interesse específico e exclusivo do proprietário ou explorador das facilidades; (Redação dada pela Lei no 12.490, de 2011)." Importante ressaltar que é possível a reclassificação desse tipo de duto. Nesse sentido, o Art. 59. diz "Os dutos de transferência serão reclassificados pela ANP como dutos de transporte, caso haja comprovado interesse de terceiros em sua utilização, observadas as disposições aplicáveis deste Capítulo".
} 
exploração, ao desenvolvimento e à produção do setor de petróleo, com o escopo de promover efetivamente a realização de investimento, a eficiência, a concorrência (aonde possível) e evitar a integração vertical e horizontal. A Lei nº 9.478/97 também não tratou de reger as atividades de gás natural liquefeito e de gás natural comprimido ${ }^{7}\left(\operatorname{Costa~}^{\mathrm{e}}\right.$ Santos, 2006).

A falta de uma legislação consolidada especificamente para a indústria de gás natural gerou incertezas para os agentes que atuam nesta indústria (Costa e Santos, 2006). Com isso, Projetos de Lei foram encaminhados para o Congresso Nacional com o objetivo de sanar esse cenário com a edição de uma lei que enxergasse as necessidades do setor de gás natural e suas especificidades. O que poderia proporcionar segurança aos investidores e o crescimento do mercado. No item 2.3 aborda-se, basicamente, os projetos que culminaram na Lei do Gás.

\subsection{Mudança de paradigmas: projetos de Lei do Gás}

Diante da constatação da necessidade de regras específicas para o setor de gás natural, em 2006, foram encaminhados para discussão no Congresso Nacional, três Projetos de Lei sobre a indústria do gás natural. Nesse item, apresenta-se um breve resumo de cada um desses projetos, ressaltando os pontos relacionados ao planejamento setorial e já projetando os resultados finais das discussões no texto da Lei do Gás, de 2009 .

\subsubsection{Projeto de Lei ${ }^{0}$ 226/2005 e o seu substitutivo}

O Projeto de Lei $\mathrm{n}^{\circ}$ 226/2005, de autoria do senador Rodolpho Tourinho dispôs sobre "importação, exportação, processamento, transporte, armazenagem, liquefação, regaseificação, distribuição e comercialização de gás natural.”

No texto de justificativa desse Projeto de Lei, o senador Rodolpho Tourinho alegou a relevância do estabelecimento de um regime legal mais adequado para a indústria

\footnotetext{
${ }^{7} \mathrm{O}$ que foi feito posteriormente pelas respectivas portarias: Portaria ANP n ${ }^{\circ} 118$ de 11.7.2000 que regulamenta as atividades de distribuição de gás natural liquefeito (GNL) a granel e de construção, ampliação e operação das centrais de distribuição de GNL; e a Portaria ANP n ${ }^{\circ} 243$ de 18.10.2000 que regulamenta as atividades de distribuição e comercialização de gás natural comprimido (GNC) a granel e a construção, ampliação e operação de Unidades de Compressão e Distribuição de GNC.
} 
do gás natural, em virtude das lacunas apresentadas na Lei nº 9.478/97 (Costa e Santos, 2006).

Interessante observar que o senador Rodolpho Tourinho também reforça que esse Projeto de Lei serve ao desenvolvimento do mercado de gás natural, em razão da ausência de um marco legal adequado ter inibido investimentos na indústria e agravado a concentração de mercado nas mãos da Petrobrás (Costa e Santos, 2006).

Dessa forma, o novo modelo legal da indústria do gás natural deveria, portanto, promover o investimento; aperfeiçoar a regulação de determinadas atividades, prevenindo o exercício do poder de monopólio, impedindo práticas anti competitivas e garantindo a utilização da infraestrutura existente, mediante tarifas justas e adequadas (Costa e Santos, 2006).

Esse Projeto apresentava uma grande inovação para o setor de transporte. Em seu art. $6^{\circ}$ institui o Operador do Sistema Nacional de Transporte de Gás Natural (ONGÁS), pessoa jurídica de direito privado, sem fins lucrativos, com objetivo de promover o uso eficiente dos Gasodutos de Transporte e Unidades de Armazenagem de Gás Natural (Costa e Santos, 2006).

Neste sentido, por exemplo, ficaria sob a responsabilidade do ONGÁS, a interação com a Empresa de Pesquisa Energética (EPE) na formulação de planos de expansão do sistema, assim como no PL encontravam-se atribuições do ONGÁS relacionadas com a necessária interface entre esse órgão e o Operador Nacional do Sistema Elétrico (ONS) (Costa e Santos, 2006).

Com relação a ANP, o art. 10 determinava as suas atribuições. Dentre elas, destacam-se: elaborar editais e promover licitações para a concessão das atividades de transporte e de armazenagem de gás natural; fixar as tarifas de transporte e de armazenagem de gás natural; autorizar a construção e operação de gasodutos de transferência e de produção, bem como reclassificar os gasodutos de transferência; interagir com a EPE na formulação de planos de expansão do sistema de transporte e por fim, fiscalizar as atividades do ONGÁS (Costa e Santos, 2006).

Contudo, no Substitutivo do PL em análise, as competências que eram destinadas a ANP foram transferidas para o Poder Executivo (Costa e Santos, 2006).

Em seu art. 11, o PL determinava que a atividade de transporte de gás natural por meio de dutos seria exercida mediante contratos de concessão, precedidos de licitação. A concessão somente poderia ser obtida para o exercício da atividade de transporte de gás natural por meio de dutos às empresas que se dedicassem, com exclusividade, a esta 
atividade e que atendessem aos requisitos técnicos, econômicos e jurídicos estabelecidos pela ANP (Costa e Santos, 2006).

No caso de interesse em expansão dos gasodutos de transporte, as empresas deveriam submeter projeto técnico-econômico a ANP, nas hipóteses previstas no contrato de concessão ou em circunstâncias que assim se justificassem (Costa e Santos, 2006).

O PLS 226/2005, após tramitação no Senado Federal, foi para a Câmara de Deputados, transformando-se no PL 334/2007, que foi posteriormente arquivado (CÂMARA, 2015b).

\subsubsection{Projeto de Lei $\mathrm{n}^{\circ}$ 6673, de 2006 - MME}

Além do PL do senador Rodolpho Tourinho, o MME encaminhou PL ao Congresso Nacional "sobre a movimentação, estocagem e comercialização de gás natural, e dá outras providências" (Costa e Santos, 2006).

Nas Justificativas do PL 6673, o MME reconheceu que as condições similares dadas ao petróleo e ao gás natural pela Lei nº 9.478/97 não mostrou a eficiência desejada (Costa e Santos, 2006).

Dentre os principais pontos desse PL, Costa e Santos (2006) citam a introdução do regime de concessão (precedida de licitação) para a construção e operação de gasodutos, com a possibilidade da outorga de autorizações para dutos de menor importância (art. $\left.1^{\circ}\right)$.

No que atine a ANP, assentou-se uma maior competência para a execução de suas

atribuições incluindo, em seu âmbito, a criação de um organismo destinado a supervisionar a operação da rede de gasodutos (Costa e Santos, 2006).

O referido PL, após a tramitação de três anos, que ensejou abrangente discussão no Congresso Nacional, transformou-se na Lei do Gás, que será comentada amplamente no item 2.4 (CAMARA, 2014).

\subsubsection{PL 6666/06}

O Projeto de Lei 6666/2006 de autoria do deputado federal Luciano Zica (PT/SP) caracterizava-se por propor a alteração da Lei nº 9.478/9. 
O PL 6673/06 foi apensado ao PL 6666/06 com o intuito de serem examinados conjuntamente, visto a oportunidade e conveniência de tramitarem juntos no processo legislativo (Costa e Santos, 2006).

Essa terceira via de PL do Gás Natural, em síntese, detalha as características da indústria do gás natural que não foi devidamente tratado pela Lei do Petróleo e aproveita os pontos semelhantes da indústria do petróleo no que concerne à exploração e produção.

Esse PL continuava apoiando a autorização como instrumento jurídico para que empresas interessadas realizassem qualquer modalidade de transporte e estocagem de petróleo, seus derivados e gás natural (Costa e Santos, 2006).

Ao final, o PL 6666 foi apensado ao PL 337/2007, originário do PLS 226/2005, de autoria do senador Rodolpho Tourinho e comentado no item 2.3.1. Esses Projetos foram arquivados (CÂMARA, 2015a).

\subsection{A Lei do Gás}

Após a tramitação do Projeto de Lei 6673/2006, examinado no item 2.3.2, o texto final da Lei do Gás foi promulgado em 04 de março de 2009. No texto final não constou o ONGÁS.

No capítulo das definições, a Lei já traz dentre diversos conceitos, os de $\mathrm{GNL}^{8}$, de GNC $^{9}$, de Gasoduto de Transferência ${ }^{10}$, de Gasoduto de Transporte. ${ }^{11}$

No que toca ao conceito de transporte de gás natural, a Lei do Gás já aponta uma de suas primeiras incoerências, porquanto o vincula ao único modal "gasodutos":

\footnotetext{
${ }^{8}$ XV - Gás Natural Liquefeito - GNL: gás natural submetido a processo de liquefação para estocagem e transporte, passível de regaseificação em unidades próprias.

${ }^{9}$ XVI - Gás Natural Comprimido - GNC: todo gás natural processado e acondicionado para o transporte em ampolas ou cilindros à temperatura ambiente e a uma pressão que o mantenha em estado gasoso;

${ }^{10}$ XVII - Gasoduto de Transferência: duto destinado à movimentação de gás natural, considerado de interesse específico e exclusivo de seu proprietário, iniciando e terminando em suas próprias instalações de produção, coleta, transferência, estocagem e processamento de gás natural.

${ }^{11}$ XVIII - Gasoduto de Transporte: gasoduto que realize movimentação de gás natural desde instalações de processamento, estocagem ou outros gasodutos de transporte até instalações de estocagem, outros gasodutos de transporte e pontos de entrega a concessionários estaduais de distribuição de gás natural, ressalvados os casos previstos nos incisos XVII e XIX do caput deste artigo, incluindo estações de compressão, de medição, de redução de pressão e de entrega, respeitando-se o disposto no $§ 20$ do art. 25 da Constituição Federal.
} 
“movimentação de gás natural em gasodutos de transporte, abrangendo a construção, a expansão e a operação das instalações" (BRASIL, 2014a).

Não obstante, a referência tão somente à estrutura fixa, é reconhecida pela própria Lei a presença de outros modais, como já apontado, porque a Lei define GNL e GNC, assim como na conceituação de terminal de GNL ${ }^{12}$ consta a menção de "entrega do gás natural à malha dutoviária ou a outros modais de transporte" (BRASIL, 2014a).

A Figura 2.3 mostra a cadeia de valor do gás natural, tanto por gasodutos, quanto por terminais que oferecem a possibilidade do transporte por návios metaneiros, dentro da perspectiva do uso do modal de GNL.

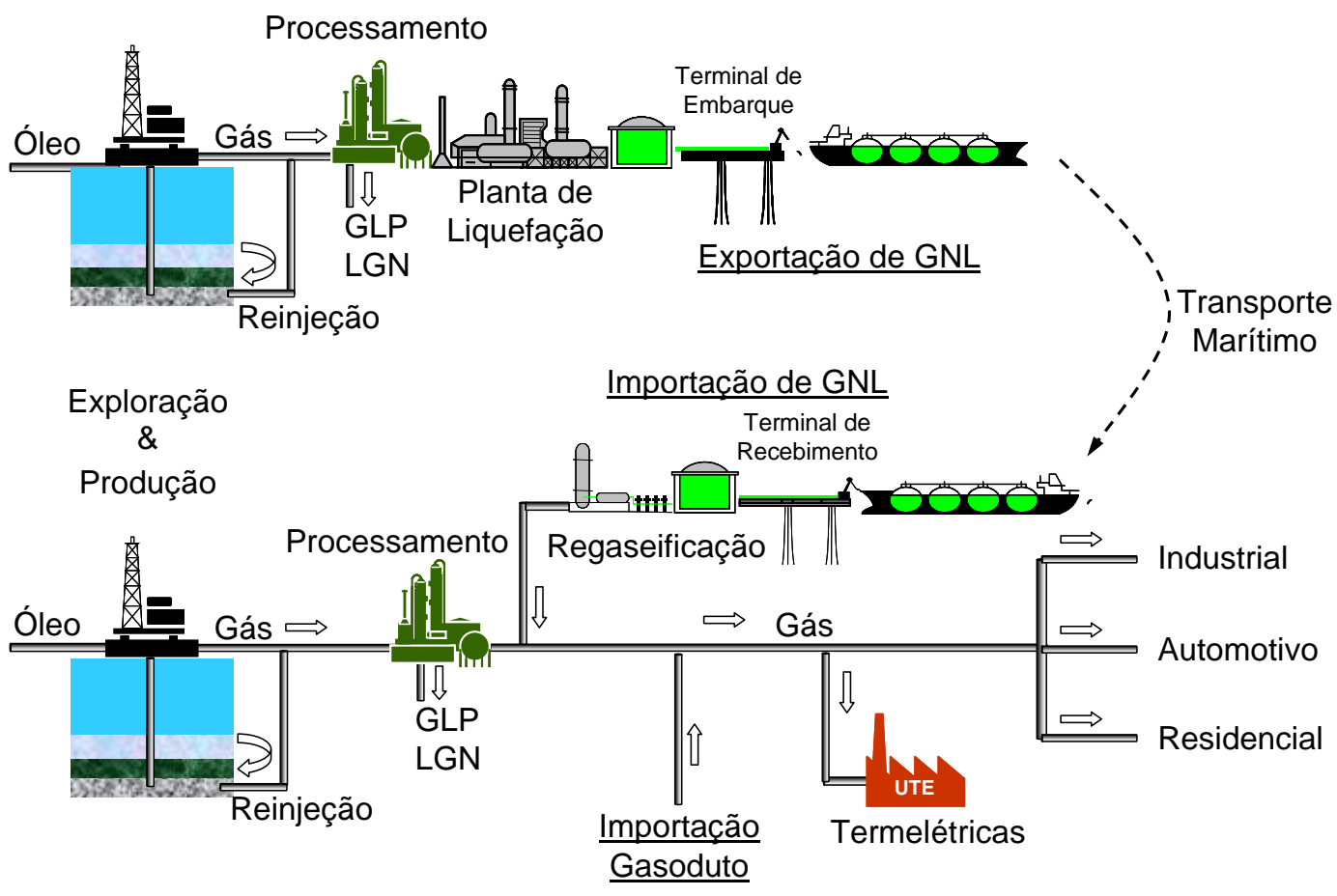

Figura 2.3 - Cadeia de valor do gás natural e do GNL

Fonte: Demori (2008).

Apesar da existência da previsão de outros modais, passados cinco anos iniciais da sua entrada em vigor, a Lei do Gás ficou conhecida pelos agentes como a lei do transporte por gasodutos de gás. De fato, a Lei do Gás na maior parte dos seus dispositivos

\footnotetext{
${ }^{12}$ XXVII - Terminal de GNL: instalação utilizada para a liquefação de gás natural ou para a importação, descarga e regaseificação de GNL, incluindo os serviços auxiliares e tanques de estocagem temporária necessários para o processo de regaseificação e subsequente entrega do gás natural à malha dutoviária ou a outros modais de transporte.
} 
trata direta ou indiretamente desse segmento em específico, a começar pelo regime de concessão, edital de licitação, procedimento de chamada pública de alocação de capacidade, planejamento setorial pautado na malha fixa, dentre outros pontos. Nos itens 2.4.1 e seguintes serão tratados cada um desses pontos dentro da perspectiva do planejamento setorial.

\subsubsection{Regime jurídico}

\subsubsection{Da concessão}

$\mathrm{O}$ art. $3^{\circ}$ da Lei do Gás adota o regime de concessão, precedida de licitação como o regime jurídico preferencial da atividade de transporte de gás natural. Sendo assim, sociedade e consórcio regidos pelas leis brasileiras deverão participar da licitação e ao final sendo vencedor assinar o contrato de concessão com o Poder Concedente (BRASIL, 2014a).

A concessão aplica-se a todos os gasodutos de transporte considerados de interesse geral. Para viabilizar os investimentos iniciais e a disposição de investidores, o parágrafo segundo do art. $3^{\circ}$ prescreveu o período de exclusividade para os carregadores iniciais. A competência de fixação do período de exclusividade é do MME, com assessoria da ANP. O critério para a seleção do vencedor será o de menor receita anual, que corresponde ao montante anual a ser recebido pelo transportador para a prestação do serviço contratado (BRASIL, 2014a).

O parágrafo segundo do art. 10 trata das tarifas e assim dispõe:

As tarifas de transporte de gás natural a serem pagas pelos carregadores para o caso dos gasodutos objeto de concessão serão estabelecidas pela ANP, aplicando à tarifa máxima fixada no processo de chamada pública o mesmo fator correspondente à razão entre a receita anual estabelecida no processo licitatório e a receita anual máxima definida no edital de licitação. (BRASIL, 2014a)

Como se percebe do texto legal, para a preparação do edital de licitação e do respectivo contrato de concessão, o MME contará com dados e informações necessários para formatar as regras de entrada das empresas interessadas no setor de transporte, o que já demonstra a organização setorial voltada ao planejamento. 


\subsection{Do Edital e da minuta do contrato de concessão}

O Edital e o contrato de concessão serão elaborados pela ANP, inclusive, esse ente celebrará os contratos de concessão, mediante delegação do MME. Para a licitação, além do edital, os agentes já terão acesso à minuta da concessão. Os resultados do planejamento setorial desejados pelo MME já estarão nesse instrumento (BRASIL, 2014a). Dentro dessa perspectiva, o art. 17 prevê os critérios básicos que devem estar no edital:

(i) o percurso do gasoduto de transporte objeto da concessão, a capacidade de transporte projetada e os critérios de dimensionamento;

(ii) a receita anual máxima de transporte e os critérios de cálculo;

(iii) os requisitos exigidos dos concorrentes e os critérios de pré-qualificação;

(iv) o período de exclusividade que terão os carregadores iniciais para exploração da capacidade contratada dos novos gasodutos de transporte;

(v) o prazo de duração da concessão e a possibilidade de prorrogação, quando for o caso (BRASIL, 2014a).

Através dos incisos do art. 17 acima referenciados, é possível verificar os elementos de planejamento que estão insertos no edital e no contrato de concessão, que validam os resultados das políticas e planos governamentais.

Por exemplo, a partir dos resultados levantados no PEMAT 2022, o MME lançará o edital que guarda as regras da licitação, assim como a respectiva minuta do contrato de concessão, delineada conforme os itens (i) a (vii), dentre outros constantes do art. 21. Dessa forma, o MME concretizará suas escolhas políticas.

Com a licitação, a empresa ou consórcio vencedor assinará o contrato de concessão com a identificação dos bens e instalações a serem considerados vinculados à sua exploração e prazo de duração de 30 anos, contado da data de sua assinatura. O prazo pode ser prorrogado no máximo por igual período, desde que requeridas pelo concessionário, no prazo de até 12 meses anteriores à data final do respectivo contrato, devendo a ANP manifestar-se sobre o requerimento em até 3 meses contados dessa data (BRASIL, 2014a).

As cláusulas do contrato de concessão devem conter, além das regras constantes do edital, conforme itens (i) a (vii), outros elementos tais como: 
(i) a relação dos bens e instalações destinados à exploração da atividade de transporte;

(ii) o cronograma de implantação, o investimento mínimo previsto e as hipóteses de expansão do gasoduto;

(iii) a receita anual e os critérios de reajuste;

(iv) as garantias prestadas;

(v) a especificação das regras sobre desocupação e devolução de áreas, inclusive retirada de equipamentos e incorporação de bens ao patrimônio da União;

(vi) os procedimentos para acompanhamento e fiscalização das atividades da concessionária e para a auditoria do contrato;

(vii) a obrigatoriedade de o concessionário fornecer à ANP relatórios, dados e informações relativos às atividades desenvolvidas;

(viii) as regras de acesso por qualquer carregador interessado;

(ix) as regras sobre solução de controvérsias;

(x) os casos de rescisão e extinção;

(xi) as penalidades aplicáveis na hipótese de descumprimento pelo concessionário das obrigações contratuais (BRASIL, 2014a).

Como visto, o contrato de concessão foi destinado a assegurar segurança jurídica através de regras claras, além de previsão de retorno do investimento aos carregadores iniciais por meio de período de exclusividade, bem como de tarifa que remunere os investimentos realizados.

Dessa forma, depreende-se que o contrato de concessão precedido de licitação refletirá o resultado do planejamento governamental.

\subsubsection{Da Autorização para Atividade de Transporte de Gás Natural}

Outro instrumento jurídico para entrada de empresas no segmento de transporte de gás natural é a autorização. Esse instrumento já era previsto na Lei do Petróleo.

Na Lei do Gás, o regime de autorização se manteve para gasodutos de transporte que envolvam acordos internacionais. Inclusive, foi previsto no art. 26 que o prazo de duração das novas autorizações será de 30 anos, prorrogáveis por igual período. Para ampliação será mantido seu regime e prazo remanescente (BRASIL, 2014a). 
$\mathrm{O}$ art. 28 tratou das tarifas para novos gasodutos objeto de autorização. Nesse caso, as tarifas serão propostas pelo transportador e aprovadas pela ANP, segundo seus critérios previamente estabelecidos (BRASIL, 2014a).

\subsubsection{Dos Gasodutos de Transporte Existentes}

No caso dos gasodutos já existentes sob o regime de autorização, regidos pela Lei do Petróleo, a Lei do Gás garantiu os direitos adquiridos, prescrevendo a ratificação das autorizações expedidas pela ANP. Igualmente, o art. 31 da Lei do Gás garante a preservação das tarifas de transporte e os critérios de revisão já definidos até a data da sua publicação (BRASIL, 2014a).

O prazo de duração da autorização é de 30 anos, contado da data de publicação desta Lei ou, para o caso dos empreendimentos em processo de licenciamento ambiental que, na data de publicação desta Lei, ainda não tenham obtido autorização da ANP, contado da data da outorga da autorização (BRASIL, 2014a).

O período de exclusividade que terão os carregadores iniciais será de 10 anos, contados do início da operação comercial do respectivo gasoduto de transporte (BRASIL, 2014a).

\subsubsection{Chamada Pública}

O procedimento de chamada pública promovido pela ANP, seguindo diretrizes da MME, também, exerce importante papel para a definição do planejamento setorial, pois precede a licitação e a assinatura do contrato de concessão.

Segundo redação do inciso VII, art. $2^{\circ}$, chamada pública é "procedimento, com garantia de acesso a todos os interessados, que tem por finalidade a contratação de capacidade de transporte em dutos existentes, a serem construídos ou ampliados" (BRASIL, 2014a).

Portanto, o objetivo da chamada pública é identificar potenciais carregadores e dimensionar a demanda efetiva para proporcionar aos órgãos governamentais a exata quantidade de agentes interessados na construção e ampliação de gasodutos.

Basicamente, a ANP fixa a tarifa máxima a ser aplicada aos carregadores interessados na contratação de capacidade de transporte. Os carregadores que solicitarem capacidade de transporte devem assinar um termo de compromisso de compra, 
irrevogável e irretratável, da capacidade solicitada, que fará parte integrante do edital de licitação (BRASIL, 2014a). Sendo assim, a ANP elabora o edital e o contrato de concessão também como decorrência do resultado da chamada pública (conforme ilustrado na Figura 2.4).

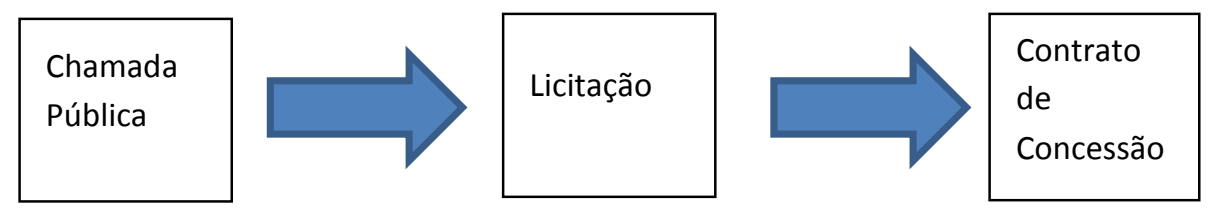

Figura 2.4 - Etapas do processo de entrada de agentes no segmeto de transporte de gás natural através de gasodutos

Fonte: Elaboração Própria

Portanto, ao se enxergar a Figura 2.4, entendendo cada etapa como integrante de um processo mais amplo, pode-se verificar que o planejamento precede todas essas etapas, sendo fundamental o papel do MME, conforme descrito no item 2.4.2.

\subsubsection{Funções do MME}

$\mathrm{O}$ art. $4^{\circ}$ da Lei do Gás delineia as competências do MME, todavia, ressalta-se que ao longo do texto da Lei é possível encontrar funções de forma esparsa (BRASIL, 2014a). Começando por esse dispositivo, enxerga-se as seguintes funções:

(i) propor, por iniciativa própria ou por provocação de terceiros, os gasodutos de transporte que deverão ser construídos ou ampliados;

(ii) estabelecer as diretrizes para o processo de contratação de capacidade de transporte;

(iii) definir o regime de concessão ou autorização (BRASIL, 2014a).

A partir da leitura das competências do MME, é possível verificar o fundamental papel que esse órgão da administração direta desempenha no segmento de transporte. Como se enxerga, gasodutos a serem construídos ou ampliados devem passar pelo crivo do MME, incluindo aqueles projetos de iniciativa de terceiros. 
Em outros termos, qualquer projeto de gasodutos no país somente se concretizará através de decisão do MME. Isso demonstra a total mudança de foco empreendida pela Lei do Gás comparativamente ao disposto na Lei do Petróleo.

Na Lei do Gás, o governo, agora, exerce um papel de dirigir a iniciativa privada, a denominada intervenção por indução, ou de intervenção direta, quando decide ele próprio construir. E, ao mesmo tempo, permite a própria iniciativa privada indicar quais projetos lhes interessa, o que se assemelha à Lei do Petróleo.

$\mathrm{Na}$ Lei do Petróleo, o governo absteve-se, deixando para a iniciativa privada o papel de direcionar suas intenções e solicitar as respectivas autorizações à ANP, quando assim entendesse.

Infere-se que, a Lei do Gás inaugura um novo modelo de planejamento setorial, ao incumbir o Poder Público, ou melhor, Poder Concedente, a atribuição de direcionar os esforços de construção ou ampliação de malhas por meio da intervenção direta ou por indução.

O inciso II do art. $4^{\circ}$ também demonstra o papel que o MME exerce em termos de chamada pública, momento em que os interessados carregadores indicarão para a ANP, qual a capacidade de transporte que pretendem contratar (BRASIL, 2014a). Sendo a partir disso que o próprio MME apontará a dimensão de gasodutos a serem construídos ou ampliados.

Igualmente, o MME tratará do regime jurídico a ser escolhido. Contudo, o MME deve seguir desde já os critérios determinados em lei, ou seja, concessão para gasodutos de interesse geral, e autorização para malhas oriundas de acordos internacionais.

Em termos de planejamento setorial focado no segmento de transporte de gás natural, pode-se verificar que o parágrafo primeiro do art. $4^{\circ}$ traz o ponto crucial para que o MME exerça sua prerrogativa de proposição de construção ou ampliação de gasodutos, qual seja, estudos de expansão da malha dutoviária do país (BRASIL, 2014a).

Inclusive, para viabilizar financeiramente a construção ou ampliação de gasodutos, a Lei do Gás prevê a utilização do instrumento de Parceria Público Privada $(\mathrm{PPP})^{13}$, quando o MME assim entender e justificar. Ou, caso considere mais adequando, a utilização de recursos provenientes da Contribuição de Intervenção no Domínio

\footnotetext{
${ }^{13}$ Lei n. 11.079, de 30 de dezembro de 2004, trata da PPP.
} 
Econômico (CIDE) e da Conta de Desenvolvimento Energético (CDE) ${ }^{14}$ (BRASIL, 2014a).

Esses tipos de instrumentos financeiro, PPP, CIDE e CDE, deverão ser utilizados quando se trata de gasodutos proposto por iniciativa do MME e diante de ato administrativo devidamente justificado por relevante interesse público. Isso implica que projetos provenientes de iniciativa privada deverão se concentrar em viabilizar gasodutos por outros tipos de instrumentos financeiros, eminentemente, conhecidos do setor privado.

O poder de planejamento destinado ao MME é tão significativo, que além dessa gama de decisões, o art. $7^{\circ}$ da Lei do Gás, ainda, permite que esse órgão modifique para mais a dimensão da capacidade de um gasoduto identificado na chamada pública, com o uso da PPP para viabilização econômico-financeira (BRASIL, 2014a).

Outras atribuições do MME, ao longo da Lei do Gás, serão tratadas nessa dissertação nos capítulos 3 e 4 .

\subsubsection{Dos agentes na Lei do Gás}

Além do MME, da ANP e do CNPE, a Lei do Gás também tratou de outros atores em seu texto. Para tanto, utiliza o termo agentes da indústria do gás natural para definir aquelas pessoas jurídicas que "atuam nas atividades de exploração, desenvolvimento, produção, importação, exportação, processamento, tratamento, transporte, carregamento, estocagem, acondicionamento, liquefação, regaseificação, distribuição e comercialização de gás natural" (art. $2^{\circ}$, inciso XXX) (BRASIL, 2014a).

Dessa forma, conceitua carregador como o agente interessado em "utilizar o serviço de movimentação de gás natural em gasoduto de transporte, mediante autorização da ANP" (art. 2º, inciso V) (Figura 6) (BRASIL, 2014a). Sendo que o carregador inicial é o agente que de alguma forma financiou economicamente a construção do gasoduto.

O transportador é “empresa autorizada ou concessionária da atividade de transporte de gás natural por meio de duto." (art. 2º inciso XXVI) (BRASIL, 2014a). A Tabela 2.1 traz as empresas de transporte em operação no país.

\footnotetext{
${ }^{14}$ Art. 13 da Lei no 10.438 , de 26 de abril de 2002.
} 
Tabela 2.1 - Transportadoras de gás natural em operação no Brasil

\begin{tabular}{cc} 
Transportadora & Participação Acionária \\
\hline \hline TAG & Gaspetro (100\%) \\
\hline TBG & $\begin{array}{c}\text { Gaspetro } \\
(51 \%), \text { BBPP Holding (29\%), Transredes (12\%) e } \\
\text { Ashmore Energy International (8\%) }\end{array}$ \\
$\begin{array}{c}\text { NTS Nova Transportadora do Nordeste } \\
\text { - NTN }\end{array}$ & $\begin{array}{c}\text { Mitsui (35\%), Mitsubishi (25\%), Itochu (25\%) e Tokyo Gas } \\
(15 \%)\end{array}$ \\
\hline TSB & $\begin{array}{c}\text { Gaspetro (25\%), TotalFinaElf (25\%), Ultrapar (20\%), } \\
\text { Repsol YPF (15\%) e TECGÁS (15\%) }\end{array}$ \\
\hline GasOcidente & Ashmore Energy International (100\%) \\
\hline GASENE & GASENE Participações Ltda. (100\%)
\end{tabular}

Fonte: MME (2011).

A exploração das atividades relativas ao transporte de gás natural, conforme disposto na Lei $\mathrm{n}^{\mathrm{o}} 11.909 / 2009$ (Artigo $1^{\mathrm{o}}, \S 2^{\circ}$ ), ocorrerá por conta e risco do empreendedor, não se constituindo, em qualquer hipótese, prestação de serviço público.

A Figura 2.5 traduz as relações contratuais que se formam entre transportador e carregador baseado no contrato de serviço de transporte, que pode ser de três tipos: (i) serviço de transporte extraordinário, modalidade de contratação de capacidade disponível, a qualquer tempo, com condição resolutiva, quando de contratação da capacidade na modalidade firme; (ii) serviço de transporte firme, no qual o transportador se obriga a programar e transportar o volume diário de gás natural até a capacidade contratada; e, (iii) serviço de transporte interruptivo, que poderá ser interrompido pelo transportador, diante de prioridade de programação do serviço de transporte firme (BRASIL, 2014a). 


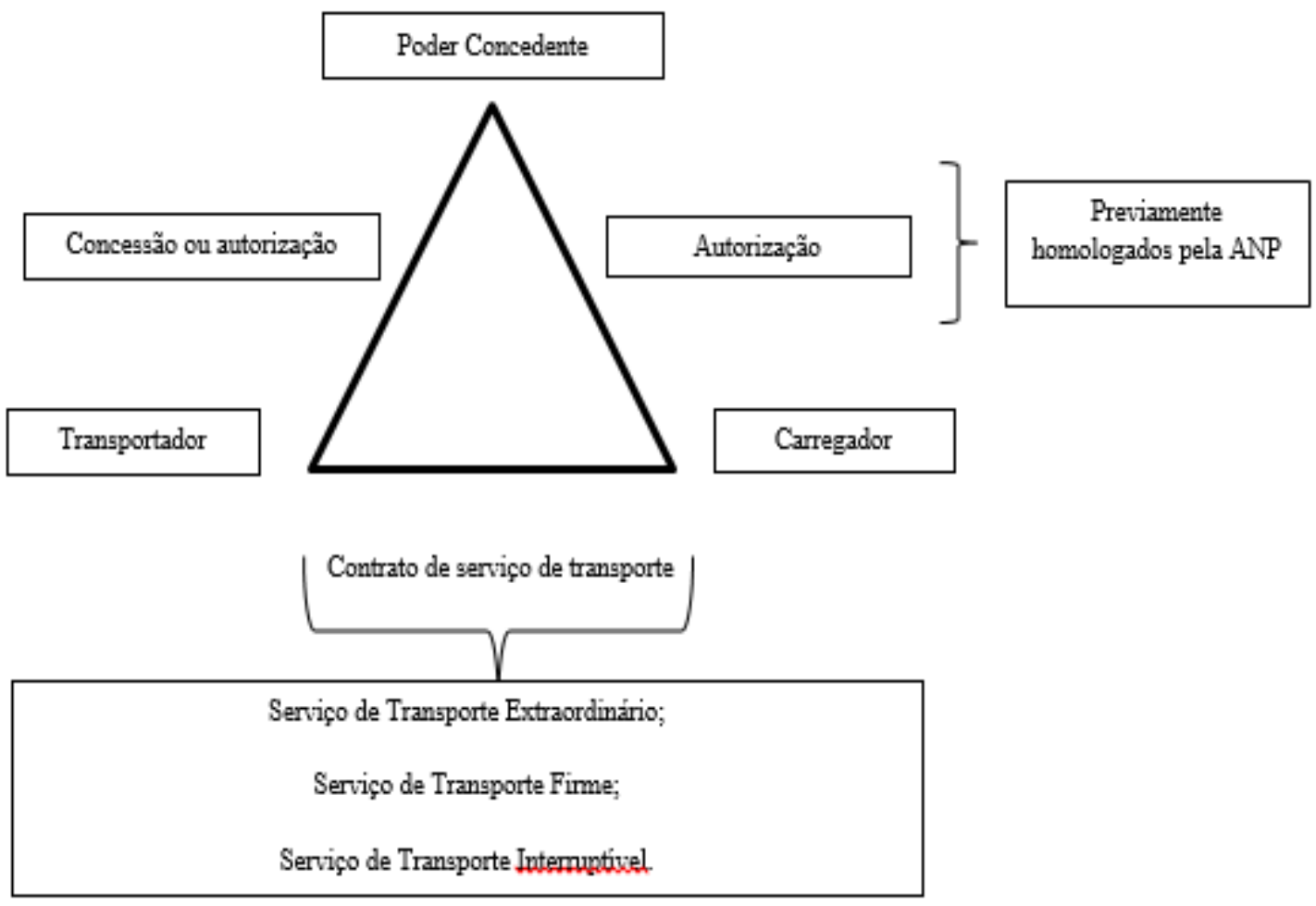

Figura 2.5 - Relações contratuais - transportador $x$ carregador: transportador $x$ poder concedente

Fonte: Elaboração Própria.

A relação jurídica entre transportador e carregador, portanto, é baseada em contratos de serviço, homologados previamente pela ANP (BRASIL, 2014a).

Contratualmente, o transportador também é concessionário ou autorizado (Figura 2.5, lado esquerdo). No primeiro caso, seguindo o disposto no art. 22 da Lei do Gás, constitui obrigação contratual do concessionário:

(i) celebrar com os carregadores contratos de transporte para todas as modalidades de serviço oferecidas, e previamente homologados pela ANP;

(ii) adotar, em todas as suas operações, as medidas necessárias para a preservação das instalações, das áreas ocupadas e dos recursos naturais, garantindo a segurança das populações e a proteção do meio ambiente;

(iii) estabelecer plano de emergência e contingência em face de acidentes, além de comunicar imediatamente o fato à ANP e às autoridades competentes;

(iv) responsabilizar-se civilmente pelos atos de seus prepostos e indenizar todos e quaisquer danos;

(v) adotar as melhores práticas da indústria internacional do gás; 
(vi) disponibilizar, em meio eletrônico, informações sobre as características de suas instalações, os serviços prestados, as tarifas aplicáveis, as capacidades disponíveis e os contratos celebrados (BRASIL, 2014a).

Além dessas relações jurídico-contratuais, o carregador também firmará contratos com distribuidoras ou consumidores livres. As distribuidoras, conforme trata o $\S 2^{\circ}$ do art. 25 da Constituição Federal, estabelecem contratos de concessão com os Estados, diante da competência estadual sobre os serviços locais de gás canalizado (BRASIL, 2014a).

O consumidor livre é aquele que tem a opção de adquirir o gás natural de qualquer agente produtor, importador ou comercializador, consumidor de gás natural que, seguindo legislação estadual aplicável (BRASIL, 2014a).

Os autoprodutores são agentes produtores de gás natural que utilizam sua produção como matéria-prima ou combustível. E, o auto-importador é aquele autorizado para a importação de gás natural que o utiliza como matéria-prima ou combustível em suas instalações industriais (BRASIL, 2014a).

A Lei do Gás referencia agentes autorizados para as atividades de construção, ampliação de capacidade e operação de unidades de processamento ou tratamento de gás natural (art. 43) (BRASIL, 2014a).

E, o art. 44 dispõe sobre os agentes autorizados para construir e operar unidades de liquefação e regaseificação de gás natural, bem como gasodutos de transferência e de escoamento da produção, não integrantes de concessão de exploração e produção de petróleo e gás natural (BRASIL, 2014a).

\subsubsection{Distribuição e comercialização}

Conforme ressaltado no item 2.4.3, a distribuição de gás natural canalizado prevista no $\S 2^{\circ}$ do art. 25 da Constituição Federal é uma atividade de competência estadual. Dessa forma, cada Estado deverá regular o assunto, não cabendo à Lei Federal extrapolar o âmbito de competência delineado na Constituição Federal. Cada Estado adota sua própria política em respeito ao segmento e, em cada Estado, vigora diferentes arranjos empresariais operados através de contratos de concessão específicos. A Figura 2.6 ilustra a distribuição nacional dessas empresas, enfatizando-se que em alguns Estados, São Paulo e Rio de Janeiro, convivem mais de um concessionário. 


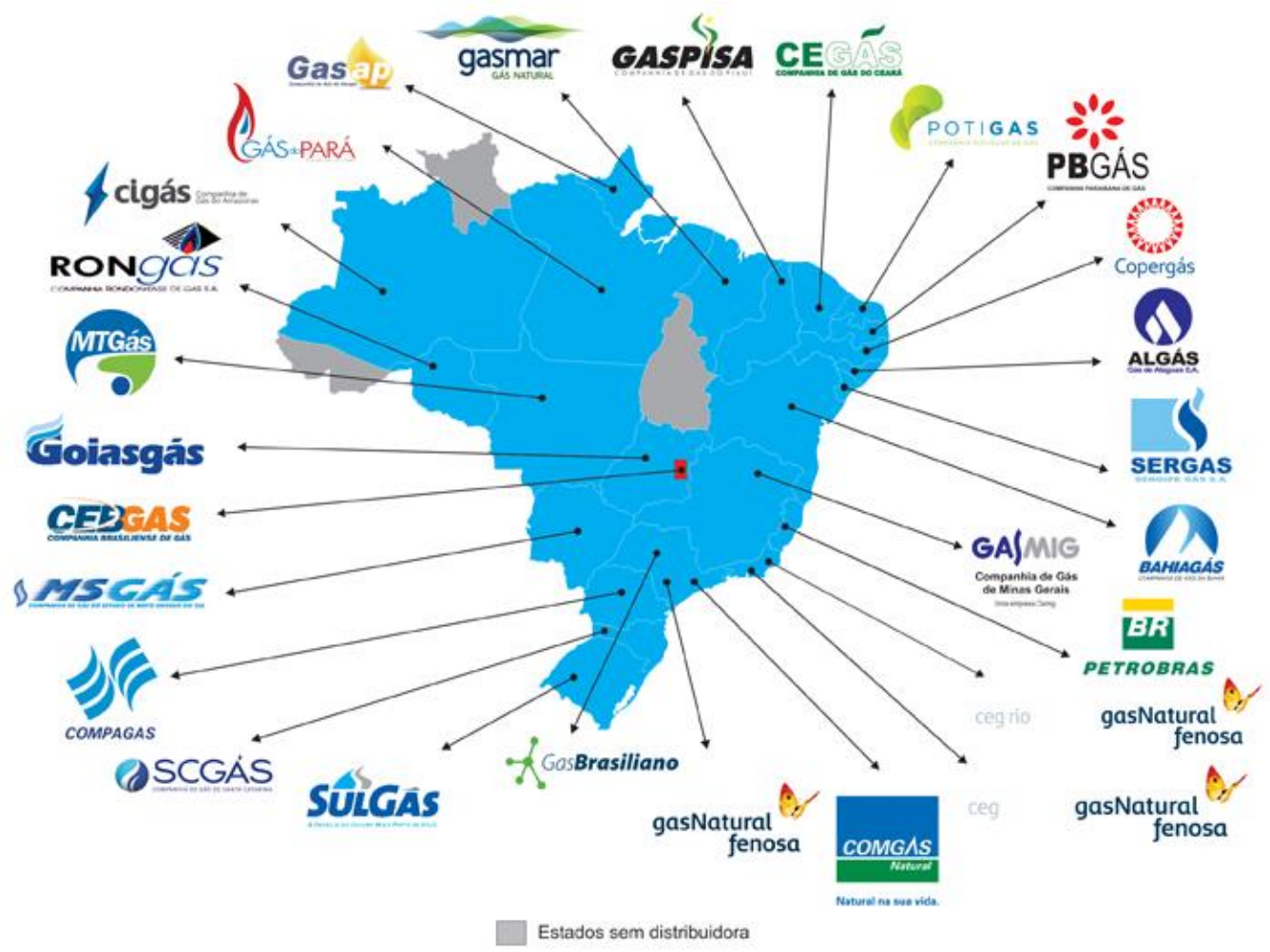

Figura 2.6 - Mapas das concessões de gás canalizado

Fonte: Abegás (2014).

Vale salientar que a Lei do Gás para não incorrer em inconstitucionalidade, prescreveu regras de cunho geral ou simplesmente repetiu o disposto na CF.

Conceitualmente, a distribuição de gás local é serviço público que destina gás aos diversos usuários finais, quais sejam, segmentos residencial, comercial, industrial, cogeração e gás natural veicular. A distribuidora será a responsável pela expansão da rede de dutos de baixa pressão, após os city gates.

O art. 46 da Lei do Gás abre uma exceção dessa regra de responsabilidade de expansão da rede de baixa pressão, quando a distribuidora estadual não possa atender a necessidades de consumidor livre, o autoprodutor ou o auto-importador (BRASIL, 2014a).

Nesse caso, esses agentes consumidores poderão expandir a rede "mediante celebração de contrato que atribua à distribuidora estadual a sua operação e manutenção, devendo as instalações e dutos ser incorporados ao patrimônio estadual mediante declaração de utilidade pública e justa e prévia indenização, quando de sua total utilização" (BRASIL, 2014a). 
Inclusive, enquanto papel de planejamento, a distribuidora estadual poderá solicitar que as instalações sejam dimensionadas de forma a viabilizar o atendimento a outros usuários, negociando com o consumidor livre, o autoprodutor ou o importador as contrapartidas necessárias, sob a arbitragem do órgão regulador estadual.

As tarifas de uso do sistema de distribuição serão estabelecidas pelo órgão regulador estadual resguardados os princípios da razoabilidade, transparência, publicidade e às especificidades de cada instalação (BRASIL, 2014a).

$\mathrm{Na}$ hipótese de instalações e os dutos construídos e implantados pelas distribuidoras estaduais, as tarifas são estabelecidas pelo órgão regulador estadual e devem cobrir os custos de investimento, operação e manutenção. $\mathrm{O}$ art. 47 ressalva o disposto no $\S 2^{\circ}$ do art. 25 da Constituição Federal, para possibilitar a comercialização de gás natural por meio de contratos registrados na ANP (BRASIL, 2014a).

A Tabela 2.2 traz os parâmetros comparativos entre a Lei do Petróleo e a Lei do Gás.

Tabela 2.2 - Quadro resumo lei do petróleo versus lei do gás

\begin{tabular}{|c|c|c|}
\hline Parâmetros & Lei 9478/97 (Lei do Petróleo) & Lei 11.909/09 (Lei do Gás) \\
\hline Acesso & Negociado entre as partes & $\begin{array}{l}\text { Para transporte firme, definido em } \\
\text { chamada pública. Para os transportes } \\
\text { interruptível e extraordinário, a serem } \\
\text { regulamentados pela ANP }\end{array}$ \\
\hline Tarifas de transporte & Negociado entre as partes & $\begin{array}{c}\text { Estabelecidas pela ANP nos casos de } \\
\text { concessão e aprovada nos casos de } \\
\text { autorização }\end{array}$ \\
\hline Estocagem & - & Concedida ou autorizada pela ANP \\
\hline Importação & Autorizada pela ANP & Autorizada pelo MME \\
\hline Comercialização & Livre & Autorizada pela ANP \\
\hline Contingência & - & $\begin{array}{l}\text { Supervisão pela ANP, da } \\
\text { movimentação de gás nas redes de } \\
\text { transporte. Ministério coordena Comitê } \\
\text { de Contingência. }\end{array}$ \\
\hline Transporte & Autorizado pela ANP & $\begin{array}{l}\text { Concedido pela ANP. Autorização da } \\
\text { ANP em casos particulares }\end{array}$ \\
\hline Qualidade do gás & Estabelecida pela ANP & Estabelecida pela ANP \\
\hline Contratos de transporte & $\begin{array}{l}\text { Enviados à ANP depois de } \\
\text { firmados }\end{array}$ & Aprovados previamente pela ANP \\
\hline Novos gasodutos & $\begin{array}{c}\text { Propostos pelos agentes de } \\
\text { mercados }\end{array}$ & Propostos pelo MME \\
\hline
\end{tabular}

Fonte: ANP (2012). 


\subsection{O Planejamento setorial}

Nos tópicos anteriores, focalizaram-se os aspectos relacionados ao planejamento do setor, relacionando-o com o segmento de transporte. Neste item 2.5, os delineamentos do planejamento são discutidos. O Dicionário Michaelis (2014) define planejamento como "2 Ato de projetar um trabalho, serviço ou mais complexo empreendimento. 3 Determinação dos objetivos ou metas de um empreendimento, como também da coordenação de meios e recursos para atingi-los; planificação de serviços. 4 Dependência de uma indústria ou repartição pública, com o encargo de planejar serviços."

O governo realizará o planejamento seguindo o disposto no art. 174 da Constituição Federal, que reza: "como agente normativo e regulador da atividade econômica, o Estado exercerá, na forma da lei, as funções de fiscalização, incentivo e planejamento, sendo este determinante para o setor público e indicativo para o setor privado" (BRASIL, 2014f).

Para Dantas (2014, p. 136), o planejamento do Estado é o principal instrumento para a promoção do bem estar social. Com isso, o planejamento "deve ter como objetivos, princípios e limites aqueles impostos pela constituição enquanto carta político-jurídica.”

Pela importância que se reveste, o planejamento, inclusive, necessita ser previamente analisado para fins de averiguação de seus resultados. O intuito da verificação de seus efeitos se deve à relevância do exame da coerência entre a norma e a realidade, que essa poderá criar com objetivo de que a sua atuação na esfera econômica não gere maiores problemas do que aqueles que a ação estatal se dispõe a resolver, a construir e a desenvolver (Dantas, 2014, p. 136).

Para realizar o planejamento, especificamente, no setor de gás natural, historicamente, o governo lançou mão, em 1987, do Plano Nacional do Gás Natural (PNGN), que visava o incremento do uso desse energético na matriz nacional. Igualmente, com o objetivo de diversificação da matriz e diminuição da dependência do país à geração hidroelétrica, em 1991, novos estudos foram conduzidos em âmbito federal e resultaram na formalização da meta governamental de aumentar a participação do gás natural na matriz energética. para $12 \%$ até 2010 (Costa e Santos, 2006) ${ }^{15}$ (vide Tabela 2.3).

\footnotetext{
${ }^{15}$ Registra-se a Portaria $n^{\circ} 1.061$, de 08 de agosto de 1986, do Ministério de Minas e Energia, que dispôs sobre a produção, transporte, distribuição, consumo, importação e exportação de gás natural, surgiu exatamente da necessidade de uma norma própria, para dar pleno aproveitamento às reservas e para
} 
Tabela 2.3 - Histórico da participação do gás natural na matriz energética brasileira

\begin{tabular}{|c|c|c|c|c|c|c|c|c|}
\hline & $\begin{array}{c}\text { Petró } \\
\text { leo }\end{array}$ & $\begin{array}{c}\text { Gás } \\
\text { Natural }\end{array}$ & $\begin{array}{l}\text { Hidráu- } \\
\text { lica e } \\
\text { Eletrici- } \\
\text { dade }\end{array}$ & $\begin{array}{c}\text { Lenha e } \\
\text { Carvão } \\
\text { Vegetal }\end{array}$ & $\begin{array}{c}\text { Deriva- } \\
\text { dos de } \\
\text { cana }\end{array}$ & $\begin{array}{c}\text { Carvão } \\
\text { mineral } \\
\text { e coque }\end{array}$ & Urânio & $\begin{array}{c}\text { Outras } \\
\text { renová- } \\
\text { veis }\end{array}$ \\
\hline 2000 & 45,5 & 5,4 & 15,7 & 12,1 & 10,9 & 7,1 & 0,9 & 2,3 \\
\hline 2001 & 45,4 & 6,5 & 13,6 & 11,6 & 11,8 & 6,9 & 2,0 & 2,4 \\
\hline 2002 & 43,0 & 7,4 & 14,0 & 11,9 & 12,8 & 6,5 & 1,9 & 2,5 \\
\hline 2003 & 40,1 & 7,7 & 14,6 & 12,9 & 13,4 & 6,7 & 1,8 & 2,8 \\
\hline 2004 & 39,1 & 8,9 & 14,4 & 13,2 & 13,5 & 6,7 & 1,5 & 2,7 \\
\hline 2005 & 38,7 & 9,4 & 14,8 & 13,0 & 13,8 & 6,3 & 1,2 & 2,9 \\
\hline 2006 & 37,8 & 9,6 & 14,8 & 12,6 & 14,6 & 6,0 & 1,6 & 3,0 \\
\hline 2007 & 37,5 & 6,3 & 14,9 & 12,0 & 15,9 & 6,0 & 1,4 & 2,9 \\
\hline 2008 & 36,6 & 10,3 & 14,0 & 11,6 & 17,0 & 5,8 & 1,5 & 3,4 \\
\hline 2009 & 37,9 & 8,7 & 15,2 & 10,1 & 18,2 & 4,7 & 1,4 & 3,8 \\
\hline 2010 & 37,7 & 10,3 & 14,1 & 9,5 & 17,7 & 5,2 & 1,4 & 4,0 \\
\hline 2011 & 38,7 & 10,2 & 14,7 & 9,2 & 16,1 & 5,6 & 1,5 & 4,0 \\
\hline
\end{tabular}

Fonte: MME, 2012

Em setembro de 1999, o governo federal implantou o Plano Prioritário de Termoeletricidade (PPT), que tinha como objetivo principal incentivar investimentos do setor privado em geração de energia térmica a gás natural a fim de reduzir a dependência

regulamentar o transporte, a distribuição e o consumo desse energético para fins residenciais, comerciais, industriais etc. 
do sistema elétrico nacional às condições hidrológicas e reduzir a vulnerabilidade do sistema de transmissão brasileiro (Rechelo Neto, 2005).

Com a construção do gasoduto Bolívia-Brasil (GASBOL), a Petrobrás garantiu o fornecimento de gás para o PPT e exercitou a opção de compra do gás natural adicional previsto no contrato de compra e venda com a Yacimientos Petrolíferos Fiscales Bolivianos (YPFB), ampliando dessa forma o volume previamente contratado de 24 milhões de m3/dia em 2003 para 30 milhões de m3/dia em 2004 (Costa e Santos, 2006). Inicialmente o PPT identificou 15 projetos prioritários a serem implementados até 2003, gerando num total de $12 \mathrm{GW}$ de capacidade instalada. Posteriormente, o PPT foi expandido para 51 plantas com capacidade conjunta instalada de $22 \mathrm{GW}$, atendendo interesses de autoridades locais e investidores privados. Hoje, o gás natural destinado ao setor termoelétrico cresce de forma significativa, conforme pode ser visto nas Tabela 2.4 e na Tabela 2.5 .

Tabela 2.4 - Consumo de gás natural por segmento

\begin{tabular}{|c|c|c|c|c|c|c|c|}
\hline \multirow{2}{*}{$\begin{array}{l}\text { CONSUMO DE GÁS } \\
\text { NATURAL POR SETOR } \\
\text { (milhões de m³/dia) }\end{array}$} & \multicolumn{6}{|c|}{ Média } & \multirow[b]{2}{*}{ 2014/ Média \% } \\
\hline & 2009 & 2010 & 2011 & 2012 & 2013 & 2014 & \\
\hline Industrial * & 28,96 & 35,41 & 40,85 & 41,82 & 41,27 & 43,06 & 43,4 \\
\hline Automotivo & 5,77 & 5,5 & 5,4 & 5,32 & 5,13 & 4,93 & 5 \\
\hline Residencial & 0,74 & 0,79 & 0,87 & 0,92 & 1 & 0,97 & 1 \\
\hline Comercial & 0,59 & 0,63 & 0,68 & 0,72 & 0,75 & 0,76 & 0,8 \\
\hline $\begin{array}{c}\text { Geração de Energia } \\
\text { Elétrica * }\end{array}$ & 5,31 & 15,77 & 10,42 & 23,03 & 38,92 & 46,78 & 47,2 \\
\hline Co-geração & 2,43 & 2,9 & 3,01 & 2,92 & 2,46 & 2,56 & 2,6 \\
\hline Outros (inclui GNC) & 0,64 & 0,68 & 0,17 & 0,11 & 0,1 & 0,06 & 0,1 \\
\hline TOTAL & 44,44 & 61,69 & 61,4 & 74,84 & 89,64 & 99,13 & 100 \\
\hline $\begin{array}{l}\text { Consumo nas unidades de } \\
\text { E\&P, absorção em } \\
\text { UPGNs (GLP, C5+) e } \\
\text { Consumo em transporte e } \\
\text { armazenamento / Ajustes }\end{array}$ & 14,51 & 16,2 & 16,22 & 17,22 & 18,65 & 18,55 & \\
\hline TOTAL GERAL & $\mathbf{5 8 , 9 5}$ & $\mathbf{7 7 , 8 9}$ & 77,62 & 92,07 & 108,29 & 117,68 & \\
\hline
\end{tabular}


Tabela 2.5 - Balanço de gás natural no Brasil

\begin{tabular}{|c|c|c|c|c|c|c|}
\hline $\begin{array}{l}\text { BALANÇO DE GÁS NATURAL } \\
\text { (em milhões de } \text { mª }^{3} \text { dia) }\end{array}$ & $\begin{array}{c}\text { Média } \\
2009\end{array}$ & $\begin{array}{c}\text { Média } \\
2010\end{array}$ & $\begin{array}{c}\text { Média } \\
2011 \\
\end{array}$ & $\begin{array}{c}\text { Média } \\
2012 \\
\end{array}$ & $\begin{array}{c}\text { Média } \\
2013 \\
\end{array}$ & $\begin{array}{c}\text { Média } \\
2014\end{array}$ \\
\hline PRODUÇÃO NACIONAL & 57,91 & 62,84 & 65,93 & $\mathbf{7 0 , 5 8}$ & 77,19 & 85,43 \\
\hline Reinjeção & 11,92 & 12,53 & 11,07 & 9,68 & 10,64 & 15,08 \\
\hline Queima e perda & 9,38 & 6,64 & 4,81 & 3,95 & 3,57 & 4,45 \\
\hline Consumo nas unidades de E\&P & 8,45 & 9,72 & 10,15 & 10,57 & 10,85 & 11,27 \\
\hline $\begin{array}{c}\text { Consumo em transporte e armazenamento } \\
\text { Ajustes }\end{array}$ & 2,67 & 2,35 & 2,64 & 3,14 & 4,24 & 3,81 \\
\hline Absorção em UPGNs (GLP, C5+) & 3,39 & 3,56 & 3,43 & 3,52 & 3,56 & 3,47 \\
\hline Oferta de gás nacional ao mercado & 22,1 & 28,04 & 33,83 & 39,73 & 44,33 & 47,34 \\
\hline IMPORTAÇÃO & 22,92 & $\mathbf{3 4 , 5 5}$ & 28,5 & 36,04 & 46,47 & 53,03 \\
\hline Bolívia & 22,2 & 26,91 & 26,86 & 27,54 & 31,75 & 33,11 \\
\hline Argentina & 0 & 0 & 0 & 0 & 0,16 & 0,25 \\
\hline Gás Natural Liquefeito - GNL * & 0,72 & 7,64 & 1,64 & 8,5 & 14,56 & 19,68 \\
\hline Consumo em transporte na importação & 0,58 & 0,89 & 0,93 & 0,93 & 1,17 & 1,24 \\
\hline Oferta de gás importado ao mercado & 22,35 & 33,66 & 27,57 & 35,11 & 45,31 & 51,79 \\
\hline OFERTA TOTAL AO MERCADO & 44,45 & 61,7 & 61,4 & $\mathbf{7 4 , 8 4}$ & 89,64 & 99,13 \\
\hline Venda nas distribuidoras de gás natural & 36,7 & 49,73 & 47,67 & 57,12 & 66,9 & 72,91 \\
\hline $\begin{array}{c}\text { Consumo instalações industriais produtor } \\
\text { (Refinarias/FAFENS) }\end{array}$ & 7,09 & 9,12 & 11,28 & 12,69 & 12,48 & 13,87 \\
\hline $\begin{array}{l}\text { Consumos termelétricos direto do produtor e de } \\
\text { Consumidores Livres (Celso Furtado/Rômulo } \\
\text { Almeida/Canoas/Termoceará/Termoaçú/Euzébio } \\
\text { Rocha/ Cuiabá / Maranhão IV e V) }\end{array}$ & 0,66 & 2,84 & 2,46 & 5,03 & 10,26 & 12,35 \\
\hline $\begin{array}{c}\text { PARTICIPAÇÃO DO GÁS NACIONAL NA } \\
\text { OFERTA TOTAL AO MERCADO }(\%)\end{array}$ & $49,70 \%$ & $45,40 \%$ & $55,10 \%$ & $53,90 \%$ & $49,50 \%$ & $47,80 \%$ \\
\hline
\end{tabular}

Fonte: MME, 2014, a partir de ANP, ABEGAS, TSB e PETROBRAS.

O reflexo da política do PPT é de longo prazo, sobretudo, por causa dos preços avençados. Salienta-se que os preços aplicados ao PPT são distintos de outros valores do gás nacional e do gás importado da Bolívia e GNL.

A Tabela 2.6 traz os preços nacionais e importado da Bolívia; a Tabela 2.7 mostra os preços do PPT. 
Tabela 2.6 - Preços referência no Brasil - outubro/2014

Preço Petrobras para Distribuidora

(Preços isentos de tributos e encargos)

\begin{tabular}{|c|c|c|c|c|c|c|c|}
\hline \multirow{3}{*}{ Região } & \multirow{3}{*}{ Contratos } & & & & \multicolumn{3}{|c|}{ (em US\$/MIVIB 1 U c/ Impostos) } \\
\hline & & \multicolumn{3}{|c|}{ Preço (US\$/MMBTU) } & 2.000 & 20.000 & 50.000 \\
\hline & & \multicolumn{2}{|c|}{ sem desconto co } & desconto & $\mathrm{m}^{3} / \mathrm{dia}$ & $\mathbf{m}^{3} /$ dia & $\mathrm{m}^{3} / \mathrm{dia}$ \\
\hline Nordeste & $\begin{array}{c}\text { Nova } \\
\text { Política } \\
\text { Modalidade } \\
\text { Firme }\end{array}$ & \multicolumn{2}{|c|}{12,8669} & 8,4921 & 14,1291 & 15,8312 & 15,4194 \\
\hline Sudeste & $\begin{array}{c}\text { Nova } \\
\text { Política } \\
\text { Modalidade } \\
\text { Firme }\end{array}$ & \multicolumn{2}{|c|}{12,8671} & 8,4923 & 19,1150 & 15,7631 & 15,0522 \\
\hline \multirow{2}{*}{ Região } & \multirow{2}{*}{ Contratos } & \multicolumn{3}{|c|}{ Preço (US\$/MMBTU) } & 2.000 & 20.000 & $\mathbf{5 0 . 0 0 0}$ \\
\hline & & Commodity & Transporte & Total & $\mathrm{m}^{3} / \mathrm{dia}$ & $\mathrm{m}^{3} / \mathrm{dia}$ & $\mathrm{m}^{3} / \mathrm{dia}$ \\
\hline Sudeste & $\begin{array}{c}\text { Gás } \\
\text { Importado }\end{array}$ & 8,1394 & 1,8020 & 9,9413 & 19,1150 & 15,7631 & 15,0522 \\
\hline Sul & $\begin{array}{c}\text { Gás } \\
\text { Importado }\end{array}$ & 8,1213 & 1,7983 & 9,9196 & 19,8159 & 17,9648 & 17,5779 \\
\hline $\begin{array}{c}\text { Centro } \\
\text { Oeste }\end{array}$ & $\begin{array}{c}\text { Gás } \\
\text { Importado }\end{array}$ & 9,3189 & 1,8385 & 11,1574 & 17,7658 & 15,1424 & 0,0000 \\
\hline
\end{tabular}

Fonte: MME/SPG/DGN, out/14.

* Dados originalmente obtidos da Petrobras, Distribuidoras e Banco Central. Médias regionais simples (não ponderadas por volume).

* Os preços ao consumidor final do segmento industrial foram calculados pelo MME com base nas informações de preço disponibilizadas nos sítios das distribuidoras ou das agências reguladoras estaduais.

* $\quad$ Segundo a Petrobras, a seu exclusivo critério, no mês de setembro/14 foi aplicado um desconto provisório equivalente a $34 \%$ sobre os preços contratuais da nova política de modalidade firme para as distribuidoras das regiões Nordeste e Sudeste.

Dólar de conversão R\$/US\$ (setembro/14):

2,3329

Fonte: MME, 2014.

Tabela 2.7 - Preços PPT

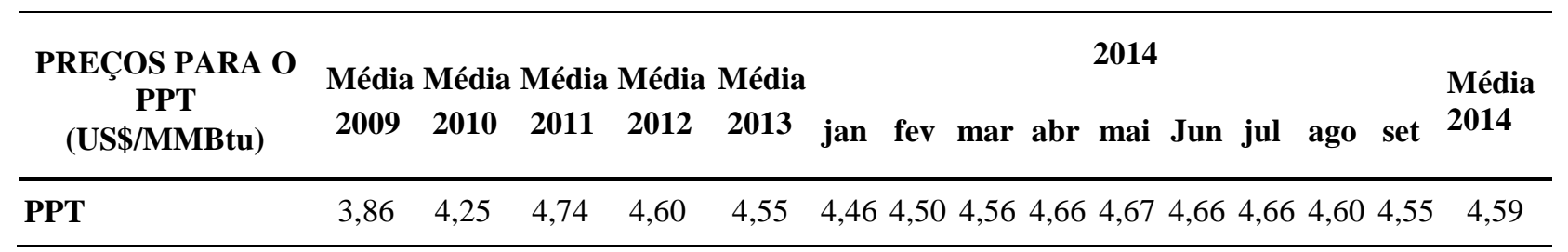

Fonte: MME, 2014.

Segundo o MME (2014, p. 21), “o preço do gás natural para o PPT não inclui imposto e é calculado com base na Portaria Interministerial n ${ }^{\circ} 234 / 02 . "$ 
Assume-se, portanto, que o planejamento setorial direcionou, dado o preço e diante dos resultados de consumo, o crescimento da demanda do gás natural baseado no segmento termoelétrico, o que será discutido de forma mais ampla nos Capítulos 3 e 4 .

\subsection{Considerações finais do capítulo}

Nesse capítulo foi possível averiguar a mudança de perspectiva da Lei do Petróleo para a Lei do Gás no tocante ao segmento de transporte de gás. Da autorização para a concessão, além de alteração de regime jurídico, ocorreram importantes inovações que tornaram o segmento de transporte extremamente complexo e pautado no planejamento governamental.

Com isso, percebe-se que análises do setor de gás necessitam, igualmente, focalizar a evolução do planejamento setorial da Lei do Petróleo a Lei do Gás. Através desses diplomas, foi possível visualizar as funções do CNPE, da ANP e do MME, em que o planejamento exerce, a partir da Lei do Gás, um papel significativo no segmento de transporte de gás natural.

Dessa forma, o MME, por meio de instrumentos jurídicos criados pela Lei do Gás, atuará no setor do gás, em diversas etapas até a assinatura final do contrato de concessão, desde à proposição de projetos de gasodutos ao lançamento de diretrizes que compreenderá a licitação.

Ao longo do capítulo, apreendeu-se que a Lei do Gás inovou, pois trouxe para o país um novo modelo de planejamento setorial, ao incumbir o Poder Concedente, da atribuição de direcionar os esforços de construção ou ampliação de malhas por meio da intervenção direta ou por indução à atividade da iniciativa privada.

Nesse sentido, o capítulo seguinte apresenta o Plano Decenal de Expansão da Malha Dutoviária de Transporte de Gás Natural (PEMAT), instrumento básico de planejamento do setorial e objeto do estudo de caso da presente dissertação. 


\section{ESTUDO DE CASO: PEMAT 2022}

\subsection{Introdução}

Os próximos parágrafos têm como referência o plano decenal de expansão da malha de transporte dutoviário - PEMAT 2013-2022. (EPE, 2014)

Conforme tratado no capítulo 2, a Lei no 11.909 (Lei do Gás), regulamentada pelo Decreto $\mathrm{n}^{\circ} 7.382$, de 2 de dezembro de 20106, contém as bases para a expansão do mercado brasileiro de gás natural. Resultado do debate entre diversos agentes do setor, além dos Poderes Executivo e Legislativo o referido marco legal trata as especificidades da indústria do gás natural. O papel do MME como poder concedente e formulador das políticas públicas para o setor do gás natural foi reforçado ao atribuir-lhe a responsabilidade pela elaboração do Plano Decenal de Expansão da Malha Dutoviária de Transporte de Gás Natural - PEMAT, desenvolvido pela Empresa de Pesquisa Energética (EPE).

Nesse sentido, o presente capítulo apresenta no item 3.2 o papel da EPE em termos de planejamento setorial, com foco na construção e na elaboração do PEMAT em estudo. Do tópico 3.3 e seus subsequentes itens, aborda-se a composição do PEMAT em si, com a descrição da metodologia utilizada pela EPE e a apresentação dos resultados em cada etapa desenvolvida no estudo. O item 3.8 trata dos resultados de cada etapa do processo de estudos de alternativas. Finalmente, no item 3.9, considerações finais desse capítulo são tecidas.

\subsection{A Empresa de Pesquisa Energética (EPE) e o planejamento setorial}

O PEMAT tem como base estudos desenvolvidos pela $\mathrm{EPE}^{16}$. Tais estudos devem apresentar as necessidades de construção de novos gasodutos, assim como de ampliação da infraestrutura existente, com o objetivo de identificar as alternativas viáveis,

\footnotetext{
${ }^{16}$ A EPE foi criada pela Lei n. 10.847, de 15 de março de 2004. Segundo o art. $2^{\circ}$ dessa Lei, a EPE tem por finalidade prestar serviços na área de estudos e pesquisas destinadas a subsidiar o planejamento do setor energético, tais como energia elétrica, petróleo e gás natural e seus derivados, carvão mineral, fontes energéticas renováveis e eficiência energética, dentre outras. Dentre as atribuições da EPE com foco na indústria do gás natural ressaltam-se os seguintes incisos do art. 4": "VIII - promover estudos para dar suporte ao gerenciamento da relação reserva e produção de hidrocarbonetos no Brasil, visando à autosuficiência sustentável; XII - elaborar estudos relativos ao plano diretor para o desenvolvimento da indústria de gás natural no Brasil”.
} 
considerando os aspectos econômicos, técnicos e socioambientais para a expansão da malha de gasodutos.

A EPE deve apresentar anualmente estudos referentes à expansão e à ampliação da malha de transporte tomando como base estudos concernentes a planejamentos regionais, estudos de mercado e consultas aos agentes da indústria de gás natural.

O produto destes estudos será ponto de partida para a elaboração do PEMAT, que deverá contemplar as oportunidades e apresentar as características técnicas dos gasodutos, que viabilizem o acesso aos mercados demandantes de gás natural.

Serão avaliadas alternativas propostas pelo próprio MME e proposições feitas por terceiros, neste caso, a abordagem deve ter o detalhamento de projeto de infraestrutura compatível com o de gasoduto de referência, conforme estabelecido na Portaria MME ${ }^{\circ}$ 94, de 04 de março de 2012 (EPE, 2014).

Assim a EPE realiza os estudos e emite relatório sobre a provocação de terceiros a partir de um requerimento de projeto para construção ou ampliação de gasoduto de transporte com maior nível de detalhamento e menor grau de incerteza em relação ao dos estudos por iniciativa própria do MME (EPE, 2014).

O MME instituirá um Comitê de Validação para corroborar, dentre as alternativas identificadas nos estudos da EPE, aquelas que devem ser propostas pelo MME em função de considerações traçadas pelos agentes da indústria de gás natural quanto às opções de uso do gás natural e ao seu preço de realização (EPE, 2014). Ou seja, caberá a esse Comitê verificar se há interesse por parte dos ofertantes de gás natural pelas alternativas de gasoduto identificadas nos estudos da EPE.

Neste sentido, a Figura 3.1 traz o “Arcabouço Institucional da Lei do Gás Natural” com as etapas regulamentadas pela Lei do Gás as quais determinam o processo final de seleção para a determinação de projetos que estarão sujeitos à licitação. 


\begin{tabular}{|c|c|c|c|c|c|c|}
\hline \multicolumn{3}{|c|}{ Planejamento } & \multicolumn{2}{|c|}{ Chamada Pública } & \multicolumn{2}{|c|}{ Licitação } \\
\hline $\begin{array}{l}\text { Elabora os } \\
\text { estudos } \\
\text { de } \\
\text { expansão } \\
\text { da malha }\end{array}$ & $\begin{array}{l}\text { Publica o } \\
\text { PEMAT }\end{array}$ & $\begin{array}{l}\text { Propõe os } \\
\text { gasodutos } \\
\text { que serão } \\
\text { construídos } \\
\text { ou } \\
\text { ampliados }\end{array}$ & $\begin{array}{l}\text { Publica } \\
\text { Diretrizes } \\
\text { para } 0 \\
\text { processo } \\
\text { de } \\
\text { chamada } \\
\text { pública }\end{array}$ & $\begin{array}{l}\text { Realiza } \\
\text { Processo } \\
\text { de } \\
\text { Chamada } \\
\text { Pública }\end{array}$ & $\begin{array}{l}\text { Publica } \\
\text { diretrizes } \\
\text { para } 0 \\
\text { processo } \\
\text { Licitatório }\end{array}$ & $\begin{array}{l}\text { Elabora } \\
\text { editais e } \\
\text { contratos, } \\
\text { e realiza } \\
\text { processo } \\
\text { Licitatório }\end{array}$ \\
\hline
\end{tabular}

Figura 3.1 - Arcabouço Institucional da Lei do Gás

Fonte: ARAÚJO e CECCHI (2011)

Diante dessas considerações, resta apontar o conceito do PEMAT delineado no próprio documento:

"O PEMAT é um instrumento que busca identificar alternativas de gasodutos de transporte de gás natural que sejam elegíveis à proposição pelo MME, estando seu escopo integrado aos demais instrumentos de planejamento do setor energético nacional, entre eles o PDE, o Plano Nacional de Energia (PNE) e, ainda, o Zoneamento Nacional de Recursos de Óleo e Gás." (EPE, 2014, p. 15).

\subsection{Avaliação das proposições por terceiros}

Como já citado no capítulo 2, o art. $4^{\circ}$, inciso I, da Lei n ${ }^{\circ} 11.909 / 2009$, trata da iniciativa de propostas de gasodutos de transporte por terceiros interessados. Os procedimentos para estas proposições foram estabelecidos pela Portaria MME $\mathrm{n}^{\mathbf{o}}$ 94/2012; onde o agente interessado entra com requerimento de construção ou ampliação de gasodutos de transporte, entre $1^{\circ}$ de janeiro e 31 de março de cada ano, ou a qualquer tempo, em caso de urgência (EPE, 2014).

Para avaliar estas proposições, a EPE definiu um processo de avaliação, envolvendo cinco etapas distintas como é ilustrado na Figura 3.2. Como pode-se observar a etapa 1 consiste na análise da documentação do requerimento de Provocação de Terceiros protocolizada no $\mathrm{MME}^{17}$ (EPE, 2014).

\footnotetext{
${ }^{17}$ Avalia-se a fundamentação da proposta em relação à: Identificação do agente provocador e dados básicos do empreendimento; Demonstração de demanda potencial; Demonstração de disponibilidade de oferta de gás natural para o atendimento da demanda identificada; Características e custos de investimentos do
} 
Etapa 1: Analisar a documentação do Requerimento de Provocaçăo de Terceiros protocolizada no MME visando à realização de estudos e à emissão de relatório pela EPE

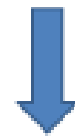

Etapa 2: Avaliar as informações, premissas e estimativas do Projeto de Provocação de Terceiros com base em estudos próprios realizados pela EPE

Etapa 3: Solicitar esclarecimentos no caso de haver discrepâncias significativas entre o projeto de provocaçăo de Terceiros e os estudos proprios da EPE

Etapa 4: Avaliar os impactos do gasoduto proposto sobre a malha de transporte dutoviário e a conveniência da construção ou ampliação proposta

Etapa 5: Emitir relatório da EPE sobre o Requerimento de Provocação de Terceiros e eventuais esclarecimentos prestados pelo Agente Provocador, conforme estabelecido na Portaria MME n: 94/2012

\section{Figura 3.2 - Processo de avaliação pela EPE de requerimento de provocação de terceiros}

Fonte: PEMAT 2022 (EPE,2014)

$\mathrm{Na}$ etapa 2, a fundamentação do projeto é contestada com os estudos da EPE. Nesse estágio, avaliam-se as premissas, estimativas e informações, especialmente, as estimativas de custos de investimento realizadas pelo Sistema de Avaliação de Gasodutos

gasoduto, assim como os custos administrativos e de operação e manutenção; Cronograma físico-financeiro estimado do projeto; Cronograma físico-financeiro de expansão planejada de capacidade do gasoduto (inclusive desembolso dos principais componentes de custo); Caracterização e análise socioambiental da área abrangida pelo empreendimento; Comprovação de urgência do projeto (para proposta enviadas fora do período determinado pela portaria MME no 94/2012. 
de Transporte (SAGAS) e de seus estudos de viabilidade técnica e econômica (EPE, 2014).

A etapa 3 somente será executada caso apareçam discrepâncias na etapa 2, e, neste caso, solicitar-se-ão esclarecimentos. A etapa 4 consiste na avaliação dos impactos do gasoduto na malha de transporte dutoviária existente, assim como na "conveniência" do projeto. Finalmente, a etapa 5 consiste na emissão do parecer da EPE em relação às provocações.

\subsection{Critérios para Avaliação de Alternativas para o PEMAT 2022}

A Figura 3.16 é a representação do processo, cujo o objetivo é definir as alternativas para os estudos do PEMAT 2022. Como pode-se observar, o processo é elaborado pela EPE e se inicia com as caracterizações da oferta e demanda potenciais brasileiras de gás natural no horizonte decenal, que compreende o ciclo do PEMAT 2022 (EPE, 2014).

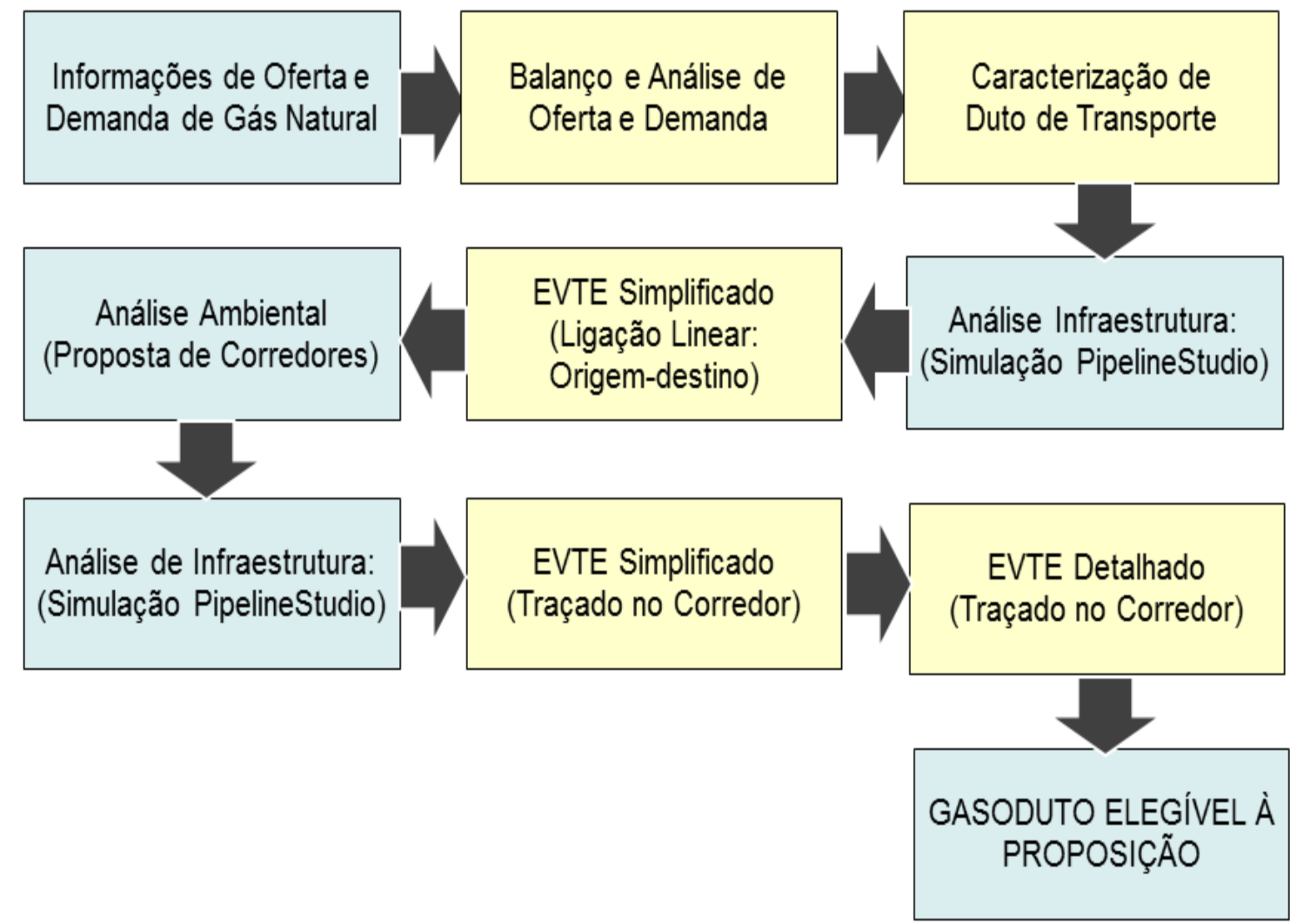

Figura 3.3 - Processos de definição das alternativas de gasodutos de transporte nos estudos 
Neste processo, o que inicialmente orienta a proposição de uma alternativa é a possibilidade de demanda por gás natural em determinada área de influência regional e, posteriormente a confirmação da possibilidade de oferta para seu atendimento (EPE, 2014).

Nas premissas da EPE há também a necessidade de se avaliar o balanço preliminar de oferta e demanda potenciais de gás natural no sistema em questão, que, dependendo da localidade, pode ser o sistema isolado ou a malha integrada. Assim confirma-se que o atendimento das opções de ligação esteja consonante com as projeções de disponibilidade de gás natural.

Confirmada a disponibilidade de oferta para o atendimento da demanda ${ }^{18}$ é definida uma alternativa para avaliação. Inicialmente, o traçado é um segmento de reta entre os pontos de oferta potencial e demanda potencial. É importante determinar se a alternativa pode ser caracterizada como gasoduto de transporte, porque o PEMAT 2022 é um estudo restrito à avaliação de propostas para gasodutos de transporte (EPE, 2014).

Neste momento, iniciam-se as simulações para determinar se o gasoduto atende à demanda máxima de fornecimento contratada pelos clientes de serviço, também, são inseridos pontos de demanda, assim como há ampliação de demanda em pontos existentes (EPE, 2014).

A primeira simulação termo-fluido-hidraúlica é realizada com o intuito de identificar a necessidade de ampliação da infraestrutura, seja através de novos pontos de compressão, ou novos dutos (EPE, 2014).

Simulações são feitas a fim de se adequar a infraestrutura às necessidades das demandas máximas identificadas com a menor infraestrutura possível. Esta etapa busca o dimensionamento dos gasodutos de transporte, inclusive suas eventuais estações de compressão, a serem construídos ou ampliados (EPE, 2014). ${ }^{19}$

$\mathrm{O}$ atendimento de uma demanda identificada pode envolver diferentes soluções de infraestrutura através das simulações. Para cada opção apresentada nas simulações,

\footnotetext{
${ }^{18}$ A premissa adotada pela EPE, de que são necessárias demanda e oferta, é referenciada como "paradoxo do ovo e da galinha" (chicken and egg dilemma), sendo este o grande dilema do planejador ao promover medidas que desenvolvam um mercado com as características de rede. No entanto, embora este dilema esteja presente nas condições regionais de desenvolvimento da demanda e oferta e na criação de um mercado de gás, não apresenta a mesma gravidade no que concerne ao balanço nacional de oferta e demanda, já que a oferta interna pode ser aumentada através de importações.

${ }^{19}$ É necessário determinar as atuais capacidades dos gasodutos existentes. Neste estudo foi considerado que toda a capacidade de transporte dos gasodutos existentes estava contratada no horizonte dos estudos.(PEMAT 2022, 2014).
} 
foram estimados os investimentos com base nos custos médios de construção, método metro.pol e se avaliou a viabilidade técnico-econômica simplificada, do empreendimento em função de um custo médio por metro.pol, e de uma Taxa Mínima de Atratividade (TMA). Esta etapa pode ser identificada na Figura 3.3 como EVTE simplificado (EPE, 2014).

$\mathrm{Na}$ etapa do EVTE simplificado (traçado no corredor), ilustrado Figura 3.3, obteve-se uma tarifa postal de transporte. A partir da definição dessa tarifa, avaliou-se o potencial de penetração do gás natural transportado nos dutos no mercado de destino, de acordo com os combustíveis disponíveis e substitutos (EPE, 2014).

A configuração de alternativa que apresentou maior viabilidade no EVTE simplificado segue para a próxima etapa: a análise ambiental (EPE, 2014).

Na etapa de simulação inicial (caracterização de duto de transporte - Figura 3.3) foram definidos traçados apoiados na menor distância possível, a configuração definida na etapa anterior deve ser contraposta com estudos cartográficos e de sensibilidade ambiental para o traçado preliminar. Após a análise ambiental, este traçado pode ter sofrido modificações significativas, portanto, há uma nova etapa de avaliação da viabilidade técnico-econômica (EPE, 2014).

A alternativa aprovada nas etapas anteriores é submetida a uma nova avaliação de viabilidade técnico-econômica, a EVTE detalhada, que incorpora outras análises econômicas além da TMA. Assim como na EVTE simplificada é obtida a tarifa postal de transporte, agora baseada no CAPEX e OPEX do investimento para uma TMA fixada (EPE, 2014).

Finalmente, as alternativas de gasodutos que foram consideradas viáveis nas etapas anteriores, tem a sua elegibilidade consolidada através de uma avaliação onde as informações referentes aos projetos encontram-se em um nível suficiente de maturação (EPE, 2014).

A elegibilidade de um gasoduto de transporte pela EPE demonstra as alternativas que apresentam a fundamentação necessária para que o MME decida acerca da conveniência e oportunidade da proposição em análise no horizonte decenal, visando seu encaminhamento ao processo de Chamada Pública e, posteriormente, à Licitação (EPE, 2014).

Para o entendimento de cada uma das etapas da Figura 3.3, os itens 3.5, 3.6 e 3.7 descrevem a metodologia empregada pela EPE. 


\subsection{Projeções de oferta e demanda}

No PEMAT há a descrição da metodologia utilizada para a determinação das demandas (futuras e potenciais) e ofertas futuras. A metodologia escolhida para a caracterização da demanda é o Modelo Integrado de Planejamento Energético (MIPE) (EPE, 2014). A partir da descrição do MIPE percebe-se que este se aproxima à metodologia do Planejamento Integrado de Recursos (PIR), com uma abordagem Top Down.

\subsubsection{Projeção da demanda}

Utilizando dados do Balanço Energético Nacional (BEN) foram determinados os consumos energéticos dos setores da economia brasileiros, além do setor residencial. Para cada setor foi adotada uma premissa para a avaliação do potencial de penetração do gás natural como substituto a outras fontes energéticas. Para o setor residencial o gás natural seria substituto do GLP, e no setor de transporte foi avaliado o potencial de substituição de GNV em relação à gasolina (EPE, 2014).

Um dos pontos mais relevantes do MIPE é a verificação do potencial de penetração do gás natural comparativamente aos outros insumos energéticos. Por exemplo, no setor industrial, o método leva em consideração as barreiras tecnológicas e econômicas à substituição das fontes energéticas utilizadas e o gás natural.

No estudo a premissa adotada é que o gás natural seria o substituto de óleo combustível ou em alguns casos mais específicos como industrias de cerâmica ou vidro substituiria o GLP (EPE, 2014).

Para a projeção da demanda foram utilizados, inicialmente, os dados obtidos em pesquisa junto à Associação Brasileira das Empresas Distribuidoras de gás canalizado (ABEGAS) e consumidores industriais de gás natural (EPE, 2014).

A utilização destes dados ocorreu de forma parcimoniosa, já que se avaliou a compatibilização destas projeções com os modelos setoriais de economia e energia da própria EPE. Este alinhamento foi necessário para que o estudo desenvolvido estivesse de acordo com a visão energética da EPE. Desta forma, parcelas de mercado não compatíveis com esta restrição foram descartadas da projeção de demanda potencial (EPE, 2014). 
As projeções de demanda apoiaram-se em um cenário econômico resultante das revisões de perspectivas de expansão de atividades nos diversos setores de consumo, e na maneira que esta energia deve ser utilizada, apoiadas, principalmente, na expectativa de evolução do PIB no período e parâmetros macroeconômicos (EPE, 2014).

Na Tabela 3.1 são apresentadas as projeções de demanda não termelétrica por setor econômico e por região geográfica (mil m³/dia).

$\mathrm{Na}$ Figura 3.4, são apresentados os percentuais dos consumos atuais e dos consumos potenciais por classe de consumo (projeção EPE). Nota-se que a expectativa é que, embora haja um crescimento na demanda não termelétrica de gás natural, proporcionalmente, haverá uma perda de mercado para os outros setores (EPE, 2014). Esta visão é decisiva para os resultados do PEMAT 2022, como será abordado adiante.

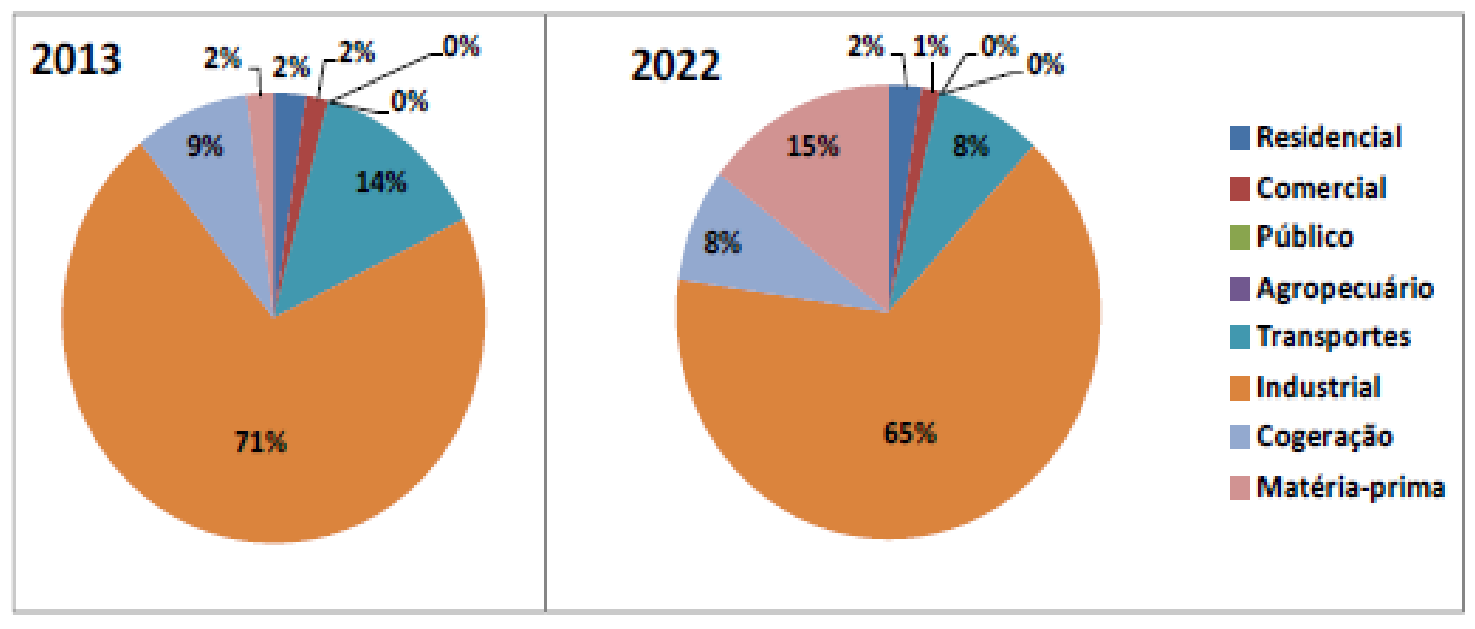

Figura 3.4 - Participação no consumo potencial de gás natural por classe Fonte: PEMAT 2022 (EPE, 2014) 
Tabela 3.1 - Demanda potencial não termelétrica de gás natural por região geográfica e classe de consumo ( $\left.\mathrm{mil} \mathrm{m}^{3} / \mathrm{dia}\right)$

\begin{tabular}{|c|c|c|c|c|}
\hline Região & Setor & 2013 & 2017 & 2022 \\
\hline \multirow{7}{*}{ Sudeste } & Residencial & 958 & 1.331 & 1.861 \\
\hline & Transportes & 3.761 & 3.952 & 4.312 \\
\hline & Industrial & 20.835 & 26.063 & 31.879 \\
\hline & Cogeração & 1.357 & 1.461 & 1.551 \\
\hline & Matéria-prima & 40 & 4.671 & 4.671 \\
\hline & Outros* & 553 & 722 & 887 \\
\hline & Total & 27504 & 38200 & 45161 \\
\hline \multirow{7}{*}{ Sul } & Residencial & 28 & 72 & 148 \\
\hline & Transportes & 716 & 863 & 1.075 \\
\hline & Industrial & 3.094 & 6.077 & 7.721 \\
\hline & Cogeração & 522 & 1.531 & 2.819 \\
\hline & Matéria-prima & 173 & 3.532 & 3.596 \\
\hline & Outros* & 70 & 116 & 192 \\
\hline & Total & 4.603 & 12.191 & 15.551 \\
\hline \multirow{7}{*}{ Nordeste } & Residencial & 28 & 80 & 131 \\
\hline & Transportes & 1.030 & 1.201 & 1.487 \\
\hline & Industrial & 4.703 & 8.575 & 11.514 \\
\hline & Cogeração & 1.682 & 2.193 & 2.856 \\
\hline & Matéria-prima & 628 & 1.660 & 2.520 \\
\hline & Outros* & 53 & 107 & 198 \\
\hline & Total & 8.124 & 13.816 & 18.706 \\
\hline \multirow{7}{*}{ Centro -Oeste } & Residencial & 1 & 16 & 91 \\
\hline & Transportes & 36 & 94 & 291 \\
\hline & Industrial & 371 & 575 & 1.152 \\
\hline & Cogeração & 6 & 9 & 13 \\
\hline & Matéria-prima & 0 & 2.300 & 2.300 \\
\hline & Outros* & 6 & 10 & 42 \\
\hline & Total & 420 & 3.004 & 3.889 \\
\hline \multirow{7}{*}{ Norte } & Residencial & & & \\
\hline & Transportes & & & \\
\hline & Industrial & & 5.200 & 6.400 \\
\hline & Cogeração & & & \\
\hline & Matéria-prima & & & \\
\hline & Outros* & & & \\
\hline & Total & & 5.200 & 6.400 \\
\hline \multicolumn{2}{|c|}{ Total } & 40.651 & 72.411 & 89.707 \\
\hline
\end{tabular}

Fonte: PEMAT 2022 (EPE, 2014) 
Para a projeção da demanda termoelétrica, a EPE considerou a metodologia descrita na Figura 3.5.

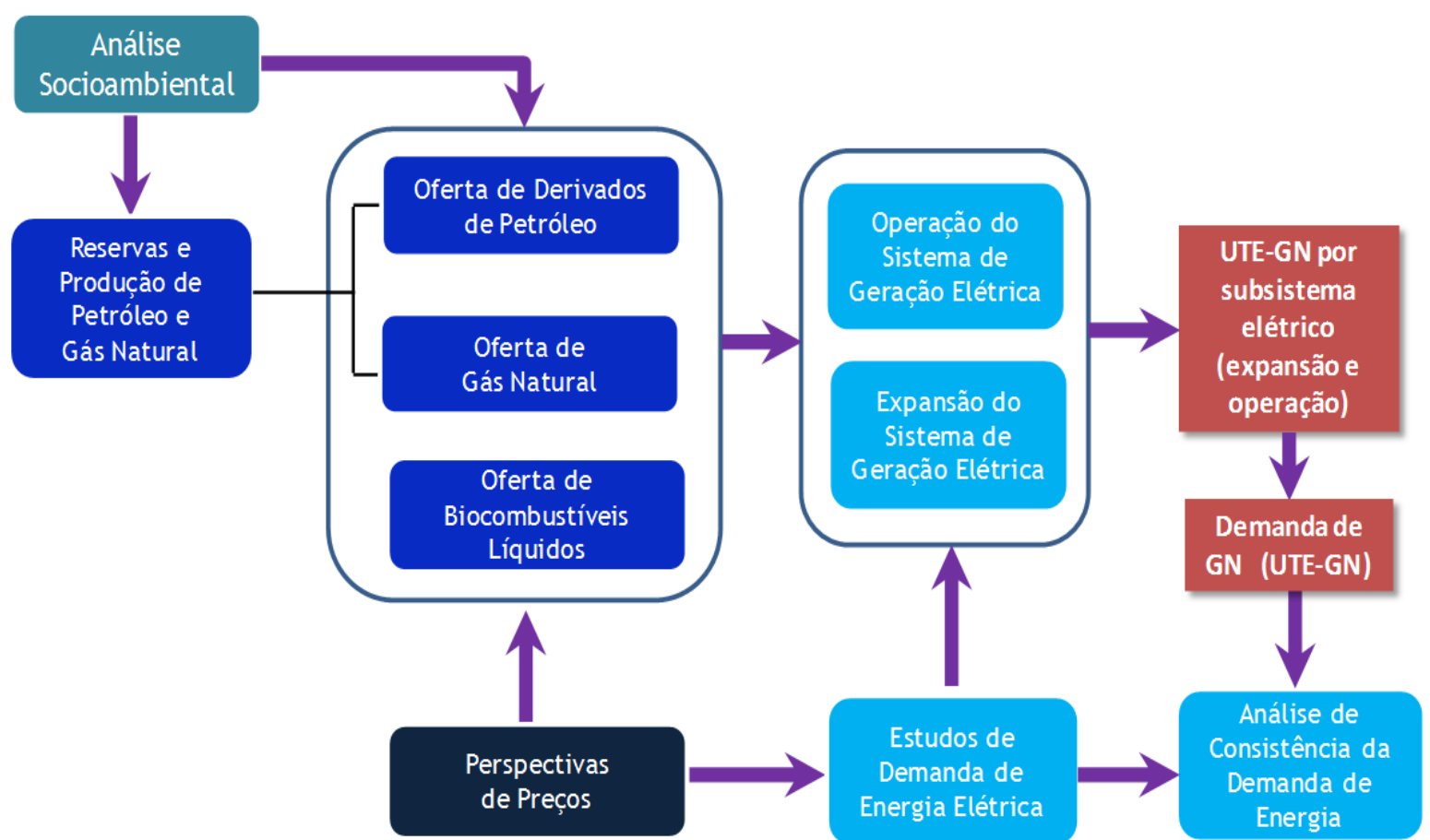

Figura 3.5 - Representação esquemática do processo de estimativa de demanda de gás natural para a geração de eletricidade

Fonte: PEMAT 2022 (EPE, 2013)

No PEMAT 2022, foram consideradas demandas de usinas termoelétricas a gás natural ${ }^{20}$ em operação, ou vencedoras em leilão de energia nova, além das termoelétricas indicativas que haviam sido consideradas no PDE 2022.

Contudo, estas últimas não foram consideradas para a simulação termo-fluidohidráulica porque a localização destas demandas concentradas impacta o resultado. Assim só foram consideradas na simulação as termoelétricas que impactam os projetos de gasodutos analisados (EPE, 2014).

Finalmente, para a consolidação das projeções de demanda localizada, os projetos foram agregados por municípios.

O fluxograma apresentado na Figura 3.6 é a representação desta análise e das escolhas da EPE, com o intuito de adequar e verificar as informações obtidas junto às distribuidoras.

\footnotetext{
${ }^{20}$ Para fins de avaliação, foram considerados cenários de despacho máximo para as usinas termelétricas, nos quais todas as usinas são atendidas exclusivamente com gás natural (mesmo aquelas do tipo bicombustível, que poderiam vir a ser supridas com combustíveis substitutos).
} 


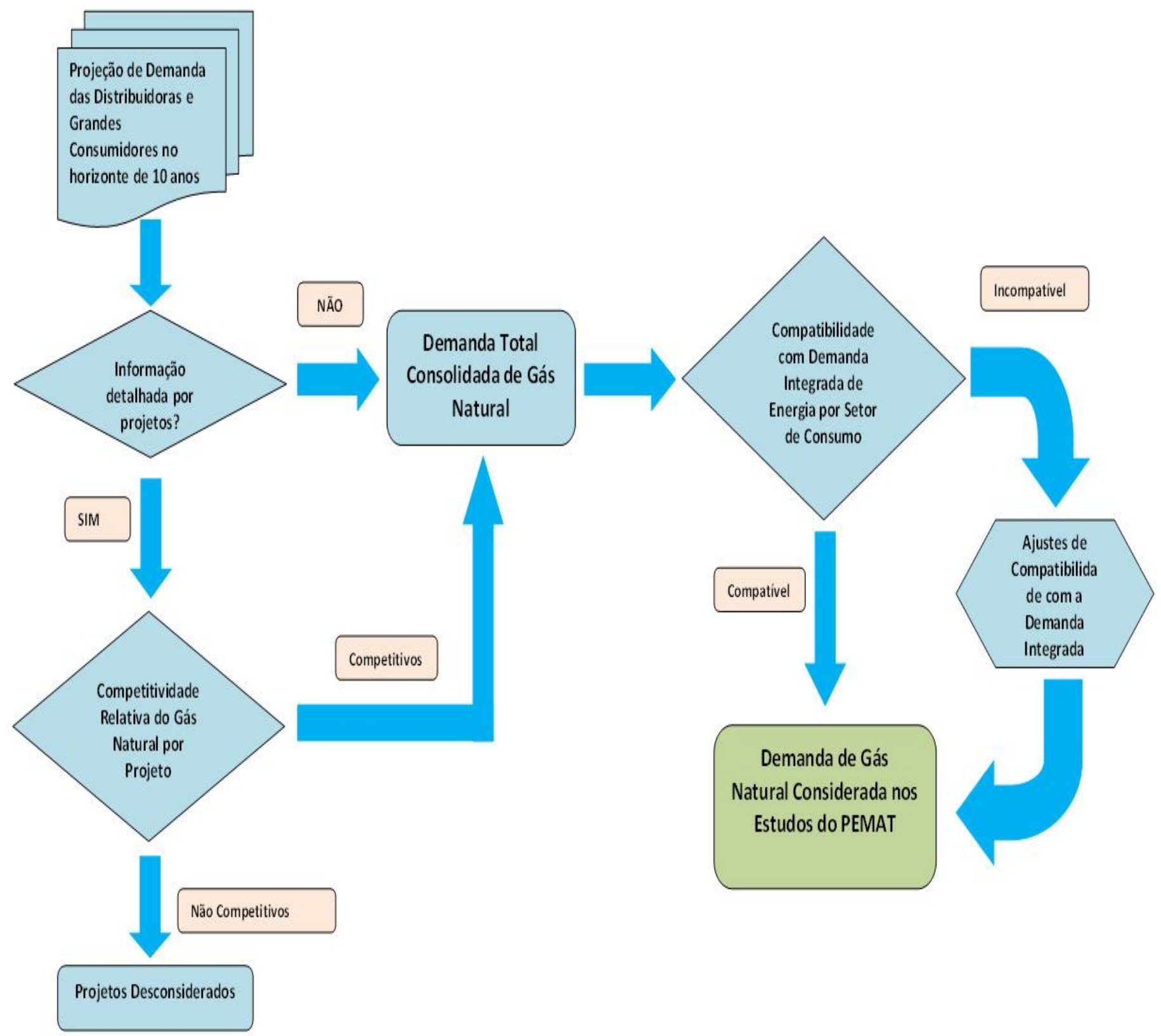

Figura 3.6 - Tratamento das informações coletadas

Fonte: PEMAT 2022 (EPE, 2013)

Com estas informações, a EPE elaborou mapas por unidade da Federação com as indicações de municípios e com demandas potencias para justificar uma posterior análise da viabilidade de projetos de novos gasodutos de transporte.

Na Tabela 3.2 são apresentadas as projeções de demanda termoelétrica e não termoelétrica potenciais para o período do estudo (EPE, 2014). 
Tabela 3.2 - Demanda potencial de gás natural no sistema integrado (milhões $\mathrm{m}^{3} /$ dia)

\begin{tabular}{lccc} 
& $\mathbf{2 0 1 3}$ & $\mathbf{2 0 1 7}$ & $\mathbf{2 0 2 2}$ \\
\hline \hline Demanda Não Termelétrica & 60,8 & 98,2 & 127,9 \\
Demanda Termelétrica Potencial & 41,3 & 46 & 52,5 \\
\hline Demanda Total & 102,1 & 144,2 & 180,4 \\
\hline
\end{tabular}

Fonte: PEMAT 2022 (EPE, 2014)

Na Figura 3.7 apresenta-se a composição final da demanda de gás natural (projeção EPE), no sistema integrado em 2022 (EPE, 2014).

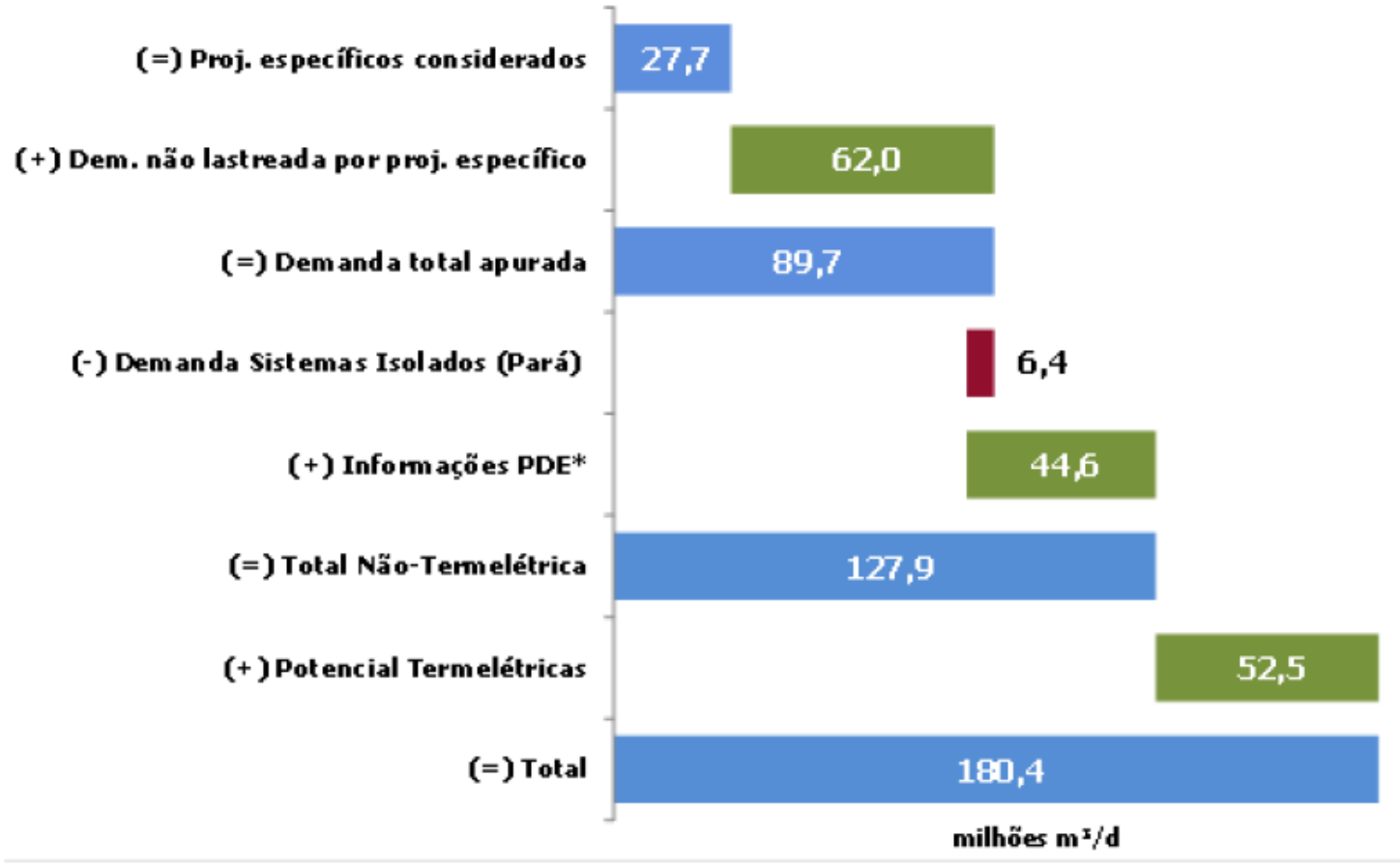

Figura 3.7 - Demanda de gás natural no sistema interligado em 2022

Fonte: PEMAT 2022, (EPE, 2014)

A escolha da EPE em empregar as premissas de estratificação e agregação de valores foram decisivas para o resultado do PEMAT 2022 (EPE, 2014).

A presente dissertação de mestrado defende que quando se utiliza o planejamento de mínimo custo, deve-se estratificar as informações de forma a contemplar a eficiência energética, e, neste ponto, compreender que a substituição de tecnologias e fontes para 
determinados usos finais deve ser avaliada não apenas por uma análise com ferramentas de mérito econômicas, mas principalmente porque promove maiores benefícios sociais.

Igualmente, essa pesquisa de mestrado entende que a principal meta de um estudo governamental, que visa promover a inserção de um recurso em sua matriz energética, deve ser, procurar, através da substituição de fontes, aumentar a eficiência global do sistema.

\subsubsection{Projeção da oferta}

A metodologia utilizada para a projeção da oferta no PEMAT 2022 não diferenciase significativamente da empregada nos estudos dos Planos Decenais de Energia (PDEs) realizados pela EPE, em seus aspectos gerais é a mesma, a distinção restringe-se à regionalização, já que o foco regional não é apresentado nos PDEs e é determinante no PEMAT (EPE, 2014).

Para obter a oferta potencial de gás natural, a EPE utilizou o seguinte critério: a oferta potencial disponível é a soma das importações e da produção líquida disponível (gás natural seco), sendo que esta última parcela corresponde à produção líquida de gás natural úmido menos a absorção nas UPGNs (observar na Figura 3.8) (EPE, 2014).

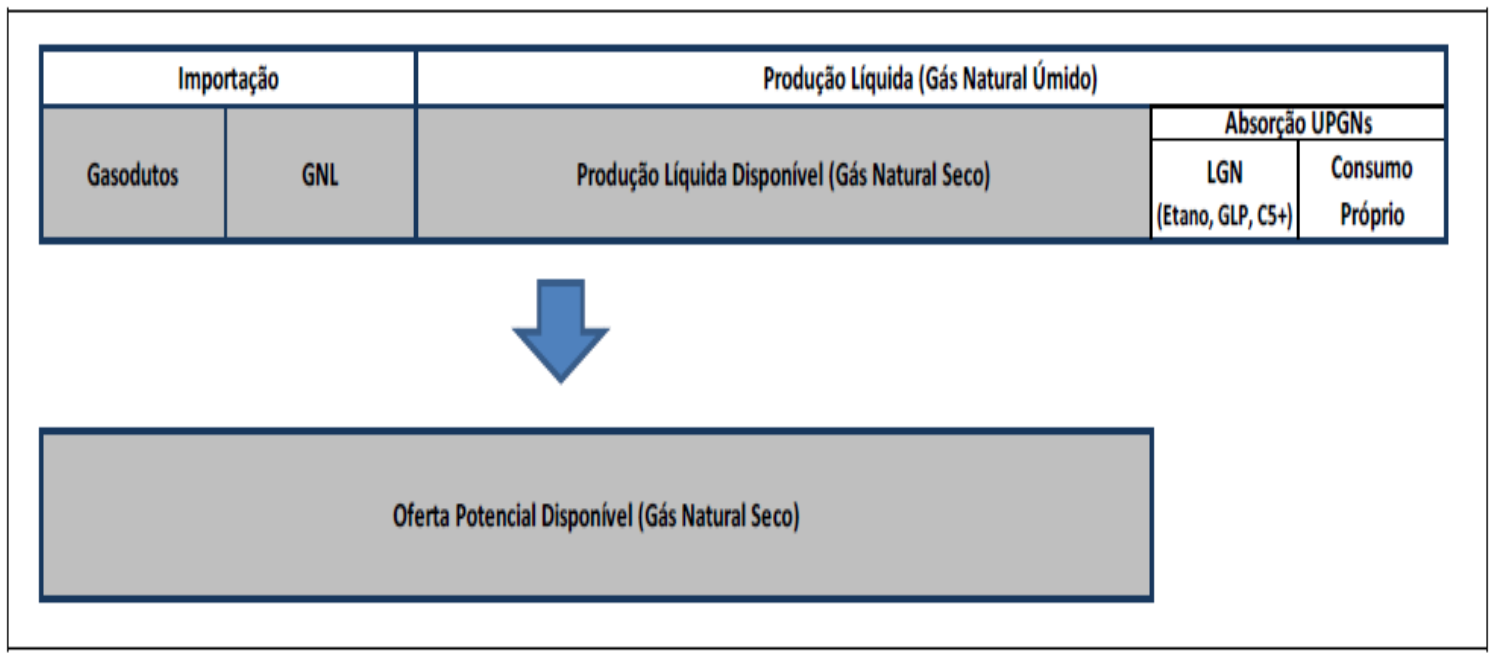

Figura 3.8 - Esquema da definição da oferta potencial disponível de gás natural (seco)

Fonte: PEMAT 2022 (EPE, 2013). 
A projeção da oferta de gás natural úmido é estimada a partir da produção bruta de gás natural úmido, descontando-se a queima, a reinjeção e o consumo, sendo que parte significativa da produção é de gás associado ao petróleo. A projeção de petróleo é uma das bases desta estimativa (EPE, 2014). A Figura 3.9 é uma representação deste cálculo.

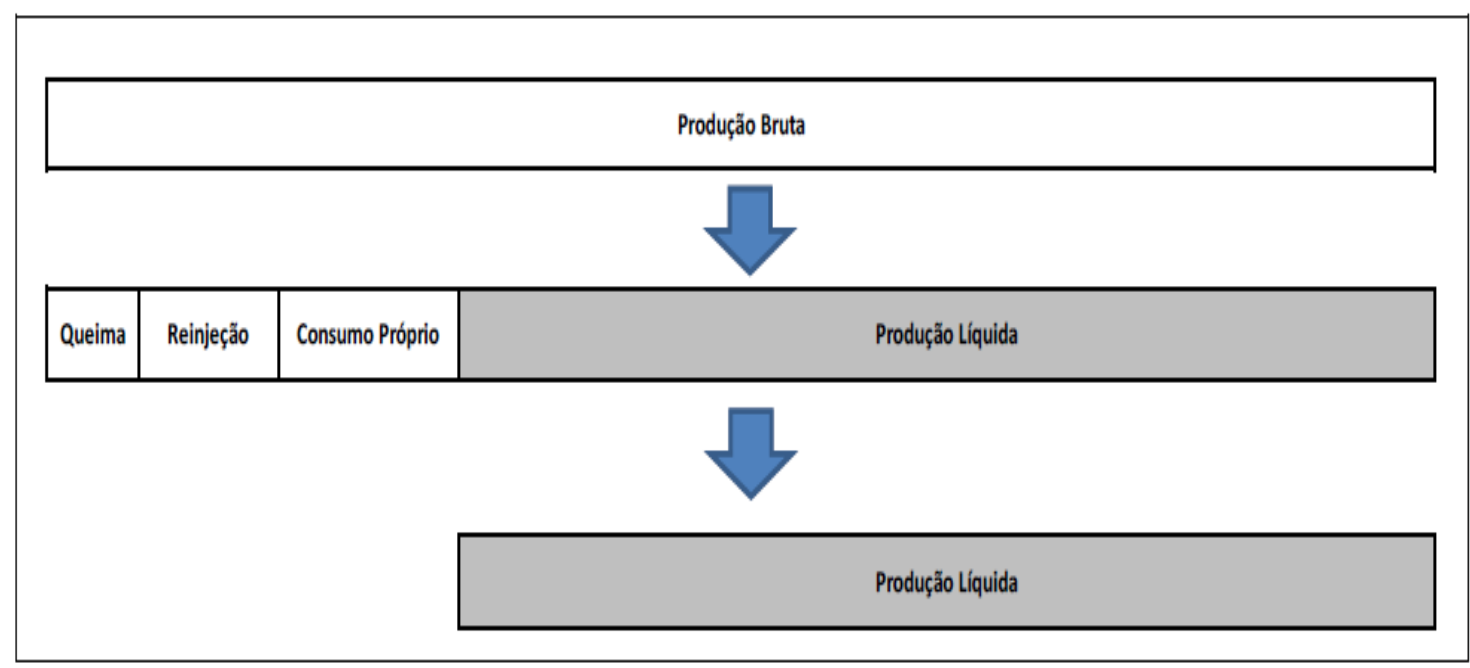

Figura 3.9 - Esquema da definição da produção líquida de gás natural (úmido)

Figura 3.9 - Esquema da definição da produção líquida de gás natural (úmido)

Fonte: PEMAT 2022 (EPE, 2014)

Como dito, a principal diferença das projeções de oferta realizadas no PEMAT 2022 para as apresentadas no PDE 2022 é a regionalização. Nos resultados do PEMAT são apresentados valores das Unidades Produtivas (UP). Estas unidades correspondem às jazidas, ou em produção, ou em desenvolvimento, ou em avaliação, isto em caso de recursos descobertos $(\mathrm{RD})^{21,22}$. Já no caso de recursos não descobertos (RND), estas unidades correspondem a prospectos ainda não perfurados (EPE, 2014).

\footnotetext{
${ }^{21}$ Para as unidades produtivas com reserva declarada a EPE utilizou dados da página eletrônica da ANP disponíveis na página eletrônica do banco de dados de exploração e produção (BDEP). Para as unidades produtivas contingentes e recursos não descobertos a EPE utilizou, além dos dados da ANP dos blocos exploratórios do BDEP, mapas e informações do Estudo Zoneamento das Áreas de Interesse de Petróleo e Gás Natural (EPE, 2012a), do Projeto APEP (EPE, 2008) e as Notas Técnicas relativas às rodadas 6 a 11 de licitações disponibilizadas pelo MME.

22 Para as previsões de produção dos recursos descobertos com comercialidade comprovada, foram utilizadas as reservas totais (RT: soma das provadas, prováveis e possíveis) de cada campo de petróleo ou gás no País, conforme registros da ANP referentes a 31 de dezembro de 2011. Quanto aos dados volumétricos dos recursos descobertos na categoria contingente, foram consideradas, na sua maioria, informações contidas nos planos originais de avaliação de descobertas em blocos exploratórios. As estimativas dos recursos não descobertos (potencial petrolífero) nos blocos contratados até 30 de março de 2012 foram elaboradas considerando-se a diversidade de chances de descobertas comerciais nas bacias
} 
Para cada unidade produtora (UP) foram estimados os estoques, que dependem do tipo de recurso; recursos descobertos (RD) e recursos não descobertos (RND). Entre os recursos descobertos estão as reservas totais $(\mathrm{RT})$ e as reservas contingentes $(\mathrm{RC})$ e entre os recursos não descobertos estão os recursos das áreas sob concessão (RND-E) e das áreas da União não contratadas (RND-U) ${ }^{23}$ (EPE, 2014).

As curvas de produção foram baseadas nos modelos típicos, ou seja, com uma fase inicial, de crescimento; uma segunda fase, conhecida como patamar de estabilização de produção; e, a terceira fase, de declínio. Assim como os estoques, estas curvas foram definidas a partir do tipo do recurso. ${ }^{24}$ Com isto foi possível se obter valores para a produção bruta, que compreendem a soma das contribuições de produção de cada UPs, estando estas separadas por recursos. Os resultados destas estimativas foram apresentados estratificados na forma de gráficos e tabelas (EPE, 2014).

A Erro! Fonte de referência não encontrada. revela a previsão de produção bruta potencial nacional diária de gás natural até 2022, o período em que compreende o PEMAT 2022.

A maior proporção de produção, segundo as projeções da EPE, é de gás associado (EPE, 2014). Assim pode-se notar a coerência entre as previsões de produção de gás (ilustradas na Figura 3.10) e petróleo (Erro! Fonte de referência não encontrada..

brasileiras. Como são observados os níveis de confidencialidade dos dados fornecidos pelas diversas fontes, os resultados só são disponibilizados agregados em níveis permitidos.

\footnotetext{
${ }^{23}$ No caso das Reservas Totais (RT), utilizou-se dados do Boletim Anual de Reserva (BAR) da ANP; No caso dos Recursos Contingentes (RC), utilizou-se, quando os recursos possuíam, dados dos Planos de Avaliação de Descoberta (PADs) elaborados pelas concessionárias para a ANP. Para os recursos contingentes $(\mathrm{RC})$ que não possuíam PADs e para os recursos não descobertos das áreas sob concessão (RND-E) foram feitas estimativas através de regressões lineares com a área do Ring-fencede cada unidade. E no caso dos estoques dos Recursos Não Descobertos da área da União (RDNU) foram considerados como referência os volumes das UPs sob concessão com uma estimativa baseada na analogia a depender do status exploratório de cada bacia. Também foram estimados o período a partir do qual cada UP entra em produção, novamente cada tipo de recurso teve uma base de partida desta estimativa. Para UPs pertencentes aos RC utilizou-se o estudo do PDE 2022, onde foi elaborada uma estimativa com base no tempo decorrido entre a declaração de comercialidade e o início da produção dos campos.

${ }^{24}$ No caso dos recursos descobertos na categoria de reservas, foram utilizados para os primeiros anos das projeções os Planos Anuais de Produção (PAP), submetidos pelas concessionárias à ANP compreendendo o período 2012-2016. Foi desenvolvido um modelo para as projeções de produção em áreas ainda não contratadas, a partir das unidades produtivas da União (UPU); neste modelo foi realizada uma simulação de produção onde foram agregados possíveis novos campos e uma otimização dos tempos para contratação, com isto estimou-se uma previsão de produção de petróleo e gás no longo prazo (cerca de 20 anos).
} 


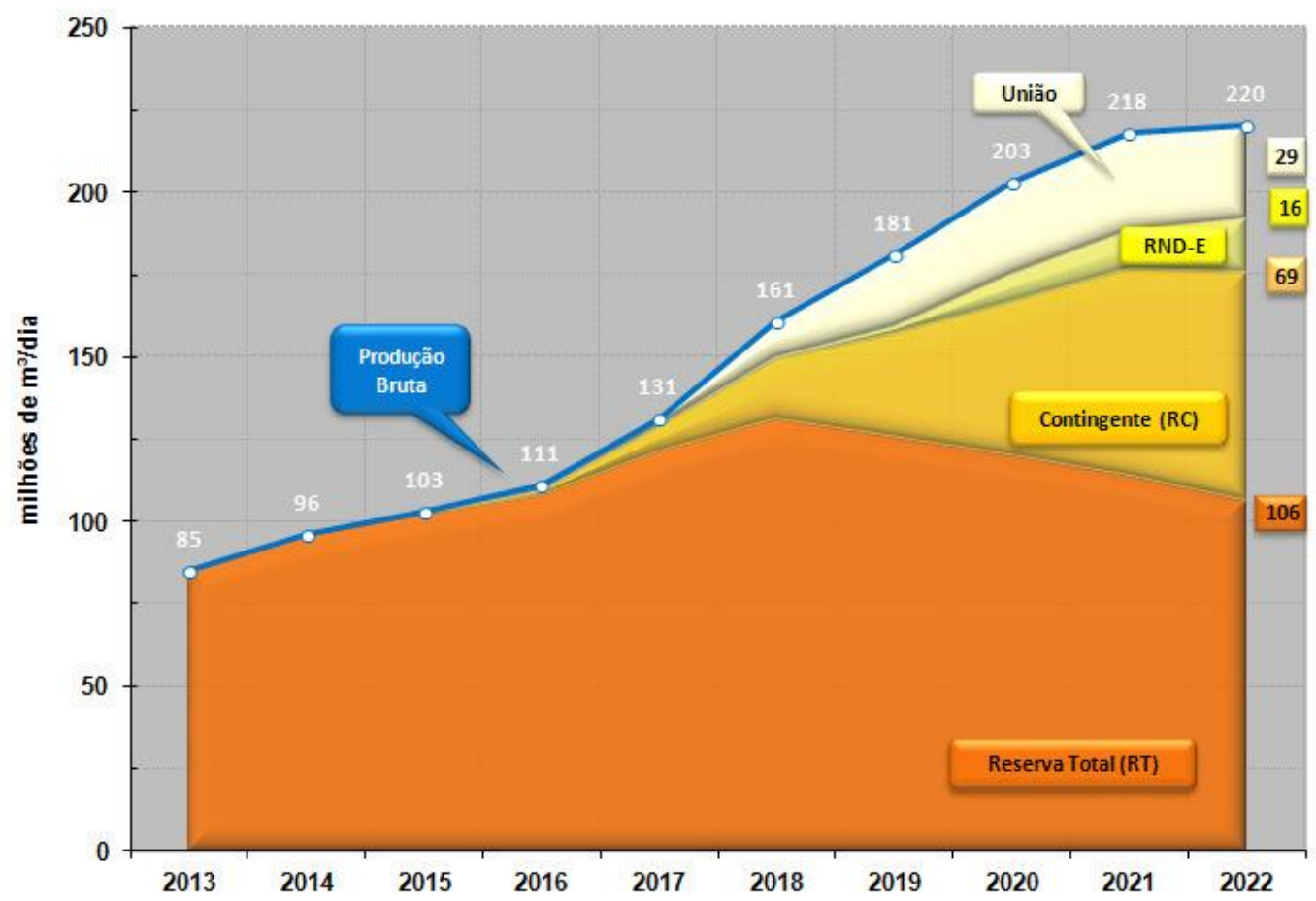

Figura 3.10 - Previsão de produção bruta potencial nacional de gás natural

Fonte: PEMAT 2022 (EPE, 2014)

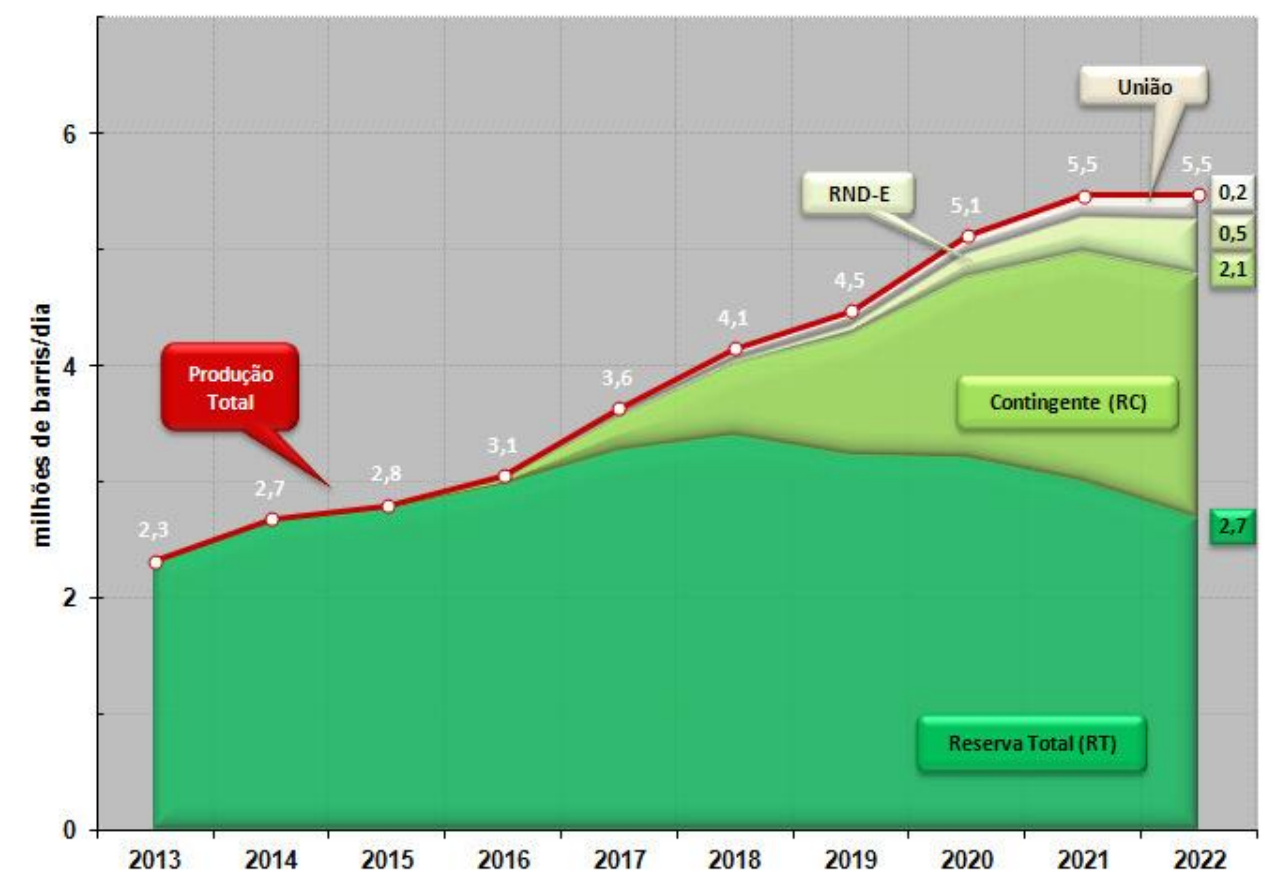

Figura 3.11 - Previsão de produção nacional de petróleo

Fonte: PEMAT 2022 (EPE, 2014) 
As reservas totais (RT) seguem uma tendência de crescimento até atingirem um pico de produção de 130,801 milhões de $\mathrm{m}^{3}$ diários, em 2018. O declínio desta produção é compensado inicialmente pela produção dos recursos contingentes (RC) e dos recursos não descobertos em áreas contratadas (RND-E) e, posteriormente, pelos recursos na área da União (RDNU). O aumento de produção dos recursos contingentes (RC) foi sustentado principalmente pelas acumulações do Pré- Sal Geológico (PSG) (EPE, 2014).

Conforme já ilustrado, a produção líquida potencial de gás natural é resultante da subtração dos seguintes fatores: queima, consumo e reinjeção da produção bruta. A estimativa desses fatores foi baseada no histórico da movimentação de gás natural ${ }^{25}$ (EPE, 2014). A Figura 3.12 é a ilustração do resultado desta estimativa.

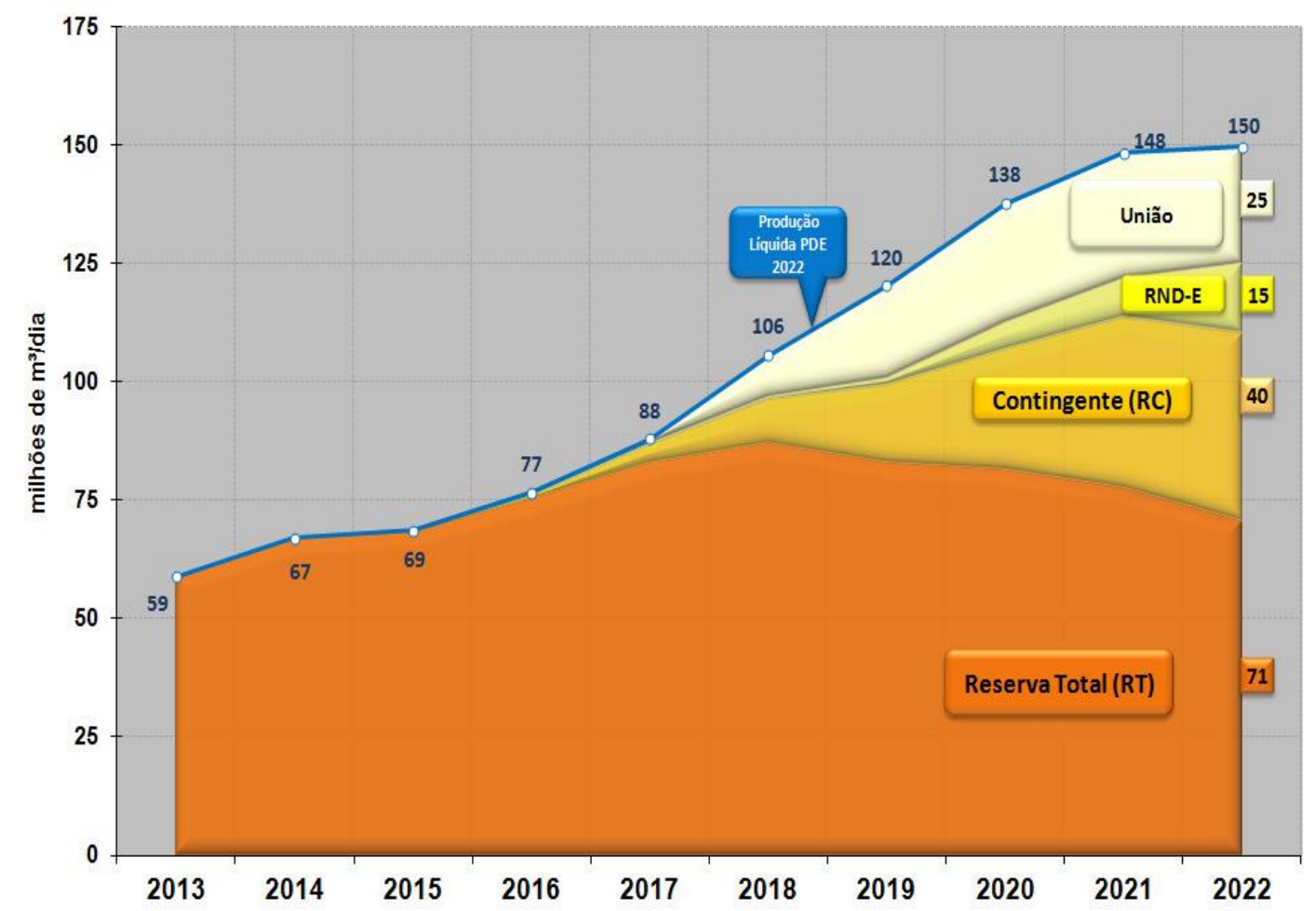

Figura 3.12 - Previsão de produção líquida potencial nacional de gás natural Fonte: PEMAT 2022 (EPE, 2014)

\footnotetext{
${ }^{25}$ Boletim Mensal de Produção - BMP da ANP, dados de 2012.
} 
$\mathrm{Na}$ descrição da metodologia, a EPE considerou importante salientar que as premissas utilizadas foram baseadas nas tendências de consumo próprio, prevendo a entrada de equipamentos, assim como a execução de políticas públicas visando à redução de emissões. Nesse sentido, destaca-se a redução do flaring em Unidades de Produção offshore, a substituição de energético e a viabilização de escoamento em determinadas áreas (EPE, 2014).

Como apresentado anteriormente, depois de obtida a produção líquida, ainda, deve-se considerar o processamento desta produção para a obtenção da produção de gás natural seco, além da adição da parcela de importação, a fim de se determinar as projeções de oferta de gás natural.

A Figura 3.13 é um esquema simplificado do processo de obtenção do gás natural seco a partir do gás natural úmido. Neste processo, além do gás natural seco obtém-se outros produtos como etano, GLP e gasolina natural $\left(\mathrm{C}_{5+}\right)$. Cada UPGN apresenta um rendimento e, embora a produção dos produtos varie conforme a composição do gás natural, este rendimento não apresenta grande variação. Apenas o gás natural produzido no país é tratado em UPGNs, o gás natural importado é processado na origem (EPE, 2014).

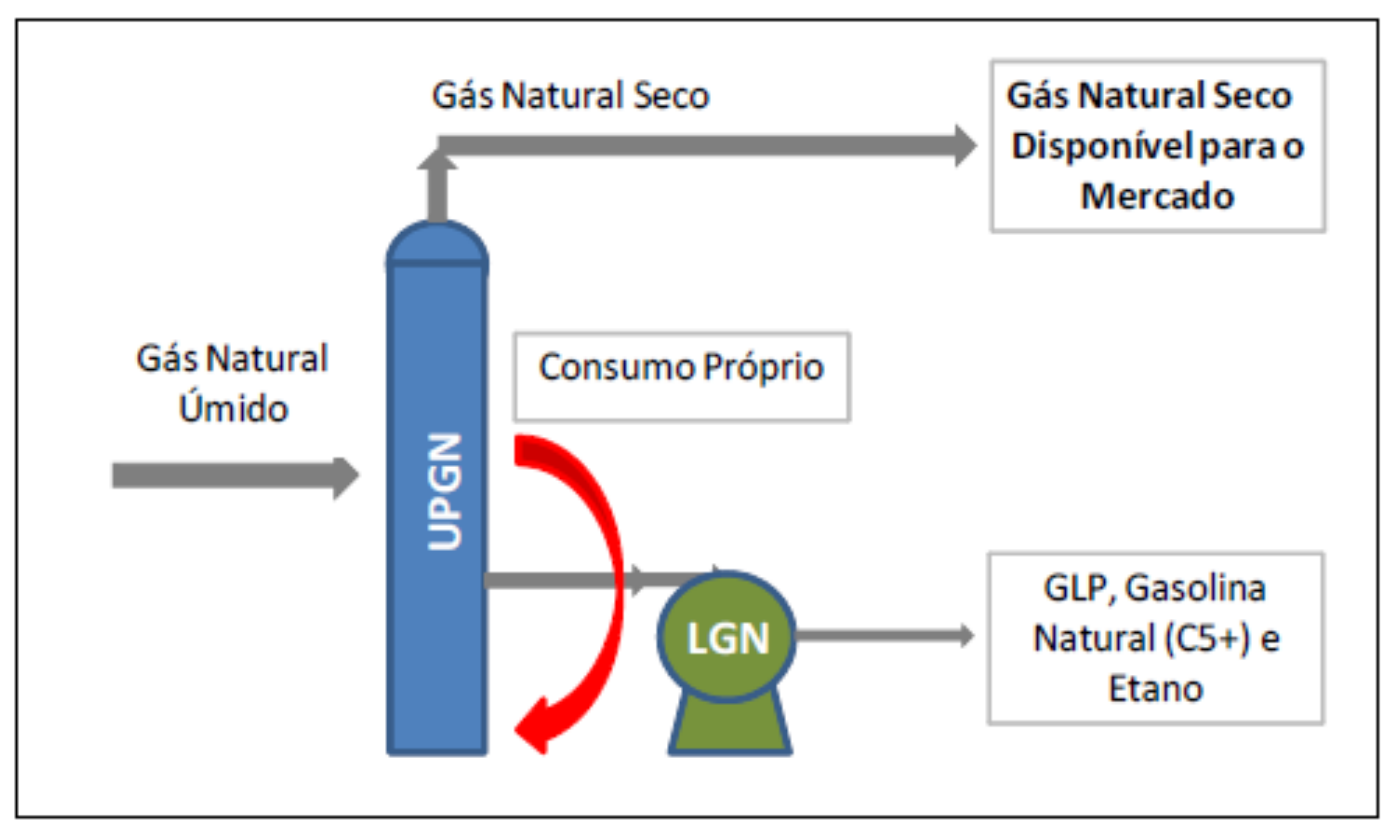

Figura 3.13 - Esquema simplificado da absorção em UPGNs

Fonte: PEMAT 2022 (EPE, 2014) 
Na Tabela 3.3, são apresentados dados, como capacidade e rendimento das UPGNs brasileiras. A capacidade do conjunto de UPGNs brasileiro é um fator limitante da oferta de gás natural seco nacional pelo menos durante os próximos cinco anos (EPE, 2014).

Mesmo com a entrada de outras unidades, a capacidade de processamento atual é de $97,0 \mathrm{MM} \mathrm{m}^{3} / \mathrm{d}$ e a capacidade das expansões anunciadas chegam a 44,0 $\mathrm{MM} \mathrm{m} 3 / \mathrm{d}$. Estas expansões envolvem tanto ampliações das UPGNs de Cabiúnas (adição de 13 MMm3/d) e UTGCA (adição de $10 \mathrm{MMm3/d),} \mathrm{quanto} \mathrm{a} \mathrm{construção} \mathrm{de} \mathrm{uma} \mathrm{nova} \mathrm{UPGN}$ no sítio do COMPERJ (21 MMm3/d $)^{26}$. (EPE, 2014)

A EPE considera que novos projetos, ainda não anunciados, ampliarão este parque e que depois de cinco anos a capacidade das UPGNs não é mais considerado fator limitante na determinação da oferta potencial de gás natural.

Uma vez estimada a projeção de produção nacional de gás natural seco, deve-se estimar as projeções de importação com vistas a se obter as projeções de oferta, que correspondem à soma destas duas parcelas. Então, o próximo passo da metodologia da EPE consistiu em estimar projeções das importações de gás natural para o período que compreende o PEMAT, definindo assim as projeções de oferta potencial para 2017 e 2022. A Figura 3.14 corresponde à ilustração dos pontos de importação de gás natural no território brasileiro.

Como pode-se observar, existem gasodutos de importação e terminais de regaseificação de GNL. Na Figura 3.14 também são apresentadas as capacidades diárias de importação de cada via. Em suas projeções, a EPE não considerou aumento significativo da capacidade de importação, seja por gasodutos ou via GNL (EPE, 2014).

Nos terminais da Bahia de Guanabara e do Pecém, o processo de regaseificação e o armazenamento do gás liquefeito, dá-se através de navios contratados por dez anos, da empresa Golar LNG (Noruega). Este gás destina-se sobretudo à demanda termelétrica ${ }^{27}$ (EPE, 2014).

\footnotetext{
${ }^{26}$ A UPGN que será construída no sítio do Comperj foi anunciada após determinação de que o escoamento da produção de gás natural pré-sal da bacia de Santos seria feita através do gasoduto de escoamento da produção - Rota 3.

${ }^{27} \mathrm{O}$ parque brasileiro de usinas termelétricas foi planejado para servir de sistema backup ao parque gerador hidrelétrico que constituí a base da matriz de geração elétrica brasileira, devido à intermitência desta fonte.
} 
Tabela 3.3 - UPGNs existentes e seus respectivos índices de rendimento

\begin{tabular}{|c|c|c|c|c|}
\hline UPGN & Município & $\begin{array}{l}\text { Capacidade } \\
\text { (MM m³/dia) }\end{array}$ & Sítio & $\begin{array}{l}\text { Índice } \\
\text { gás seco }\end{array}$ \\
\hline $\mathrm{RPBC}$ & Cubatão (SP) & 2,3 & $\mathrm{RPBC}$ & 0,975 \\
\hline $\mathrm{U} 2500$ & & 2,5 & \multirow{2}{*}{ REDUC } & \multirow{2}{*}{0,872} \\
\hline U2600 & Duque de Caxias (RJ) & 2,5 & & \\
\hline URGN Cabiúnas & \multirow{5}{*}{ Macaé (RJ) } & 2,58 & \multirow{5}{*}{ Cabiúnas } & \multirow{5}{*}{0,855} \\
\hline UPGN Cabiúnas & & 0,58 & & \\
\hline URL Cabiúnas I & & 4,5 & & \\
\hline URL Cabiúnas II & & 4,5 & & \\
\hline URL Cabiúnas III & & 4,86 & & \\
\hline UPGN Lagoa Parda & \multirow{2}{*}{ Linhares (ES) } & 0,45 & \multirow{2}{*}{ Lagoa Parda } & \multirow{2}{*}{0,998} \\
\hline DDP - Lagoa Parda & & 1,5 & & \\
\hline UPGN Cacimbas & \multirow{4}{*}{ Linhares (ES) } & 3,5 & \multirow{4}{*}{ DDP - Cacimbas } & \multirow{4}{*}{0,975} \\
\hline DPP Cacimbas & & 5,5 & & \\
\hline UPGN Cacimbas II & & 3,5 & & \\
\hline UPGN Cacimbas III & & 3,5 & & \\
\hline UAPO Sul Capixaba & Anchieta (ES) & 2,5 & $\begin{array}{c}\text { DPP SUL } \\
\text { CAPIXABA }\end{array}$ & 0,991 \\
\hline UAPO Caraguatatuba & \multirow{3}{*}{ Caraguatatuba (SP) } & 3 & \multirow{3}{*}{ UTGCA } & \multirow[t]{3}{*}{0,99} \\
\hline UAPO Caraguatatuba I & & 7,5 & & \\
\hline UAPO Caraguatatuba II & & 7,5 & & \\
\hline UPGN Candeias & Candeias (BA) & 2,9 & \multirow{3}{*}{ Bahia } & \multirow{3}{*}{0,936} \\
\hline UPGN Catu & \multirow{2}{*}{ Pojuca (BA) } & 1,9 & & \\
\hline URGN-3 BAHIA & & 2,5 & & \\
\hline UPGN Pilar & Pilar (AL) & 1,8 & Pilar & 0,956 \\
\hline UPGN Atalaia & Aracaju (SE) & 2,9 & Atalaia & 0,946 \\
\hline UPGN Carmópolis & Carmópolis (SE) & 0,35 & Carmópolis & 0,94 \\
\hline UPGN Guamaré I & \multirow{3}{*}{ Guamaré (RN) } & 2,3 & \multirow{3}{*}{ Guamaré } & \multirow{3}{*}{0,913} \\
\hline UPGN Guamaré II & & 2 & & \\
\hline UPGN Guamaré III & & 1,5 & & \\
\hline UPGN Lubnor & Fortaleza $(\mathrm{CE})$ & 0,35 & LUBNOR & 0,899 \\
\hline São Francisco & $\begin{array}{l}\text { São Francisco do Conde } \\
\text { (BA) }\end{array}$ & 6 & São Francisco & - \\
\hline UPGN Urucu I & \multirow{3}{*}{ Coari (AM) } & 0,71 & \multirow{3}{*}{ Urucu } & \multirow{3}{*}{0,932} \\
\hline UPGN Urucu II & & 6 & & \\
\hline UPGN Urucu III & & 3 & & \\
\hline
\end{tabular}

Fonte: PEMAT 2022, EPE 2014 


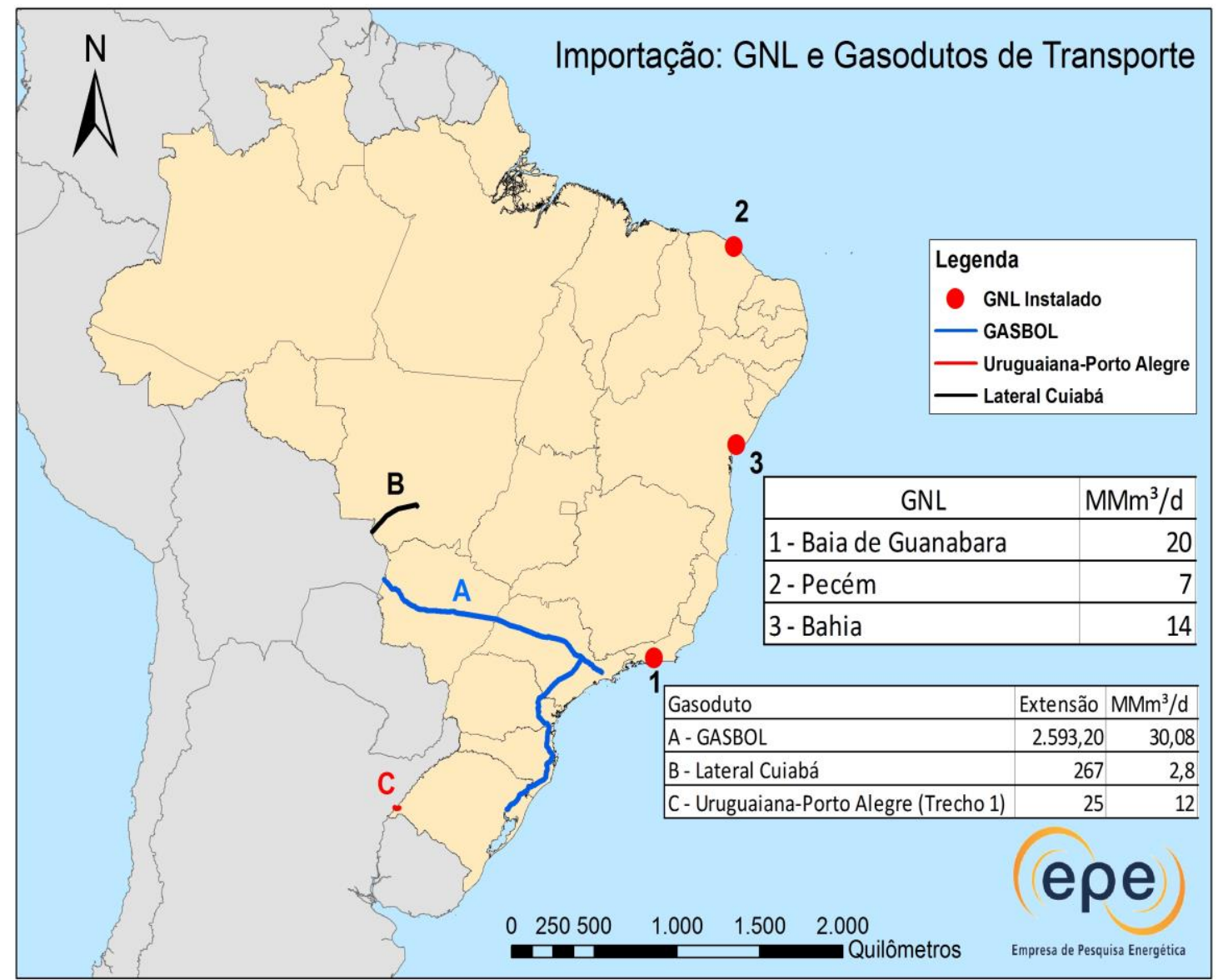

Figura 3.14 - Infraestrutura de importação de gás natural no Brasil

Fonte: PEMAT 2022, EPE 2013

As vantagens que este tipo de terminal apresenta é seu curto prazo de construção e instalação. Bem como à flexibilidade de comercialidade do gás. Nesses terminais, existe a possibilidade de se efetuar a compra do gás por contratos com modalidade diferentes, permitindo a variação do prazo do contrato de acordo com o interesse do comprador. $\mathrm{O}$ que é muito adequado para o atendimento da demanda termoelétrica brasileira, que pode adquirir o gás no mercado spot para eventual despacho.

A Tabela 3.4 - Capacidade de importação por gasoduto e por GNL no horizonte do estudo (Milhões de $\mathrm{m}^{3} /$ dia)apresenta os valores que a EPE adotou em suas projeções de oferta de gás natural no horizonte decenal. Na avaliação da EPE, todos os terminais e o GASBOL utilizarão suas capacidades máximas durante todo o período de planejamento. 
Tabela 3.4 - Capacidade de importação por gasoduto e por GNL no horizonte do estudo (Milhões de $\mathbf{m}^{3} /$ dia)

\begin{tabular}{ccccccccccc} 
Origem & $\mathbf{2 0 1 3}$ & $\mathbf{2 0 1 4}$ & $\mathbf{2 0 1 5}$ & $\mathbf{2 0 1 6}$ & $\mathbf{2 0 1 7}$ & $\mathbf{2 0 1 8}$ & $\mathbf{2 0 1 9}$ & $\mathbf{2 0 2 0}$ & $\mathbf{2 0 2 1}$ & $\mathbf{2 0 2 2}$ \\
\hline \hline GASBOL & 30,1 & 30,1 & 30,1 & 30,1 & 30,1 & 30,1 & 30,1 & 30,1 & 30,1 & 30,1 \\
\hline GNL-NE & 7 & 21 & 21 & 21 & 21 & 21 & 21 & 21 & 21 & 21 \\
\hline GNL-SE & 20 & 20 & 20 & 20 & 20 & 20 & 20 & 20 & 20 & 20 \\
\hline
\end{tabular}

Fonte: PEMAT 2022, EPE 2014.

Não foi considerada a entrada de novos pontos de importação, a não ser a entrada em operação do terminal da Bahia, com capacidade de $14 \mathrm{MM} \mathrm{m} 3 / \mathrm{d}$, que ocorreu em janeiro de $2014^{28}$ (EPE, 2014).

Assim, o PEMAT 2022 levantou todas as informações para determinar suas projeções de oferta potencial de gás natural no horizonte decenal (EPE, 2014).

\subsubsection{Balanço de demanda e oferta simulação termo-fluído-hidráulica}

O balanço de demanda e oferta, realizado no PEMAT 2022, necessita ser regionalizado e associado à rede existente e às alternativas de expansão de gasodutos (EPE, 2014). Na Figura 3.15 é apresentada a malha atual de gasodutos.

A malha de gasodutos conta, atualmente, com um total de $9.244 \mathrm{~km}$ distribuídos pelas regiões brasileiras. Grande parte desta malha encontra-se integrada $(8.583 \mathrm{~km})$. Porém, $661 \mathrm{~km}$ de gasodutos constituem sistemas isolados (Urucu-Coari-Manaus, Lateral Cuiabá e Uruguaiana-Porto Alegre Trecho 1) (EPE, 2014). Na Tabela 3.5 são apresentadas as transportadoras operadoras de cada trecho desta malha.

\footnotetext{
${ }^{28}$ O Boletim Mensal de Acompanhamento da Indústria de Gás Natural, do Ministério de Minas e Energia (2014).
} 


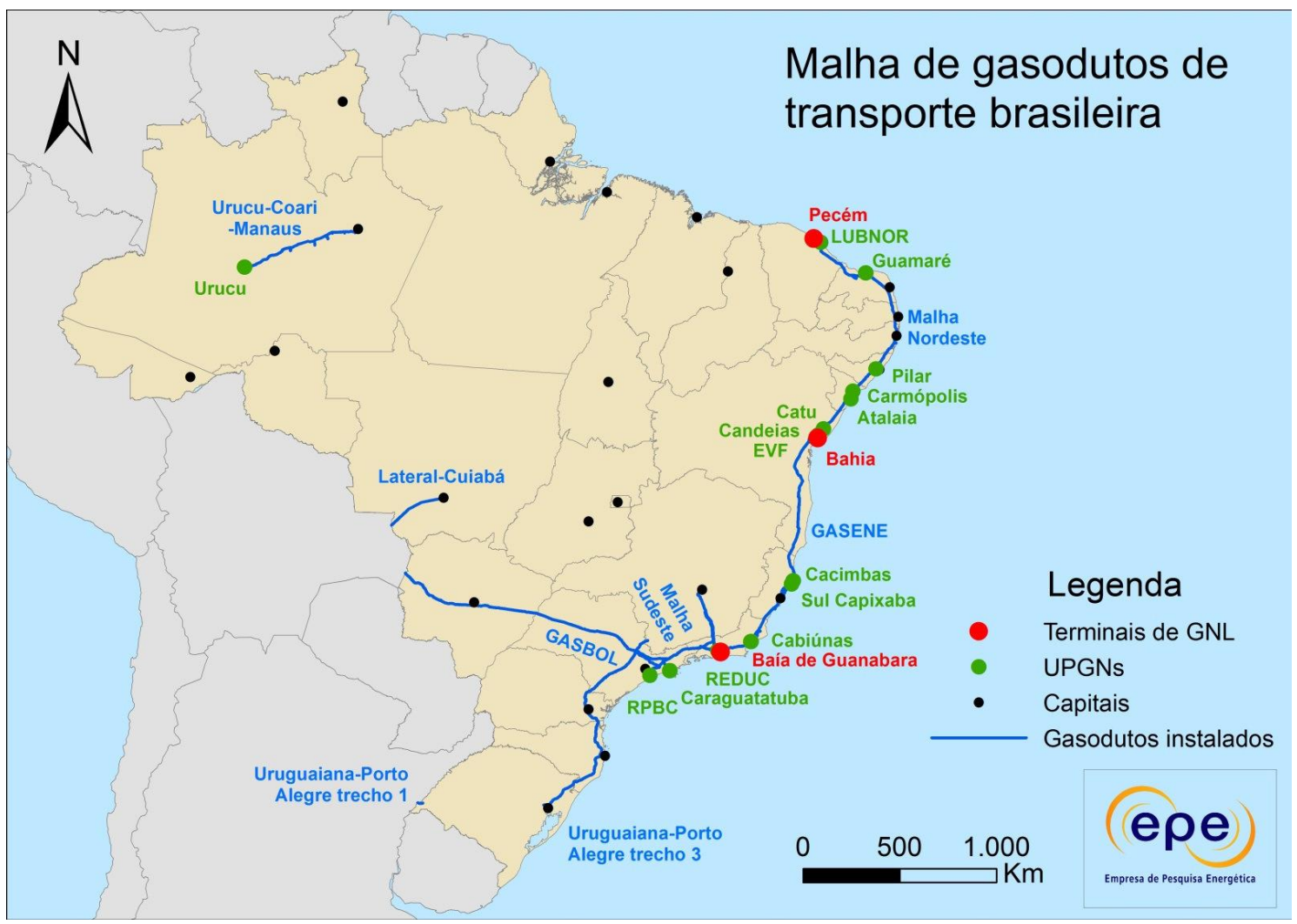

Figura 3.15 - Infraestrutura existente de gasodutos de transporte no Brasil em 2012

Fonte: PEMAT 2022 (EPE 2014).

Tabela 3.5 - Operação de gasodutos de transporte por transportadora no Brasil

\begin{tabular}{cccc} 
Transportadora & Gasoduto & Localidade & Extensão \\
\hline \hline Sulbrasileira de Gás (TSB) & $\begin{array}{c}\text { Uruguaiana/RS-Porto } \\
\text { Alegre/RS }\end{array}$ & $\begin{array}{c}\text { Argentina a Uruguaiana/RS } \\
\text { Porto Alegre/RS a Triunfo/RS }\end{array}$ & $50 \mathrm{~km}$ \\
\hline $\begin{array}{c}\text { Gas Ocidente do Mato Grosso } \\
\text { Ltda }\end{array}$ & $\begin{array}{c}\text { Gasoduto Lateral } \\
\text { Cuiabá }\end{array}$ & Bolívia-Mato Grosso $^{1}$ & $267 \mathrm{~km}$ \\
\hline $\begin{array}{c}\text { Brasileira Gasoduto Bolívia- } \\
\text { Brasil (TBG) }\end{array}$ & GASBOL & $\begin{array}{c}\text { Corumbá/MT a Paulínia/SP } \\
\text { Paulínia/SP a Guararema/SP }\end{array}$ & $2593 \mathrm{~km}$ \\
& Campinas/SP a Canoas/RS. & \\
\hline GASENE & ligação NE e SE & \\
Transpetro & Sistema Sudeste & malha integrada do sistema NE & 6.334 \\
& Sistema Nordeste & malha integrada do sistema SE & \\
& URUCU & Urucu-Coari-Manaus & \\
\hline
\end{tabular}

Notas: ${ }^{1} \mathrm{O}$ Gasoduto Lateral Cuiabá consiste no trecho do Gasoduto Bolívia-Mato Grosso no Brasil. A extensão total Gasoduto Bolívia- Mato Grosso é de 620 km.

Fonte: PEMAT 2022 (EPE 2014).

Para a determinação do balanço regionalizado, é utilizada a simulação termofluido-hidráulica. Esta simulação utiliza-se tanto da malha integrada quanto dos sistemas 
isolados ${ }^{29}$. A malha integrada nesta simulação é apresentada em subdivisões regionais (EPE, 2014). As Figura 3.16 e Figura 3.17 representam essas subdivisões.

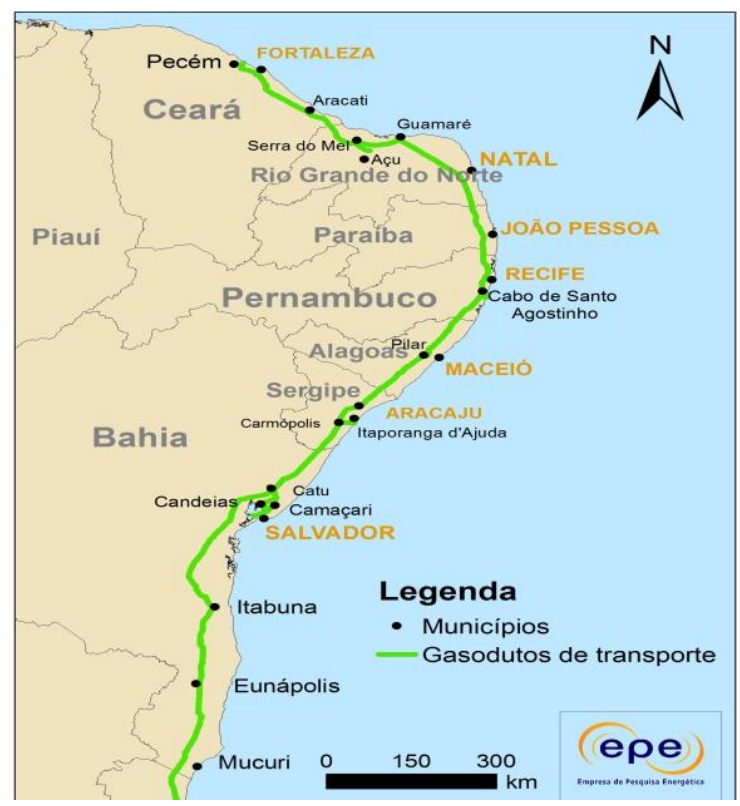

Figura 3.16 - Sistema de gasodutos de transporte da Região Nordeste

Fonte: PEMAT 2022 (EPE, 2014)

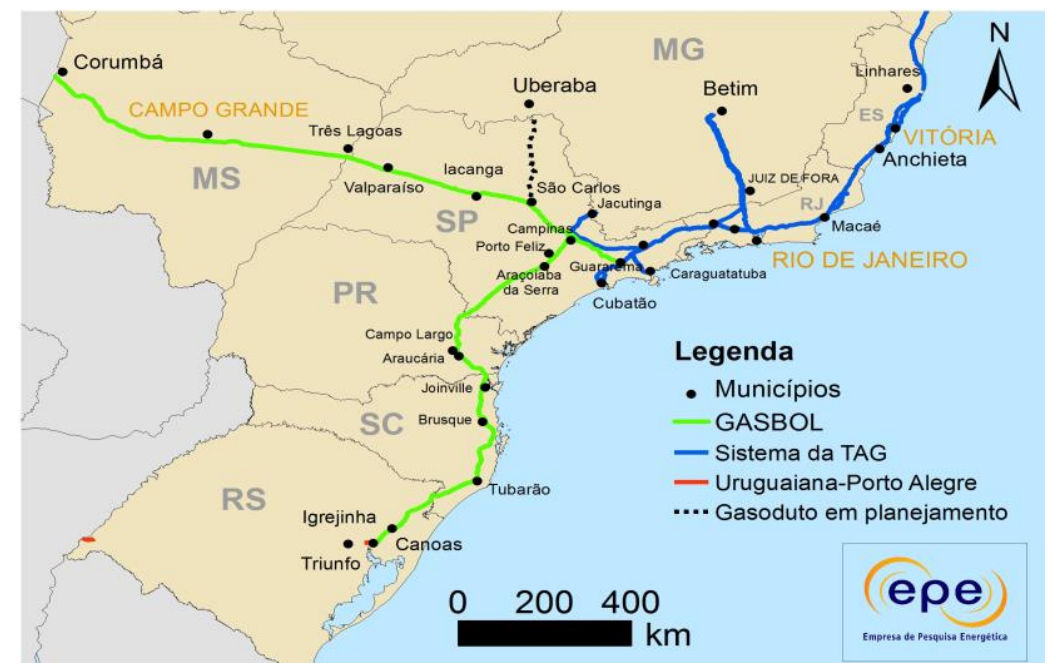

Figura 3.17 - Sistema de gasodutos de transporte da Região Sul/Sudeste/CentroOeste

Fonte: PEMAT 2022 (EPE 2014).

${ }^{29}$ Utilizou-se nas simulações tanto as malhas existentes quanto os projetos em análise, na infraestrutura existente, tanto a malha de gasodutos do sistema conectado quanto do sistema isolado, com exceções dos gasodutos Lateral Cuiabá e Uruguaiana-Porto Alegre Trecho 1 
A EPE utilizou, nas suas simulações, o programa Pipeline Studio, que se trata de um software desenvolvido pela Energy Solutions, no módulo TGNET (EPE, 2014). Como pode-se observar na Figura 3.18, para a simulação são definidos diversos parâmetros: os pontos de oferta e de entrega, compressores, dutos e válvulas.

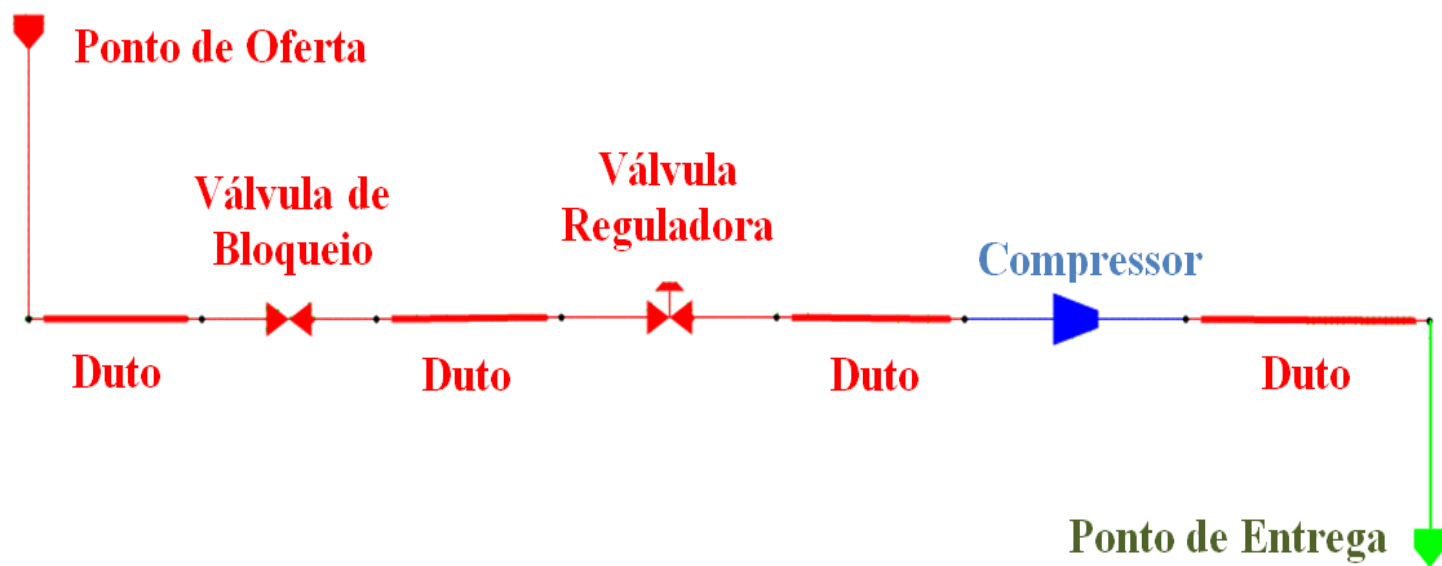

\section{Figura 3.18 - Representação do Pipeline Studio de um duto e seus principais constituintes}

Fonte: PEMAT 2022 (EPE 2014)

Os pontos de oferta correspondem aos pontos de entrada de gás na malha de dutos (UPGNs e pontos de entrada de gás importado, inclusive terminais de GNL). Já, os pontos de entrega correspondem aos pontos de escoamento do gás na malha de dutos para o atendimento das demandas (EPE, 2014).

Os compressores representam sistemas de compressão ${ }^{30}$. Os dutos devem ser definidos de acordo com suas características como rugosidade, coeficiente de atrito, etc (EPE, 2014).

E, finalmente, as válvulas podem ser de bloqueio, que permitem a limitação de volume escoado através da redução de seu percentual de abertura; ou válvulas reguladoras, que permitem regular, na entrada e/ou saída, o valor de pressão, volume ou de diferença de pressão (EPE, 2014).

O processo de simulação ocorre em duas etapas, que podem ser resumidas como:

\footnotetext{
${ }^{30}$ Os sistemas de compressão são ECOMPs (estações de compressão - próprio e definitivo) ou SCOMPs (serviços de compressão - alugado e temporário).
} 
- Etapa 1 - a atualização dos modelos utilizando dados e fontes diversas. Esta etapa consiste na alimentação do software com novos dados ${ }^{31}$ relativos a alterações ocorridas dentro do horizonte decenal nos parâmetros de entrada já citados anteriormente;

- Etapa 2 - simulação propriamente dita, da qual se obtêm os resultados. Nesta etapa, a partir das informações alimentadas na etapa 1, o software disponibiliza um diagnóstico da capacidade de transporte do gás a partir das características da malha e do balanço de oferta e demanda;

Como resultado da aplicação do software, a EPE pode avaliar as eventuais restrições de capacidade de transporte da malha de gasodutos (EPE, 2014).

A Tabela 3.6 apresenta o resultado do balanço de oferta e demanda das projeções realizada pela EPE para o PDE 2022. Os valores de "saldo" em vermelho equivalem a períodos onde a demanda será maior que a oferta.

Tabela 3.6 - Balanço de Demanda e Oferta potencias de gás natural no sistema integrado, conforme PDE 2022 (milhões de m³/dia)

\begin{tabular}{|c|c|c|c|c|c|c|c|c|c|c|}
\hline Descrição & 2013 & 2014 & 2015 & 2016 & 2017 & 2018 & 2019 & 2020 & 2021 & 2022 \\
\hline Demanda Potencial & 102,1 & 11,6 & 125,5 & 135,2 & 144,2 & 159,6 & 163,8 & 170 & 175 & 180,4 \\
\hline Demanda Não-Termelétrica & 60,8 & 68 & 81,9 & 91,6 & 98,2 & 113,6 & 116,9 & 121,4 & 124,5 & 127,9 \\
\hline Total Termelétricas & 41,3 & 43,6 & 43,6 & 43,6 & 46 & 46 & 46,9 & 48,6 & 50,5 & 52,5 \\
\hline Térmicas Gás & 32,7 & 34,9 & 34,9 & 34,9 & 34,9 & 34,9 & 35,8 & 37,5 & 39,4 & 41,4 \\
\hline Térmicas Bicombustível & 8,6 & 8,7 & 8,7 & 8,7 & 11,1 & 11,1 & 11,1 & 11,1 & 11,1 & 11,1 \\
\hline Oferta Potencial & 102,3 & 122 & 123,1 & 126,6 & 133,6 & 147,7 & 154,9 & 163,5 & 171,9 & 172 \\
\hline Recursos Descobertos & 45,2 & 50,7 & 51,9 & 55 & 59,1 & 63,1 & 59,5 & 57,1 & 53,3 & 46,6 \\
\hline $\begin{array}{l}\text { Recursos Contingentes } \\
\text { Recursos Não-Descobertos- }\end{array}$ & 0 & 0,2 & 0,1 & 0,3 & 2,8 & 7,5 & 13,7 & 21,5 & 31,2 & 35 \\
\hline $\begin{array}{l}\text { Empresas } \\
\text { Recursos Não-Descobertos- } \\
\text { União }\end{array}$ & & & 0 & 0,2 & 0,4 & 5,6 & 9,8 & 11,4 & 12,4 & 12,3 \\
\hline Importação GNL & 27 & 41 & 41 & 41 & 41 & 41 & 41 & 41 & 41 & 41 \\
\hline Importação gasoduto & 30,1 & 30,1 & 30,1 & 30,1 & 30,1 & 30,1 & 30,1 & 30,1 & 30,1 & 30,1 \\
\hline Saldo & $\mathbf{0 , 2}$ & 10,4 & 2,4 & 8,6 & 10,6 & 11,9 & 8,9 & 6,5 & 3,1 & 8,4 \\
\hline $\begin{array}{l}\text { Saldo sem as UTEs } \\
\text { Bicombustíveis }\end{array}$ & 8,8 & 19,1 & 6,3 & $\mathbf{0 , 1}$ & 0,5 & 0,8 & 2,2 & 4,6 & 8 & 2,7 \\
\hline
\end{tabular}

Fonte: PEMAT 2022 (EPE, 2014)

\footnotetext{
${ }^{31}$ As principais fontes de dados utilizadas: Planos de Negócios (Petrobrás); Boletim de Gás Natural Ministério de Minas e Energia (MME); Boletim de Gás Natural - Agência Nacional do Petróleo, Gás Natural e Biocombustíveis (ANP); E os principais dados são: terminais de regaseificação de GNL: expansão de capacidade e novos terminais; Gasodutos: implantação e ampliações de dutos e compressores; Parque de processamento: novas UPGNs, expansões de capacidade; Demanda downstream: novas unidades e expansão de consumo; Citygates: novos pontos de entrega e expansão de existentes.
} 


\subsection{Análise Socioambiental}

Considerando recomendações relevantes sob o aspecto socioambiental sobre os traçados preliminares e de seus corredores, o objetivo das análises socioambientais desenvolvidas no estudo da EPE é o de selecionar o traçado preliminar para as próximas etapas.

Esta avaliação é preliminar, para gasodutos elegíveis, serão necessárias avaliações mais precisas.

A fim de identificar a complexidade das áreas analisadas foram utilizadas ferramentas de SIG (Sistema de Informação Geográfica). Com estas ferramentas, consegue-se identificar áreas que devem ser evitadas, tanto sob o ponto de vista socioambiental, quanto econômico construtivo. Tais áreas condicionam a identificação das alternativas de localização dos traçados preliminares (EPE, 2014).

Para uma alternativa, é considerado um traçado inicial com uma largura de $20 \mathrm{~km}$, que poderá ser alterada em função do comprimento do gasoduto, entre outros aspectos.

Estudos posteriores definirão a melhor localização do traçado do gasoduto dentro deste corredor preferencial (EPE, 2014).

A partir do traçado preliminar são identificados elementos da paisagem a serem considerados na implantação do gasoduto ${ }^{32}$, podendo assim realizar uma composição de custos, comparáveis entre si, para cada alternativa. Para a caracterização socioambiental, foram consultadas e/ou utilizadas informações de diversas fontes ${ }^{33}$ (EPE, 2014). Para a avaliação das alternativas, os gasodutos foram classificados em dois grupos:

- Novos gasodutos, e

- Duplicação de gasodutos.

\footnotetext{
${ }^{32}$ Estes elementos dizem respeito a componentes presentes no percurso inicial, como travessias de recursos hídricos, rodovias, linhas de transmissão, áreas alagadas, imóveis rurais, assentamentos, feições cársticas, processos minerários, afloramentos rochosos, ocorrências minerais e aeródromos.

${ }^{33}$ As fontes de informações utilizadas foram: áreas dos processos minerários (DNPM, 2012); base cartográfica integrada do Brasil ao milionésimo digital (IBGE, 2009a); mapa das áreas prioritárias para a conservação, uso sustentável e repartição de benefícios da biodiversidade brasileira (MMA-Probio, 2007a); mapa de biomas do Brasil (IBGE, 2004); mapa de ocorrência de cavernas (ICMBio/Cecav, 2012); mapa de projetos de assentamento (INCRA, 2011); mapa de terras indígenas (FUNAI, 2012); mapa de unidades de conservação federais e estaduais (ICMBio, 2012; Eletrobrás,2011); mapeamento da cobertura vegetal dos biomas brasileiros (MMA-Probio/2007b); SRTM (Embrapa, Monitoramento por Satélite, 2005).
} 
Para a avaliação socioambiental de novos gasodutos, a definição do traçado inicial, deve-se evitar a interferência em unidades de conservação de proteção integral e terras indígenas. As Figura 3.19 e 3.20 são os mapas dessas regiões que serviram de base de dados para essa etapa dos estudos da EPE. Os traçados são definidos com o intuito de minimizar os impactos socioambientais da construção e operação dos gasodutos ${ }^{34}$ (EPE, 2014).

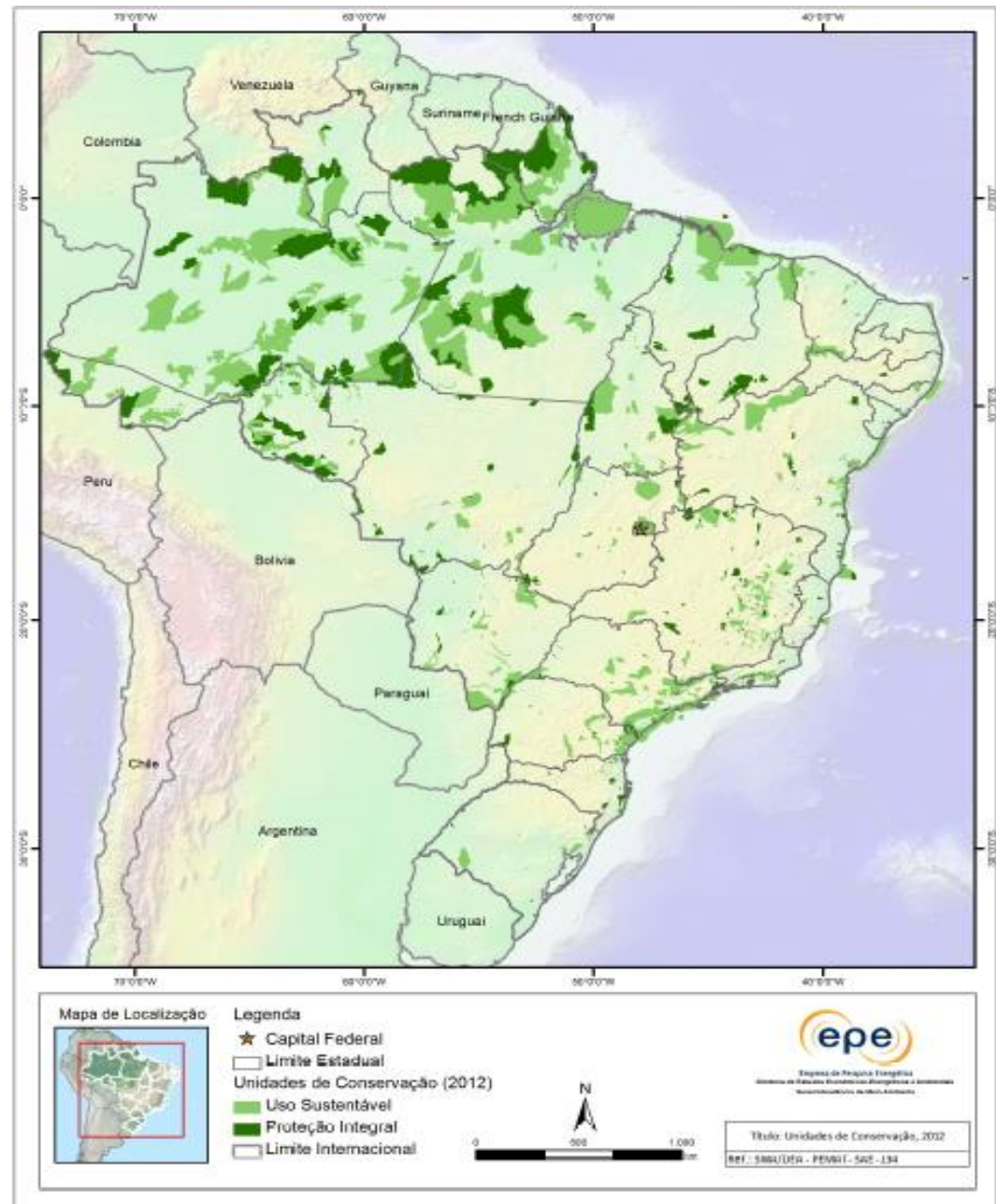

Figura 3.19 - Mapa de Unidades de conservação no Brasil

Fonte: PEMAT 2022 (EPE 2014)

\footnotetext{
${ }^{34}$ A fim de minimizar os impactos fora definidos alguns direcionamentos na definição dos traçados iniciais, como: preferência pelo acompanhamento de estradas existentes facilitando o acesso e reduzindo a necessidade de abertura de novas estradas; preferência por áreas com relevo de menor gradiente e áreas com menor suscetibilidade à erosão e movimentos de terra; cuidado com o ambiente atravessado pelo traçado preliminar, no que se refere ao número de corpos hídricos e à distância entre suas margens. priorização da alternativa com menor área de vegetação nativa; identificação da interferência do traçado inicial em outros empreendimentos lineares ( linhas de transmissão, rodovias e ferrovias).
} 


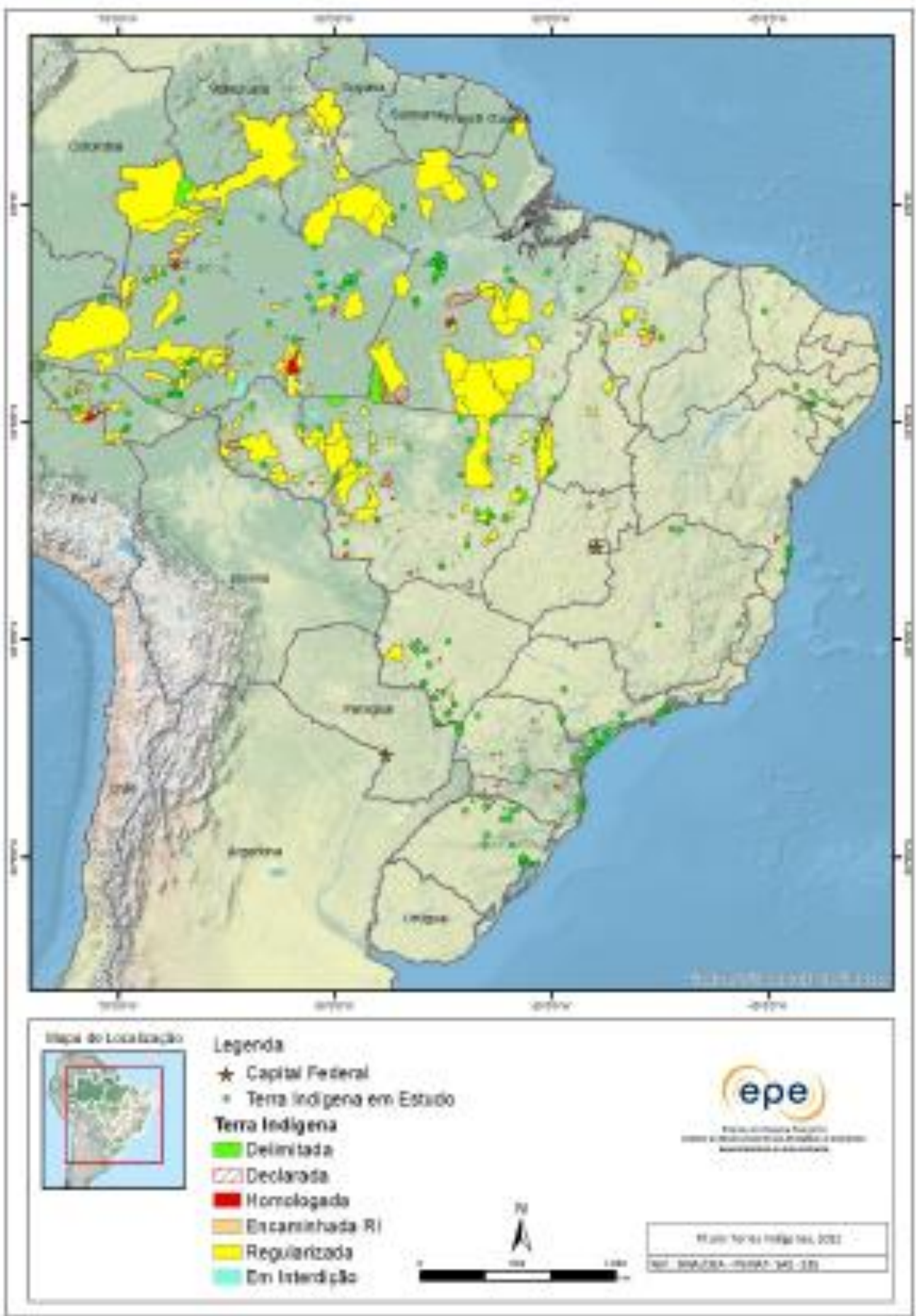

Figura 3.20 - Mapa das terras indígenas no Brasil

Fonte: PEMAT 2022 (EPE, 2014)

Já, na avaliação de projetos de duplicação de gasodutos existentes, são priorizados traçados que estejam na área de servidão. Caso não seja possível, a avaliação segue os 
mesmos cuidados de projetos de novos gasodutos para a definição do traçado inicial (EPE, 2014).

\subsection{6 Análise técnico econômica (EVTE) simplificado e detalhado}

Os estudos de análise técnico econômica, tanto o simplificado, quanto o detalhado, desenvolvidos no PEMAT 2022 contaram com uma avaliação utilizando figuras de mérito econômicas (EPE, 2014). Foram utilizadas para a avaliação de viabilidade, a partir da metodologia usual de fluxo de caixa descontado ${ }^{35}$, as seguintes figuras de mérito ${ }^{36}$ :

- Valor presente líquido (VPL);

- Taxa interna de retorno (TIR);

- Taxa mínima de atratividade (TMA);

A partir das premissas adotadas, obtém-se o valor da tarifa que contemple o interesse do investidor, e ao mesmo tempo, possa tornar o produto competitivo em relação aos seus combustíveis substitutos (EPE, 2014).

A parcela preço de oferta do gás natural especificado contém os custos de remuneração da atividade de exploração e produção, incluindo participações governamentais, atividade de compressão, escoamento e processamento do gás natural e venda dos líquidos de gás natural (EPE, 2014).

A parcela da tarifa de transporte deve arcar com os custos e os investimentos em infraestrutura associados ao transporte do gás natural até o city gate, sobre esta parcela há a incidência da seguinte carga tributária: i) investimento (II, IPI, ICMS, PIS/COFINS, IRRF, ISS e despesas aduaneiras); ii) resultado (IRPJ e CSLL) (EPE, 2014). A Figura 3.20 é a representação da constituição do preço final do gás natural no mercado.

\footnotetext{
${ }^{35}$ A metodologia do Fluxo de Caixa Descontado consiste na análise da geração dos montantes recebidos e gastos, em um especificado período de tempo. A partir do Fluxo de Caixa obtém-se as outras figuras de mérito econômicas como o Valor Presente Líquido (VPL), a Taxa Interna de Retorno (TIR) e a Taxa Mínima de Atratividade (TMA).

${ }^{36}$ O VPL equivale à diferença entre o valor atual (ou descontado) das entradas de caixa e o valor atual (ou descontado) das saídas decorrentes da realização do projeto de investimento para cada período, isto é, o valor presente do fluxo de caixa. A TIR expressa a rentabilidade da aplicação ou custo de financiamento ou empréstimo do fluxo de caixa. A Taxa Mínima de Atratividade (TMA) é uma taxa de desconto ou retorno que representa o mínimo que um investidor se propõe a ganhar em um projeto específico.
} 


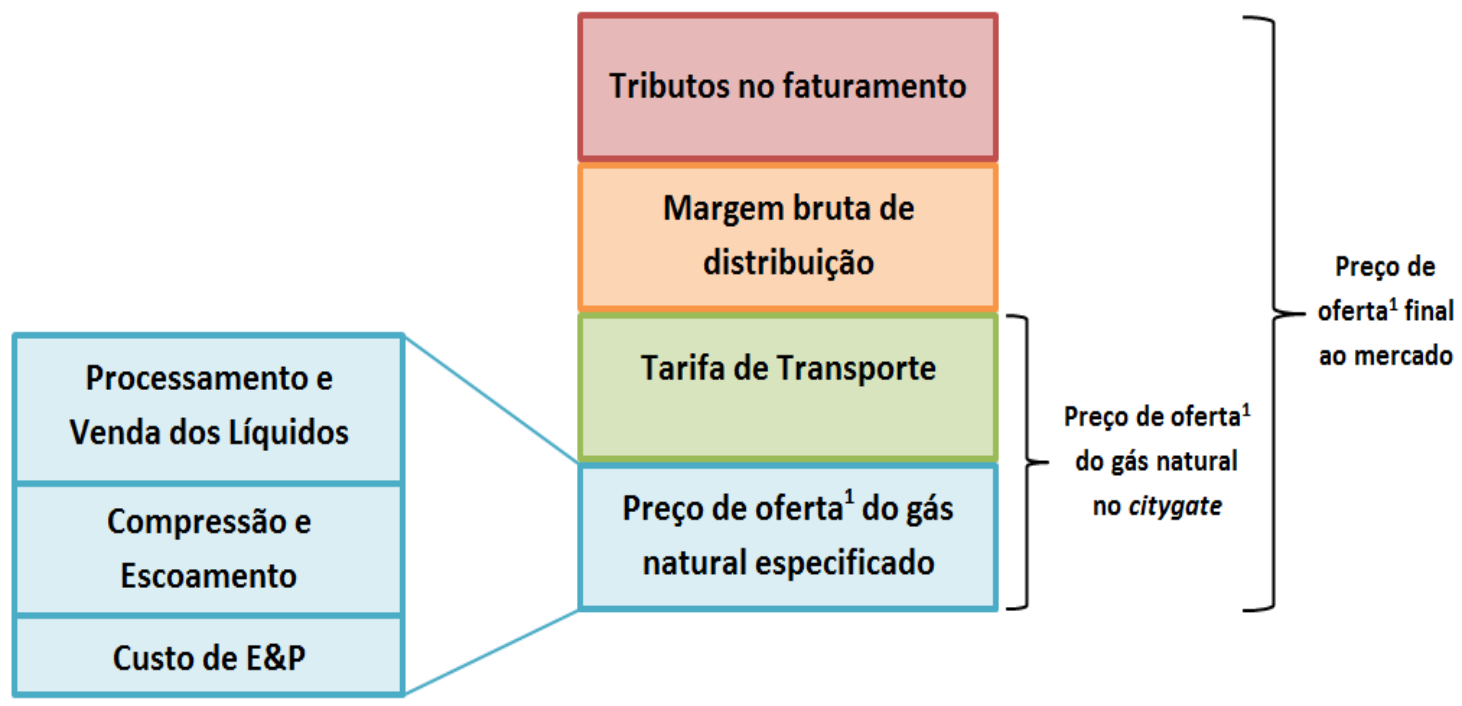

Figura 3.20 - Composição do preço final de gás natural ao mercado

Nota: 1 - "O preço de oferta é o preço mínimo que motiva o ofertante a disponibilizar o gás natural para o mercado." (PEMAT 2022, 21014).

Fonte: PEMAT 2022, (EPE, 2014)

A parcela margem bruta da distribuição remunera a atividade de distribuição; e finalmente a parcela de tributos no faturamento contempla a incidência de impostos sobre a comercialização do gás natural: PIS e COFINS (esfera federal) e ICMS (esfera estadual) (EPE, 2014).

Como já mencionado, a análise de viabilidade do projeto está condicionada ao preço de oferta final ao mercado que deve chegar ao consumidor por um preço igual ou menor que o preço do combustível substituto.

Então, para se obter a tarifa de transporte limite deve-se subtrair do preço máximo, que viabiliza a competitividade do gás natural no citygate, o custo econômico do gás natural especificado (EPE, 2014). Caso a tarifa estimada para o traçado seja igual ou inferior à tarifa limite, o traçado é considerado viável, caso contrário, o gasoduto não é viável economicamente. Este processo é ilustrado na Figura 3.21. 


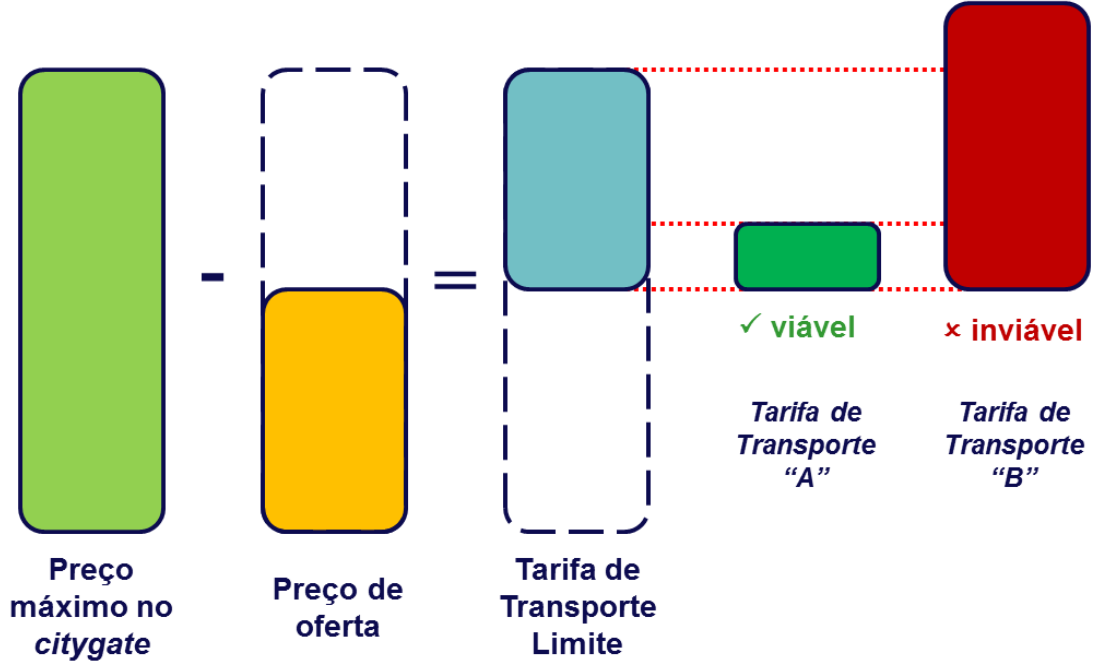

Figura 3.21 - Critérios para a tarifa de transporte estimada

Fonte: PEMAT 2022 (EPE, 2014)

O preço de oferta do gás natural especificado foi calculado por meio de análises ${ }^{37}$ de projetos nacionais típicos de produção de gás natural associado e não associado, onshore e offshore. Para o gás importado, consideram-se as cotações típicas para os volumes importados (GASBOL e terminais de regaseificação) (EPE, 2014). Na Tabela 3.7 os valores estimados e utilizados pela EPE no PEMAT 2022 são apresentados.

Uma vez estimado o preço de oferta do gás natural especificado, deve-se projetar o preço máximo no citygate a fim de se estimar a tarifa limite. O preço máximo no citygate foi calculado a partir do preço do combustível substituto, decrescido dos impostos e da margem da distribuidora (EPE, 2014). NaTabela 3.8 são apresentados os valores de preço máximo no citygate para cada distribuidora do território brasileiro.

\footnotetext{
37 “As análises levaram em consideração (i) as características dos reservatórios; (ii) a composição do gás natural; (iii) os custos relativos às atividades de E\&P do gás natural; (iv) a incidência de Participações Governamentais; (v) os custos de compressão, escoamento e processamento do gás natural; (vi) a venda dos líquidos de gás natural; e (vii) uma taxa de retorno mínima para o projeto.” (EPE, 2014)
} 
Tabela 3.7 - Preço de oferta do gás natural especificado

Preço de oferta do gás natural especificado nacional [US\$MMBtu] - projetos típicos

\begin{tabular}{lc}
\hline \hline Gás Não Associado - Campos em Terra & 1,13 \\
Gás Não Associado - Campos no Mar (Pós-Sal) & 4,73 \\
\hline Gás Associado - Campos em Terra & 0,56 \\
Gás Associado - Campos no Mar (Pós-Sal) & 4,95 \\
\hline Gás Associado - Campos no Mar (Pré-Sal) - 1 módulo de produção & 7,70 \\
Gás Associado - Campos no Mar (Pré-Sal) - 2 módulos de produção & 5,59 \\
Gás Associado - Campos no Mar (Pré-Sal) - 3 módulos de produção & 5,04 \\
Gás Não Convencional - Campos em Terra & 6,00 \\
\hline \multicolumn{1}{c}{ Preço de oferta do gás natural especificado importado [US\$/MMBtu] - cotações típicas } \\
\hline \hline Importado via GASBOL & 9,58 \\
Importado via Terminal de Regaseificação da Baía de Guanabara/RJ & 15,7 \\
Importado via Terminal de Regaseificação de Pecém/CE & 16,65 \\
\hline
\end{tabular}

Fonte: PEMAT 2022 (EPE, 2014).

Tabela 3.8 - Preço máximo do gás natural no citygate para cada distribuidora considerando 1005 de competitividade com o óleo combustível

\begin{tabular}{|c|c|c|}
\hline Empresa & $\begin{array}{l}\text { Unidade da } \\
\text { Federação }\end{array}$ & $\begin{array}{c}\text { Preço máximo do gás natural no } \\
\text { citygate (US\$/MMBtu) }\end{array}$ \\
\hline CEGÁS & $\mathrm{CE}$ & 12,78 \\
\hline POTIGÁS & $\mathrm{RN}$ & 12,01 \\
\hline PBGÁS & $\mathrm{PB}$ & 10,85 \\
\hline COPERGÁS & $\mathrm{PE}$ & 9,98 \\
\hline ALGÁS & $\mathrm{AL}$ & 7,62 \\
\hline SERGAS & SE & 11,01 \\
\hline BAHIAGAS & $\mathrm{BA}$ & 9,04 \\
\hline GASMAR & MA & 12,01 \\
\hline GASMIG & MG & 11,89 \\
\hline PETRO ES & ES & 11,08 \\
\hline CEGÁS & RJ & 10,75 \\
\hline CEG RIO & RJ & 10,98 \\
\hline COMGÁS & SP & 8,6 \\
\hline Gas Natural Fenosa & SP & 8,59 \\
\hline COMPAGAS & PR & 7,99 \\
\hline SCGÁS & $\mathrm{SC}$ & 9,11 \\
\hline SULGAS & $\mathrm{RS}$ & 10,44 \\
\hline GASPARÁ & $\mathrm{PA}$ & 10,24 \\
\hline CIGAS & $\mathrm{AM}$ & 12,83 \\
\hline MSGÁS & MS & 11,37 \\
\hline
\end{tabular}

Fonte: PEMAT 2022 (EPE,2014) 
Para avaliar o valor da tarifa de transporte, que tornaria o investimento atrativo, a EPE considerou a situação onde a TIR é equivalente à TMA adotada. Para o cálculo da tarifa foram adotadas premissas destacadas na Tabela 3.9. Estes cálculos levaram em consideração os benefícios do Regime Especial de Incentivos para o Desenvolvimento da Infraestrutura (REIDI) ${ }^{38}$. (EPE, 2014).

\section{Tabela 3.9 - Premissas adotadas pela EPE na análise econômica}

\section{Premissas adotas pela EPE no EVTE}

\begin{tabular}{lc}
\hline \hline Vida útil do projeto & 30 anos \\
\hline Venda durante o período do projeto & $100 \%$ \\
\hline Compensação ambiental & $0,5 *$ CAPEX \\
\hline Período de investimento & $0,3 *$ investimento \\
\hline \hline 1 ano & $0,3 *$ investimento \\
2 ano & $0,4 *$ investimento \\
3 ano & gasoduto em operação \\
4 ano & $4 \%$ a.a.(investimento) \\
\hline OPEX & $4 \%$ a.a.(investimento) \\
\hline Depreciação & $7,5 \%$ a.a. (investimento) \\
\hline TMA & $9,64 \%$ a.a. \\
\hline Custo do capital próprio & $7,89 \%$ \\
\hline Taxa de juros & $52,77 \%$ \\
\hline Percentual financiado & $25 \%$ LAIR anual \\
\hline IRPJ & $9 \%$ LAIR anual \\
\hline CSLL & $30 \%$ \\
\hline Prejuízo fiscal em cada período & \\
\hline &
\end{tabular}

Fonte: Elaboração própria com dados do PEMAT 2022

A forma de cálculo do custo do capital próprio, da taxa de juros e do custo médio ponderado de capital são apresentadas na Tabela 3.10.

\footnotetext{
38 Sistema especial de tributação instituído pela Lei $n^{\circ}$. 11.488/07 e regulamentado pelo Decreto $n^{\circ}$. 6.144/2007, a finalidade deste sistema é reduzir os custos de projetos de infraestrutura nos setores de transportes, portos, energia, saneamento básico e irrigação. A redução ocorre através da redução nas alíquotas de PIS/PASEP, COFINS, PIS/PASEP-Importação e COFINS-Importação na aquisição de máquinas, aparelhos, instrumentos e equipamentos, e de novos materiais de construção para a utilização ou incorporação em obras de infraestrutura destinadas ao ativo imobilizado do beneficiário.
} 
Tabela 3.10 - Custo de capital próprio ( $\%$ ao ano), taxa de juros e custo médio ponderado de capital

\begin{tabular}{|c|c|}
\hline Custo de capital próprio real $\quad r_{P}=r_{f}+\beta\left(r_{m}-r_{f}\right)+r_{B}{ }^{1}$ & $9,64 \%$ \\
\hline Imposto $(\mathrm{T})$ & $34,00 \%$ \\
\hline Estrutura de capital de terceiros $[\mathrm{D} /(\mathrm{P}+\mathrm{D})]$ & $52,77 \%$ \\
\hline Taxa livre de risco $\left(r_{f}\right)$ & $4,66 \%$ \\
\hline Beta empresas de transporte de gás natural realavancado $(h)$ & $1,02 \%$ \\
\hline Spread de risco de mercado $\left(\boldsymbol{r}_{\boldsymbol{m}}-\boldsymbol{r}_{f}\right)$ & $5,34 \%$ \\
\hline Prêmio de risco de negócio e financeiro $\left[\boldsymbol{\beta}\left(\boldsymbol{r}_{\boldsymbol{m}}-\boldsymbol{r}_{f}\right)\right]$ & $5,43 \%$ \\
\hline Prêmio de risco de investimento no Brasil $\left(\boldsymbol{r}_{\boldsymbol{B}}\right)$ & $2,24 \%$ \\
\hline Prêmio de risco regulatório $\left(r_{r}\right)$ & $0,00 \%$ \\
\hline Inflação Americana (CPI) & $2,45 \%$ \\
\hline Custo de capital próprio nominal $\boldsymbol{r}_{\boldsymbol{P}}=\boldsymbol{r}_{f}+\boldsymbol{\beta}\left(\boldsymbol{r}_{m}-\boldsymbol{r}_{f}\right)+\boldsymbol{r}_{\boldsymbol{B}}+\boldsymbol{r}_{r}$ & $12,33 \%$ \\
\hline Taxa de Juros (Financiamento BNDES) $\quad r_{D}=\left[\frac{1+\left(T J P L+1 \%+s_{1}\right)}{1+I P C A}-1\right]$ & $\mathbf{7 , 8 9 \%}$ \\
\hline Participação da modalidade direta & $50,00 \%$ \\
\hline TJLP (média) & $6,62 \%$ \\
\hline IPCA (média) & $5,52 \%$ \\
\hline Remuneração Básica BNDES & $1,30 \%$ \\
\hline Intermediação Financeira BNDES & $0,50 \%$ \\
\hline Taxa de Risco de Crédito & $4,18 \%$ \\
\hline Intermediação Instituição Financeira Credenciada & $1,00 \%$ \\
\hline Custo médio real (WACC) $\quad r_{W A C C}=\frac{P}{P+D} * r_{P}+\frac{D}{P+D} * r_{P} *(1-T)$ & $7,30 \%$ \\
\hline
\end{tabular}

Fonte: Adaptação de PEMAT 2022 (EPE, 2014)

Como já explicado na secção 3.3, existem dois estudos de viabilidade técnica e econômica diferentes. No EVTE simplificado esta análise é feita a partir do valor do "metro.pol", obtido a partir do levantamento de custos de outros gasodutos. Desta forma calcula-se um valor médio do custo para a unidade do duto identificada, já que estas são usualmente identificadas em metros e polegadas. $\mathrm{O}$ custo em metropol corresponde ao valor em dólares americanos a cada metro de duto de uma polegada construído (EPE, 2014).

O custo médio dos dutos pode variar por diversos fatores, o EVTE simplificado não é um estudo suficiente, a EPE o considerou adequado como uma etapa de análise inicial, já que existe a EVTE detalhada onde estes custos serão estimados levando em consideração às complexidades de cada alternativa (EPE, 2014). 
A média brasileira foi obtida a partir dos valores dos vinte gasodutos construídos no país, como ilustrado na Figura 3.22. Esta média foi de US\$123,34/m.pol. Este valor é alto, a média americana para os projetos mais recentes (2011 e 2012) é de US\$ 70/m.pol, como pode ser observado na Figura 3.23.

Em ambas figuras, nota-se a discrepância de alguns projetos, da média brasileira foram retirados projetos que excederam US\$ 200,00/m.pol e a média ajustada foi de US\$ 91,23/m.pol.

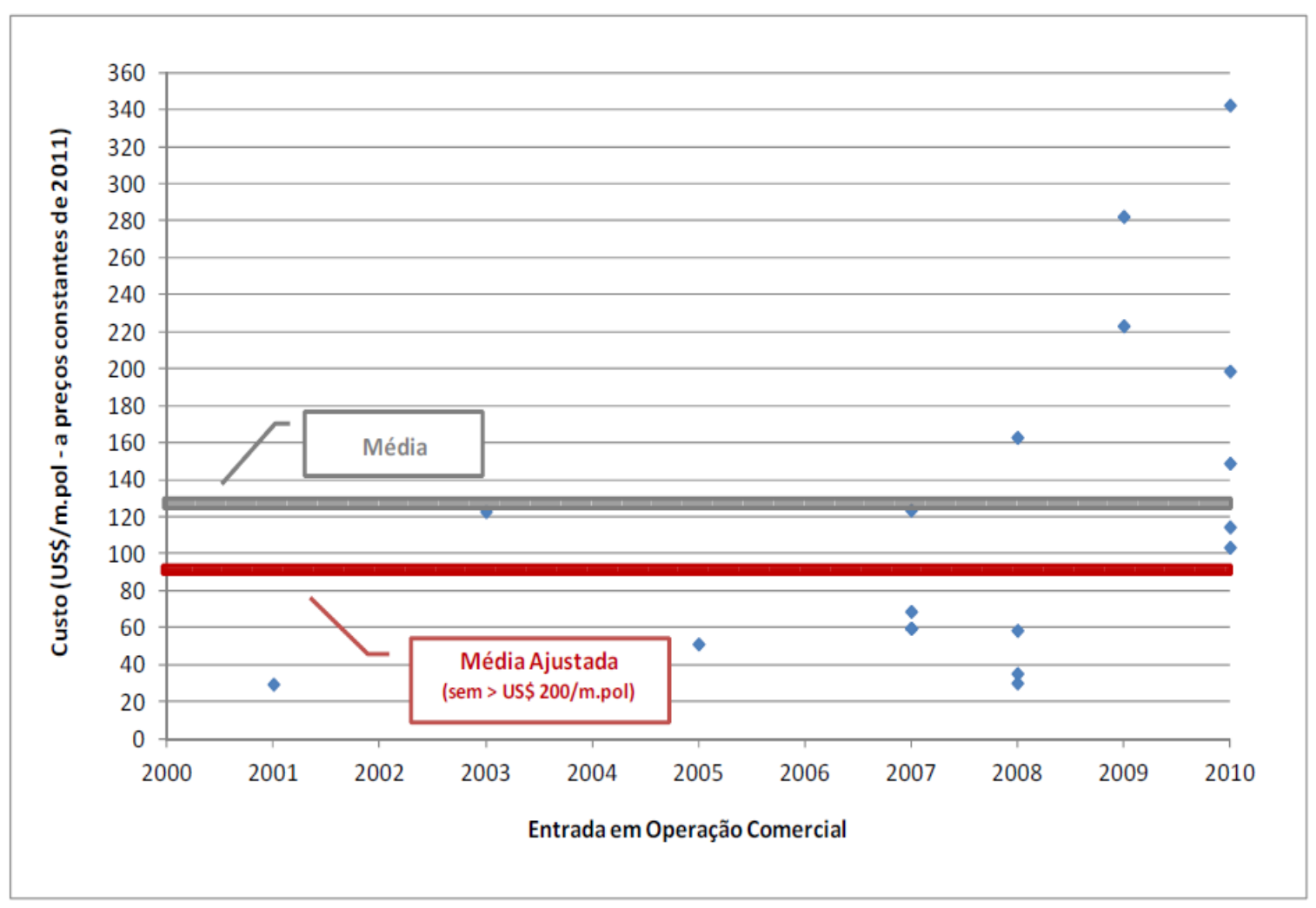

Figura 3.22 - Custo Médio de gasodutos no Brasil

Fonte: PEMAT 2022 (EPE (2014) dados ANP(2012)) 


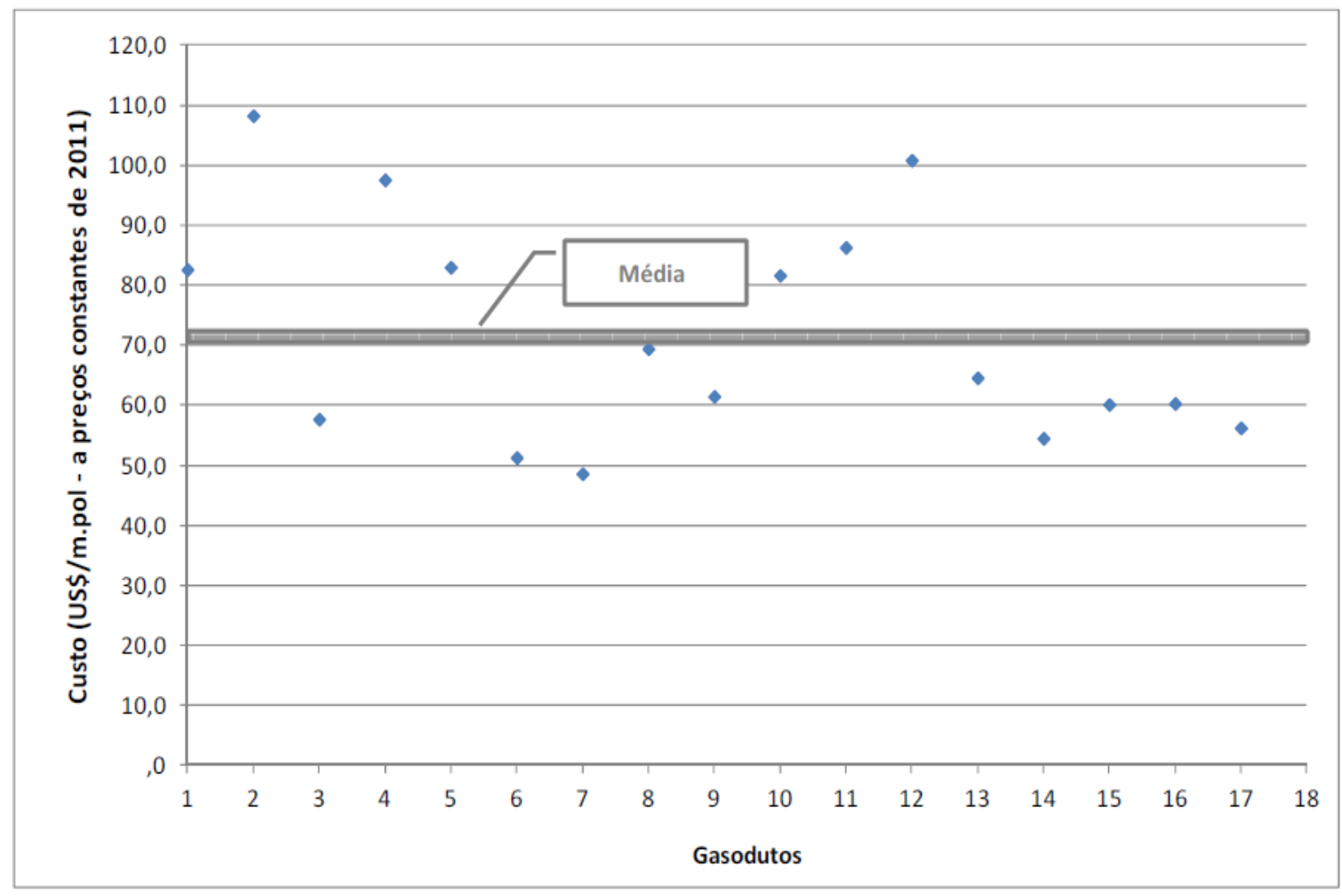

Figura 3.23 - Custo Médio de gasodutos nos EUA em 2011-2012

Fonte: PEMAT 2022 (EPE, 2014, dados EIA (2013))

No entanto, novos projetos de gasodutos de transporte serão licitados de acordo com a Lei 11.909/2009, e este processo vale-se de um critério de seleção onde a proposta vencedora será o de menor receita anual. Desta forma, é de se esperar que a média brasileira aproxime-se de valores internacionais. Assim, a EPE decidiu adotar, nesta etapa (EVTE simplificado), a média de US\$ 80,00/m.pol (EPE, 2014).

Para os projetos que foram considerados viáveis após a EVTE simplificada, em etapa posterior, a EPE realiza um EVTE detalhado. Nesta análise, é utilizado o sistema SAGAS, que é ilustrado na Figura 3.24 (EPE, 2014). O cálculo dos custos utiliza informações de bases de dados históricas, catálogos de equipamentos, contato com fornecedores e publicações técnicas. Essas informações se encontram em diversos graus de agregação (EPE, 2014). Nessa etapa, a avaliação técnica do local de caminhamento do duto é essencial para a análise de custos. São consideradas, além das características físicas de escoamento, as principais condições referentes à instalação dos dutos como a topografia do terreno, uso do solo, densidade demográfica no entorno à faixa de servidão, 
ocorrências de leitos de água, cobertura e geologia do solo e o índice pluviométrico da região. Esta avaliação é feita na faixa de servidão de $20 \mathrm{~km}$ (EPE, 2014).

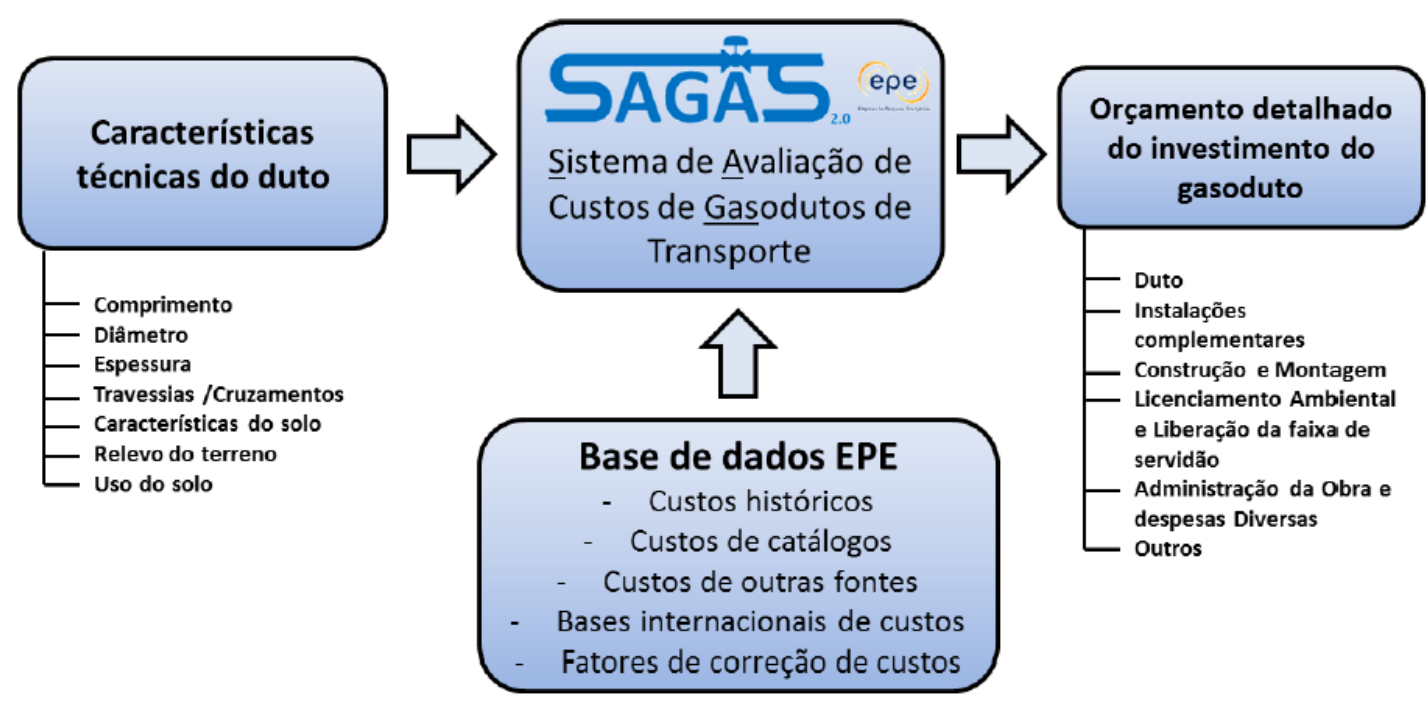

Figura 3.24 - Resumo do fluxo de informações envolvidas no processo de avaliação de gasodutos.

Fonte: PEMAT 2022 (EPE, 2014)

\subsection{Análise das proposições - "resultados do PEMAT 2022"}

Em função da avaliação da demanda e da oferta para o PDE 2022, as alternativas apresentadas na Figura 3.25 foram avaliadas, por caracterizarem projetos que, uma vez considerados viáveis dentro da metodologia adotada no PEMAT 2022, poderiam ser propostos aos investidores por iniciativa do MME (EPE, 2014). Sendo eles:

- Bacia do Parnaíba/MA-PI - Barcarena/PA (sistema isolado);

- Bacia do São Francisco/MG ou Malha Integrada Sudeste - MG (sistema integrado);

- COMPERJ, Itaboraí/RJ - Malha Integrada Sudeste - RJ (sistema integrado);

- GASBOL - Triângulo Mineiro/MG (sistema integrado);

- GASBOL ou Malha Integrada Sudeste - Região Sul (sistema integrado);

- Malha Integrada, ES ou RJ - Vale do Aço/MG (sistema integrado). 


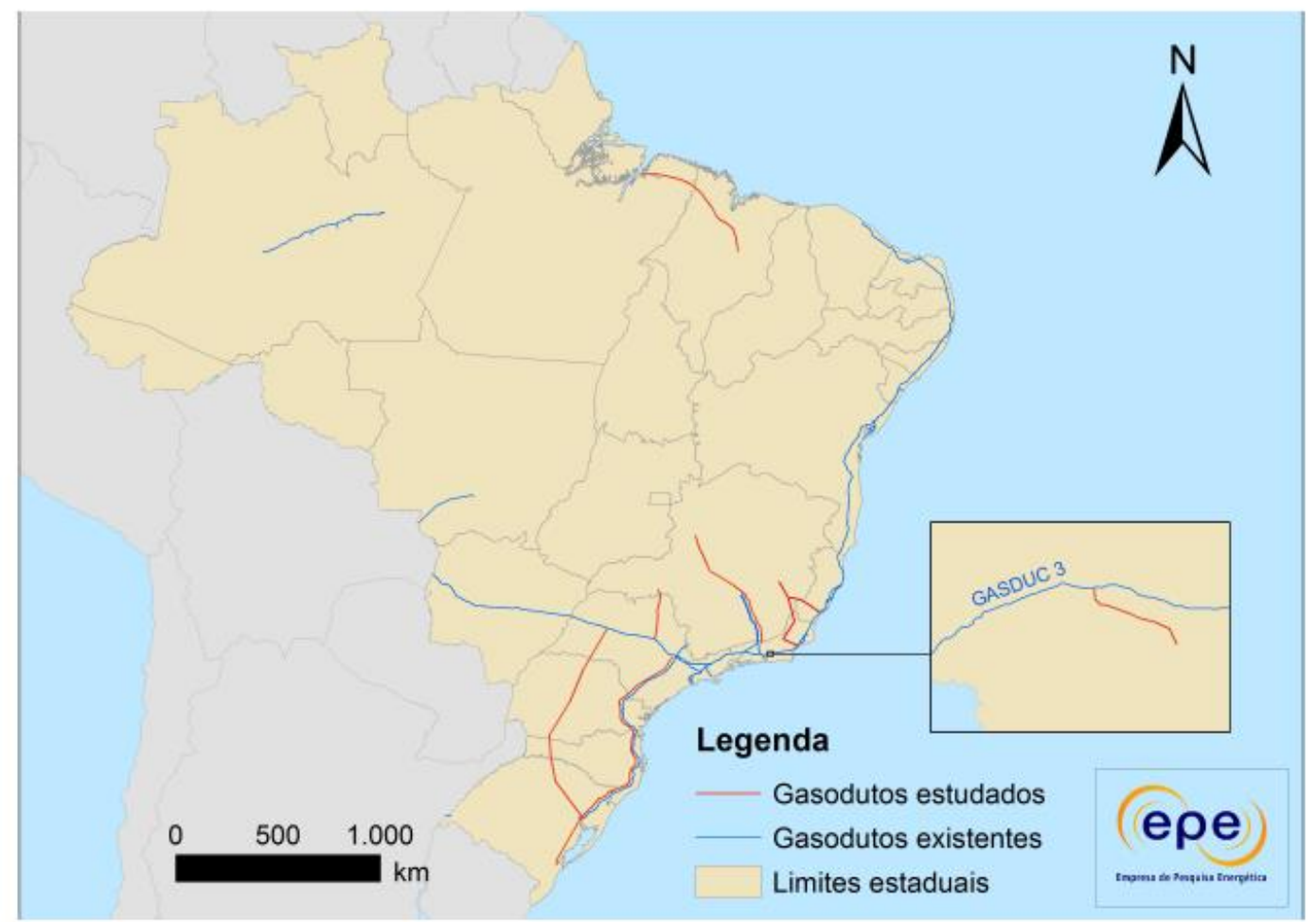

Figura 3.25 - Alternativas estudadas de interligação de origem-destino

Fonte: PEMAT 2022 (EPE 2014)

As alternativas de gasodutos Itaboraí/RJ - Guapimirim/RJ e São Carlos/SP Uberaba/MG foram avaliadas, e, inicialmente, estavam entre as opções de proposições por iniciativa do MME. Contudo, a EPE decidiu retirá-los da carteira de opções, uma vez que outros estudos similares, e em estágios mais avançados, já se encontravam em outros encaminhamentos ${ }^{39}$ (EPE, 2014).

No entanto, após a conclusão dos estudos do PEMAT 2022, o gasoduto Itaboraí/RJ - Guapimirim/ RJ, foi objeto de provocação por terceiros, e, portanto, incorporado ao estudo. Como o nível de detalhamento deste gasoduto apresentava-se em estágio mais avançado ele não consta nas análises iniciais do PEMAT 2022 (EPE, 2014).

$\mathrm{Na}$ Tabela 3.11 são apresentadas as alternativas inicialmente estudadas e as características de cada traçado. ${ }^{40}$

\footnotetext{
${ }^{39}$ A alternativa São Carlos/SP-Uberaba/MG é um projeto cujo estágio de maturidade é superior ao dos estudos do PEMAT 2022. O projeto Brasil Central da Transportadora de Gás Brasil Central S.A. - TGBC. Processo de outorga de autorização encontrava-se em fase de elaboração de edital para chamada pública junto à ANP63 (vide TGBC, 2013).

40 “A elaboração destas alternativas, nesta fase, assumiu uma distância em linha reta dos pontos notáveis ao longo do trajeto, à exceção daquelas alternativas que partiram da ampliação de gasodutos existentes,
} 
Tabela 3.11 - Caracterização básica das alternativas identificadas nos estudos do PEMAT 2022

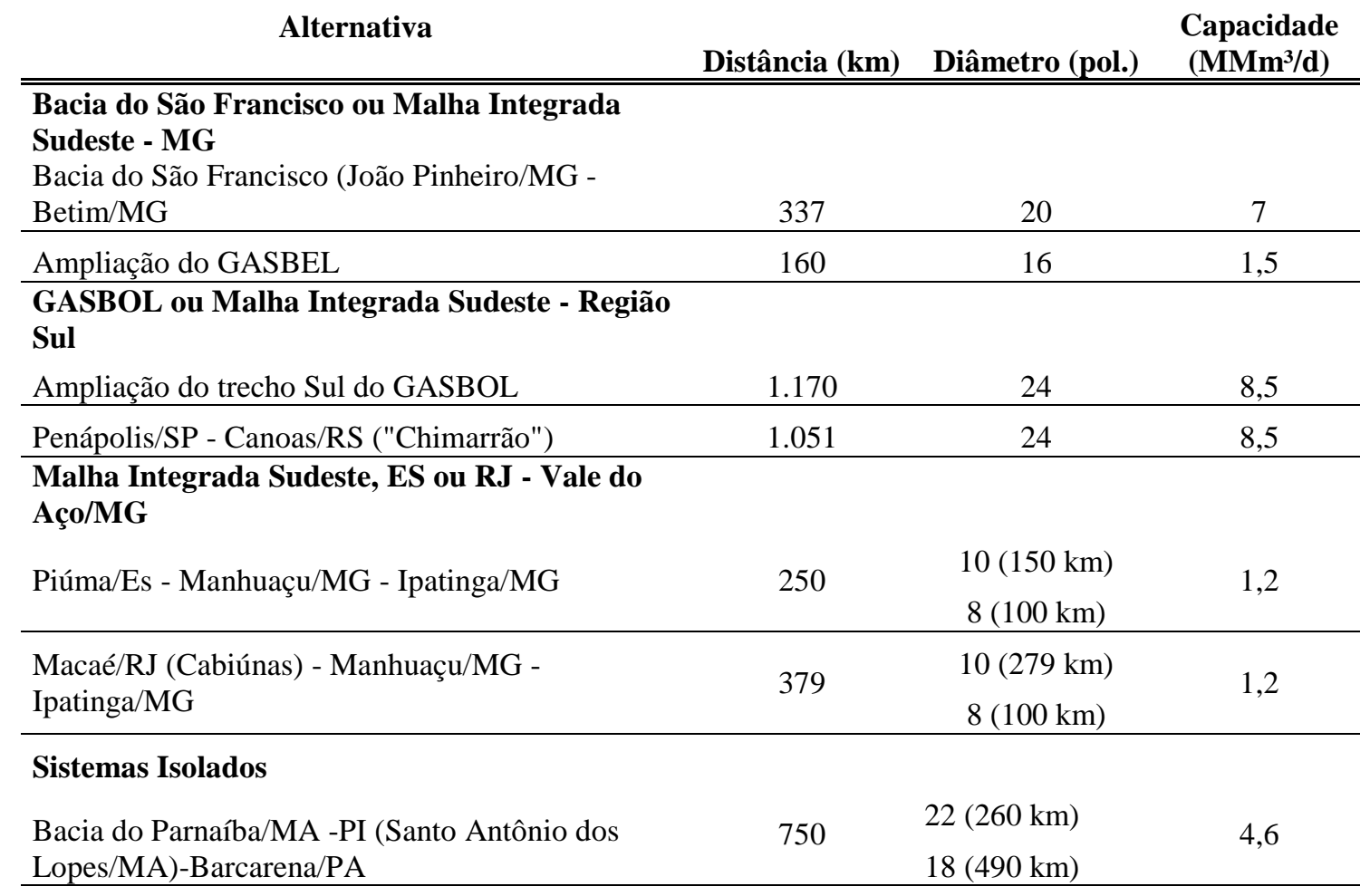

Fonte: PEMAT 2022 (EPE,2014).

Determinadas as características dos traçados preliminares das alternativas identificadas na Tabela 3.11, foi feita a análise técnica e econômica simplificada (EVTE simplificado). Na Tabela 3.12 são apresentados os resultados desta análise. E a partir dos valores da tarifa limite é avaliada inicialmente a viabilidade técnica e econômica das alternativas.

O balanço de oferta e demanda para as alternativas foi feito através da simulação fluido-termo-hidráulica segundo as seguintes considerações:

- Despacho máximo para as usinas termelétricas, onde todas as usinas são supridas com gás natural, até mesmo as bicombustíveis; 
Tabela 3.12 - Estimativas de custos de investimento e tarifas de transporte das alternativas identificadas nos estudos do PEMAT 2022 - EVTE Simplificado

\begin{tabular}{|c|c|c|}
\hline Alternativa & $\begin{array}{c}\text { CAPEX (R\$ } \\
\text { Milhões) }\end{array}$ & $\begin{array}{c}\text { Tarifa* } \\
\text { (US\$/MMBtu) } \\
\end{array}$ \\
\hline \multicolumn{3}{|l|}{ Bacia do São Francisco ou Malha Integrada Sudeste - MG } \\
\hline Bacia do São Francisco (João Pinheiro/MG - Betim/MG & 1.095 & 0,97 \\
\hline Ampliação do GASBEL & 415 & 1,66 \\
\hline \multicolumn{3}{|l|}{ GASBOL ou Malha Integrada Sudeste - Região Sul } \\
\hline Ampliação do trecho Sul do GASBOL & 4.600 & 3,08 \\
\hline Penápolis/SP - Canoas/RS ("Chimarrão") & 4.200 & 2,8 \\
\hline \multicolumn{3}{|l|}{ Malha Integrada Sudeste, ES ou RJ - Vale do Aço/MG } \\
\hline Piúma/Es - Manhuaçu/MG - Ipatinga/MG & 374 & 1,87 \\
\hline Macaé/RJ (Cabiúnas) - Manhuaçu/MG - Ipatinga/MG & 583 & 2,92 \\
\hline $\begin{array}{l}\text { Sistemas Isolados } \\
\text { Bacia do Parnaíba/MA -PI (Santo Antônio dos Lopes/MA)- } \\
\text { Barcarena/PA }\end{array}$ & 2.360 & 3,08 \\
\hline
\end{tabular}

Notas: * Tarifa de referência para avaliação. Ressalta-se que a Tarifa Máxima de transporte para a chamada pública será definida pela ANP com o apoio da EPE, em etapa posterior do PEMAT.

Fonte: PEMAT 2022 (EPE,2014).

- Não foram consideradas as demandas termelétricas indicativas ${ }^{41}$. Assim como, também não foram considerados os volumes de oferta de gás natural associados ao atendimento desta demanda;

- Considerou-se a expansão da capacidade de liquefação de GNL no terminal da Baia de Guanabara e a entrada em operação do terminal de GNL na Bahia. Projetos de terminais de GNL previstos para o horizonte decenal mas ainda em fase de avaliação ou indefinidos ${ }^{42}$ não foram considerados no PEMAT 2022;

- A oferta do GASBOL permanece em 30 milhões de m²/dia;

- Não foram consideradas as ofertas de sistemas isolados Lateral Cuiabá e Uruguaiana- Porto Alegre Trecho 1, uma vez que as térmicas foram consideradas

\footnotetext{
${ }^{41}$ Este desconto só ocorreu porque a localização das usinas termelétricas ligadas ao SIN é obtida através do sistema de leilão de energia nova (LEN), sem a localização não há possibilidade de incluir este ponto na malha, já que a localização das usinas interfere nos resultados da simulação.

42 Alguns projetos foram anunciados mas ainda carecem de definição é o caso do terminal Barra do Riacho/ES (capacidade de 14 Milhões de $\mathrm{m}^{3} / \mathrm{dia}$ ) ainda em avaliação pela Petrobrás; terminal de regaseificação de GNL em Rio Grande/RS, Tergas do grupo Bolognesi; terminal de regaseificação de GNL da Petrobrás- Samsung-Hyundai em Rio Grande/RS ou Tramandaí/RS; terminal de regaseificação de GNL da Eletronorte - Gaspará - Termogás em Vila do Conde, Bacarena/PA (sistema isolado).
} 
em despacho máximo, esta oferta já estaria comprometida com as térmicas Governador Mario Covas e AES Uruguaiana;

- Houve a inclusão da demanda em Uberaba, do projeto São Carlos-Uberaba, não considerado entre as alternativas avaliadas por estar em um estágio mais avançado de estudo (EPE, 2014).

A simulação termo-fluído-hidráulica ainda apresentou os seguintes "resultados":

- A identificação de demandas potenciais adicionais no estado de Minas Gerais e na Região Sul;

- A necessidade de exportação da malha da Região Sudeste da Petrobrás simultaneamente para o GASBOL ${ }^{43}$ e para a malha da Região Nordeste através do GASENE;

- No estado de Minas Gerais foi considerada uma oferta de Recursos Contingentes (RC) e Recursos Não Descobertos (RND) no final do período para atender a demanda potencial adicional. Assim foi definida a alternativa a partir do centro geométrico da bacia do São Francisco, sem a confirmação desta oferta seriam necessárias ampliações no GASBEL;

- A demanda de Uberaba, que em projeto indicado deveria ser suprida através de um duto oriundo pelo GASBOL, nesta simulação mostrou-se inviável, tendo de ser suprida pela ampliação do GASBEL;

- A Região Sudeste acrescida das necessidades do GASBOL e do GASENE demandaria os 20 milhões de $\mathrm{m}^{3} /$ dia do terminal de regaseificação de GNL da Baia de Guanabara, além da necessidade de que as térmicas a bicombustível sejam despachadas com combustível substituto;

- Para o sistema isolado a alternativa identificada Santo Antônio dos Lopes/MA Barcarena/PA, a oferta potencial é composta em parte por Recursos Descobertos (RD) da Bacia do Parnaíba/MA-PI, que já está comprometida com a demanda térmica de uma termelétrica, assim os volumes de oferta associados a esta alternativa referem-se a Recursos Não Descobertos (RND) (EPE, 2014).

\footnotetext{
43 Através da simulação ficou claro a incapacidade de despachar completamente as térmicas de Araucária e Canoas através da infraestrutura atual desta malha, além da necessidade de um volume de cerca de 17 milhões de $\mathrm{m}^{3} / \mathrm{dia}$, quando a malha Sudeste só dispõe de 12 milhões de $\mathrm{m}^{3} /$ dia para deslocar ao GASBOL. A entrada de algum dos terminais de regaseificação de GNL previstos para a região poderá modeificar o balanço de oferta e demanda, que na simulação foi negativo.
} 
A análise de viabilidade técnica e econômica foram realizadas para as alternativas Bacia do São Francisco (João Pinheiro/MG - Betim/MG) e para a Bacia do Parnaíba (Santo Antônio dos Lopes/MA) - Barcarena/PA. Ambas as alternativas foram avaliadas viáveis no EVTE detalhado como mostra a Tabela 3.13.

Tabela 3.13 - Análise de viabilidade técnica e econômica

\begin{tabular}{|c|c|c|}
\hline Opção de Interligação & $\begin{array}{l}\text { Bacia do São Francisco (João } \\
\text { Pinheiro/MG)-Betim/MG }\end{array}$ & $\begin{array}{c}\text { Bacia do Parnaíba (Santo } \\
\text { Antônio dos Lopes/MA) - } \\
\text { Barcarena/PA } \\
\end{array}$ \\
\hline $\begin{array}{l}\text { Tipo de produção - } \\
\text { Preço de oferta } \\
\text { [US\$/MMBtu] }\end{array}$ & $\begin{array}{c}\text { Gás Não Associado - Campos em Terra } \\
\text { / US\$ 1,13/MMBtu } \\
\text { Gás Associado - Campos em Terra/ } \\
\text { US\$ 0,56/MMBtu }\end{array}$ & $\begin{array}{c}\text { Gás Não Associado - Campos em } \\
\text { Terra / US\$ 1,13/MMBtu }\end{array}$ \\
\hline $\begin{array}{l}\text { Preço máximo do gás } \\
\text { natural no citygate } \\
\text { [US\$/MMBtu] }\end{array}$ & US\$ 11,89/MMBtu & US\$ 10,24/MMBtu \\
\hline $\begin{array}{c}\text { Tarifa máxima de } \\
\text { transporte } \\
\text { [US\$/MMBtu] }\end{array}$ & $\begin{array}{c}\text { Gás Não Associado - Campos em Terra } \\
\text { / US\$ 11,33/MMBtu } \\
\text { Gás Associado - Campos em Terra/ } \\
\text { US\$ 10,76/MMBtu }\end{array}$ & US\$ 9,11/MMBtu \\
\hline $\begin{array}{l}\text { Tarifa de transporte - } \\
\text { EVTE Detalhado }\end{array}$ & $\begin{array}{c}\text { US\$ 2,14/MMBtu < } \\
\text { US\$10,76/MMBtu }\end{array}$ & $\begin{array}{c}\text { US\$ 3,22/MMBtu }<\text { US\$ } \\
\text { 9,11/MMBtu }\end{array}$ \\
\hline
\end{tabular}

Os resultados do balanço de oferta e demanda para as alternativas, assim como os do EVTE, são apresentados na Tabela 3.14.

A EPE inicia o capítulo 4 do PEMAT 2022 apontando que nenhuma das alternativas propostas por iniciativa própia foi considerad elegível, apenas levando adiante o Gasoduto de Transporte denominado Guapimirim-COMPERJ II (EPE, 2014). Esse resultado corresponde a uma expansão de $11 \mathrm{~km}$ no horizonte decenal. Sendo assim, é fundamental analisar de forma crítica o PEMAT 2022 com a finalidade de se compreender, acompanhar e participar do planejamento setorial. 
Tabela 3.14 - Avaliação das alternativas identificadas para aprofundamento nos estudos do PEMAT 2022 pelos critérios de balanço de oferta e demnda e tarifa de transporte - EVTE simplificado

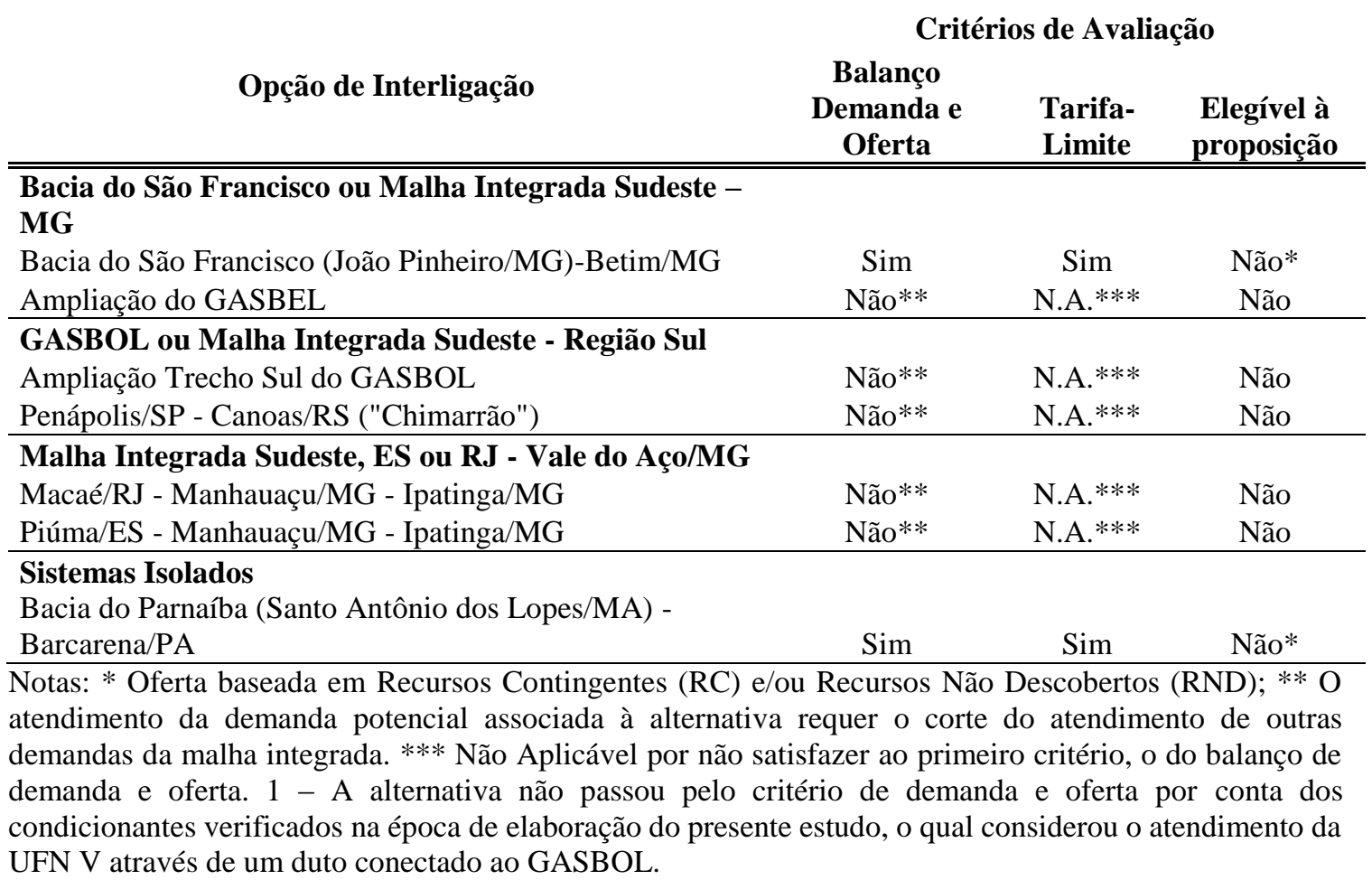

Fonte: PEMAT 2022 (EPE,2014).

\subsection{Considerações finais do capítulo}

A Lei do Gás trouxe as bases para a expansão do mercado brasileiro de gás natural e com a reformulação do papel do MME, ocorreu, em 2013, a elaboração do PEMAT 2022 pela EPE.

Nessa linha, o PEMAT 2022 avaliou projetos de gasodutos dentro dos critérios oferta, demanda e planejamento energético.

Todavia, os resultados do PEMAT 2022 apontam para um cenário decenal infímo em termos de expansão da malha de gasodutos. Por tal motivo, entende-se que se tornou crucial analisar de forma crítica o PEMAT 2022 para fins de se sugerir modificações que incrementem tais resultados. Considerando isso, o capítulo 4 apresenta a análise crítica e, ao final, sugestões para se aperfeiçoar o PEMAT 2022 ou estudo semelhante que lhe venha substituir. 


\section{ANÁLISE CRÍTICA DO PEMAT 2022}

\subsection{Introdução}

Como se percebe do capítulo 3, os argumentos que basearam os resultados do PEMAT 2022 focaram, sobretudo, na ausência de oferta de gás natural como fator de inviabilização de projetos.

Nesse sentido, com o objetivo de comparar as projeções de oferta e demanda do PEMAT 2022, analisou-se as projeções de agências internacionais (EIA e IEA) e do Plano Decenal de Energia (EPE).

A análise comparada desses dados e informações provenientes dessas fontes foi apresentada em forma de artigo científico no IX Congresso Brasileiro de Planejamento Energético $^{44}$. Os itens 4.2, 4.3 e 4.4 apresentam uma síntese da análise publicada, bem como acréscimos decorrentes do amadurecimento da presente pesquisa.

O tópico 4.5 trata da das considerações finais sobre oferta e demanda. $\mathrm{O}$ item 4.6 apresenta a crítica do modelo de inserção do gás existente no PEMAT 2022 do ponto de vista do planejamento energético, assim como o tópico 4.7 dar continuidade à anáçise crítica a partir de considerações sobre o consumo de energia no Brasil e o crescimento da geração termelétrica a gás natural. O ponto 4.8 apresenta considerações finais do capítulo e a proposição dessa pesquisa direcionada a um novo modelo de planejamento para o mercado de gás natural.

\subsection{Comparativo entre as projeções de oferta e demanda do PEMAT 2022 e outros estudos}

\subsubsection{Projeções de oferta}

As projeções norteiam o presente, já que é a partir da conjetura do futuro que planejamos nossas ações. Diferentes projeções para o mercado brasileiro de gás natural

\footnotetext{
${ }^{44} \mathrm{O}$ trabalho apresentado por Croso e Moutinho dos Santos (2014) foi a primeiro resultado do plano de pesquisa da autora, com foco no PEMAT e em seus impactos sobre o futuro mercado de gás natural no Brasil. O trabalho foi premiado pela Comissão Científica do Evento, sendo, assim, selecionado para ser publicado na Revista Brasileira de Energia (ainda no prelo).
} 
foram consideradas neste estudo. As perspectivas de aumento da oferta de gás natural associado ao desenvolvimento dos recursos naturais das camadas rochosas do pré-sal estão em todas as projeções.

\subsubsection{International Energy Outlook 2013 - EIA}

A Administradora de Informação da Energia dos Estados Unidos (U.S. Energy Information Administration - EIA) prevê no seu World Energy Outlook 2013, um crescimento da oferta de gás natural entre 2010 e 2040, a uma taxa anual média de 6,3\%, passando de 11,3 para 79,3 bilhões de metros cúbicos ao longo do período. Apenas $21 \%$ do crescimento no período refere-se a explorações não convencionais de gás natural; a maior parte está associada à produção nos campos do pré-sal. Com este crescimento, em 2040, o Brasil passa a responder por 27\% da produção regional (incluindo Américas do Sul e Central).

\subsubsection{World Energy Outlook 2013 - IEA}

A Agência Internacional de Energia (International Energy Agency) no seu World Energy Outlook 2013 fez um longo estudo sobre o setor energético brasileiro. As projeções feitas para um cenário de referência mostram altas taxas de crescimento na oferta de gás natural, a produção brasileira passa de 18 bilhões de metros cúbicos em 2012 para 38 bilhões em 2020 e 92 bilhões em 2035.

Como mostra a Figura 4.1, nas projeções da IEA, o crescimento da produção de gás em áreas tradicionais, como a Bacia de Campos, será modesto até 2020 e depois declinará; expansões robustas virão de novas fronteiras produtivas, principalmente na Bacia de Santos e em outras zonas de produção offshore, entre elas a produção no Espírito Santo, e onshore, as quais tornam-se mais significativas a partir de $2025^{45}$.

\footnotetext{
${ }^{45}$ Nas projeções da IEA, a produção onshore também apresenta um grande crescimento, partindo de 3 bilhões de metros cúbicos em 2010, e chegando a 8 bilhões, em 2020, e a 20 bilhões de metros cúbicos em 2035. Campos como os de Tucano e Recôncavo, na Bahia, que estão em produção há quase 50 anos continuam produtivos, assim como a bacia de Solimões que responde hoje por cerca da metade da produção nacional onshore. As bacias do Parnaíba, que participaram da $11^{\mathrm{a}}$ rodada de leilões, começaram a produzir comercialmente no início de 2013 e devem ser responder por uma grande parte da produção onshore, ainda são previstas menores, mas significativas, produções nas bacias de São Francisco e do Paraná.
} 


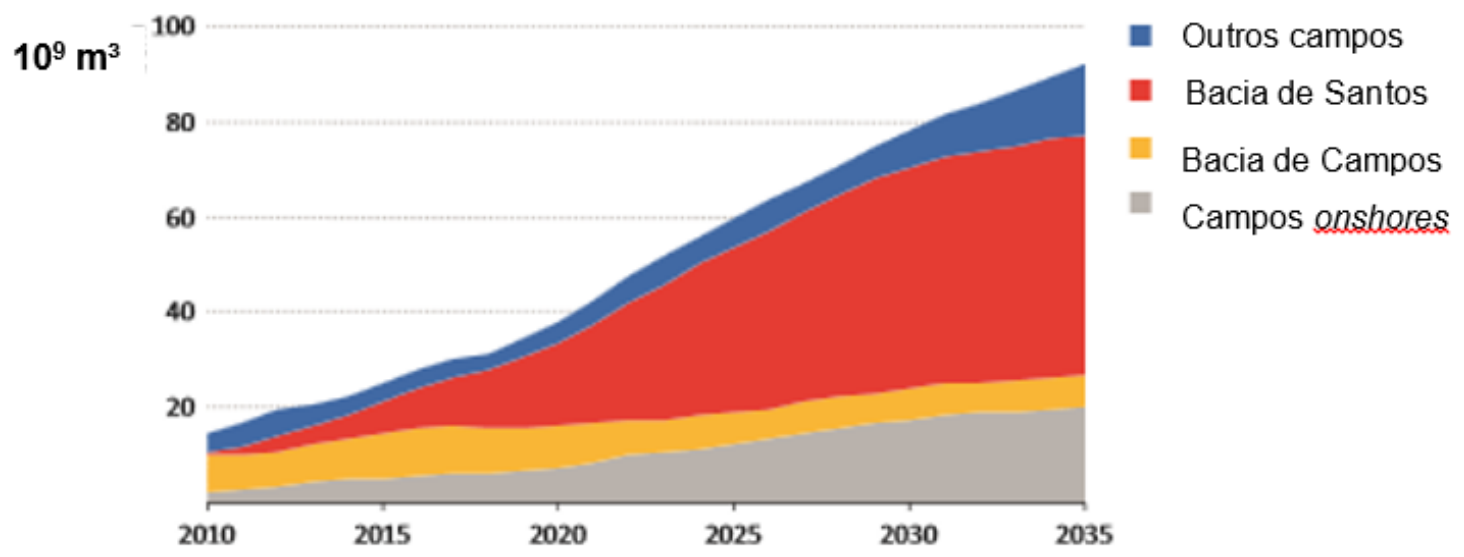

Nota: As projeções não contabilizam o gás queimado em tocha nas áreas de produção (flaire), ventilado ou re-injetade, mas inclui o gás consumido nos processos de produção.

\section{Figura 4.1 - Projeção para a produção de gás natural brasileira no cenário de referência}

Fonte: World Outlook of Energy (IEA, 2013)

A Agência Internacional de Energia também enfatiza que a presença de gás associado nas produções offshore é um problema para o Brasil, principalmente pela ausência de mercados cativos para o gás e a incipiência da infraestrutura de transporte, insuficiente para se escoar o excedente de gás que não pode ser consumido nas plataformas de produção. De acordo com a IEA (2013), o país necessita expandir a infraestrutura de dutos, ou alguma solução alternativa, que pode ser ainda mais dispendiosa, como a utilização de Floating Liquefied Gas Natural (FLGN) ${ }^{46}$.

\subsubsection{Plano Decenal de Energia 2022 - EPE}

A projeção da oferta de gás natural do Plano Decenal de Energia 2022, também produzido pela Empresa de Estudos Energéticos (EPE, 2013), é apresentada na Tabela 4.1. O gráfico da Figura 4.2 é a representação da projeção da produção bruta de gás natural no período entre 2014 e 2022.

\footnotetext{
${ }^{46}$ Navios que permitem liquefazer o gás natural em alto-mar, propiciando grande flexibilidade para eventual exportação do gás, principalmente se o mercado doméstico não estiver desenvolvido.
} 
Tabela 4.1 - Projeção da oferta potencial máxima de gás natural

\begin{tabular}{cccccccccc} 
& 2014 & 2015 & 2016 & 2017 & 2018 & 2019 & 2020 & 2021 & 2022 \\
\hline \hline $\begin{array}{c}\text { Produção } \\
\text { líquida }\end{array}$ & 24486 & 25062 & 27991 & 32104 & 38564 & 43926 & 50261 & 54158 & 54673 \\
\hline Importação & 25915 & 25915 & 25915 & 25915 & 25915 & 25915 & 25915 & 25915 & 25915 \\
\hline Total & 50401 & 50977 & 53906 & 58019 & 64479 & 69841 & 76176 & 80073 & 80588 \\
\hline
\end{tabular}

Fonte: PDE 2022 (EPE, 2013)

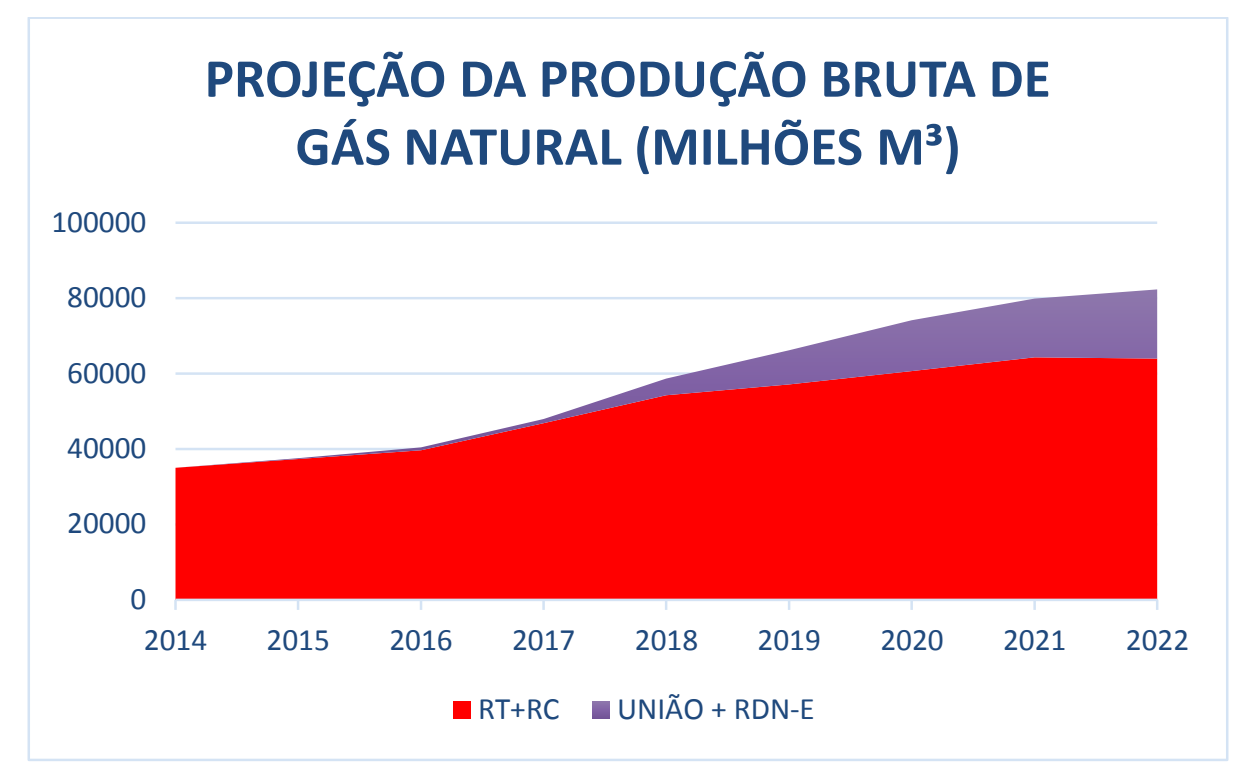

Figura 4.2 - Produção bruta de gás natural

Fonte: PDE 2022 (EPE, 2013)

A maior produção a ser produzida no decênio é de gás associado (GA), a produção de gás não associado também deverá ser muito significativa, assim como no final do período a contribuição dos recursos não descobertos $(\mathrm{RDN}-\mathrm{E})$ e de áreas de concessão da união descobertas e não descobertas (UNIÃO).

\subsubsection{PEMAT 2022 - EPE}

Assim como os demais estudos o PEMAT 2022 também projeta crescimentos significativos na oferta, principalmente na produção de gás associado. A Tabela 4.2 apresenta as projeções de oferta calculadas no estudo. Esta oferta corresponde à produção líquida, deduzida a absorção em unidades de processamento (UPGNs) e adicionada a capacidade de importação. 
Tabela 4.2 - Projeção da oferta de gás natural no período entre 2014 e 2022 (milhões de $\mathbf{m}^{3}$ )

\begin{tabular}{|c|c|c|c|c|c|c|c|c|c|}
\hline & 2014 & 2015 & 2016 & 2017 & 2018 & 2019 & 2020 & 2021 & 2022 \\
\hline $\begin{array}{l}\text { Produção Líquida } \\
\text { Potencial }\end{array}$ & 24492 & 25076 & 27996 & 32120 & 38581 & 43910 & 50261 & 54166 & 54677 \\
\hline Não disponível* (-) & 2190 & 2555 & 2628 & 3468 & 3650 & 3687 & 3687 & 3650 & 3395 \\
\hline Absorção ** (-) & 1241 & 1168 & 1314 & 1533 & 1862 & 2811 & 2811 & 3139 & 3285 \\
\hline Importação & 25915 & 25915 & 25915 & 25915 & 25915 & 25915 & 25915 & 25915 & 25915 \\
\hline Gasoduto & 10950 & 10950 & 10950 & 10950 & 10950 & 10950 & 10950 & 10950 & 10950 \\
\hline GNL & 14965 & 14965 & 14965 & 14965 & 14965 & 14965 & 14965 & 14965 & 14965 \\
\hline Oferta Potencial & 46976 & 47268 & 49969 & 53035 & 58984 & 63328 & 69679 & 73292 & 73913 \\
\hline
\end{tabular}

Notas: * Referem-se aos volumes de produção líquida potencial não disponibilizados para as UPGNs como, por exemplo, venda direta de gás não especificado (UTE "na boca do poço") e transferências operacionais para outras unidades produtivas.

** Absorção considera premissa de processamento integral da produção líquida potencial disponível para UPGN.

Fonte: PEMAT 2022 (EPE, 2014)

\subsubsection{PROJEÇÕES DE DEMANDA}

O otimismo em relação às projeções de oferta, são constatados também nas previsões de demanda. A disponibilidade do insumo possibilita expansões em variados setores da economia brasileira, desde a geração termelétrica, até o uso em indústrias para aumentar a eficiência e a produtividade, ou mesmo como matéria-prima.

\subsubsection{International Energy Outlook 2013 - EIA}

A Administradora de Informação da Energia dos Estados Unidos (U.S. Energy Information Administration - EIA) prevê no seu World Energy Outlook 2013, um crescimento anual médio no consumo de gás natural no Brasil, de 3,9\%, entre 2010 e 2040, ou um total de 54 milhões de metros cúbicos, que é próximo à metade de todo o crescimento na demanda, cerca de 113 milhões de metros cúbicos, previsto para a América Central e do Sul. 


\subsubsection{World Energy Outlook 2013 - IEA}

Em seu estudo a Agencia Internacional de Energia aponta projeções para o mercado de gás brasileiro ainda apresentam um alto grau de incertezas, porque em relação a outros países o Brasil apresenta um baixo consumo de gás. Para o período entre 2011 e 2035 o estudo aponta uma taxa de crescimento anual de 5,2\%, passando de 30 bilhões de metros cúbicos em 2011 para 90 bilhões de metros cúbicos em 2035.

\subsubsection{Plano Decenal de Energia 2022 - EPE}

As projeções de demanda do Plano Decenal de Energia 2022 são resumidas na . A taxa anual média de crescimento para o período entre 2013 e 2017 é de 7,0\%, e no período entre 2018 e 2022 é de 4,4\%.

Tabela 4.3 - Projeções de demanda de gás natural (milhões de m³)

\begin{tabular}{lccc} 
& 2013 & 2017 & 2022 \\
\hline \hline Demanda Total Esperada & 27813 & 39603 & 50699 \\
\hline Demanda Máxima & 41391 & 55772 & 67416 \\
\hline
\end{tabular}

Fonte: EPE, 2013

\subsubsection{PEMAT 2022 - EPE}

No estudo do PEMAT 2022 a projeção da demanda potencial de gás natural no horizonte de 2013 a 2022 é constituída através da análise das informações recebidas das distribuidoras de gás natural. A Tabela 4.4 apresenta os resultados da demanda potencial calculada no PEMAT 2022, a partir das informações apresentadas pelas distribuidoras locais com correções de viabilidade econômica ${ }^{47}$

\footnotetext{
${ }^{47}$ A metodologia utilizada pela EPE para as projeções de demanda de gás natural apresentadas no PEMAT 2022, foi explicitada anteriormente. Para estas projeções diversas análises de ordem econômicas foram feitas, com o objetivo de que o estudo contemplasse projetos que fossem economicamente atrativos, por exemplo, para que houvesse a penetração do gás natural em processos já existentes a EPE considerou o deslocamento de outros insumos energéticos, e para tanto o preço da tarifa cobrada do consumidor deveria ser igual ou menor do que o preço do óleo diesel.
} 
Tabela 4.4 - Demanda potencial não termelétrica de gás natural (milhões de $\mathrm{m}^{3} /$ dia)

\begin{tabular}{cccc} 
Região & 2013 & 2017 & 2022 \\
\hline \hline Sudeste & 27504 & 37478 & 45161 \\
\hline Sul & 4603 & 12191 & 15551 \\
\hline Nordeste & 8124 & 13816 & 18706 \\
\hline Centro-Oeste & 420 & 3004 & 3889 \\
\hline Norte & - & 5200 & 6400 \\
\hline TOTAL & 40651 & 71689 & 89707 \\
\hline
\end{tabular}

Fonte: PEMAT 2022 (EPE, 2014)

As projeções de demanda no PEMAT 2022 representaram, frente ao plano decenal, valores subestimados, portanto a fim de corrigi-los, utilizando informações do ciclo anterior do PDE, foi projetada uma nova demanda não termelétrica para o período. A projeção de demanda total é obtida com a adição da parcela térmica. Os valores, para o sistema integrado, ou seja, excluindo-se a região norte, são apresentados na Tabela 4.5.

Tabela 4.5 - Demanda potencial de gás natural ( milhões de m³/dia)

\begin{tabular}{cccc} 
DEMANDA & 2013 & 2017 & 2022 \\
\hline \hline Demanda não termelétrica & 60,8 & 98,2 & 127,9 \\
\hline Demanda termelétrica & 41,3 & 46,3 & 52,5 \\
\hline Demanda total & 102,1 & 144,5 & 180,4 \\
\hline
\end{tabular}

Fonte: PEMAT 2022 (EPE, 2014)

\subsection{Análise Comparativa}

Os resultados da análise comparativa entre as projeções dos Outlooks de Energia 2013 da IEA e da EIA e do Plano Decenal de Energia 2022 com as projeções do PEMAT 2022 são ilustrados nos gráficos das Figura 4.3 e Figura 4.4.

O gráfico da Figura 4.3 ilustra os resultados da comparação das projeções de oferta de gás natural para o período que compreende o estudo do PEMAT 2022. Da mesma maneira foram traçadas comparações entre as projeções de demanda apresentadas nos estudos consultados. A Figura 4.4 ilustra essa comparação. 


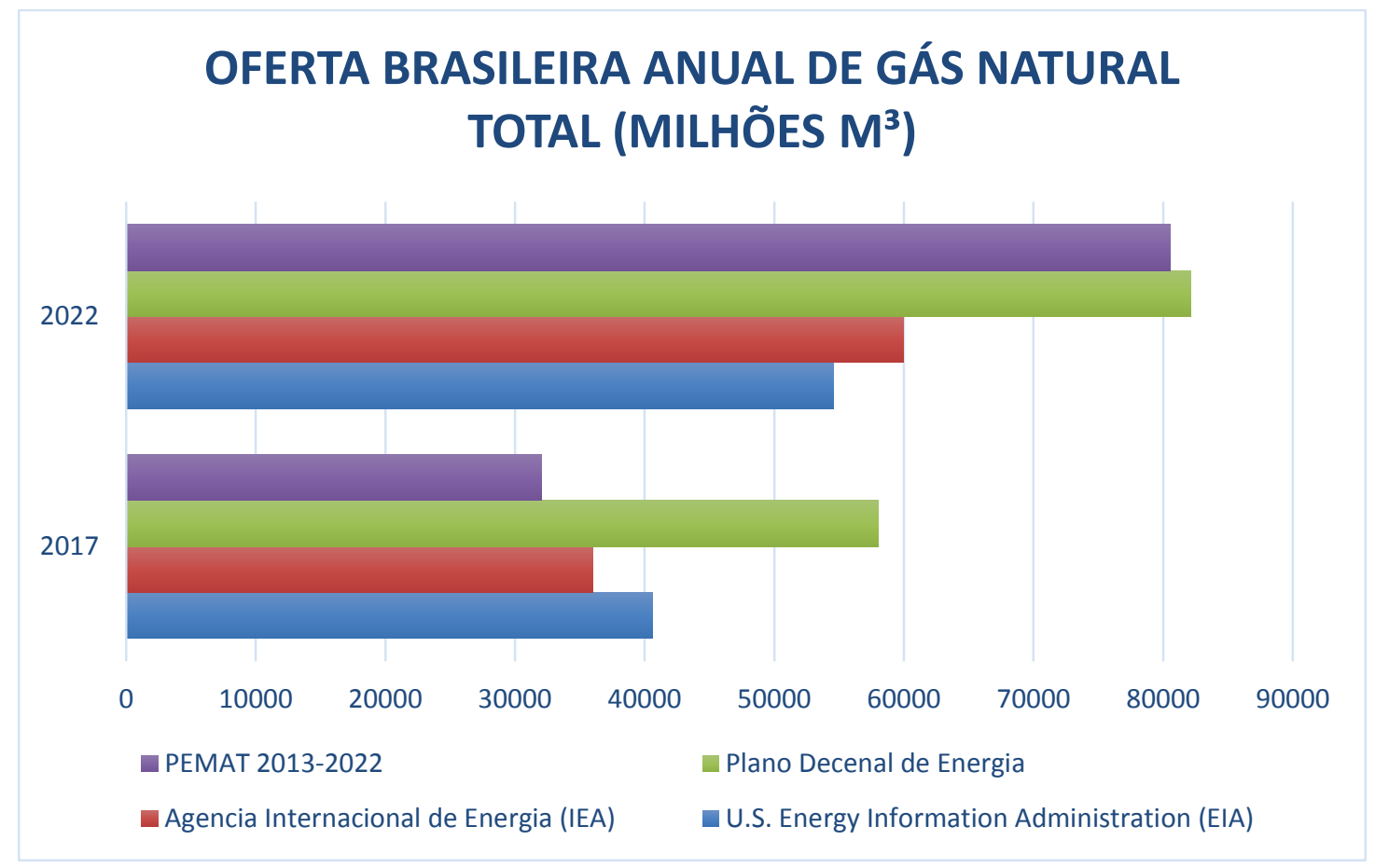

Figura 4.3 - Comparação entre as projeções de oferta de gás natural (2017 - 2022)

Fonte: Elaboração própria a partir de PEMAT 2022 (EPE, 2014), (IEA, 2013), (EIA, 2013) (EPE, 2013).

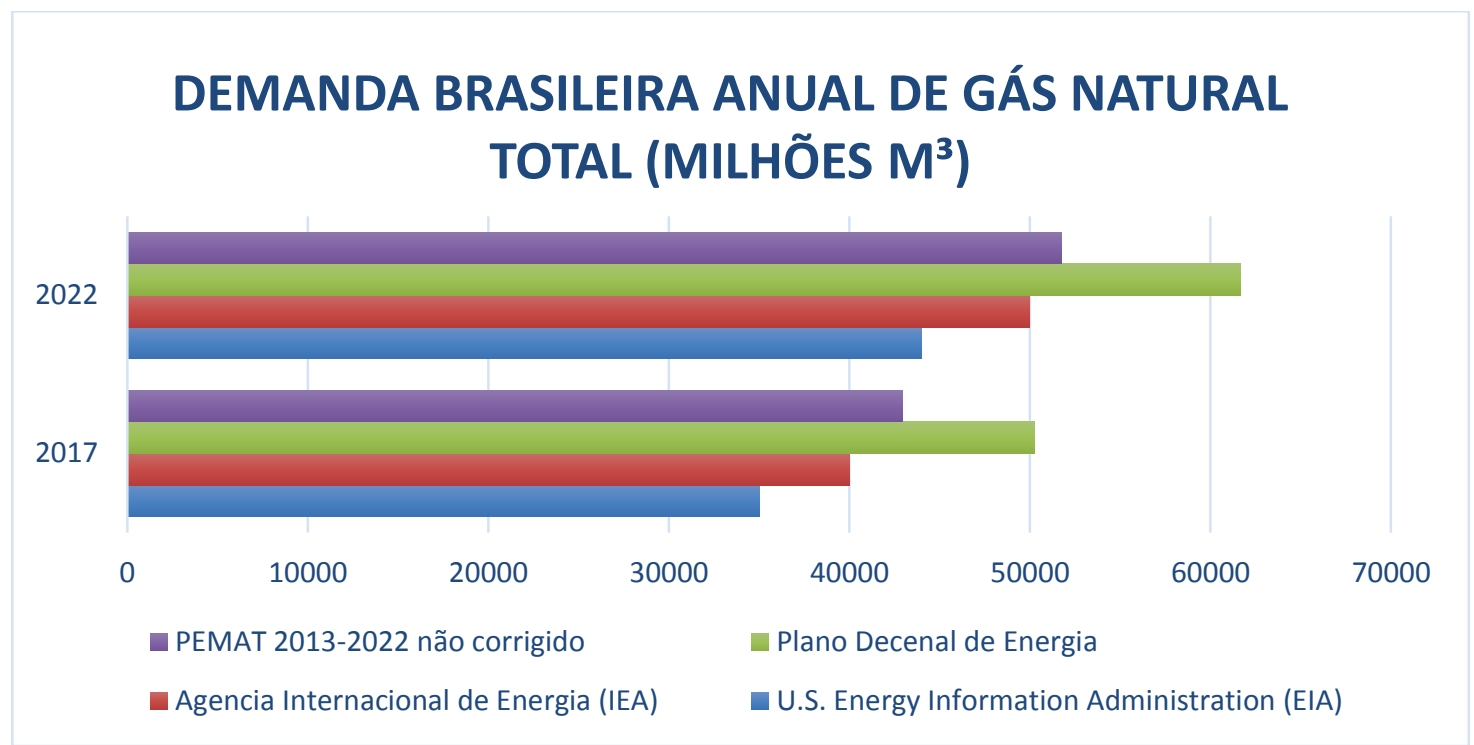

Figura 4.4 - Comparação entre as projeções de demanda de gás natural (20172022)

Fonte: Elaboração própria a partir de PEMAT 2022 (EPE, 2014), (IEA, 2013), (EIA, 2013) (EPE, 2013). 
A comparação entre as projeções de oferta dos diferentes estudos e as do PEMAT 2022 apresentou uma convergência, para o ano de 2017, o Plano Decenal de Energia 2022 apresentou um resultado mais otimista, para o ano de 2022 as projeções do PEMAT 2022 já se alinharam às do PDE 2022 foram mais otimistas que as dos estudos internacionais.

No caso da demanda as projeções do PEMAT no período também apresentaram otimismo em relação às projeções dos outros estudos, em ambos os períodos.

$\mathrm{Na}$ análise comparativa as projeções do PEMAT 2022, no geral, foram mais otimistas que as dos demais estudos, e apontaram crescimento substancial na oferta e demanda de gás natural, o que não é compatível com a conclusão do estudo, que considera a infraestrutura existente capaz de suportar o crescimento da oferta e demanda futuras, não havendo necessidade de ampliação no período analisado.

Estes resultados, que parecem incongruentes à primeira vista, refletem o posicionamento do setor energético. Ao se planejar um modelo de inserção de gás, com o crescimento da participação termelétrica com base no GNL, permite-se expansão limitada da malha. Trata-se de uma decisão deliberada do governo, visando sobretudo a garantia da oferta de energia elétrica. O PEMAT 2022 é um estudo determinativo, cuja metodologia na análise de viabilidade de novos projetos não permite antecipar necessidades futuras de capacidade.

Caso o modelo de inserção do gás no futuro seja o de ampliação do consumo industrial, o despacho deve ser na base e a expansão da malha é essencial. A ausência da malha de transporte inviabiliza, os projetos de autoprodutores onshore, porque compromete sobretudo a captação de recursos, já que o sucesso na produção não garante a comercialização deste gás. Assim as projeções de crescimento que se apoiaram em hipóteses de contribuição deste tipo de produção, principalmente após 2017, fragilizamse.

As projeções de demanda dos estudos analisados apresentam algumas divergências quanto à estratégia de penetração do gás no futuro mercado brasileiro. Comparando as projeções da demanda de gás natural do World Outlook of Energy 2013 da IEA por setor da economia (Figura 4.5), com as mesmas projeções do Plano Decenal de Energia 2022 (Figura 4.6) vemos como o modelo desejado de inserção do gás natural pode influenciar na expansão dos mercados e na diversificação do uso do gás natural. 


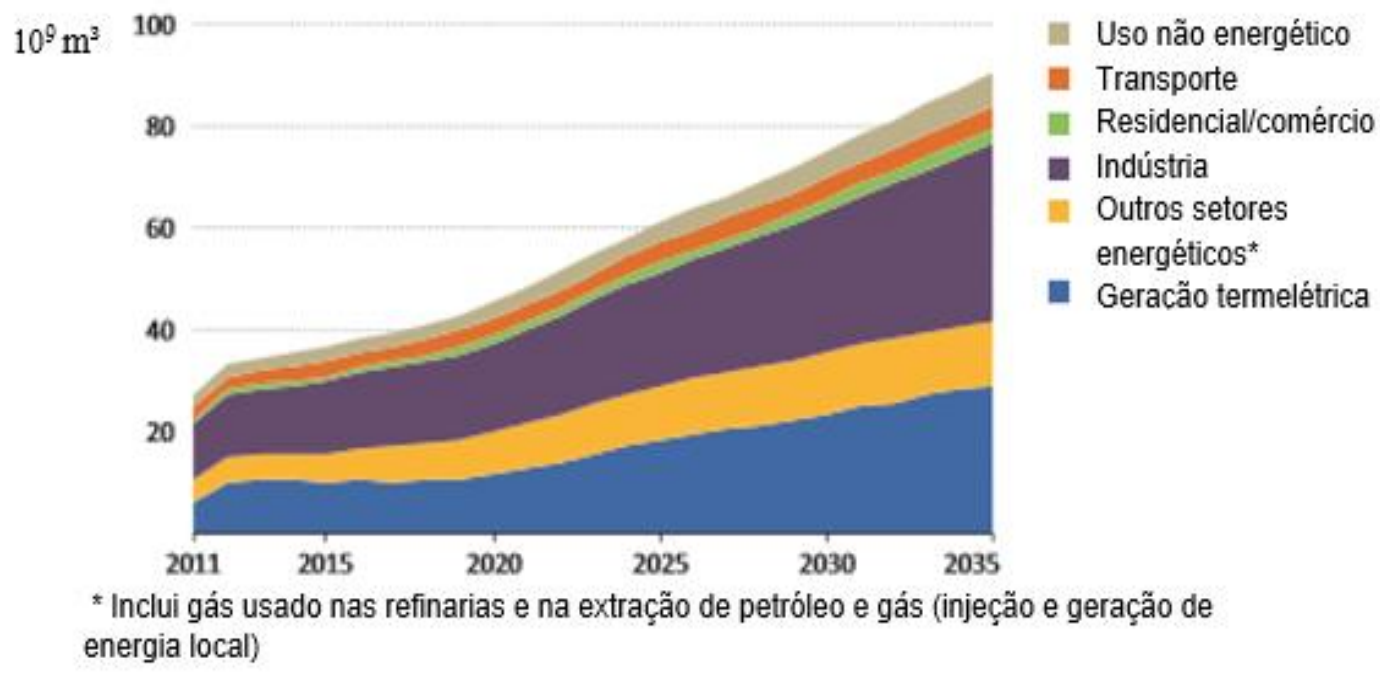

Figura 4.5 - Demanda brasileira de gás natural por setor no cenário de referência Fonte: World Outlook of Energy 2013(IEA, 2013)

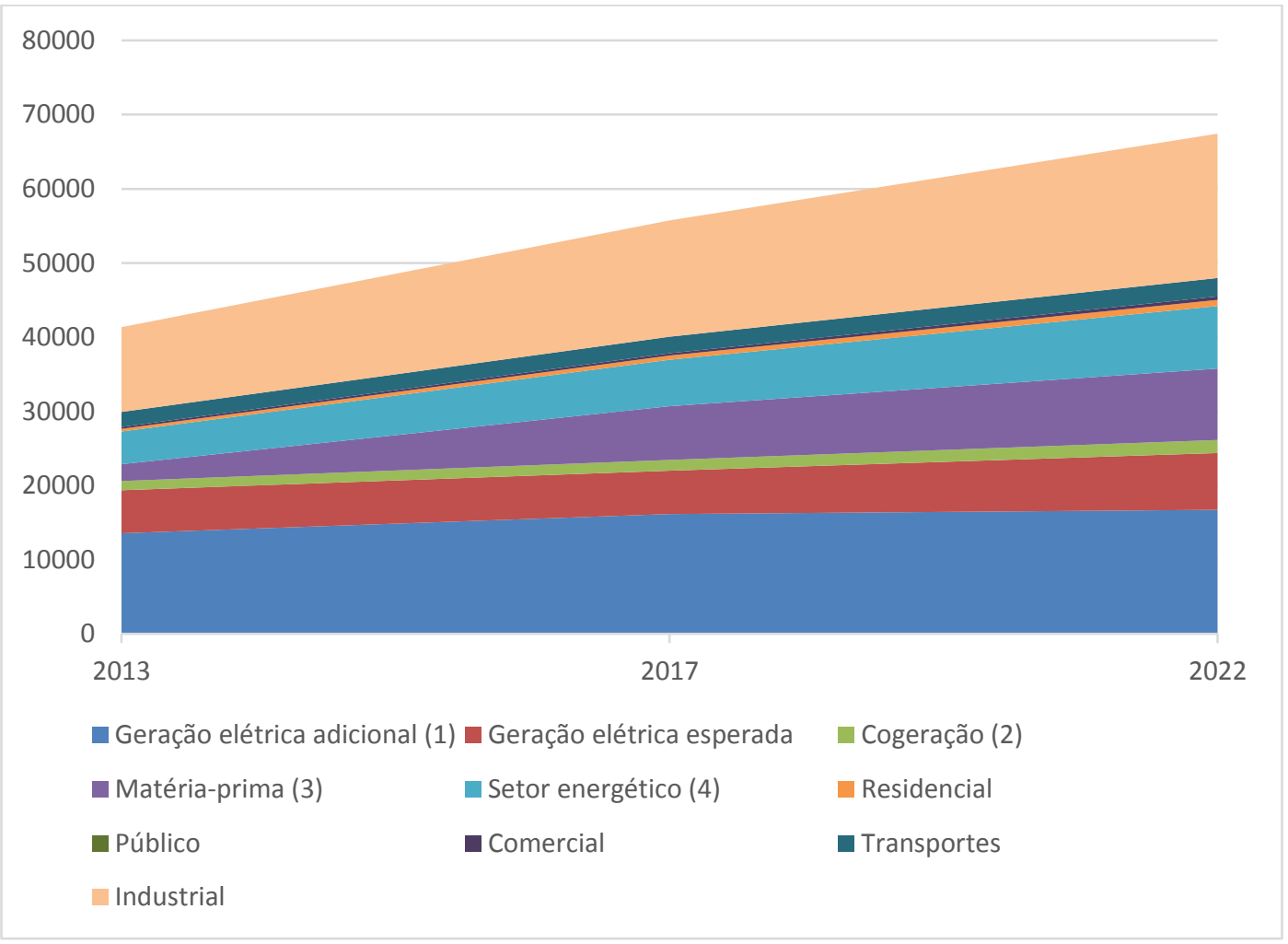

Figura 4.6 - Demanda brasileira de gás natural por setor no cenário de referência Fonte: PDE 2022 (EPE, 2013) 
Na Figura 4.6, é notável que a maior parcela da demanda encontra-se na geração elétrica adicional, pouco é o crescimento da demanda no setor industrial, já nas projeções da IEA, na Figura 4.5, o crescimento na demanda industrial é notável, além de apresentar crescimentos mais representativos nos demais setores.

A definição clara e estratégica do futuro mercado que se deseja desenvolver para o gás natural é que deve nortear as premissas e bases para o planejamento da expansão da malha de gasodutos no Brasil.

As diferenças entre as expectativas do crescimento da demanda por setores nos diferentes estudos tornam compreensíveis os resultados do PEMAT 2022, que são a representação de uma estratégia governamental visando garantir segurança energética diante dos ocasionais problemas do setor elétrico.

A segurança energética pode ser buscada de forma menos onerosa e mais planejada. A grande disponibilidade de gás natural fornece uma gama de possibilidades para o planejamento energético do país. Porque é uma fonte que não apresenta a intermitência da geração hidrelétrica, pode ter uma parcela da geração elétrica contratada de forma firme, além da possibilidade de ser disponibilizado diretamente em usos térmicos, principalmente nos setores de produção, onde pode deslocar a eletricidade, diminuindo o consumo de energia primária por uso final.

O custo da energia elétrica neste tipo de contrato, é mais que o dobro do preço da hidroeletricidade, já que a remuneração das concessões de usinas termoelétricas é dividida em dois componentes: parcela fixa e parcela variável. A parcela fixa é paga por período e serve para remunerar a concessionária por estar disponível para operar a qualquer momento. A segunda parcela, variável, busca ressarcir a concessionária por seus custos de operação e é paga apenas quando a concessionária está operante. Nesse caso, a remuneração é calculada com base na energia fornecida ( $\mathrm{R} \$ \mathrm{MWh})$. Essa parcela é definida previamente na concessão da usina (MARTITIS, 2012).

O acionamento térmico tem sido a solução do governo frente ao crescimento da demanda e às restrições na oferta de energia, em razão do nível baixo dos reservatórios das hidrelétricas.

Um dos principais objetivos da lei do gás é propiciar maior independência e transparência para incentivar a entrada de outros players no mercado de gás. No entanto da forma como foi instituída acabou tornando-se uma lei onde a interferência e poder do Estado estão mais presentes, de forma que novos projetos só podem ser licitados após a anuência do MME. 
Uma das premissas da EPE na produção do documento de ampliação das redes de transporte dutoviário foi que a ampliação deveria estar condicionada às potencialidade $\mathrm{e}$ necessidade de geração termelétrica. Não há nesta premissa o interesse governamental de inserir o gás natural na matriz energética como recurso energético disponível para a sociedade, estas premissas são deliberadas e apoiadas num modelo de consumo de energia instituído em períodos anteriores quando a oferta de energia elétrica era abundante e a dependência externa de combustíveis fósseis constituía um ônus e um fator de risco diante das incertezas do preço do petróleo.

Hoje, a situação brasileira é diversa, ainda com uma matriz renovável a intermitência destas fontes torna esta matriz muito dependente de condições climáticas, em situações adversas a solução é apoiar-se em um sistema de backup, no caso do brasileiro, a geração termelétrica. Este modelo faz com que as condições de oferta de gás natural estejam muito comprometidas com as flutuações do setor elétrico.

A definição clara e estratégica do futuro mercado que se deseja desenvolver para o gás natural é que deve nortear as premissas e bases para o planejamento da expansão da malha de gasodutos no Brasil.

Na comparação entre a Figura 4.5 e a Figura 4.6, fica evidente que as diferenças entre as expectativas do crescimento da demanda, por setor, nos diferentes estudos, torna compreensível os resultados do PEMAT 2022, que são a representação de uma estratégia governamental visando garantir segurança energética diante dos ocasionais problemas do setor elétrico.

Os resultados do PEMAT 2022 apontam para a manutenção deste quadro, onde ao invés de promover a difusão do gás em atividades que propiciem maior eficiência, a oferta de gás fica comprometida por um modesto aumento na infraestrutura, e em diversos pontos do estudo ressalta-se a opção do produtor em dar outra destinação ao gás natural, do que o fornecimento deste insumo como uma opção energética para a sociedade.

Ao se planejar um modelo de inserção de gás, com o crescimento da participação termelétrica com base no GNL, permite-se expansão limitada da malha. Trata-se de uma decisão deliberada do governo, visando sobretudo a garantia da oferta de energia elétrica. O PEMAT 2022 é um estudo determinativo, cuja metodologia na análise de viabilidade de novos projetos não permite antecipar necessidades futuras de capacidade. 


\subsection{Considerações finais sobre oferta e demanda}

Considerando a oferta, como apresentado no Capítulo 3, para a análise de viabilidade de projetos de construção ou expansão dos gasodutos, um dos fatores de maior relevância foi a disponibilidade de recursos. Na Figura 3.12 é notável que as projeções de oferta feitas pela EPE no PEMAT 2022 apoiam-se sobretudo em Recursos Contingentes (RC) e Recursos Não Descobertos (RND) (EPE, 2014).

Estas projeções alimentam o balanço de oferta e demanda de gás natural, realizado nas simulações fluído-termo-hidráulica que foram decisivas na definição de não viabilidade das alternativas de gasodutos estudadas. O resultado destas simulações foi apresentado na Tabela 3.14 - Avaliação das alternativas identificadas para aprofundamento nos estudos do PEMAT 2022 pelos critérios de balanço de oferta e demnda e tarifa de transporte - EVTE simplificadoErro! Fonte de referência não encontrada. (EPE, 2014).

As projeções de crescimento estimadas pela EPE são oficiais, e direcionam o planejamento do MME, mas no caso do PEMAT 2022, alternativas que seriam apoiadas nestas projeções não foram levadas à licitação porque a própria equipe considerou vulneráveis ofertas apoiadas em RC e RND.

\subsubsection{Oferta de gás natural e desenvolvimento de malhas}

Países que buscaram através de diferentes estratégias desenvolver suas malhas de gasodutos não o fizeram porque havia um excedente de gás natural. Em sua maioria tratavam-se de países importadores do recurso, o próprio Estados Unidos era um significativo importador de gás natural e, apesar de ostentar a bandeira da segurança energética, jamais identificou a autossuficiência como primordial.

Na Figura 4.7, é apresentada a malha de gasodutos na Europa, onde o gás natural desempenha um papel significativo nas matrizes energéticas de diversos países, e nem sequer há produção de gás natural. A Espanha é um exemplo desta realidade com quase $100 \%$ do gás natural importado este insumo corresponde a aproximadamente $22 \%$ de sua matriz energética. Em relação à matriz energética europeia o gás natural corresponde $23 \%$ (EUROSTAT, 2014). 


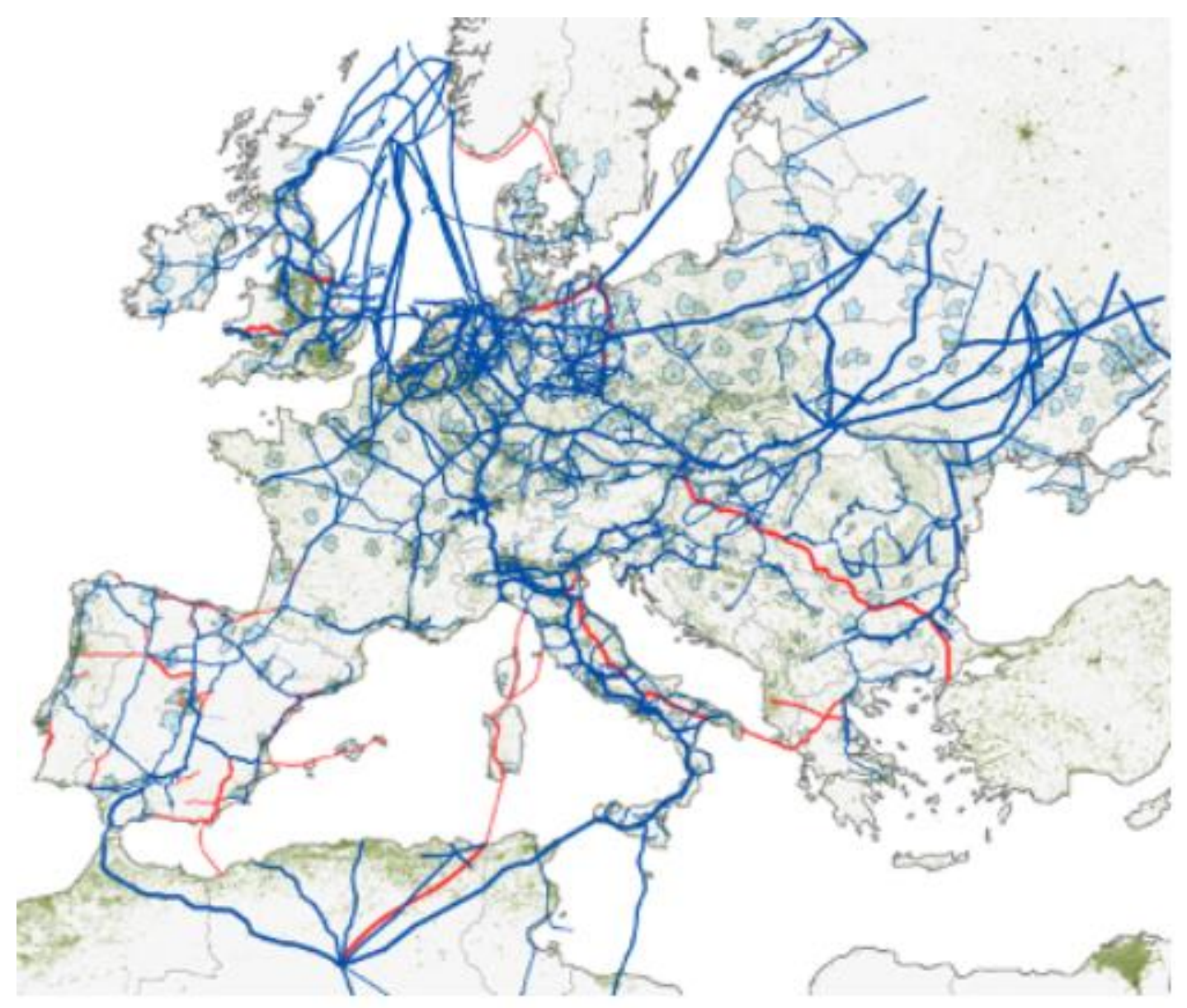

Figura 4.7 - Gasodutos na Europa

Fonte: http://arxiv.org/pdf/1311.7348v1.pdf

Mesmo no Brasil, o passo mais significativo para a criação de uma malha estruturante de gasodutos foi a construção do GASBOL, neste projeto em nenhum momento foram feitas análises de demanda e oferta potenciais, tratou-se de um esforço para diversificar a matriz energética, e o mercado brasileiro demorou anos para criar e consolidar a demanda de gás natural. Outros projetos no setor de energia também partiram do conceito da lei dos mercados (ou da Lei de Say), cujo pressuposto é que a oferta de um bem desejável, como um insumo energético, gerará sua própria demanda.

\subsubsection{A autossuficiência de gás natural}

A autossuficiência de gás natural não é necessária para os investimentos em malhas estruturantes de gasodutos porque, embora a interdependência energética crie, em determinados episódios políticos, aumento na percepção de risco regulatório e inseguridade de suprimentos, os contratos de gás, como explicado anteriormente, seguem 
boas práticas internacionais de mercantilização e costumam ser cumpridos, mesmo em situações extremas onde possam sofrer bruscas alterações o fornecimento de gás raramente é afetado ${ }^{48}$.

As projeções de oferta e demanda utilizadas na avaliação dos projetos, é altamente influenciada pela malha e pela perspectiva ou não de ampliação desta, porque muitos investimentos de produtores independentes só se viabilizam com a garantia de que uma bem sucedida produção possa ser escoada. Resultados apoiaram-se em projeções que, de certa maneira, contavam com a ampliação da malha para realizar-se.

A utilização de planejamentos de mínimo custo tem sido buscada como forma mais adequada à ampliação a oferta de recursos, no entanto, a adoção em parte desta metodologia, sem considerar a necessidade de se educar e adequar a demanda faz com que esta se torne incompleta, e necessite de escolhas onde o posicionamento ideológico e político do MME possa ser mais determinante do que qualquer etapa da metodologia adotada.

Programas de planejamento de mínimo custo devem observar na avaliação de potencial de penetração de um recurso diversos critérios como: preço da eletricidade, custos dos serviços energéticos, condições de financiamento, redução de riscos, tecnologia e combustíveis diversos, aspectos ambientais e desenvolvimento econômico.

O conceito de eficiência energética, é primordial para um planejamento de mínimo custo, porque supõe-se a racionalização da demanda, e, da mesma forma, a avaliação do potencial de penetração com base em preço dos energético é tendenciosa uma vez que decisões políticas, taxas e impostos influenciam estes valores. Desta forma a discussão da modicidade de preços ao consumidor do gás natural e dos demais energéticos deveria contemplar programas de administração da carga e eficiência, retenção nas ações de mercado, promoção de conservação, projetos alternativos, novas modalidades tarifárias, qualidade de energia e racionalidade do consumo.

\footnotetext{
${ }^{48} \mathrm{O}$ ano de 2013 foi marcado por insegurança no mercado de energia europeu por questões políticas envolvendo a Ucrânia, país onde ocorre a conexão de diversos gasodutos e a Rússia, o principal fornecedor de gás para a Europa. No entanto, o fornecimento de gás foi mantido e em outubro de 2014 foi firmado um acordo político garantindo o fornecimento durante o inverno destes países, ou seja, até março de 2015.
} 


\subsection{Crítica do modelo de inserção do gás existente no PEMAT 2022}

A análise do balanço de oferta e demanda realizada no PEMAT 2022 adotou uma série de considerações, como apresentado no item 3.5.3, nos quais estava presente a priorização da demanda termelétrica. Todavia, como visto no capítulo 2, a Lei do Gás não aponta usos prioritários para o gás natural, deixando tal discricionariedade para o gestor público no momento do planjemaneto setorial. Nesse sentido, defende-se nesse trabalho que como parte de um planejamento maior, o PEMAT poderia ter seu foco na expansão da malha e na massificação do uso do gás.

Embora, que no atual contexto do setor elétrico brasileiro, seja inegável a necessidade da geração termelétrica, o modelo de inserção do gás natural na matriz energética baseado em termelétricas abastecidas com GNL não difunde o uso do gás natural em outros setores, nem propicia a expansão da malha.

No que diz respeito criação de incentivos para ampliação da infraestrutura, Gonzales (2014) recomenda a sinergia entre os leilões de energia nova e o planejamento de gás, como a regionalização dos leilões e proposições de um "mercado firme" de gás natural. Ainda, para Gonzales (2014) essa medida teria o bônus de garantir melhores preços de geração do que os apoiados em preços do GNL spot. Embora o autor reconheça que estas mudanças provocariam perda de flexibilidade (GONZALES, 2014).

A vantagem de se ter a mesma empresa de pesquisa e ministério coordenado o planejamento dos setores elétricos e de gás é a possibilidade de se planejar buscando principalmente a racionalidade da demanda. Neste ponto, o planejamento para o setor de gás foi falho porque não ampliou a oferta deste recurso onde possa encontrar suas demandas mais racionais, deslocando a eletricidade na geração de calor, por exemplo. Pelo contrário, evidencia-se a postura do MME em relação à destinação do gás natural: o crescimento da demanda termelétrica, do uso como matéria-prima, e em refinarias, em detrimento dos usos industrias, veiculares e residenciais.

Em sua tese de doutorado, Costa (2013) demonstrou que, em 2012, havia um potencial de redução de 20.890,3 GWh, apenas com substituição da eletrotermia em aquecimento direto e calor de processo pelo uso de gases combustíveis (GN e GLP) na indústria brasileira.

Outra vantagem encontrada no formato adotado de o MME planejar ambos os setores, é a facilidade de se realizar o planejamento contemplando a complementariedade 
de fontes, de acordo com a natureza de sua geração. A prioridade de acionamento de usinas para o melhor aproveitamento destes recursos, é mostrada na Figura 4.8.

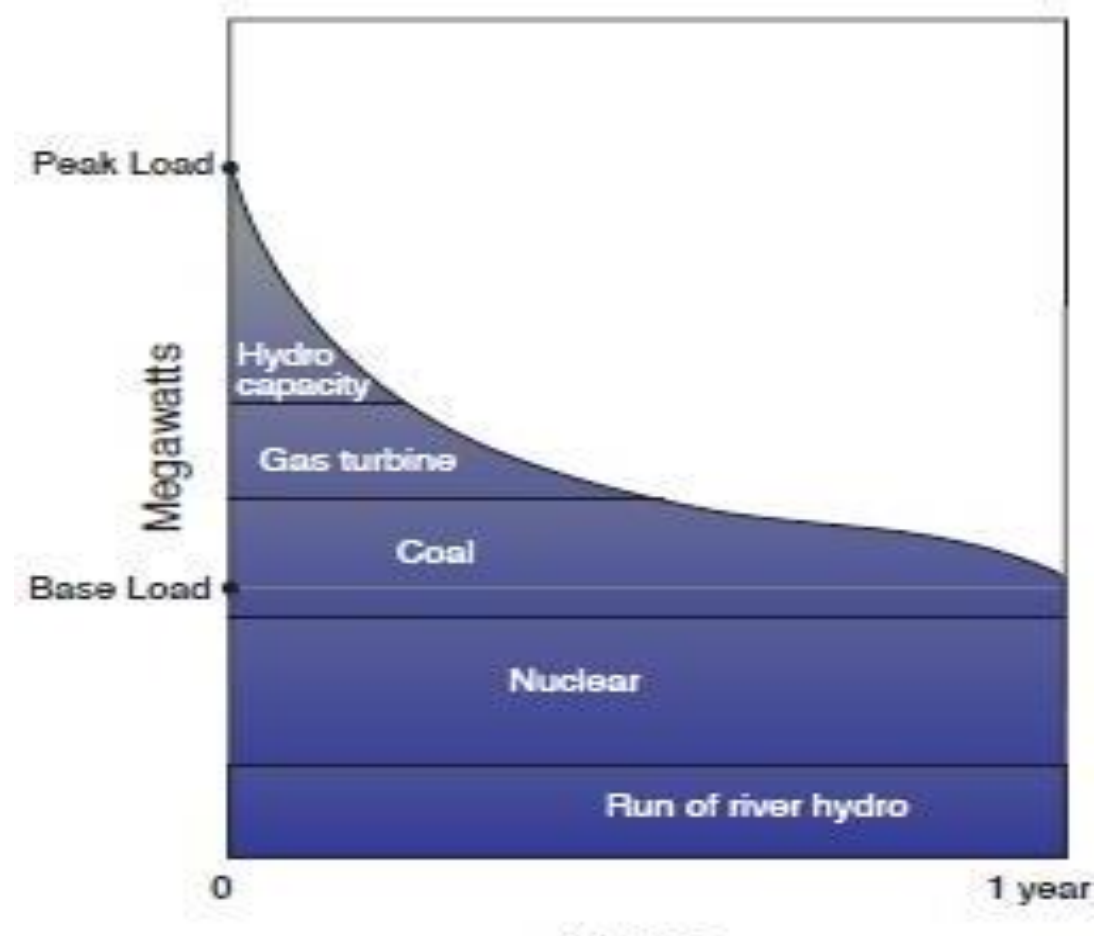

Hours

\section{Figura 4.8 - Ordem de mérito no despacho}

Fonte: Prof. Idlo Sauer (notas de aula, 2014)

Entretanto, a geração termelétrica no Brasil é contratada como adicional, backup da geração hidrelétrica, seja ela usina de fio d’água ou usina de reservatório. Nos últimos anos houve uma necessidade constante de acionamento térmico, por diversos fatores, onde se destacam condições hidrológicas desfavoráveis e consequências de medidas governamentais, dentre as quais destaca-se os efeitos decorrentes da edição da Medida Provisória (MP) 579/2012 e legislação subsequente, que na tentativa de ampliar o acesso 
à eletricidade, contribuiu para a diminuição de medidas de eficiência energética e o crescimento da intensidade energética, principalmente no setor de energia ${ }^{49,50}$.

Além de tratar da prorrogação das concessões, a referida MP 579 também reduziu a incidência de encargos setoriais na tarifa de eletricidade, foram eliminados os encargos Conta de Consumo de Combustíveis (CCC) e Reserva Geral de Reversão (RGR) e diminuído $75 \%$ da CDE, com o objetivo de possibilitar uma redução mais substancial do preço da eletricidade no Brasil ${ }^{51}$. A redução nas tarifas de energia elétrica tinha a finalidade de aumentar o acesso ao bem estar da energia, e incentivar a produção, mas esta redução, a priori, não parece fruto de um equilíbrio de mercado, e sim de uma determinação política.

\footnotetext{
${ }^{49} \mathrm{Em} 2012$ se encerravam contratos de fornecimento de energia estabelecidos entre empresas de geração e distribuidoras, decorrentes do primeiro leilão de energia do modelo criado por Dilma. Assim, estes leilões realizados em final de 2004 e em 2005 comercializaram 17.000 MWmed de energia assegurada, com preços muito baixos e que refletiam a conjuntura de mercado da época. Além do vencimento destes contratos, coincidiram o vencimento dos contratos de concessões de muitas usinas, entre elas muitas geradoras de "energia velha". Ou seja, as concessões de um conjunto de usinas de geração que totalizam $22 \mathrm{GW}$ de capacidade instalada ou $20 \%$ do parque de geração brasileiro, 69 mil Km de linhas de transmissão (67\% do total brasileiro) e 44 contratos de distribuição (35\% do total). Pela legislação original, ao final do prazo de concessão, os serviços retornariam à propriedade da União e seriam objeto de uma nova licitação. (Pioto, 2013). Igualmente, no âmbito das discussões e pressões de diversos setores sociais por modicidade dos preços e tarifas de energia elétrica nasceu a polêmica MP 579 de 11 de setembro de 2012, convertida na Lei 12.783/2012 que tinha como objetivo principal promover a modicidade tarifária, com o fim de ampliar o acesso ao bem da energia, e diminuir os custos de produção, aumentando assim a produtividade da indústria brasileira e a sua competitividade frente às indústrias estrangeiras. Antes de presidente da república, a economista Dilma Rousseff foi ministra de minas e energia e foi responsável por uma reformulação do setor elétrico, entre as principais mudanças estava a criação de uma empresa de planejamento. As distribuidoras de energia passaram a exercer exclusivamente a atividade de distribuição, ou seja, receber remuneração pelo serviço de disponibilização de ativos (capital) e operação e manutenção da rede e bilhetagem. Para as distribuidoras, os riscos associados ao preço do suprimento de energia foram mitigados e agora existe a obrigatoriedade de aquisição de $100 \%$ das suas necessidades energéticas, com cinco anos de antecedência em leilões organizados pelo regulador. $\mathrm{O}$ mercado regulado com tarifas definidas pela ANEEL foi, desta forma, separado do mercado livre. Medida Provisória 579 antecipou a revisão dos contratos de concessão de geração, distribuição e transmissão, com indenização dos bens reversíveis não amortizados.
}

${ }^{50} \mathrm{O}$ novo modelo pode ser considerado bem sucedido em vários aspectos, afastou riscos iminentes de novas crises de suprimento com investimentos em geração e conseguiu uma substancial redução do preço da energia por meio dos leilões de energia para as Distribuidoras. E porque houve uma significativa redução da população sem acesso à rede elétrica, com inclusão, até setembro de 2011, de 14,2 milhões de brasileiros com luz elétrica em suas moradias (GOVERNO DO BRASIL, 2011).

${ }^{51}$ Os preços elevados das tarifas de energia elétrica brasileira são influenciados pelos encargos e tributos, e especialmente dois destes encargos causavam grande contestação; a Reserva Geral de Reversão (RGR), que constituí um fundo indenizatório para uma eventual cassação de concessões e para indenização de ativos não amortizados ao final de um período de contrato de concessão e a Conta de Consumo de Combustíveis (CCC) deveria ser utilizado para subsidiar o custo de combustíveis em regiões do Brasil, ainda sem conexão ao sistema interligado. Este encargo foi revisto em 2009, com aumento de quase $100 \%$ e foi eliminado qualquer prazo para sua extinção. 
No entanto, em uma diretiva, este modelo fracassou, porque foi incapaz de reduzir os preços das tarifas de energia, que permaneceram muito influenciados por uma ampla carga tributária e por encargos setoriais, que em muitos casos vigoram desde muito tempo (SANTANA, 2012). Além do crescimento da geração elétrica a partir de usinas termoelétricas movidas a gás natural e com custo de operação mais caro comparativamente às usinas hidroelétricas.

Dessa maneira, salienta-se que o planejamento governamental dos setores elétrico e gasífero foi fruto de decisões políticas pontuais e que o PEMAT também é um reflexo de escolhas que priorizam a eletrotermia, aumento da intensidade energética e diminuição da eficiência energética.

Ao invés de um planejamento que enxergue a dimensão temporal além do mandato presidencial de quatro anos, o governo embarcou na fórmula mais simples para se reeleger, diminuir tarifas a curto prazo. No entanto, no início de 2015 , já se noticia aumentos na tarifa da eletricidade para consumidor final, o que já vinha ocorrendo desde meados de 2014 com o crescimento da geração termelétrica, que será abordada no tópico 4.6.

\subsection{Consumo de energia no Brasil: o crescimento da geração termelétrica a gás natural}

Avaliando o Balanço Energético Nacional de 2013, relativo ao ano de 2012, notase o aumento no consumo final de eletricidade, de 3,8\%, puxado pelas famílias e pelo setor de serviços, que foi atendido com aumento da geração térmica convencional, especialmente das usinas movidas a gás natural, cuja participação na matriz cresceu de 4,4\% para 7,9\%. Como decorrência houve aumento das perdas na transformação (o rendimento da planta térmica na conversão para eletricidade é bastante inferior ao da usina hidrelétrica) (EPE,2013). 


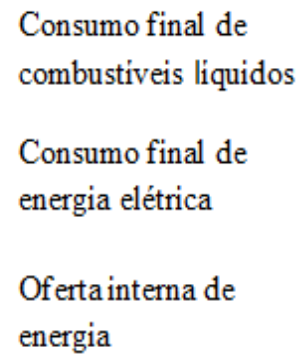

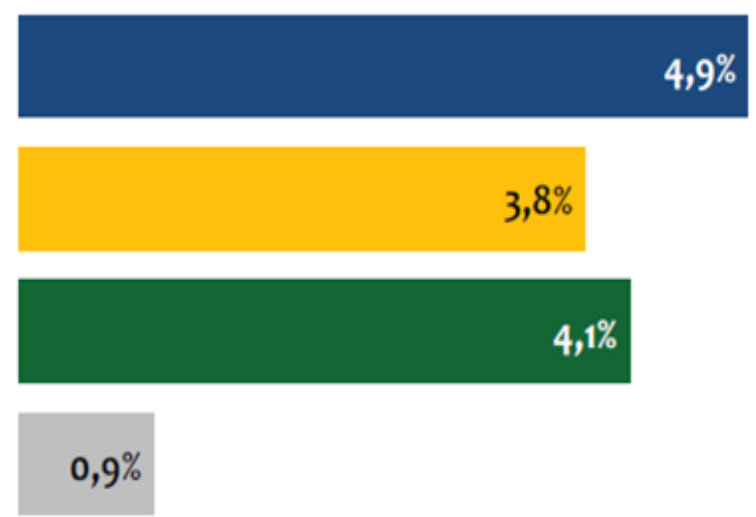

Nota: Combustiveis liquidos e eletricidade correspondem a cerca de $55 \%$ do consiono final de energia

Figura 4.9 - Crescimento do consumo energético 2012/2011

Fonte: (MME,2013)

De fato, segundo pesquisa da Associação Brasileira dos Grandes Consumidores Industriais de Energia e Consumidores Livres (Abrace), a redução de 7,5\% no custo da energia elétrica para a indústria foi insuficiente, $89 \%$ das empresas consultadas se disseram não estimuladas pela redução (Jornal Estado de Minas, 25/09/2013).

A Figura 4.10 apresenta as matrizes de geração elétrica brasileira dos anos de 2011 e 2013, ao comparar as mudanças pode-se perceber como os fatores do último ano, entre eles a medida provisória 579, modificaram a matriz brasileira. Por condições hidrológicas desfavoráveis a geração hidráulica diminuiu, enquanto o uso de gás natural e derivados de petróleo para a geração de eletricidade aumentou.

Um dos problemas da geração termelétrica é a eficiência das usinas, utilizando gás natural com o melhor uso da tecnologia, em ciclo combinado, a eficiência destas usinas pode chegar a 50\% (REIS, 2003). No entanto, como pode ser observado na tabela anterior, mesmo tendo se tornado mais eficientes no decorrer do tempo, a média de eficiência das termelétricas brasileiras é mais baixa, $41 \%$ em 2012, como pode ser observado na Tabela 4.6 (BEN,2013). 
BRASIL 2013

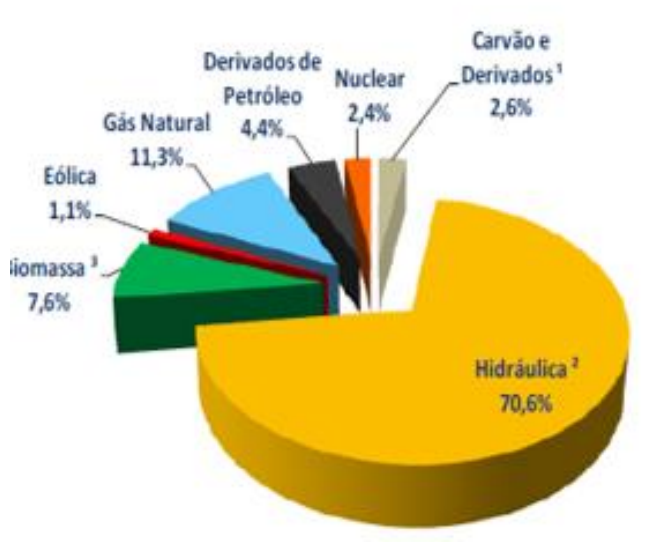

geração hidraulica² em 2013: 430,9 TWh geração total ${ }^{2} \mathrm{em}$ 2013: 609,9 TWh "Inclui gós de coqueria;

Inciui importação;

sInclui lenha, bagoço de cana, lixívia e outras recuperações.
BRASIL 2011

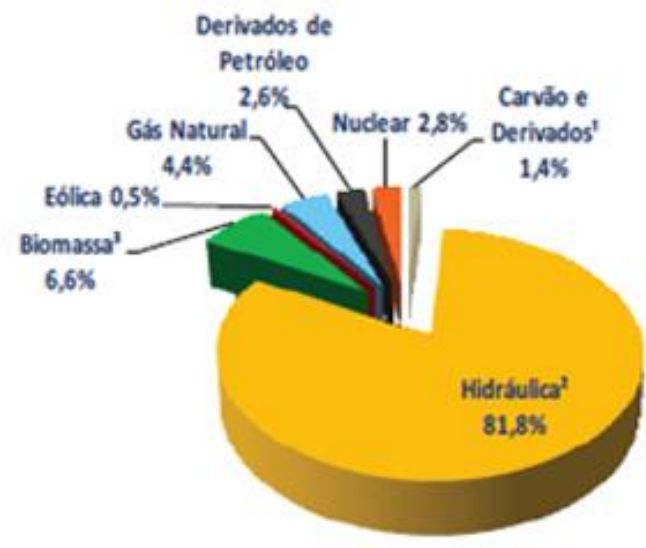

geração hidraulica² em 2011: 464,2 TWh geração total ${ }^{2}$ em 2011: 567,7 TWh

Figura 4.10 - Matriz de geração elétrica 2011/2013

Fonte: (MME,2013)

Outro ponto de preocupação é o custo da energia elétrica gerada em termelétricas, que é mais que o dobro do preço da hidroeletricidade, e a remuneração das concessões de usinas termoelétricas é dividida em dois componentes: parcela fixa e parcela variável. A parcela fixa é paga por período e serve para remunerar a concessionária por estar disponível para operar a qualquer momento. A segunda parcela, variável, busca ressarcir a concessionária por seus custos de operação e é paga apenas quando a concessionária está operante. Nesse caso, a remuneração é calculada com base na energia fornecida (R\$MWh). Essa parcela é definida previamente na concessão da usina (MARTITIS, 2012).

Um dos principais argumentos da modicidade tarifária foi o estímulo à produção. No entanto, a MP 579 contribuiu para a tendência à eletrificação, com o crescimento do consumo total de eletricidade no período, 2011 a 2012, sendo superior ao crescimento do consumo total de energia (ver Figura 4.11). Não se pode afirmar que isso ocorreu apenas em decorrência da MP 579, esta é uma tendência motivada em parte porque a sociedade brasileira tem experimentado avanços sociais e um maior número de pessoas têm utilizado a energia elétrica para proporcioná-las mais conforto e bem estar. 
Tabela 4.6 - Centrais elétricas de serviços públicos

\begin{tabular}{|c|c|c|c|c|c|c|c|c|c|c|c|}
\hline Identificação & 2004 & 2005 & 2006 & 2007 & 2008 & 2009 & 2010 & 2011 & 2012 & 2013 & unidade \\
\hline $\begin{array}{l}\text { consumo de } \\
\text { combustíves }\end{array}$ & -9756 & -9333 & -10257 & -9384 & -12837 & -8782 & -13237 & -11094 & -16992 & -24.086 & \\
\hline gás natural & -3025 & -2908 & -2577 & -2108 & -4565 & -1574 & -4818 & -2897 & -6700 & -11.575 & \\
\hline carvão vapor & -1724 & -1837 & -2050 & -1900 & -1748 & -1480 & -1721 & -1591 & -2180 & -3.566 & \\
\hline Lenha & 0 & 0 & -49 & 0 & 0 & 0 & -14 & -19 & -45 & -64 & \\
\hline óleo diesel & -1676 & -1670 & -1368 & -1155 & -1597 & -1361 & -1820 & -1696 & -2261 & -2.349 & \\
\hline $\begin{array}{c}\text { óleo } \\
\text { combustível }\end{array}$ & -286 & -417 & -606 & -951 & -1172 & -840 & -890 & -469 & -1053 & -2.016 & \\
\hline $\begin{array}{l}\text { urânio contido } \\
\text { no } \mathrm{UO}_{2}\end{array}$ & -3030 & -2482 & -3582 & -3213 & -3641 & -3377 & -3780 & -4081 & -4180 & -3.815 & $10^{3}$ Tep \\
\hline $\begin{array}{l}\text { Outras } \\
\text { renováveis }\end{array}$ & -15 & -19 & -35 & -57 & -113 & -151 & -193 & -290 & -520 & -625 & \\
\hline $\begin{array}{l}\text { Outras não } \\
\text { renováveis }\end{array}$ & 0 & 0 & 0 & 0 & 0 & 0 & 0 & -51 & -53 & -75 & \\
\hline $\begin{array}{l}\text { geração de } \\
\text { eletricidade }\end{array}$ & 30060 & 31239 & 32477 & 34229 & 35433 & 35187 & 38081 & 39106 & 40804 & 41.612 & \\
\hline $\begin{array}{l}\text { geração } \\
\text { hidráulica }\end{array}$ & 26538 & 27955 & 28875 & 30896 & 30469 & 31964 & 32904 & 34883 & 33960 & 31.729 & \\
\hline $\begin{array}{l}\text { geração } \\
\text { térmica }\end{array}$ & 3522 & 3285 & 1602 & 3333 & 4965 & 3223 & 5178 & 4223 & 6845 & 9.884 & \\
\hline $\begin{array}{l}\text { perdas na } \\
\text { geração } \\
\text { térmica }\end{array}$ & -6234 & -6048 & -6665 & -6051 & -7872 & -5559 & -8059 & -6871 & -10148 & -14.202 & \\
\hline $\begin{array}{l}\text { rendimento } \\
\text { médio- } \\
\text { térmicas }\end{array}$ & 36,1 & 35,2 & 35,1 & 35,5 & 38,7 & 36,7 & 39,1 & 38,1 & 40,3 & 41,0 & $\%$ \\
\hline
\end{tabular}

Fonte: (MME,2013)

O Plano Nacional de eficiência energética (PNEf) visa ações de diferentes naturezas que resultem em economia de energia para atender a demanda energética da sociedade por luz, calor, frio, acionamento, transporte e o uso em processos. Por estas ações entendem-se aperfeiçoamentos tecnológicos ao longo da cadeia energética, mas também podem ser resultados de melhores organizações, conservação e gestão energética. 


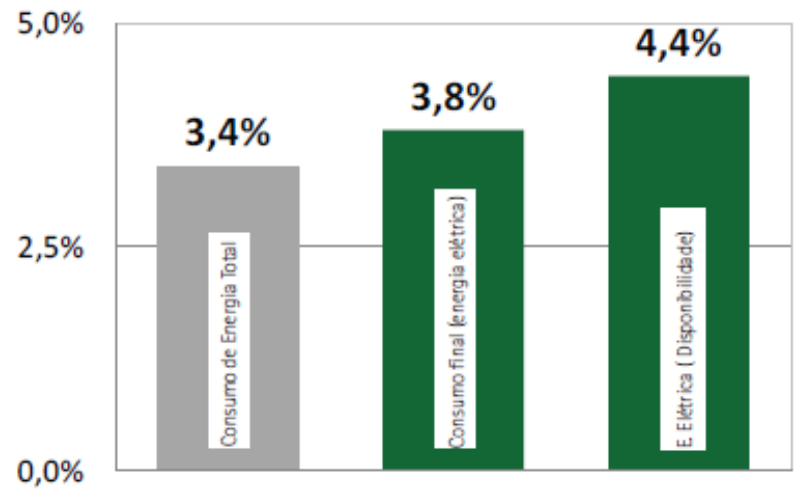

Figura 4.11 - Crescimento do consumo de energia

(MME,2013)

Segundo as diretrizes do Plano procuram-se considerar os ganhos com eficiência energética em duas parcelas, uma autônoma, que se dará de forma espontânea por parte do mercado, através da renovação dos equipamentos por outros mais modernos e da adoção de novas tecnologias mais eficientes. E outra, de maneira induzida, através de políticas públicas.

Os planejamentos também se baseiam nestas duas formas de aperfeiçoamento da eficiência energética do sistema, eles preveem a parcela de energia economizada, através de progressos tendenciais, ou seja, melhorias oriundas das necessidades e adaptações do mercado, sem a necessidade de intervenção de agentes públicos, nesta abordagem encontram-se as medidas de eficiência energética que viabilizam o potencial de mercado, que é definido como sendo uma parcela do potencial econômico na qual os consumidores possuem percepção de riscos menores para a execução de investimentos em projetos de redução de demanda e economia de custos.

Quando induzido por políticas públicas este progresso procura beneficiar medidas que são economicamente viáveis, mas que possuem uma pequena penetração no mercado consumidor, em razão de uma percepção de risco elevada, seja por questões comportamentais, técnicas ou econômicas.

Foi adotada como premissa básica a redução de $10 \%$ do consumo de energia elétrica no horizonte previsto no cenário B1 (consumo base) do PNE 2030 (Plano Nacional de Energia 2030). As projeções de demanda de energia se apoiam nas análises do contexto macroeconômico nacional e internacional, além de premissas sócio 
demográficas, perspectivas de expansão de atividades e modo de uso de energia nos diversos setores de consumo, bem como análise de autoprodução e eficiência energética.

Para o setor industrial a energia é vista como um fator de custo e não de resultados, o peso da energia é significativo no custo final dos produtos. Para atingir competitividade no mercado internacional a indústria brasileira deveria trabalhar com os mesmos níveis de eficiência energética. Neste contexto a tecnologia tem um papel fundamental, já que compõe um dos principais fatores de competição.

Investimentos em eficiência energética enfrentam resistências devido aos riscos que não conseguem ser bem mensurados pelo setor financeiro. Poucas linhas de financiamento trabalham com investimentos de projeto em eficiência energética, e as que o fazem exigem burocracia excessiva no processo de liberação do crédito.

Para o setor industrial os investimentos em eficiência energética concorrem com investimentos na produção que trazem receitas adicionais às empresas. Com exceção de indústrias eletro-intensivas os investimentos que melhoram o desempenho energético são preteridos, devido à predileção por investimentos que tragam um retorno a curto prazo e à ausência de uma cultura de gestão energética.

Esta ausência fica evidente ao observar a estrutura das indústrias, onde os sistemas térmicos muitas vezes não possuem o devido isolamento, que é a forma mais barata e elementar de propiciar maior eficiência energética. Assim como também não há aproveitamento dos potenciais; apenas um número reduzido de indústrias adotam soluções de utilidades com geração de eletricidade, e cogeração de frio e calor de processo.

Como soluções o PNEf apresenta em suas diretrizes uma série de medidas, entre elas a criação de mecanismos para a conscientização, divulgação e informação das empresas a fim de amadurecer o conceito de que o aumento da eficiência promove maior competitividade.

No entanto, recentemente nenhuma medida teve maior impacto, no sentido de sinalizar o comportamento do consumidor de energia, do que a MP579, que, de certa forma, apoiou a ideia da energia como um custo e não incentivou a oportunidade de atingir maior competitividade a partir do aumento da eficiência. A MP 579 contribuiu para a eletrificação dos processos, onde poderiam utilizar outras fontes que propiciassem melhor eficiência do sistema energético como um todo.

A Figura 4.12 mostra o impacto direto da MP 579 sobre as tarifas de energia elétrica, e compara estas tarifas com a de outras fontes de energia, pode-se perceber que 
a MP 579 foi um estimulo à eletrificação, e isto a longo prazo não se intensificará porque as tarifas de energia elétrica começaram a ser reajustadas em 2014 e deverão sofrer reajustes significativos ao longo de 2015 , principalmente pelo acionamento do parque termoelétrico e da maneira que esta forma de energia foi contratada ${ }^{52}$.

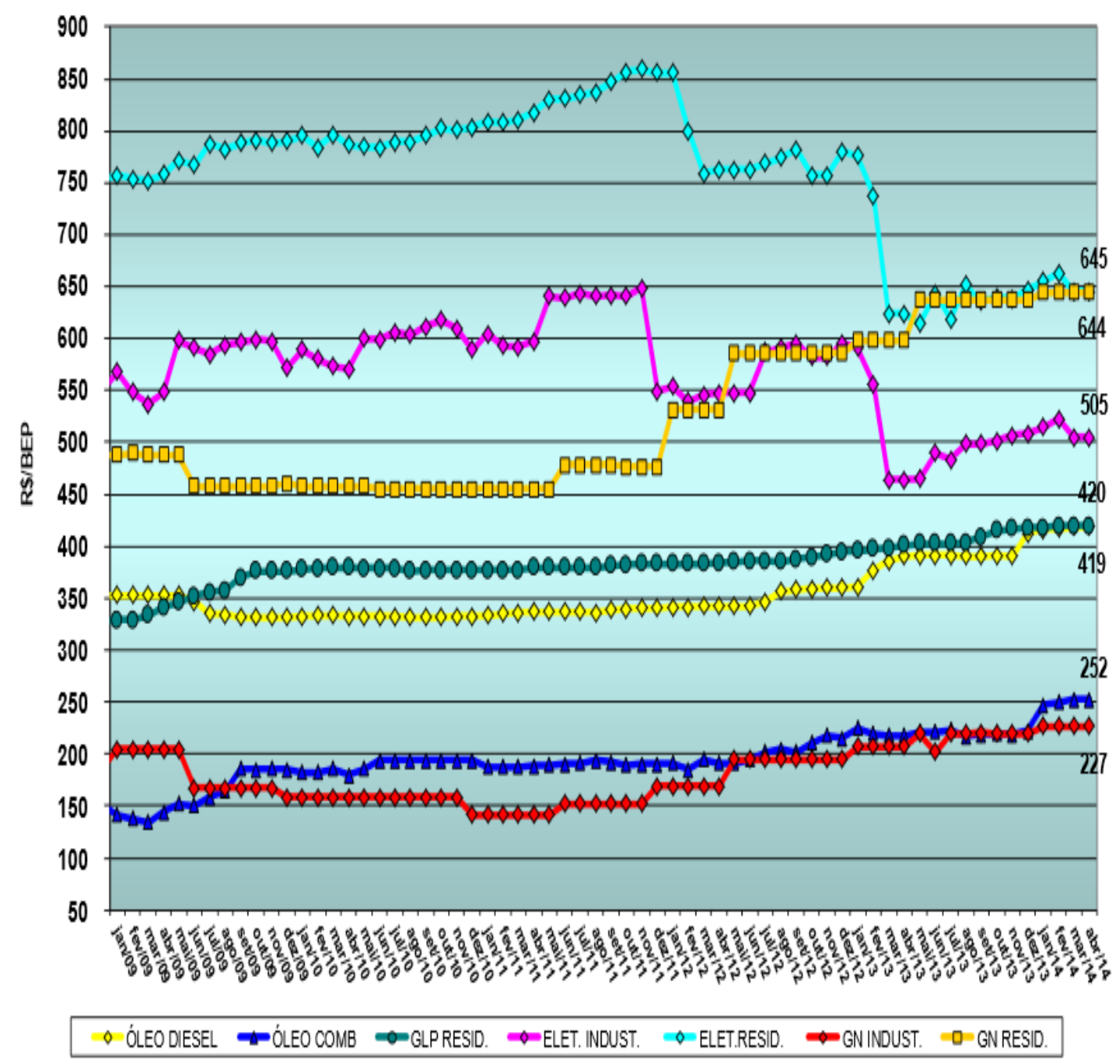

Figura 4.12 - Mercados residencial, comercial e industrial: GLP, óleos diesel e combustível, gás natural, energia elétrica industrial e residencial $(\mathrm{R} \$ / \mathbf{b e p})$

Obs.: Preços de gás natural comgás (SP).

Fonte: Ministério de Minas e Energia - Relatório do Mercado de Derivados do Petróleo (jun 2014)

\footnotetext{
52 A matriz de geração elétrica brasileira é de natureza mista, com presença marcante de fontes renováveis, e, consequentemente com grande peso de fontes de energia intermitentes. O problema com este tipo de geração é que a base intermitente necessita de um backup, no caso brasileiro termoelétrico, contrato para operar como backup algumas destas usinas tem preços de despacho cerca de 3 vezes maiores do que de uma hidroelétrica convencional. Caso a base fosse termoelétrica o acionamento seria menos dispendioso, assim como a operação do sistema em situações de condições hidrológicas desfavoráveis como as de 2012 e 2013.
} 
Foi notável a tendência de eletrificação nos setores residenciais, assim como no setor comercial, o impacto da redução das tarifas foi mais imediato, porque a substituição dos equipamentos é mais simples e requer investimentos que não comprometem o orçamento destas famílias e estabelecimentos a longo prazo.

As Figura 4.13 e Figura 4.14 - Consumo de energia pelas famílias em 2012mostram o crescimento no consumo de energia pelas famílias nos anos de 2011 e 2012, respectivamente, nota-se que o aumento de consumo de energia se manteve, mas a eletrificação foi maior no ano de 2012, em detrimento do aumento do consumo de outras fontes, como o gás natural, que teve aumento no consumo em ambos os anos, mas maior em 2011 quando as tarifas do gás natural eram mais atrativas que as de energia elétrica.

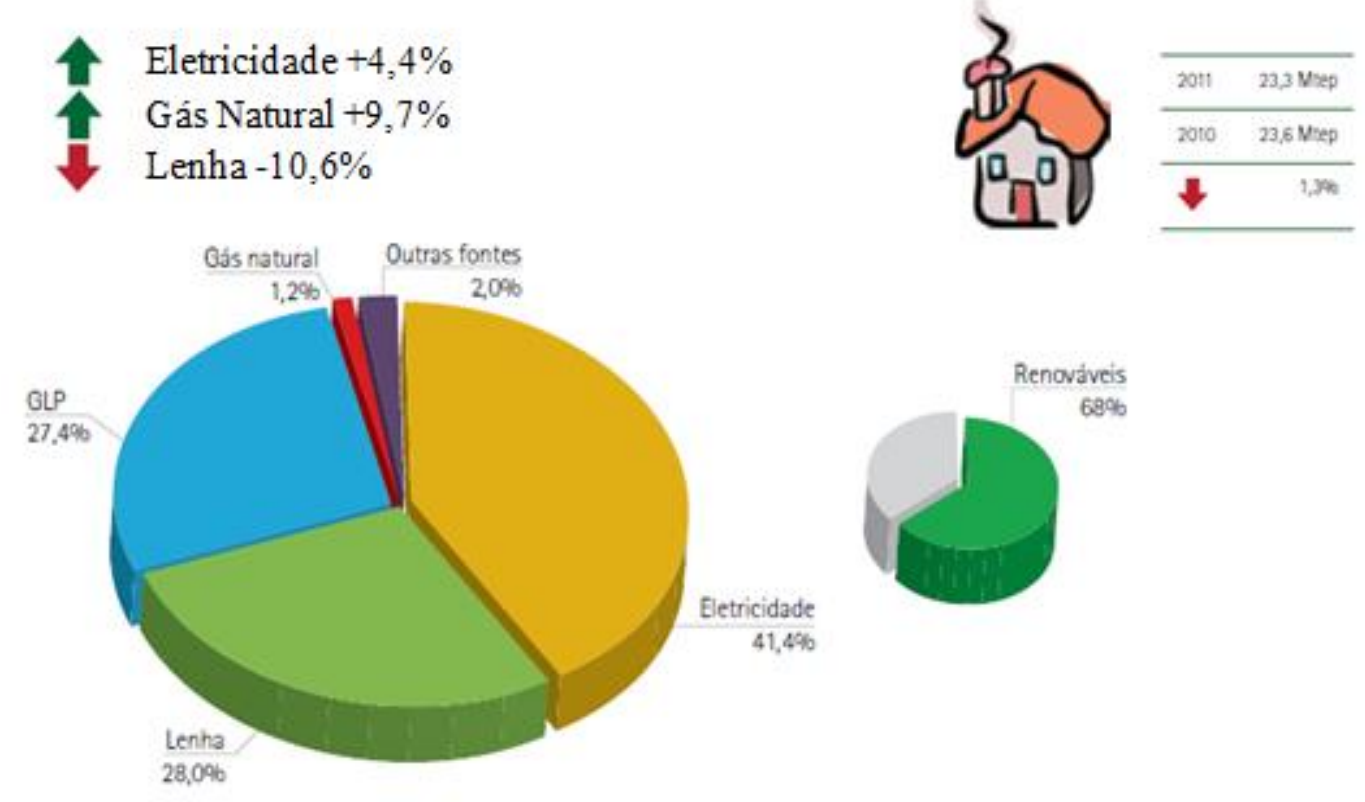

Figura 4.13 - Consumo de energia pelas famílias em 2011

Fonte: MME,2012 
Eletricidade $+5,1 \%$

Gás Natural $+5,6 \%$ (aumento da oferta)

Lenha $-0,5 \%$

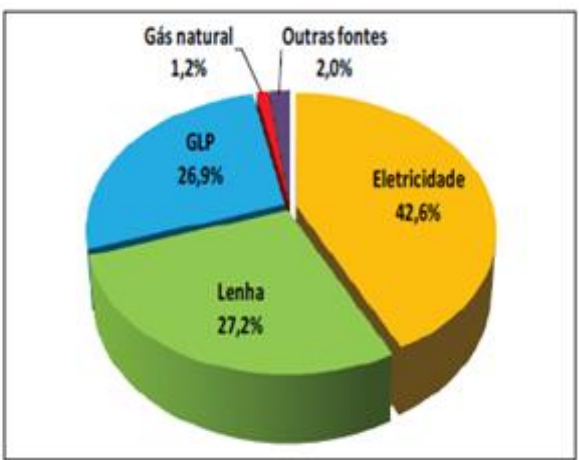

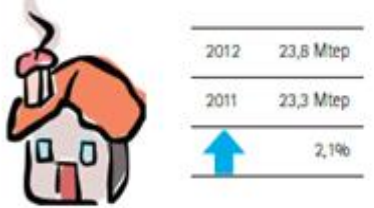

Renováveis $65 \%$

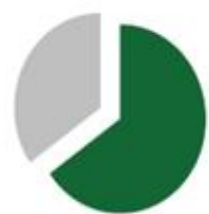

Figura 4.14 - Consumo de energia pelas famílias em 2012

Fonte: MME,2013

De forma análoga, as Figura 4.15 e Figura 4.16 apresentam o consumo de energia no setor industrial, em 2011 e 2012, respectivamente, mesmo o crescimento na energia elétrica ter sido discreto em 2012, a comparação com o consumo de 2011 mostra como a MP 579 impactou o uso de outras fontes, o consumo de gás natural que apresentou alta de $8 \%$ em 2011, teve queda de 1,6\% em 2012.

Gás Natural $+8 \%$

Oleo Combustivel $-10,9 \%$
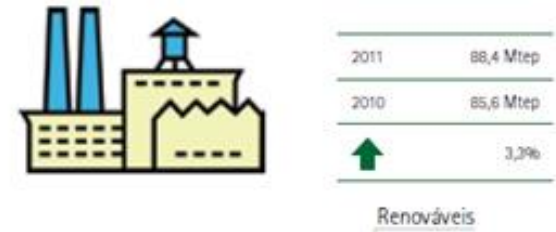

Outras fontes

Renováveis
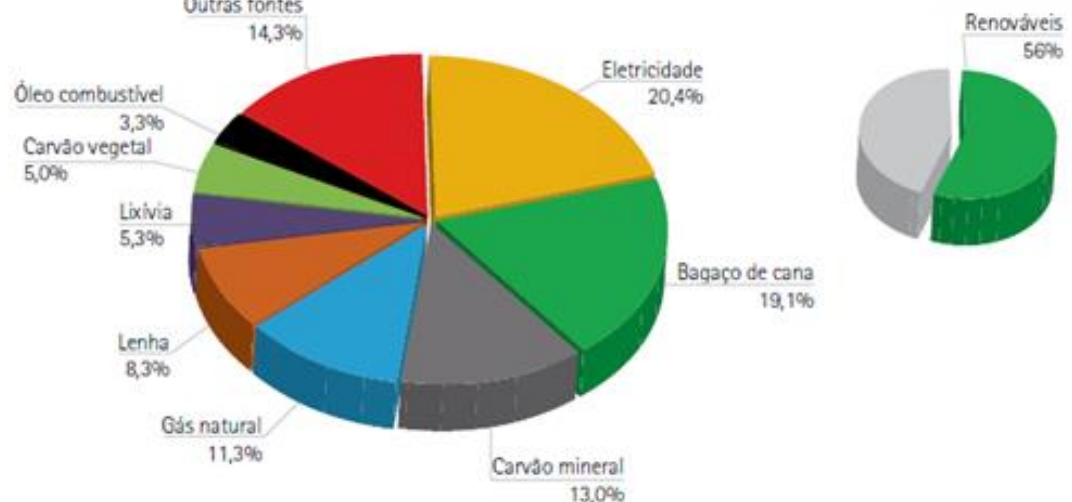

Figura 4.15 - Consumo de energia pelo setor industrial em 2011

Fonte: MME, 2013 

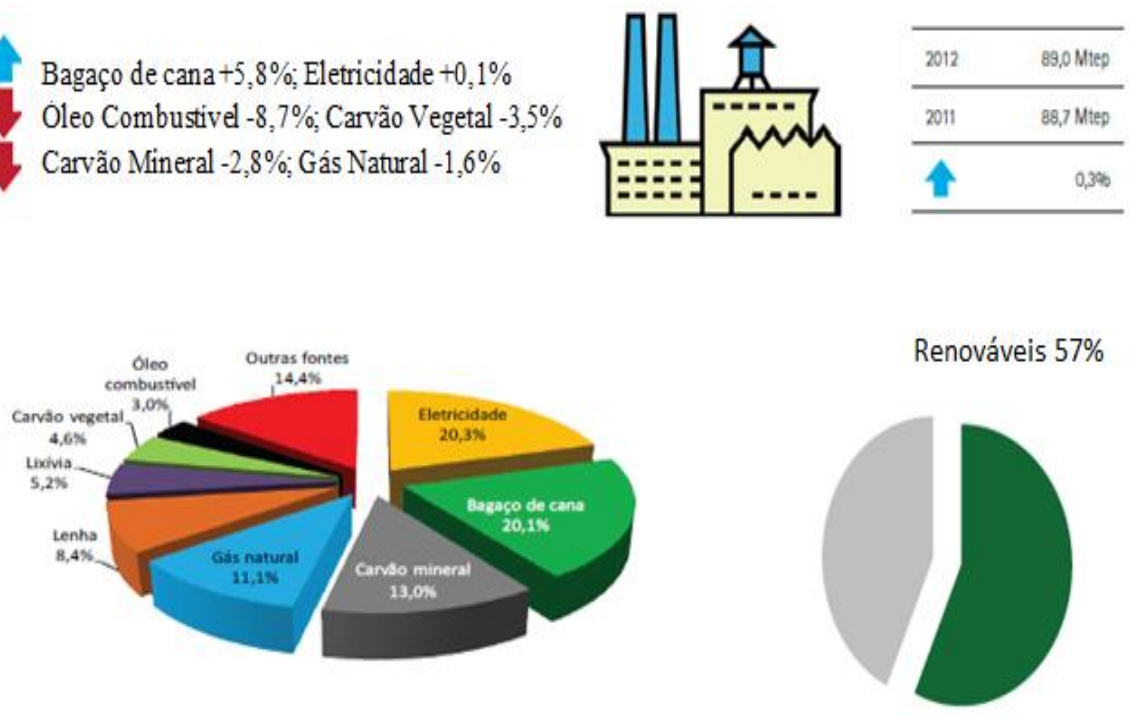

\section{Figura 4.16 - Consumo de energia pelo setor industrial em 2012}

Fonte: MME, 2013

Enquanto o consumo de gás natural pela indústria sofreu um decréscimo, houve um expressivo aumento de $86,3 \%$ na geração térmica a gás natural (incluindo autoprodutores e usinas de serviço público). Em 2012 o gás natural destinado à geração de energia elétrica atingiu 27,6 milhões $\mathrm{m}^{3} / \mathrm{dia}$, o que representa um aumento de $75,7 \%$ ante 2011. (BEN, 2013).

O acionamento térmico foi a solução do governo frente ao crescimento da demanda e às restrições na oferta de energia, em razão do nível baixo dos reservatórios das hidrelétricas, faltou referência a programas de eficiência. A energia economizada com projetos de eficiência pode equivaler à entrada de uma nova usina no sistema, só que sem os impactos ambientais.

Dada a essencialidade do serviço, a redução nas tarifas de energia é muito bem vinda para todos os consumidores, não há como negar o benefício social de tarifas mais acessíveis, no entanto as tarifas devem refletir o ponto de equilíbrio econômico, porque caso contrário, na prática a manutenção da modicidade tarifária torna-se insustentável e em pouco tempo os preços das tarifas aumentarão.

De fato, as medidas governamentais empreendidas entre 2012 e 2014, dentre elas a MP 579, tiveram grande impacto no uso da energia. Intensificou-se a tendência à eletrificação no setor residencial e alterou de forma significativa o consumo de gás natural 
na indústria, este consumo vinha crescendo, principalmente porque as indústrias estavam substituindo combustíveis como óleo combustível e lenha por gás natural. A diminuição da oferta e elevação das tarifas de gás natural, além do próprio recuo industrial frente à crise econômica de 2013 também foram responsáveis pela diminuição do consumo deste insumo pelo setor industrial.

Por uma conjunção de fatores, foi necessário o acionamento térmico para suprir a demanda por energia elétrica, faltou integração e melhor uso das políticas públicas. Programas de eficiência devem ser mais significativos na implementação de medidas que visem acessibilidade e produtividade.

\subsection{Considerações finais do capítulo e proposição de um novo modelo de planejamento para o mercado de gás natural}

Gonzales (2014) aponta uma série de mudanças necessárias nas considerações de oferta e demanda, a fim de se incentivar o mercado de gás, principalmente na geração termelétrica, que deve seguir um modelo diferente de despacho, onde haja maior participação de gás doméstico de maneira a incentivar investimentos em infraestrutura.

Enxergando na crise atual do setor elétrico oportunidades para o desenvolvimento de novas infraestruturas em estocagem e transporte, Gonzales (2014) apoia a compatibilização dos leilões do setor de gás e do setor elétrico, conforme já foi salientado no item 4.4. . Camarota (2014) compartilha da opinião de que há uma necessidade de compatibilização entre os leilões de ambos os setores e também aponta para a necessidade de maior diálogo entre os agentes, além de regras e prazos mais flexíveis para a inclusão de provocações por terceiros.

Camarota (2014) aponta o pionerismo do PEMAT como um benefício do planejamento setorial, porém reforça a necessidade de se testar o novo processo de outorga de dutos; de se questionar o resultado de extensão proposta de apenas $11 \mathrm{~km} \mathrm{em}$ 10 anos; e, de se integrar o PEMAT, os leilões EPE, e as Rodadas de Licitação ANP

Igualmente, Camarota (2014) salienta que apesar de a EPE e o MME ter disponibilizado espaço para diálogo e troca de informações entre os agentes durante a construção, elaboração e finalização do PEMAT, existe a necessidade de maior tempo para debates/contribuições.

Camarota (2014) aponta o dilema do PEMAT: no resultado diz que a "falta de oferta estruturante capaz de sustentar uma ampliação da malha de transporte" e na 
proposta do PEMAT, tem-se que "O PEMAT é uma ação governamental no sentido de solucionar o problema de coordenação de decisões dos agentes envolvidos na cadeia produtiva do gás natural no Brasil, contribuindo para ancorar as expectativas e motivar as decisões dos agentes econômicos."

Dessa forma, depreende-se a partir do exame crítico do PEMAT e de revisão da literatura, que a a aceitação pura e simples dos resultados inicialmente publicados pelo PEMAT 2022 condena a indústria do gás ao seu confinamento e à falta de escala e competitividade. O PEMAT 2022 abandona a indústria do gás de volta ao seu ciclo vicioso e legitima essa situação como política pública. 


\section{CONCLUSÕES}

Os resultados apresentados no PEMAT 2022 foram reflexo, principalmente, da adoção de condicionantes tendenciosos, além de uma metodologia limitada na etapa do balanço de oferta e demanda. Para a simulação no programa Pipeline Studio é necessária a localização dos pontos de oferta e demanda, ou oferta e entrega, e muitos projetos no sentido de aumento da oferta, que deverão estar concluídos dentro do horizonte decenal, não foram incluídos porque a EPE não possuía a exatidão das informações para incluílos.

As premissas adotadas na etapa de balanço de oferta e demanda de gás natural foram decisivas para o resultado e estiveram muito associadas aos interesses da Petrobrás e à visão do MME sobre a inserção futura do gás natural na matriz energética brasileira, como mostra a análise crítica aqui elaborada.

A coincidência de condições hidrológicas desfavoráveis com o aumento de consumo de energia elétrica e a sinalização econômica equivocada por parte do governo brasileiro, criou um ambiente de geração, onde a necessidade de acionamento térmico está cada vez mais presente. E foi diante desse cenário que o PEMAT 2022 foi elaborado.

A ocasião poderia ter sido vista como uma oportunidade de desafiar os princípios clássicos da política energética nacional, que não prestigiam estratégias mais ousadas de diversificar o uso do gás natural na matriz energética, principalmente na substituição da eletricidade em diversos usos finais, da eletrotermia ao domínio absoluto da força motriz a eletricidades.

Uma tal reviravolta na política energética, exigiria um PEMAT com vieses mais positivos e que promovesse projetos de expansão na malha de transporte e distribuição, de modo a expandir as oportunidades de acesso ao gás pelos consumidores finais, condição essencial para um modelo alternativo de inserção do gás nos setores industriais, transporte, residencial e serviços.

No entanto, com a priorização da demanda termelétrica baseada na infraestrutura existente e nas importações via GNL, não houve necessidade de ampliação da malha, e, caso a metodologia do PEMAT, principalmente no que concerne ao balanço de oferta e demanda, não seja alterada, os próximos estudos apresentarão resultados igualmente modestos.

Vale dizer que, em um sentido puramente analítico, o PEMAT manteve-se coerente e o planejador refutou a tentação de "manipulação dos dados e do método 
complexo de análise”, para justificar obras que não economicamente viáveis, mesmo dentro de um cenário de referência relativamente otimista (no que tange aos parâmetros econômicos escolhidos).

A necessidade da existência de uma demanda concentrada e firme, com ampliações sustentáveis ao longo de todo o período de planejamento, é uma das condições de referência que justificam investimentos em infraestrutura dutoviária. Essa situação fica clara nos resultados obtidos no PEMAT 2022.

Porém, deve-se criticar o planejador que demonstra imobilidade frente a esse quadro. Não faz parte do escopo do estudo estabelecer maneiras alternativas de incentivar a criação desta demanda.

De outra parte, há de se enfatizar um agravante ainda maior na classificação da oferta dada pelo planejador. Embora seja inegável o papel da Petrobrás como agente principal na cadeia de suprimento do gás no Brasil, o PEMAT 2022 praticamente desacreditou outras iniciativas capazes de aumentar a oferta. Em nenhum dos seus cenários, eventuais fontes não convencionais de gás natural são potencialmente incluídas no balanço de oferta e demanda. Como resultado final, o planejador conforta-se em não sustentar projetos baseados em Recursos Contingentes ou Recursos Não Descobertos, pois tais potenciais especulativos não estão em conformidade com as premissas inicias do estudo.

Mas, ao adotar posturas tão conservadoras, vale perguntar ao planejador se o PEMAT 2022 não se afastou de seu objetivo maior, imposto pelos legisladores quando a Lei do Gás foi aprovada, qual seja: “O PEMAT (deve ser) uma ação governamental no sentido de solucionar o problema de coordenação de decisões dos agentes envolvidos na cadeia produtiva do gás natural no Brasil, contribuindo para ancorar as expectativas e motivar as decisões dos agentes econômicos".

O PEMAT é um plano determinativo, o que agrava os resultados apresentados, e o que de certa forma também choca-se com a premissa original, uma vez que, para motivar as decisões dos agentes econômicos, é muito mais adequado que o processo preveja aberturas para abordagens indicativas. Na prática, ao se acompanhar, ainda que com dificuldades no acesso às informações, eventuais mobilizações dos agentes, observam-se propostas de investimento que escapam dos olhares do planejador. Então, que o planejamento possa ser mais interativo, menos centralizado e com algum tipo de combinação entre o "determinativo exclusivo" e o "indicativo puro". 
Diante de tudo isso, é evidente que o PEMAT, por si só, não tem capacidade de solucionar o problema de coordenação de decisões dos agentes envolvidos na cadeia produtiva. Antes de tudo porque essas dificuldades não se encerram apenas na questão da expansão da infraestrutura. Uma série de medidas revela-se necessária, e muitas das ações governamentais são de ordem política e estrutural, para incentivar o desenvolvimento do mercado de gás natural, tanto a produção quanto o consumo.

\subsection{Propostas de avanço no plano de pesquisa}

Moutinho dos Santos et al (2002) apontam que o planejamento da logística do gás em países com mercados gasíferos ainda pouco maduros não deve ter um foco exclusivo em gasodutos.

Tendo como base essa referência, a proposta para estudos posteriores é a de configurar um modelo expandido de planejamento logístico dos gases combustíveis. Partindo-se de uma abordagem estabelecida no que se pode considerar um Planejamento Integrado de Recursos (PIR), a autora estabelece o desafio para uma tese de doutorado de conceber um Planejamento Integrado Logístico, que permita definir as bases para o estudo de um Papel Ampliado dos Gases Combustíveis (incluindo, Gases LP, GNL, GNC E BIOMETANO) na Matriz Energética ${ }^{53}$.

Através de um planejamento mais abrangente, as interfaces entre os mercados e o governo poderão ser mais amplas e estratégicas, para que os mercados se desenvolvam da melhor maneira e que o governo ajude a viabilizar projetos que sejam de interesse nacional, pelas ópticas energética, social e ambiental.

Projeções de oferta futuras de gás natural, biometano e gases LP apontam um crescimento significativo $^{54}$, principalmente pelas descobertas offshore em camadas

\footnotetext{
${ }^{53}$ A literatura que define os fundamentos do PIR é abundante (vide, por exemplo, Udaeta (1997) ou Wilson e Biewald (2013)). Os Planos Decenais de Energia elaborados pela Empresa de Pesquisa Energética (EPE) podem ser considerados como exercícios práticos de PIR, pois incorporam as diferentes formas de energia, envolvem análises de custo mínimo do lado da oferta e opções de gerenciamento da demanda, bem como um processo de tomada de decisão aberto e participativo (através de audiências públicas).

${ }^{54}$ Foram avaliadas as projeções dos seguintes estudos: Empresa de Pesquisa Energética: PEMAT 2022; PDE 2022; PNE 2030. Petrobrás: Plano de Investimentos 2030. Agência Internacional de Energia (IEA): World Energy Outlook 2013. Departamento de informação da energia dos Estados Unidos (EIA): International Energy Outlook. (2013). Todos estes estudos apresentaram crescimento na produção de gás natural, acima da média dos últimos anos para o período, principalmente para o gás associado, o que representa consequente aumento na produção de GLP.
} 
rochosas do pré-sal, com os crescentes volumes de gás associado que se espera produzir; bem como em decorrência das inúmeras iniciativas de aproveitamento de resíduos urbanos e agrícolas para fins energéticos. O desenvolvimento de mercados cativos e difusos de gases combustíveis é uma forma de agregar valor a esses recursos, como demonstraram Croso e Moutinho dos Santos (2014).

A concepção dos elementos teóricos e conceituais para um Planejamento Integrado Logístico dos Gases, ampliando o alcance do planejamento para os gases combustíveis, no qual o PEMAT seria apenas um de seus componentes, pode constituir importante contribuição para os estudos e o planejamento da EPE. A inclusão de diferentes gases: GN, gase LP e Biometano; assim como de diferentes modais para o GN: gasodutos, GNL e GNC, contribui para enriquecer o plano de uma logística integrada gasífera.

A integração dos mercados de gases combustíveis é uma forma de garantir as sinergias do setor, entendendo as diferentes opções mais como complementares do que concorrentes. Ou seja, planejamento logístico integrado revela-se essencial para que os potenciais de oferta e demanda possam realizar-se, com cada solução encontrando seus usos mais eficientes e racionais.

O principal argumento para a extensão do plano de pesquisa para dimensões tão mais amplas e fora do atual acance do PEMAT, é demonstrar (ou, eventualmente, refutar) o quanto é equivocado o pressuposto de que a "indústria do gás é exclusivamente uma indústria de redes". A adoção desse pressuposto desconsidera a rica experiência internacional de casos importantes em que a expansão (pelo menos inicial) da logística do gás natural não se deu através de gasodutos, mas sim através de malhas de distribuição a granel, com o gás natural sendo entregue aos consumidores finais na forma de GNL ou GNC, através modais distintos dos gasodutos; ou através da cadeia logística dos gases LP, que ancoram o crescimento dos mercados de gases combustíveis.

Nessa mesma perspectiva ampliada, há, também, de se considerar o biometano. A incipiência da infraestrutura de maneira geral prejudica o desenvolvimento do aproveitamento do biogás, limitando vários benefícios sociais, como, por exemplo, a possibilidade de ampliação de polos industriais regionais, bem como opções para a descentralização da oferta de gás natural, a qual, via de regra, no caso brasileiro, encontrase restrita às faixas litorâneas.

A concepção dos elementos teóricos e conceituais para um Planejamento Integrado Logístico de Gases, ampliando o alcance do planejamento, envolve a 
participação dos agentes da cadeia produtiva ao longo de todo o processo de planejamento, de forma interativa, e não apenas, em fases finais, para validação de resultados através de audiências públicas. É essencial que a tradição do planejamento logístico dos agentes seja colocada a serviço do planejamento macro governamental. Então, através dessa integração, pode-se, sim, esperar que os resultados do planejamento possam contribuir mais efetivamente para motivar as decisões desses mesmos agentes econômicos.

As premissas adotadas em um Planejamento Integrado Logístico dos Gases não podem estar limitadas aos objetivos de um agente dominante ou produtor majoritário, nem deve converter-se em soluções para problemas imediatos do governo. Como parte de um planejamento, as medidas devem ser contempladas no objetivo de construção do cenário desejado dentro do horizonte decenal, incentivando a inserção do gás natural na matriz energética brasileira dentro das possibilidades e dos interesses de toda a cadeia produtiva do gás natural.

Enquanto governo é necessário em qualquer esforço para uma construção a longo prazo, visando sobretudo a racionalidade no uso dos recursos energéticos do país, há de se reconhecer, a partir da análise crítica do PEMAT 2022, que o governo ainda não foi capaz de apresentar soluções e alternativas que possam levar o PEMAT a ser um instrumento realmente capaz de direcionar os agentes da cadeia produtiva de gás natural brasileira.

A principal meta de um estudo governamental que visa planejar a expansão da infraestrutura, deve ser promover a inserção mais efetiva e eficiente de um recurso na matriz energética. Quando se utiliza o planejamento para selecionar prioritariamente as soluções de mínimo custo, não se pode deixar esperar que tais premissas de estratificação conduzam as resultados desalentadores mostrados no PEMAT 2022. Alternativamente, o planejador pode estratificar as informações de forma a contemplar a maior eficiência energética, o uso mais racional dos recursos naturais na nação, a segurança energética ou outros parâmetros que deveriam ser igualmente caros à política energética. Neste ponto, deve-se compreender que a substituição de tecnologias e de fontes energéticas para determinados usos finais precisa ser contemplada não apenas através de análises que utilizam ortodoxamente as ferramentas de mérito econômico, mas igualmente aqueles olhares que buscam promover outros benefícios sociais. 


\section{Referências Bibliográficas}

ALMEIDA, E. (2010). Regulação da distribuição de gás no Brasil. Rio de Janeiro, RJ, Brasil. Fonte: http://www.ie.ufrj.br/hpp/intranet/pdfs/secao6_regulacao_distribuicao.pdf ANEEL -Agência Nacional de Energia Elétrica. Atlas da Energia Elétrica do Brasil AGÊNCIA NACIONAL DE PETRÓLEO, GÁS NATURAL E BIOCOMBUSTÍVEIS. Indústria brasileira de gás natural: regulação atual e desafios futuros. superintendência de comercialização e movimentação de gás natural - Rio de Janeiro: ANP, 2001.

Análise da regulamentação, da estrutura da indústria e da dinâmica de formação dos preços do gás natural no brasil. Coordenadoria de Defesa da Concorrência e Superintendência de Comercialização e Movimentação de Petróleo, seus Derivados e Gás Natural. Dezembro 2011.

ALMEIDA PRADO JR, Fernando Amaral; SILVA, Ana Lúcia Rodrigues. Sobre reformas e concessões no setor elétrico brasileiro: uma análise crítica. Revista Estratégica, v. 11, n. 2, 2013.

ARAÚJO, Symone; CECCHI, José Cesário. Processo de outorga de gasodutos. In: SEMINÁRIO GÁS NATURAL: a lei do gás e o planejamento de expansão da malha de transporte, 2011, Brasília . Anais. Brasília : MME, 2011.

Disponível em: <http://www.mme.gov.br/spg/menu/Seminario-de-GasNatural/seminario.html>. Acesso em:18 jul. 2012.

ASSOCIAÇÃO BRASILEIRA DAS EMPRESAS DISTRIBUIDORAS DE GÁS

CANALIZADO. Mapa das distribuidoras. (2014). Disponível em: < http://www.abegas.org.br/Site/?cat=27>. Acesso em: jan. 2014

BIEWALD-CEO, Bruce;. "Integrated Resource Planning.” New York, U.S.A. Synapse Energy Economics, 2013.

BIROL, Faith et al. “World energy outlook 2013.” Paris, France: International Energy Agency, 2014. 
BRASIL, M. M. E. “Plano decenal de expansão de energia 2022.” MME (Ministério de Minas e Energia), Empresa de Pesquisa Energética, Rio de Janeiro, 2013. 13

EPE (2014). BRASIL, M. M. E. "Plano de expansão da malha de transporte dutoviária 2013-2022.” MME (Ministério de Minas e Energia), Empresa de Pesquisa Energética, Rio de Janeiro, 2014

BRASIL, Presidência da República do. (2014a). Lei nº 11.909, de 4 de março de 2009. Disponível em: http://www.planalto.gov.br/ccivil_03/_ato2007-2010/2009/lei//11909.htm. Acesso em: dez. 2014.

BRASIL, Presidência da República do. (2014b). Decreto no 7.382, de 2 de dezembro de 2010. Disponível em: http://www.planalto.gov.br/ccivil_03/_ato20072010/2010/Decreto/D7382.htm. Acesso em: dez. 2014.

BRASIL, Presidência da República do. (2014c). Lei n ${ }^{\circ}$ 9.478, de 6 de agosto de 1997. Disponível em: http://www.planalto.gov.br/ccivil_03/leis/19478.htm. Acesso em: dez. 2014.

BRASIL, Presidência da República do. (2014d). Lei no 11.907, de 2 de fevereiro de 2009. Disponível em: http://www.planalto.gov.br/ccivil_03/_ato20072010/2009/Lei/L11907.htm. Acesso em: dez. 2014.

BRASIL, Presidência da República do. (2014e). Lei nº 12.490, de 16 de setembro de 2011. Disponível em: http://www.planalto.gov.br/ccivil_03/_Ato20112014/2011/Lei/L12490.htm. Acesso em: dez. 2014.

BRASIL, Presidência da República do. (2014f). Constituição da República Federativa do Brasil de 1988. Disponível em:

http://www.planalto.gov.br/ccivil_03/constituicao/constituicaocompilado.htm. Acesso em: dez. 2014.

BTG PACTUAL. Brazilian Utilities - Big Themes. News Letter aos acionistas. São Paulo, 12 set. 2012.

CÂMARA DOS DEPUTADOS (2015a). Projeto de Lei 6666, de 2006. Disponível em: http://www.camara.gov.br/proposicoesWeb/fichadetramitacao?idProposicao=343991\&o $\mathrm{rd}=1$. Acesso em: jan. 2015.

CÂMARA DOS DEPUTADOS (2015b). Projeto de Lei 334, de 2007. Disponível em: http://www.camara.gov.br/proposicoesWeb/fichadetramitacao?idProposicao=315641. Acesso em: jan. 2015. 
CÂMARA DOS DEPUTADOS (2014). Projeto de Lei 6673, de 2006. Disponível em: http://www.camara.gov.br/proposicoesWeb/fichadetramitacao?idProposicao=316516. . Acesso em: dez. 2014.

CAMAROTA, P. Gás Natural no Brasil: Novo Modelo Setorial. $15^{\circ}$ Seminário do Gás. 05 de Junho de 2014. Instituto Brasileiro de Petróleo (IBP), Rio de Janeiro, 2014.Disponível em: www.ibp.org.br. Acesso: jan. 2015.

CARVALHO, Leonardo Chmielewski de. Análise jurídica da prorrogação das concessões de serviço público de energia elétrica vincendas em 2015. 2013.

CECCHI, José Cesário. Indústria Brasileira de gás natural: regulação atual e desafios. Rio de Janeiro: ANP, 2001.

COELHO, Julião Silveira. Aperfeiçoamentos regulatórios para o mercado livre, palestra proferida no XIII Encontro Internacional de Energia FIESP, São Paulo, 06 ago. 2012.

CROSO, T. MOUTINHO DOS SANTOS, E. (2014). PEMAT, seus impactos sobre o mercado futuro de gás natural. Anais do Congresso Brasileiro de Planejamento Energetico. CBPE. Florianópolis-SC, 2014.

COSTA, Hirdan Katarina de Medeiros A Regulação do Livre Acesso na Distribuição de Gás Natural Canalizado : o caso de São Paulo. 2006. 232p. Dissertação (Mestrado em Energia) - Programa Interunidades de Pós-Graduação em Energia da Universidade de São Paulo, 2006.

COSTA, H. K. M.; SANTOS, E. M. (2006). O transporte no Projeto de Lei do Gás Disponível em: http://catedradogas.iee.usp.br/download/transporte.pdf. Acesso em: nov. 2013.

DANTAS, Thomas Kefas de Souza. Os limites constitucionais ao exercício de direito de patente e seus reflexos na indústria do petróleo, gás natural e biocombustíveis. 2014. 162 fls. Dissertação (Mestrado em Direito Constitucional) - Universidade Federal do Rio Grande do Norte, Natal, 2014.

DE ALMEIDA PRADO JR, Fernando Amaral; DA SILVA, Ana Lúcia Rodrigues. Sobre reformas e concessões no setor elétrico brasileiro: uma análise crítica. Revista Estratégica, v. 11, n. 2, 2013.

DEMORI, Marcio Bastos. GNL como mecanismo de flexibilização do suprimento de gás natural para geração termelétrica no Brasil. 165p. Dissertação (Mestrado em Energia) - 
Programa Interunidades de Pós-Graduação em Energia da Universidade de São Paulo, São Paulo, 2008.

EUROSTAT. Dados relativos ao ano de 2012. Disponível em: http://ec.europa.eu/eurostat/web/energy/data/main-tables. Acesso: jan. 2013.

EMPRESA DE PESQUISA ENERGÉTICA (EPE). Balanço Energético Nacional (BEN). Disponível em: https://ben.epe.gov.br. Acesso em: nov. 2013. PEMAT 2022 (2014). Disponível em: https://epe.gov.br. Acesso em: nov. 2013.

Lei de Criação da EPE. http://www.epe.gov.br/Downloads/Lei_10.847_15.03.04.pdf. Acesso em: out. 2013.

FIDELIS, Marco Antônio. Classificação de Gasodutos. In: SEMINÁRIO: GÁS NATURAL - A LEI DO GÁS E O PLANEJAMENTO DE EXPANSÃO DA MALHA DE TRANSPORTE, 2011, Brasília. Anais. Disponível em:http://www.mme.gov.br/spg/menu/Seminario-de-Gas-Natural/seminario.html>. Acesso em: 18 jul. 2012.

González, E. Projeção Oferta x Demanda 2014. 15 Seminário do Gás. 05 de Junho de 2014. Instituto Brasileiro de Petróleo (IBP), Rio de Janeiro, 2014.Disponível em: www.ibp.org.br. Acesso: jan. 2015.

http://analiseenergia.blogspot.com.br/2013/10/um-ano-depois-da-mp-579-governoainda.html acessado em: 14/11/2013.

https://ben.epe.gov.br acessado em: 14/11/2013.

http://www.bcb.gov.br/?INDECO acessado em: 27/11/2013.

http://www.em.com.br/app/noticia/economia/2013/09/25/internas_economia,453106/ihs -ve-receita-menor-da-eletrobras-por-mp-579.shtml acessado em: 14/11/2013.

http://www.mme.gov.br/mme/galerias/arquivos/PlanoNacEfiEnergetica.pdf acessado em: $1411 / 2013$ 
http://www.redenergia.com/noticias/agencias-de-risco-avaliam-setor-apos-mp-579/ acessado em: 14/11/2013.

LANDEIRA, Juan Lourenço Fandino. ANÁLISE TÉCNICO-ECONÔMICA SOBRE A VIABILIDADE DE IMPLANTAÇÃO DE SISTEMAS DE GERAÇÃO FOtOVOLTAICA DISTRIBUÍDA NO BRASIL. 2013. Tese de Doutorado. Universidade Federal do Rio de Janeiro.

LOSEKANN, Luciano; DA MEDIDA PROVISÓRIA, Através. Ambiente Energia09/10/2012 MP 579: Prorrogação das concessões e apropriação da renda inframarginal.

MARTITS, Luiz Augusto; GARCIA, Fábio Gallo; AMARAL JÚNIOR, José Bento Carlos. Concessões de termoelétricas no Brasil: investir ou não? Revista Brasileira de Casos de Ensino em Administração, v. 2, n. 2, p. c7, 2012.

MEDEIROS, Alexandre Mollica. Bases metodológicas para a incorporação da variável ambiental no planejamento da expansão termelétrica no Brasil. 2003. Tese de Doutorado. UNIVERSIDADE FEDERAL DO RIO DE JANEIRO.

MELO, Elbia. Fonte eólica de energia: aspectos de inserção, tecnologia e competitividade. estudos avançados, v. 27, n. 77, p. 125-142, 2013.

MOUTINHO DOS SANTOS, E. et. al. Gás Natural: estratégias para uma energia nova no Brasil. São Paulo: Annablume, FAPESP, Petrobrás, 2002.

MOUTINHO DOS SANTOS, E. Capítulo 7: Aspectos técnicos e ambientais da exploração de petróleo. In: Textos-Energia que transforma (Kitta Eitler, Vania Lins, org.). Rio de Janeiro: Fundação Roberto Marinho, 2012, p. 54-71.

MICHAELIS. Dicionário de Língua Portuguesa. Disponível em: http://michaelis.uol.com.br/moderno/portugues/index.php?lingua=portuguesportugues\&palavra=competi\%E7\%E3o. Acesso em: dez. 2014. 
- Dicionário de Língua Portuguesa. Disponível em:http://michaelis.uol.com.br/moderno/portugues/index.php?lingua=portuguesportugues\&palavra=planejamento. Acesso em: dez. 2014.

- Dicionário de Língua Portuguesa. Disponível em:http://michaelis.uol.com.br/moderno/portugues/index.php?lingua=portuguesportugues\&palavra=planejamento. Acesso em: dez. 2014.

MINISTÉRIO DE MINAS E ENERGIA (2014). Boletim mensal de acompanhamento da indústria de gás natural. Secretaria de Petróleo, Gás Natural e Combustíveis Renováveis - Departamento de Gás Natural. Disponível em: http://www.mme.gov.br/spg/menu/publicacoes.html>. Acesso em: jan. 2015.

Balanço Energético Nacional 2013. Disponível em: 〈https://ben.epe.gov.br/>. Acesso em: 26 ago. 2013.

Plano Decenal de Expansão de Energia 2013- 2022. Disponível em: <http://www.mme.gov.br/mme/menu/pde2022.html>. Acesso em: 25 maio 2013.

Plano Decenal de Expansão da Malha de Gasodutos 2013-2022. Disponível em: <http://www.mme.gov.br/mme/galerias/arquivos/noticias/2013/PEMAT_20132022.pdf>. Acesso em: 19 jan. 2014. MME abre consulta pública para o PEMAT 2013-2022. Disponível em: <http://www.mme.gov.br/mme/menu/pemat_2013__2022.html>.

Acesso em: 18 jan. 2014.

—. Plano Nacional de Eficiência Energética. Disponível em: http://www.mme.gov.br/mme/galerias/arquivos/PlanoNacEfiEnergetica.pdf. Acesso em: nov. 2013 
NAIME, Roberto. IMPACTOS SOCIOAMBIENTAIS DE HIDRELÉTRICAS E RESERVATÓRIOS NAS BACIAS HIDROGRÁFICAS BRASILEIRAS. INFORMATIVO TÉCNICO DO SEMI-ÁRIDO ISSN 2317-305X, v. 4, n. 1, 2011.

PINTO, R. (2014). Tarifação na malha de gasodutos de transporte no Brasil: Evolução e Perspectivas. São Paulo: PPGE - Insituto de Energia e Ambiente. Universidade de São Paulo.

PIOTO, Marcelo Senna Valle. Os bens reversíveis e a remuneração das transmissoras de energia elétrica. 2013.

RECHELO NETO, Carlos Alberto. GNL para suprimento interno e exportação versus gasodutos: oportunidades, ameaças e mitos. Dissertação de Mestrado. Universidade de São Paulo, São Paulo, 2005.

REIS, Lineu Belico dos. Geração de energia elétrica: tecnologia, inserção ambiental, planejamento, operação e análise de viabilidade 3ed.. Barueri, SP: Manole, 2003.

SANTANA, Rodrigo; Evolução das tarifas de Energia- um olhar de 10 anos, palestra proferida no XIII Encontro Internacional de Energia FIESP, São Paulo, 06 ago. 2012.

UDAETA, Miguel Edgar Morales. Planejamento Integrado de Recursos EnergéticosPIR-para o setor elétrico (pensando o desenvolvimento sustentável). 1997. Tese de Doutorado. Universidade de São Paulo.

U.S., E. I. A. “Annual Energy Outlook”. EIA (Energy Information Administration). United States, 2013.

Michaelis, Dicionário de Língua Portuguesa. Disponível em: http://michaelis.uol.com.br/moderno/portugues/index.php?lingua=portuguesportugues\&palavra=competi\%E7\%E3o. Acesso em: dez. 2014. 
http://michaelis.uol.com.br/moderno/portugues/index.php?lingua=portugues-

portugues\&palavra=planejamento

DANTAS, Thomas Kefas de Souza. Os limites constitucionais ao exercício de direito de patente e seus reflexos na indústria do petróleo, gás natural e biocombustíveis. 2014. 162 fls.

Dissertação (Mestrado em Direito Constitucional) - Universidade Federal do Rio Grande do Norte, Natal, 2014.

Costa e Santos (2006, p. 04)

Lei de Criação da EPE. http://www.epe.gov.br/Downloads/Lei_10.847_15.03.04.pdf

O problema de coordenação de decisões de agentes de uma cadeia produtiva é frequentemente chamado de "paradoxo do ovo e da

galinha", sobretudo, na literatura especializada em inglês (chicken and egg dilemma). Vide, por exemplo, Pritchard (2006) e

Reynolds e Kolodziej (2009) para o uso deste conceito aplicado à industria do gás natural. 